INSTITUTO DE FÍSICA, INSTITUTO DE QUÍMICA, INSTITUTO DE BIOCIÊNCIAS, FACULDADE DE EDUCAÇÃO

\author{
DANILO CARDOSO
}

\title{
Mídia, Ciência e Ensino: Problematizações na formação inicial de Professores de Física
}




\section{UNIVERSIDADE DE SÃO PAULO}

INSTITUTO DE FÍSICA, INSTITUTO DE QUÍMICA, INSTITUTO DE BIOCIÊNCIAS, FACULDADE DE EDUCAÇÃO

\section{Mídia, Ciência e Ensino: Problematizações na formação inicial de Professores de Física}

\begin{abstract}
TESE DE DOUTORADO APRESENTADA AO InstituTO DE FÍsicA, AO INSTITUTO DE QUÍMICA, AO INSTITUTO DE BIOCIÊNCIAS E À FACULDADE DE EDUCAÇ̃̃o DA UNIVERSIDADE DE SÃo PAULO, PARA A OBTENÇÃO DO TÍTULO DE DOUTOR EM ENSINO DE CIÊNCIAS

ÁREA DE CONCENTRAÇÃO: ENSINO DE FÍsICA
\end{abstract}

ORIENTADOR: PROF. DR. IVÃ GURGEL 
Autorizo a reprodução e divulgação total ou parcial deste trabalho, por qualquer meio convencional ou eletrônico, para fins de estudo e pesquisa, desde que citada a fonte.

\section{FICHA CATALOGRÁFICA \\ Preparada pelo Serviço de Biblioteca e Informação do Instituto de Física da Universidade de São Paulo}

Luiz, Danilo Cardoso Rodrigues

Mídia, ciência e ensino: problematizações na formação inicial de professores de física. São Paulo, 2019.

Tese (Doutorado) - Universidade de São Paulo. Faculdade de Educação, Instituto de Física, Instituto de Química e Instituto de Biociências.

Orientador: Prof. Dr. Ivã Gurgel

Área de Concentração: Ensino de Física.

Unitermos: 1. Física - Estudo e ensino; 2. Mídia; 3. Ciência; 4. Ensino de ciências.

USP/IF/SBI-059/2019 
Nome: CARDOSO, Danilo

Título: Mídia, Ciência e Ensino: Problematizações na formação inicial de Professores de Física

Tese apresentada ao Instituto de Física, ao Instituto de Química, ao Instituto de Biociências e à Faculdade de Educação da Universidade de São Paulo para obtenção do título de doutor em Ensino de Ciências

Área de concentração: Ensino de Física

Aprovado em:

Banca examinadora

Prof.

Dr. Instituição:

Julgamento: Assinatura:

Prof.

Dr. Instituição:

Julgamento: Assinatura:

Prof. Dr. Instituição:

Julgamento: Assinatura: 
Prof. Dr.

Instituição:

Julgamento:

Assinatura:

Prof. Dr.

Instituição:

Julgamento:

Assinatura: 
Filhos . . Filhos?

Melhor não tê-los!

Mas se não os temos

Como sabê-lo?

Se não os temos

Que de consulta

Quanto silêncio

Como os queremos!

Banho de mar

Diz que é um porrete...

Cônjuge voa

Transpõe o espaço

Engole água

Fica salgada

Se iodifica

Depois, que boa

Que morenaço

Que a esposa fica!

Resultado: filho.

E então começa

A aporrinhação:

Cocô está branco

Cocô está preto

Bebe amoníaco

Comeu botão.

Filhos? Filhos

Melhor não tê-los

Noites de insônia

Cãs prematuras

Prantos convulsos

Meu Deus, salvai-o!

Filhos são o demo

Melhor não tê-los . . .

Mas se não os temos

Como sabê-los?

Como saber

Que macieza

Nos seus cabelos

Que cheiro morno

Na sua carne

Que gosto doce

Na sua boca!

Chupam gilete

Bebem xampu

Ateiam fogo

No quarteirão

Porém que coisa

Que coisa louca

Que coisa linda

Que os filhos são!

Vinicius de Moraes
À Alice. Pequeno ser, quase não distorce o espaço-tempo, mas faz confusão no ventre de sua mãe, minha amada companheira. À Alice, pequeno ser, que ainda nem nasceu, mas já arrebata meu coração. 


\section{AGRADECIMENTOS}

Agradeço profundamente ao querido professor e orientador, Ivã Gurgel. Já se passaram quase dez anos desde que o conheci, quando fui seu aluno na primeira turma de licenciatura na qual ele ministrou a disciplina Elementos e Estratégias para o Ensino de Física, na USP. Desde então minha admiração e profundo respeito ao Ivã só aumentou. Tê-lo conhecido e tido o privilégio de trabalhar com ele certamente foi uma das coisas pelas quais eu mais agradeço às conspirações do universo e aos acasos da vida.

Agradeço aos colegas e, sobretudo, aos futuros professores com quem tive o privilégio de trabalhar no Instituto Federal de São Paulo.

Agradeço aos novos e velhos colegas do grupo TeHCo: André, Helton, Alex, Alexandre, Heráclio, Marcia, Gabriela (Pi), Sofia, Carlos, Felipe, Barbra, Renan, Artur, Felipe, Raquel, Ivã.

Agradeço à Flávia, Sofia e André, pelos trabalhos desenvolvidos em conjunto e pela mais sincera amizade.

Agradeço às Professoras Alice Pierson e Maria Regina Kawamura pelas críticas e sugestões no exame de qualificação desta tese.

Agradeço à minha família. Ao meu pai e minha mãe, José e Laureci, que sempre me incentivaram a fazer o que me realizasse, independente das minhas escolhas. À minha esposa, Marília. Futura bióloga, amante da natureza e dos animais, em particular deste ser que propõe esta tese.

Agradeço à CAPES pela bolsa concedida, sem a qual eu não teria condições materiais para desenvolver esta pesquisa. Agradeço, sobretudo, aos trabalhadores e trabalhadoras brasileiras que, por meio de impostos, possibilitam políticas de investimento em pesquisa no Brasil. Espero, sinceramente, que o investimento empreendido em minha formação possa ser revertido aos interesses públicos, em busca de um mundo mais justo. 


\section{RESUMO}

Há décadas as pesquisas em ensino de ciências têm indicado que a aprendizagem do conhecimento científico não deve ser considerada um fim em si mesmo. Assim, uma importante questão aos pesquisadores e educadores em ciências é a seguinte: Por que ensinar ciências em nossa atual sociedade? Defendemos que as possíveis respostas a esta questão ampla devem considerar os problemas emergentes do mundo. Dentre essas questões, consideramos que a sociedade contemporânea é marcada pela mídia. É latente seu papel tanto como meio de acesso aos acontecimentos do mundo, quanto para as relações interpessoais. O fenômeno das Fakes News ainda não deixa dúvidas sobre o impacto da mídia na política mundial. Este contexto torna fundamental que a mídia seja problematizada como parte da formação na educação básica. Esta tese busca compreensões sobre as possibilidades de aproximação entre perspectivas da educação para as mídias e o ensino de ciências, fundamentada na literatura destas áreas e em perspectivas freireanas. A literatura indica que a formação de professores é condição sine qua non para que este anseio por problematizar a mídia no ensino de ciências possa ser concretizado. Esta tese analisa a inserção dessas perspectivas na formação inicial de professores de física. Analisamos, a partir da metodologia da Análise Textual Discursiva, materiais desenvolvidos por licenciandos de duas disciplinas do curso de licenciatura em física do Instituto Federal de São Paulo. Uma das disciplinas era introdutória, para alunos do segundo semestre, e versava sobre a divulgação científica de maneira mais ampla, tendo foco na mídia em parte dela. A outra disciplina, focada exclusivamente na busca por aproximar questões sobre a mídia e o ensino de ciências, foi oferecida para licenciandos do quinto e sétimo semestres e envolveu estágio supervisionado. Os dados de ambas disciplinas foram organizados em três eixos: Mídia, Ciência e Ensino. Em cada um desses eixos foram propostas categorias a priori. A partir desta categorização e da impregnação com os dados, propusemos subcategorias a posteirori, que indicam de maneira mais precisa as particularidades dos dados analisados. Nossa análise indicou, dentre outros resultados, que os licenciandos desenvolveram análises críticas de materiais da mídia e que a inserção desses materiais em aulas de física possibilitou abordagens contextualizadas da ciência. Contudo, os resultados também demonstram obstáculos à proposição e implementação de atividades que buscassem uma apropriação crítica e propositiva da mídia em aulas de física. Estes obstáculos são interpretados como fruto de tensões entre a busca por implementar novas perspectivas educacionais e as expectativas dos licenciandos e de outros agentes, tais como supervisores de estágio, com relação ao ensino da física, além das tensões geradas pelas condições concretas a que estão submetidos prfessores, licenciandos e alunos.

Palavras-Chave: Mídia. Ensino de Ciência. Formação de Professores. 


\section{ABSTRACT \\ Title: Media, Science and Teaching: Problematization in the physics teacher training course}

For decades the research in science education has indicated that learning scientific knowledge should not be considered an end in itself. Thus, an important question for science researchers and educators is: Why teach science? We argue that the possible answers to this open question should consider the problems of the world. Among these issues, we consider that contemporary society is pronounced by the media. Its role is latent both as a means of access to world events and interpersonal relations. The Fakes News still leaves no doubt about the impact of the media on political world. This context makes it fundamental for the media to be problematized as part of educational purposes. This thesis intent to understand the possibilities of approximation between perspectives of media education and science education, founded on the literature of these areas and on Freire's perspectives. We analyzed, using the Discursive Textual Analysis methodology, materials developed by undergraduates from two disciplines of the physics teacher training course at the Federal Institute of São Paulo. One of the disciplines was introductory, for second semester students, and was about science popularization, focusing on the media in part of them. The other discipline, focused exclusively on seeking to bring media and science education closer together, was offered to undergraduate fifth and seventh graders and involved supervised internship. Data from both disciplines were organized in three axes: Media, Science and Teaching. In each of these axes, a priori categories were proposed. From this categorization and the impregnation with the data, we proposed subcategories to posteirori, which indicate more precisely the particularities of the analyzed data. Our analysis indicated, among other results, that undergraduates developed critical analyzes of media materials and that the insertion of these materials into physics classes enabled contextualized approaches to science. However, the results also show obstacles to the proposition and implementation of activities that seek a critical and purposeful appropriation of the media in physics classes. These obstacles are interpreted as the result of tensions between the search to implement new educational perspectives and the expectations of undergraduates and other agents, such as internship supervisors, regarding the teaching of physics, in addition to the tensions generated by the concrete conditions to which they are subjected.

Keywords: Media. Scince Education. Teacher Training. 


\section{Sumário}

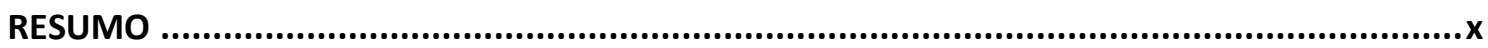

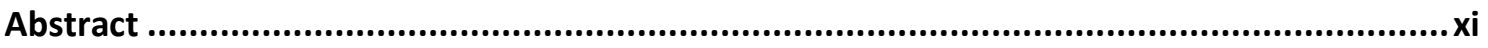

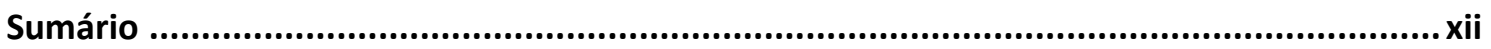

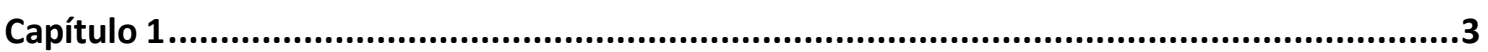

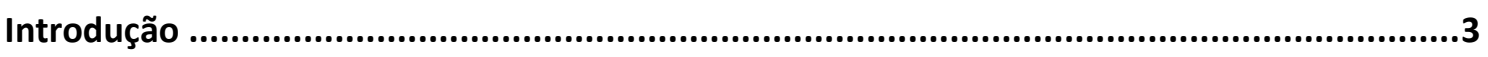

1.1 Alfabetização Científica: objetivos e perspectivas da educação em ciências ..................... 4

1.2 Convergindo para uma questão de pesquisa ................................................................. 20

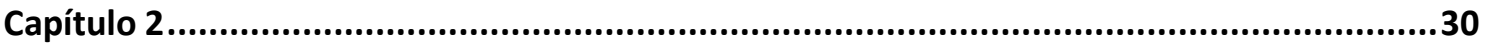

Epistemologia freireana e o sentido da educação ..............................................................30

2.1 Construção e apreensão de conhecimento: diálogo como motor de ambos os processos

2.2 Comunicação e diálogo: olhando para a Mídia a partir de Paulo Freire........................... 42

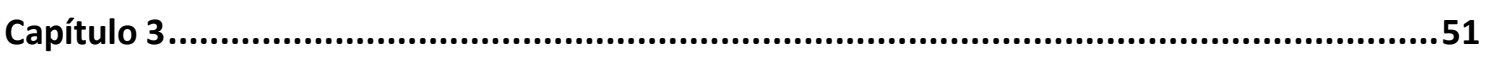

Mídia e Educação: interseç̧ões e desdobramentos para o ensino de ciências.......................51

3.1 Propaganda política e manipulação: uma visão militante de Noam Chomsky ...................53

3.2 FAKE NEWS: um problema da sociedade contemporânea .............................................. 58

3.3 Educação e Comunicação: Perspectivas da “Educação para as Mídias”.............................. 76

3.4 Educação para as Mídias e o Ensino de Ciências ................................................................. 86

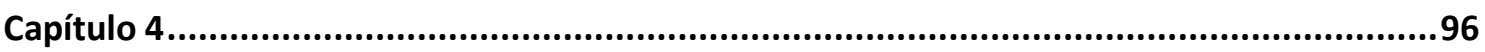

Intermezzo: Análise de textos jornalísticos publicados no contexto das observações do

Eclipse Solar Total de 1919...........................................................................................96

4.1 Análise do texto "Lights all askew in the heavens", publicado no jornal The New York

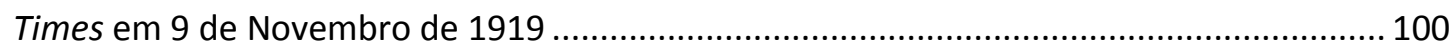

4.2 Análise do texto "Revolution in Science", publicado no jornal The Times London, em 7 de

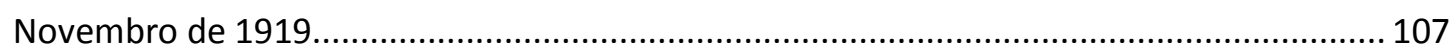

4.3 Análise do texto "Time, Space and Gravitation: The Newtonian System", escrita por Einstein ao Jornal The Times London, em 28 de Novembro de 1919 ................................. 113

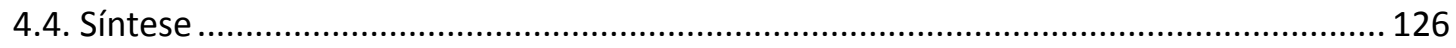

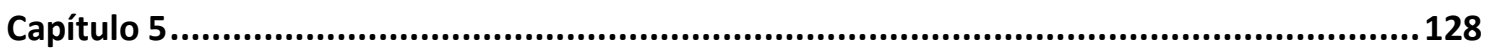

Em busca de parâmetros para a problematização da mídia na educação científica ............128

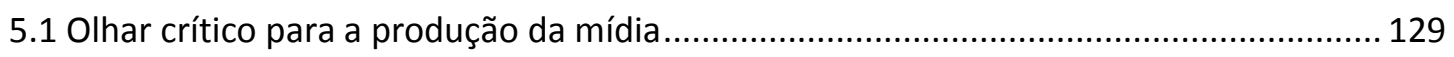

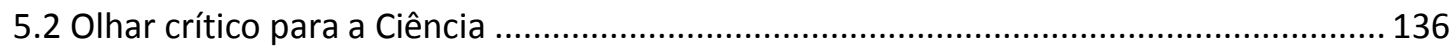




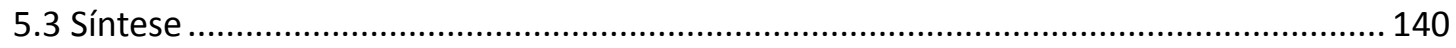

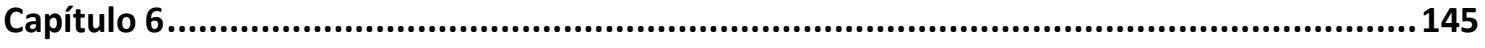

Campo, Corpus e referencial metodológico da pesquisa....................................................145

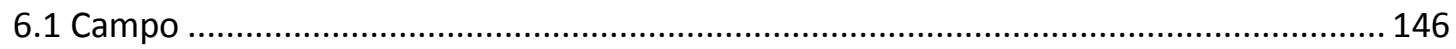

6.1.1 Disciplina Introdução ao ensino e divulgação da Ciência (EDCZ2) ............................ 146

6.1.2 Disciplina Problematizando a Ciência na Mídia ...................................................... 155

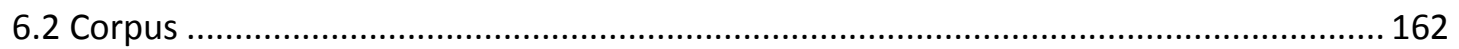

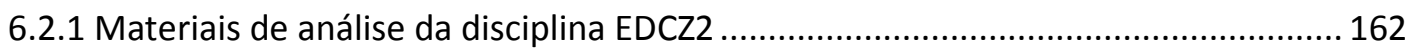

6.2.2 Materiais de Análise da disciplina Problematizando a Ciência na Mídia (PE1)........ 163

6.3 Referencial metodológico da Análise textual discursiva................................................ 164

6.3.1 Desmontagem dos textos: desconstrução e unitarização .......................................... 165

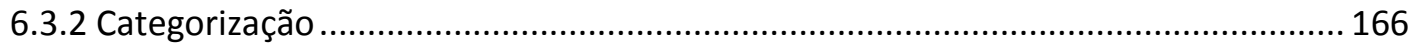

6.3.3 Captando o novo emergente: a construção de metatextos ...................................... 169

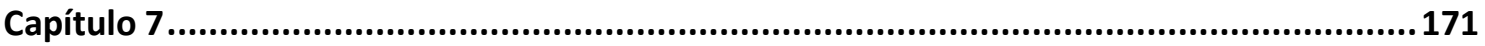

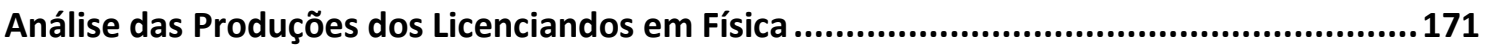

7.1 Produções dos licenciandos da disciplina "Introdução ao Ensino e à Divulgação da

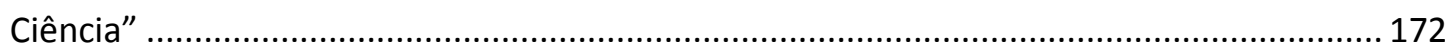

7.1.1 Materiais midiáticos selecionados pelos grupos de EDC ........................................ 172

7.1.2 Categorização: Foco na Mídia .............................................................................. 190

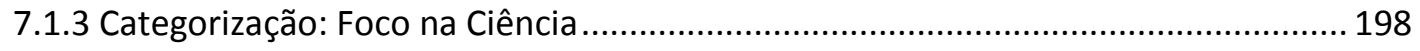

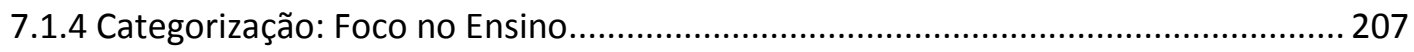

7.1.5 Interpretações a partir das categorizações: construindo um metatexto ................. 215

7.2 Produções dos licenciandos da disciplina "Oficina de Projetos de Ensino 1"................. 218

7.2.1 Materiais midiáticos selecionados pelos licenciandos de PE1 ................................. 219

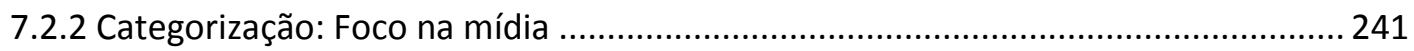

7.2.3 Categorização: Foco na Ciência ............................................................................. 249

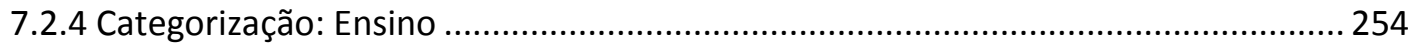

7.2.5 Interpretações a partir das categorizações: construindo um metatexto .................. 267

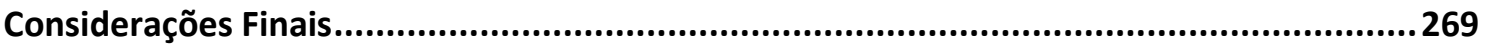

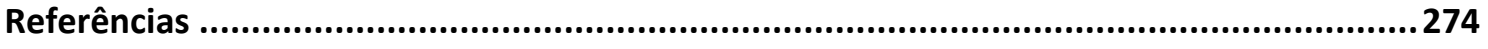

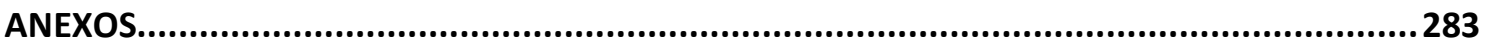




\section{Capítulo 1}

\section{Introdução}

Reforma do ensino médio por medida provisória, proposições de bases curriculares, projetos de lei como o "Escola sem partido" etc., são exemplos de que a educação, as discussões curriculares e as propostas de ensino são um palco de disputas políticas e ideológicas. Em meio a essas disputas, no campo mais restrito do ensino de Física, é essencial problematizarmos uma questão recorrente em discussões curriculares: "Por que ensinar Física em nossa atual sociedade?" Esta é uma questão que nos leva, necessariamente, a uma reflexão sobre fundamentos educacionais, norteada por questões como: que tipo de educação pretendemos? quem queremos formar? queremos formar pessoas para que tipo de sociedade? Essas questões implicam na discussão de quais conteúdos são mais fundamentais - se é que estes existem - para o tipo de formação que pretendemos, e quais abordagens poderão ser mais adequadas para as finalidades pretendidas.

Entendemos que há uma necessidade crescente em justificar o papel do conhecimento científico na formação dos indivíduos, em especial daqueles que não seguirão carreiras científicas ou afins. Quando consideramos as leis brasileiras que regulamentam a Educação (Lei n ${ }^{\circ}$ 9.394, de 20 de dezembro de 1996), em particular as diretrizes para o ensino básico, notamos que a educação não deve ser propedêutica. Isto é, o ensino médio deve - ou deveria - ter a identidade de etapa final de uma formação mais ampla de todos os cidadãos e cidadãs. Então, para além da compreensão do mundo natural através de teorias científicas, espera-se que a formação dos alunos, relacionada à educação científica, seja capaz de promover uma postura crítica e participativa destes em um mundo cada vez mais influenciado pela ciência e tecnologia.

Derek Hodson (2018) aponta que um dos principais objetivos do ensino de ciências é articular "[...] conhecimentos, habilidades, atitudes e valores para lidar com questões do cotidiano que têm uma dimensão de 
ciência e/ou tecnologia e, na vida adulta, desempenhar um papel ativo nas tomadas de decisão e na definição de políticas" (HODSON, 2018, p. 27). Esses objetivos estão ligados, de acordo com o autor, ao que Shen (1975) chama de "letramento científico cívico". Nas últimas décadas, tem sido comum o uso dos termos "letramento científico" ou "Alfabetização Científica" para expressar objetivos gerais da educação em ciências. Considerando a centralidade deste termo nos debates atuais em Educação Científica, apresentaremos, na próxima seção, alguns consensos e dissensos em relação à Alfabetização Científica. A partir de uma discussão geral convergiremos para questões relacionadas à Educação para as Mídias, principal interesse desta tese.

\subsection{Alfabetização Científica: objetivos e perspectivas da educação em ciências}

O termo Alfabetização Científica (scientific literacy) - daqui em diante AC - foi cunhado no final da década de 1950, tendo sido apresentado pela primeira vez no trabalho intitulado Science Literacy: Its Meaning for American Schools, de Paul Hurd (LAUGKSCH, 2000, p. 72). Desde então este termo tem se disseminado e tornou-se um "slogan internacionalmente bem reconhecido, palavra-chave, e objetivo educacional contemporâneo" (LAUGKSCH, 2000, p. 71, tradução nossa), sendo frequentemente encontrado em documentos curriculares (YORE et. al, 2003). De acordo com Douglas Roberts o conceito de Alfabetização Científica tem sido "usado mais e mais extensivamente, em muitos países, para expressar o que deve constituir a educação científica para todos os estudantes" (ROBERTS, 2007, p.729, tradução nossa). Com um uso indiscriminado e amplo, é esperado que não haja uma visão consensual em nossa área sobre o que é ser alfabetizado cientificamente. Para Roberts (2007, p.729) "há um dilúvio de definições para a Alfabetização Científica" e, ainda de acordo com este autor, há apenas um consenso sobre o significado da AC, a saber, que os estudantes não podem ser alfabetizados cientificamente se eles não souberem nenhum conteúdo de ciências (ROBERTS, 2007, p. 735). 
Além da polissemia do termo, a AC é usualmente tida como sinônimo de "entendimento público da ciência", termo mais comum entre os britânicos, e "cultura científica", comum entre os francófonos (LAUGKSCH, 2000; SASSERON \& CARVALHO, 2011). Além disso, no Brasil há uma espécie de disputa entre os termos "letramento" e "alfabetização". De acordo com Lúcia Sasseron e Ana Maria Pessoa de Carvalho (2011), os autores brasileiros usam os termos destacados acima, além do termo "enculturação científica", para demonstrarem, de maneira geral, as mesmas preocupações com o ensino de ciências. Segundo as autoras, todos esses termos designam o objetivo do ensino de ciências de almejar "a formação cidadã dos estudantes para o domínio e uso dos conhecimentos científicos e seus desdobramentos nas mais diferentes esferas de sua vida" (SASSERON \& CARVALHO, 2011, p. 60). Ainda de acordo com as autoras, os pesquisadores nacionais que preferem a expressão "Letramento Científico" justificam sua escolha apoiando-se em duas grandes pesquisadoras da linguística, a saber, Magda Soares e Angela Kleiman. Usaremos nesta tese o termo "Alfabetização Científica", em especial apoiados no entendimento freireano de alfabetização, que aprofundaremos no próximo capítulo.

Décio Auler e Demétrio Delizoicov (2001) defendem a AC como um meio de inserir os estudantes nas questões relacionadas à ciência, tecnologia e sociedade (CTS). Eles apontam duas perspectivas de AC: reduzida e ampliada, defendendo a articulação da segunda. $\mathrm{Na}$ perspectiva reducionista, afirmam os autores, "espera-se que os 'conteúdos operem por si mesmos' ou como um fim em si” (AULER \& DELIZOICOV, 2001, p. 6), enquanto na perspectiva ampliada "os conteúdos são considerados como meios para a compreensão de temas socialmente relevantes" (idem). Os autores baseiam-se em Paulo Freire, especialmente em sua defesa de que alfabetizar, muito mais do que ler palavras, deve propiciar a "leitura do mundo". Nesta direção, Gil Pérez e Peña (2001), recorrendo à ideia de alfabetização multidimensional, de Bybee (1997), apontam que "uma Alfabetização Científica, mesmo incluindo o manejo do vocabulário 
científico, não deve limitar-se a essa definição funcional" (GIL-PÉREZ \& PEÑA, 2001,p. 3, tradução nossa).

Gil Perez e Peña (2001) apontam, também, para a necessidade de superarmos uma educação meramente conteudista, afirmando que "o que a investigação está mostrando é que a compreensão significativa dos conceitos exige superar o reducionismo conceitual e abordar o ensino de ciências como uma atividade, próxima a investigação científica, que integra os aspectos conceituais, procedimentais e axiológicos (GIL-PÉREZ \& PEÑA, 2001,p. 6, tradução nossa).

Sasseron e Carvalho (2011), a partir de uma revisão dos trabalhos em AC, nacionais e internacionais, constataram que diferentes autores listam diversas habilidades como necessárias de serem encontradas entre os alfabetizados cientificamente. As autoras entendem que existe certa convergência entre tais habilidades. A partir disto, propuseram três grandes categorias que englobam todas as habilidades encontradas na literatura. Chamaram essas categorias de "Eixos Estruturantes da Alfabetização Científica”. São eles:

- compreensão básica de termos, conhecimentos e conceitos científicos fundamentais;

- compreensão da natureza das ciências e dos fatores éticos e políticos que circundam sua prática;

- entendimento das relações existentes entre ciência, tecnologia, sociedade e meio-ambiente.

As autoras indicam que "as propostas que surgirem respeitando esses três eixos devem ser capazes de promover o início da Alfabetização Científica" (SASSERON \& CARVALHO, 2011, p. 76).

Ático Chassot (2003), assim como boa parte dos autores que trabalham com a $\mathrm{AC}$, demonstra preocupação em que a educação científica seja voltada às questões com relevância social: 
Amplio mais a importância ou as exigências de uma Alfabetização Científica. Assim como se exige que os alfabetizados em língua materna sejam cidadãs e cidadãos críticos, em oposição, por exemplo, àqueles que Bertolt Brecht classifica como analfabetos políticos, seria desejável que os alfabetizados cientificamente não apenas tivessem facilitada a leitura do mundo em que vivem, mas entendessem as necessidades de transformá-lo - e, preferencialmente, transformá-lo em algo melhor. (CHASSOT, 2003, p. 94)

George DeBoer (2000) afirma que AC é um conceito geral que teve, e continua tendo, uma variedade de significados. Contudo, entende que podemos concluir que a AC "geralmente tem implicado uma compreensão ampla e funcional da ciência para propósitos gerais de educação e não para a preparação para carreiras técnicas e científicas específicas" (DeBOER, 2000, p.594, tradução nossa). Existem, aparentemente, alguns consensos superficiais sobre AC, como o apontado acima. Neste sentido, Yore e colaboradores afirmam que as reformas curriculares ocorridas na década de 1990 na Austrália, Canadá, Nova Zelandia e Reino Unido promoveram uma definição padrão de AC para todos os estudantes como sendo "habilidades e hábitos mentais requeridos para construir entendimento de ciência, para aplicar essas grandes ideias a problemas reais e questões envolvendo ciência, tecnologia, sociedade e ambiente, e para informar e persuadir outras pessoas a agirem com base nessas ideias da ciência" (YORE et al, 2003, p.690, tradução nossa).

De acordo com Isabel Martins (2010), encontramos na literatura relatos de investigações e intervenções voltadas à promoção da alfabetização que a entendem de diferentes maneiras. Além da pluralidade de definições presentes na literatura, pode-se encontrar diferentes maneiras de se compreender ao que a noção de Alfabetização Científica se refere. De acordo com a autora, não é claro se a AC é "objeto de ensino, meta de aprendizagem, referencial para desenvolvimento de currículos, base para a avaliação do conhecimento público da ciência ou como objetivo de pesquisa" (MARTINS, 2010, p. 364). Para DeBoer (2000), muitos autores têm admitido 
que o termo Alfabetização Científica não é mais do que um slogan útil para dar mais e melhor suporte ao ensino de ciências. Para o autor, se isto for verdade, "então falar em Alfabetização Científica é simplesmente falar em educação científica em si” (DeBOER, 2000, p. 587, tradução nossa).

Laugksch (2000) argumenta que existem diferentes fatores que podem influenciar as interpretações sobre AC. Para o autor, esses fatores incluem:

i. Os diferentes grupos de interesse em $\mathrm{AC}$;

ii. Diferentes definições conceituais de AC;

iii. Natureza absoluta ou relativa da AC como um conceito;

iv. Diferentes propósitos para defender a AC;

v. Diferentes maneiras de avaliar a AC;

O autor argumenta que cada fator consiste de diferentes posições e postula que as combinações das diferentes facetas de cada um desses cinco fatores resultam em variadas interpretações e percepções sobre AC (LAUGKSCH, 2000, p. 74). A seguir reproduzimos uma imagem utilizada pelo autor para representar o entendimento sobre AC como sendo tributário de uma dinâmica entre os fatores por ele apontados.

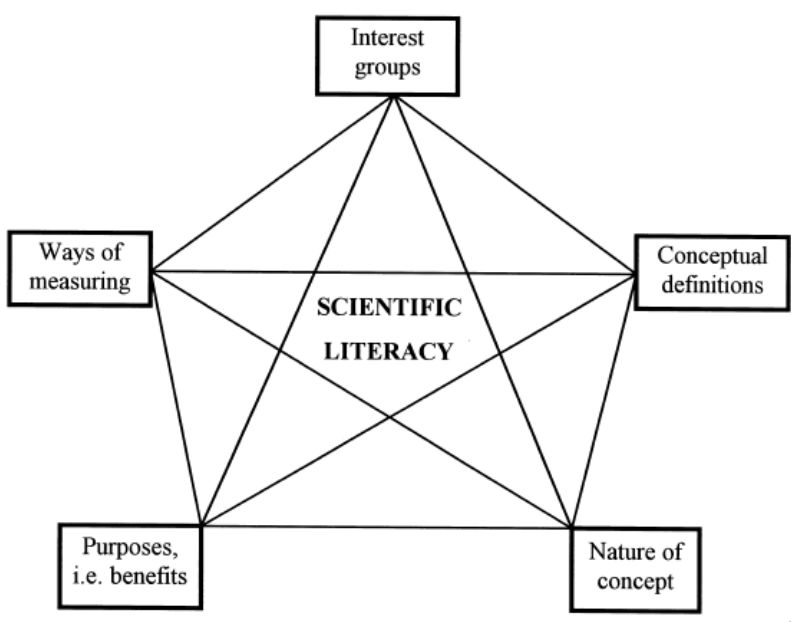

Figura 1 - Fatores que influenciam o entendimento sobre AC, de acordo com Laugksch (2000, p. 74)

O primeiro grupo de interesse que o autor identifica é a comunidade de educação em ciências, que está preocupada com os propósitos, performances e reformas dos sistemas educacionais existentes. Este grupo de interesse está focado na relação entre ensino formal e AC, sobretudo nos 
aspectos curriculares do ensino de ciências. Este grupo é motivado por questões relacionadas aos itens que segue:

- objetivos da educação científica;

- como as habilidades, atitudes e valores pessoais são integrados no currículo de ciências e efetivamente ensinados pelos professores;

- A qualidade e a natureza das fontes de recursos para atingir os objetivos da educação científica de maneira eficiente;

- Processos de avaliação apropriados para estimar até que ponto os objetivos da educação científica são alcançados;

O segundo grupo de interesse identificado pelo autor inclui os cientistas sociais e pesquisadores em opinião pública, preocupados em questões relacionadas às políticas envolvendo ciência e tecnologia, em particular em como os cidadãos apoiam e participam neste tipo de política. Este grupo estaria interessado, de acordo com o autor, em identificar as fontes de informações sobre ciência e tecnologia acessíveis aos cidadãos; em avaliar as bases do conhecimento científico dos cidadãos e suas percepções sobre os limites da ciência; análise das atitudes dos cidadãos com relação à ciência e tecnologia, em geral, e com políticas específicas relacionadas a esta temática.

Outro grupo de interesse identificado pelo autor são aqueles empenhados em educação não formal e informal da ciência, envolvidos na comunicação geral da ciência. Este grupo promoveria atividades educacionais para o público em geral, produzindo notícias ou programas de divulgação científica jornalística a partir de fontes primárias ou secundárias de ciências. Esta comunidade seria composta também por profissionais envolvidos com museus e centros de ciências, zoológicos, jardins botânicos, grupos itinerantes de exposição de atividades científicas, etc. Este grupo de interesse evidencia que a educação, e a educação científica em particular, não é tributária apenas de processos escolares, ou do que podemos chamar 
de "Educação Formal”. A educação se dá, também, em espaços "Não Formais" e "Informais" (TRILLA et al, 2008).

Cada um desses grupos de interesse têm diferentes públicos como audiência. O grupo de educação científica foca, principalmente, na Alfabetização Científica de crianças e adolescentes na escola básica. O grupo de cientistas sociais e sociólogos da ciência focam, sobretudo, na Alfabetização Científica de adultos, isto é, na Alfabetização Científica em esferas que transcendem a escola. O último grupo de interesse foca, de acordo com o autor, na alfabetização de todas as audiências mencionadas acima: crianças, adolescentes e adultos.

Considerando tantos interesses envolvidos em torno de uma temática em comum, ou pelo menos em torno de um termo em comum: Alfabetização Científica, podemos reafirmar a polissemia atribuída à AC. Douglas Roberts (2007) entende que essa diversidade de significados para o conceito de AC na literatura pode ser melhor compreendida se levarmos em conta uma tensão política e intelectual inerente à educação científica. Ele se refere a duas legítimas, potencialmente conflituosas, fontes curriculares: "ciência como assunto em si mesma, e situações em que a ciência pode legitimamente ser vista como desempenhando papel em outras atividades humanas" (ROBERTS, 2007, p.729, tradução nossa). Para este autor, há uma tendência à polarização na literatura sobre $\mathrm{AC}$, entre aqueles que advogam a favor de cada uma dessas duas fontes curriculares. Para representar esta suposta polarização, Roberts (2007) propõe duas visões sobre AC.

A visão I representa a defesa mais "internalista" da ciência, preocupada, sobretudo, com os processos e produtos científicos, designando formas de pensar legitimadas pela ciência como, por exemplo, a habilidade de interpretar gráficos e utilizar formas matemáticas para expressão de conceitos científicos. Neste sentido, podemos entender que o objetivo de ensinar ciências seria tornar o aluno capaz de articular essas características inerentes à ciência para se expressar cientificamente. A visão I "olha para dentro da ciência, para construir o currículo a partir de sua rica e bem 
estabelecida matriz de técnicas e métodos, hábitos de pensamento, e explicações bem testadas sobre os eventos e objetos do mundo natural" (ROBERTS \& BYBEE, 2014, p. 546, tradução nossa).

A visão II, "externalista", está interessada, principalmente, nas possíveis relações que a ciência pode ter com questões de cunho social, que busque a promoção do exercício da cidadania dos sujeitos envolvidos no processo de educação em ciências. A visão II começa "por olhar fora da ciência para construir um currículo que ilumine como a ciência permeia e interage com várias áreas do empreendimento humano e situações da vida das pessoas. Essas questões sociais e de situações de vida individual usualmente incluem considerações políticas, econômicas e éticas" (ROBERTS \& BYBEE, 2014, p. 546). De acordo com Roberts (2007), essa perspectiva mais focada em ciência e sociedade vinha prevalecendo na literatura. Contudo, em revisão mais recente (ROBERTS \& BYBEE, 2014) a conclusão é exatamente contrária, isto é, a visão I tem sido hegemônica nos últimos anos. Para os autores "parece haver um afastamento da visão II em favor da visão I" (ROBERTS \& BYBEE, 2014, p.545). Eles justificam essa conclusão usando como exemplos alguns documentos curriculares estadunidenses. De acordo com os autores, o documento National Science Education Standards, de 1996, fora construído em torno da visão II. Em contrapartida, um documento mais recente, de 2012, A Framework for K-12 Science Education: Pratices, Crosscuting, and Core Ideas sequer menciona o termo Alfabetização Científica como uma ideia central. Além disso, os autores consideram que falta neste documento de 2012 oportunidades para os estudantes entenderem como a aplicação do conhecimento e das práticas científicas têm incidências em questões sociocientíficas, isto é, falta o que os autores estão chamando de uma AC do tipo visão II. Os autores consideram que em partes esse afastamento se deu pelo comitê que fora formado para desenvolver o documento.

Os autores buscam em alguns documentos curriculares internacionais a exemplificação das visões I e II. Como um exemplar de visão I, Roberts e Bybee (2014) selecionam o documento conhecido como Project 2061, 
desenvolvido pela American Association for the Advancement of Science ${ }^{1}$. Neste documento é considerada alfabetizada cientificamente a pessoa que:

- É consciente de que Ciência, Matemática e Tecnologia são empreendimentos interdependentes, com pontos fortes e limitações.

- Compreende conceitos e princípios chaves da ciência.

- É familiar com o mundo natural e reconhece sua diversidade e unidade.

- Usa o conhecimento científico e as formas de pensamento da ciência para propósitos individuais e sociais.

(American Association for the Advancement of Science, 1989 apud ROBERTS \& BYBEE, 2014, p. 546)

Essas características destacadas pelos autores como sendo um exemplo concreto da visão I nos permite inferir que, embora esta abordagem coloque o conhecimento científico em si como o objetivo da educação em ciências, a visão I de AC não valoriza uma apreensão acrítica e propedêutica da ciência. Ou seja, a perspectiva da visão I não é a mesma perspectiva que Auler e Delizoicov (2001) chamaram de "perspectiva reducionista". A perspectiva reducionista é aquela, segundo os autores, que desconsidera a existência de construções subjacentes ao conhecimento científico-tecnológico, tal qual aquela que leva a uma visão de neutralidade da ciência. Nos pontos acima é possível notar uma preocupação em sublinhar a ciência como um conhecimento que tem intersecções com outras formas de conhecer o mundo, além de um interesse em considerar os méritos e limitações do conhecimento científico, e ainda a possibilidade de usar este conhecimento para propósitos individuais ou coletivos, o que no nosso entendimento deixa transparecer a não neutralidade deste conhecimento.

Para exemplificar a visão II, Roberts e Bybee (2014) selecionam o projeto inglês chamado de Twenty First Century Science, que espera que uma pessoa alfabetizada cientificamente seja hábil para:

\footnotetext{
${ }^{1}$ Associação Americana para o Avanço da Ciência.
} 
- Apreciar e entender o impacto da ciência e tecnologia no dia a dia;

- Tomar decisões pessoais informadas sobre questões envolvendo ciência, tais como saúde, alimentação, uso de fontes de energia;

- Ler e entender os pontos essenciais de textos da mídia sobre matérias que envolvem a ciência;

- Refletir criticamente sobre as informações contidas nestes textos de mídia, e (frequentemente mais importante) sobre as informações omitidas nesses textos.

- Participar com confiança em discussões com outras pessoas de questões envolvendo a ciência.

(Twenty First Century Science, 2013 apud ROBERTS \& BYBEE, 2014, p. 547, negrito nosso)

Podemos notar que na visão II o mundo social é tido como referência. Isto é, nesta perspectiva o conhecimento científico seria um meio e não o fim da educação em ciências. Parece-nos necessário, no entanto, enfatizar que o conhecimento científico em si ainda desempenha papel importante neste tipo de educação. Não se trata de priorizar as questões sociais em detrimento de uma compreensão científica do mundo, uma vez que entendemos que tais questões sociais podem ser fundamentadas em conhecimento da ciência. Ou seja, entendemos que uma educação científica interessada em promover leituras críticas do mundo deve, de fato, ter o mundo social como referência, mas sem deixar de lado as características próprias da dinâmica da ciência. Roberts e Bybee (2014) apresentam um arranjo curricular que busca a promoção de ambas as visões igualmente. Segundo os autores, isto tem sido almejado há mais de uma década no Canadá (ROBERTS \& BYBEE, 2014, p. 548). Em documentos que fornecem algumas diretrizes para a educação científica neste país é possível encontrar a definição de AC como sendo uma "combinação de atitudes cientificamente relacionadas, habilidades, e conhecimento que os estudantes necessitam para desenvolverem habilidade para questionar, resolver problemas, e tomar decisões, para tornarem-se aprendizes por toda a vida, e para manter um senso de admiração e curiosidade acerca do mundo que os cerca" 
(Council of Ministers of Education, Canada apud ROBERTS \& BYBEE, 2014, p. 548). De acordo com Roberts e Bybee (2014, p. 548) esta perspectiva canadense tem a expectativa de que o currículo, os materiais instrucionais e os Professores possam prover oportunidades para os alunos aprenderem sobre as relações entre ciência, tecnologia e sociedade ao mesmo tempo em que eles aprendam conteúdos, habilidades e atitudes.

O trabalho de Stephen Norris e Linda Philips (2003) pode ser considerado como estando mais próximo à visão I (ROBERTS \& BYBEE, 2014, 546). Norris e Philips fazem uma distinção entre um sentido fundamental de AC - "ler e escrever quando o assunto é a ciência" - e um sentido derivado de AC - "sendo conhecedor, versado, e educado em ciência" (p.224, tradução nossa). Os autores argumentam que o sentido fundamental é central para a AC, pois ele seria condição necessária para o desenvolvimento de outras habilidades, relacionadas às situações que não são estritamente científicas. Isto é, para que o aluno possa exercer criticamente o pensamento científico para discutir questões sociais é necessário que tenha desenvolvido o sentido fundamental. Graça Carvalho (2009), comentando as categorias de sentido fundamental e sentido derivado da AC propostas por Norris e Phillips (2003), defende que a ciência, tal como a conhecemos, nunca poderia ser o que é se não fosse o texto em que ela assenta e que, portanto, dada a dependência da ciência no texto, uma pessoa que não saiba ler e escrever - complementamos com uma pessoa que não saiba ler e escrever quando o assunto é ciência - estará severamente limitada à aprendizagem em ciências (CARVALHO, 2009, p. 180). Novamente argumentamos que para almejarmos uma formação mais ampla dos estudantes, focando sobretudo em questões relacionadas ao mundo social em que estão inseridos, é necessário que tenhamos o cuidado de considerar características epistemológicas próprias do conhecimento científico. A tese central de Norris e Phillips é que a leitura e escrita não têm uma relação meramente funcional com a ciência, como uma simples ferramenta de transmissão de conhecimento científico. 
A tese que devemos defender é que ler e escrever não reside apenas em uma relação funcional com relação à ciência, como simplesmente ferramentas para o armazenamento e a transmissão da ciência. Em vez disso, o relacionamento é constitutivo, em que a leitura e a escrita são partes constitutivas da ciência. As relações constitutivas definem as necessidades porque os constituintes são elementos essenciais do todo. Remova um constituinte, e o todo vai com ele. Arranque a capa e mantenha o conteúdo, e você ainda tem um livro; Jogue fora o conteúdo e mantenha a capa, e você não tem mais um livro (NORRIS \& PHILLIPS, 2003, p. 226).

Norris e Phillips consideram que são poucos os trabalhos que consideram a AC em seu sentido fundamental. Os autores citam o trabalho de Millar e Osborne (1998) como tendo uma perspectiva próxima ao sentido fundamental de AC, por acreditarem que o "currículo científico deve fornecer conhecimento científico e conhecimento suficiente para permitir que os alunos leiam artigos de jornal simples sobre ciência" (MILLAR \& OSBORNE apud NORRIS \& PHILLIPS, 2003, p. 225). Citam, ainda, uma visão semelhante expressada pelo National Research Council, ao defenderem que "a Alfabetização Científica implica ser capaz de ler com compreensão artigos sobre ciência na imprensa popular" (idem).

A partir de uma revisão da literatura, Norris e Phillips apontam uma variedade de usos para a AC (NORRIS \& PHILLIPS, 2003, p. 225), que organizamos em tópicos de a a $k$ :

a. Conhecimento do conteúdo científico e habilidade em distinguir ciência de não ciência;

b. Compreensão da ciência e suas aplicações;

c. Conhecimento do que vem a ser ciência;

d. Independência no aprendizado de ciência;

e. Habilidade para pensar cientificamente;

f. Habilidade de usar conhecimento científico na solução de problemas; 
g. Conhecimento necessário para participação inteligente em questões sociais relevantes à ciência;

h. Compreensão da Natureza da Ciência, incluindo suas relações com a cultura;

i. Apreciação e conforto com a ciência, incluindo sua beleza e curiosidade;

j. conhecimento dos riscos e benefícios da ciência;

k. Habilidade para pensar criticamente sobre ciência e negociar com especialistas;

Ao analisar essas categorias de AC, Wildson Santos (2007) enfatiza que do item a ao item e há referência ao conhecimento e ao desenvolvimento de habilidades em relação à atividade científica, enquanto de $f$ a $k$ temos referência a "conhecimentos, habilidades e valores relacionados à função social da atividade científica, incluindo categorias de natureza cultural, prática e democrática" (SANTOS, 2007, p. 478). Associamos o primeiro grupo de categorias com a visão I, e o segundo grupo com a visão II de Douglas Roberts (2007). A partir da identificação desses dois tipos distintos de abordagem da educação em ciências, Santos (2007) defende enfaticamente que esses dois grandes domínios não são antagônicos, mas complementares e imbricados.

Esses dois grandes domínios estão centrados no compreender o conteúdo científico e no compreender a função social da ciência. Apesar de serem enfatizados de formas diferentes pelos autores que discutem educação científica, eles estão inter-relacionados e imbricados. Pela natureza do conhecimento científico, não se pode pensar no ensino de seus conteúdos de forma neutra, sem que se contextualize o seu caráter social, nem há como discutir a função social do conhecimento científico sem uma compreensão do seu conteúdo (SANTOS, 2007, p. 478).

Entendemos que Santos (2007) advoga pela superação da suposta polarização entre visão I e visão II, como estamos defendendo. Em outras 
palavras, não existe tal polarização. Claramente não podemos abordar o conhecimento científico sem contextualizá-lo, assim como não há como abordar problemas sociais que envolvem ciência sem articular conhecimentos científicos (considerando que conhecimento científico é muito mais amplo do que apenas conceitos, modelos e teorias). De todo modo, o que parece irreconciliável na polarização apontada por Roberts (2007) são as matrizes curriculares, tributárias, por um lado, da própria organização da ciência e, por outro, de questões sociais que envolvam ciência, tecnologia e sociedade. Neste sentido, advogamos pela segunda matriz curricular.

Partindo da ideia de sentido fundamental da AC, como proposto por Norris e Phillips (2003), questionamos se o uso do termo "alfabetização" remete à ideia de ciência como uma linguagem. Este parece ser um campo não consensual, também. Ático Chassot (2003) defende a ideia de que a ciência pode ser entendida como linguagem. A este respeito afirma: "a ciência pode ser considerada como uma linguagem construída pelos homens e pelas mulheres para explicar nosso mundo natural" (CHASSOT, 2003, p. 91). Entendendo a ciência como linguagem que nos permite pensar sobre o mundo natural, Chassot (2003) aponta o seguinte:

A elaboração dessa explicação do mundo natural - diria que isso é
fazer ciência, como elaboração de um conjunto de conhecimentos
metodicamente adquirido - é descrever a natureza numa
linguagem dita científica. Propiciar o entendimento ou a leitura
dessa linguagem é fazer Alfabetização Científica (CHASSOT, 2003,
p.93).

Isabel Martins (2010), por sua vez, defende que os termos "Alfabetização" e "letramento", nas expressões "Alfabetização Científica" e "letramento científico", devem ser considerados como apropriações metafóricas de conceitos desenvolvidos no campo de estudo da linguagem e letramento. Martins entende que esta apropriação metafórica se sustenta em outra metáfora subjacente, a saber, a metáfora da "linguagem da ciência”. 
Compreender ciência como uma linguagem, isto é, em termos de suas dimensões discursivas (linguísticas, semióticas e sociais) reforça nosso questionamento de que a expressão Alfabetização Científica possa ser tomada em seu sentido literal. A base desse questionamento está no fato de que, como existem diferentes formas de conceituar o que é linguagem, existirão diferentes formas de definir a expressão "linguagem da ciência" e diferentes propostas de como e para que ensiná-la e aprendê-la (MARTINS, 2010, p. 367, grifos da autora).

Embora Martins também considere a relevância das discussões acerca do que se chama de "linguagem da ciência", a autora parece ser menos enfática do que Chassot no que se refere a considerar a ciência como linguagem, em especial por considerar a pluralidade de entendimentos sobre o que é linguagem. Por isso, prefere focar na ideia de metáforas.

Martins afirma que não é incomum que haja uma apropriação metafórica de conceitos entre diferentes domínios de conhecimento. Salienta que existem algumas apropriações problemáticas. Contudo, defende que “quando a apropriação se dá com base na utilização de um conceito como metáfora, asseguram-se condições para o desenvolvimento de um raciocínio produtivo por meio do qual é possível avaliar os limites de novos conhecimentos que se produzem" (MARTINS, 2010, p.366). A autora busca, então, o conceito bakitiniano de língua social como referência para compreender a chamada "linguagem da ciência". Esta referência permite, de acordo com a autora, "a possibilidade de considerar a ciência como linguagem, para além do reconhecimento superficial das especificidades do vocabulário ou dos termos técnicos que a caracterizam" (MARTINS, 2010, p. 367). Tornar-se proficiente nessa linguagem envolveria, então, "compreender as práticas sociais de produção e validação de conhecimentos" (idem, p.368). Essas considerações acerca da linguagem da ciência são fundamentais, de acordo com a autora, para desenvolver uma noção de AC.

A partir do entendimento de Soares (2003) de que a definição de letramento depende do contexto sócio-histórico-político, Martins (2010, p. 372) aponta a relevância de conhecermos a história dos livros didáticos e 
currículos, como consideração da dimensão histórica da AC. Igualmente importante para a autora é buscarmos a compreensão de "como se constroem as histórias dos meios de comunicação, das possibilidades de acesso e de difusão da informação científica, da caracterização do público entre especialistas e não especialistas, e da crescente legitimação de espaços de divulgação científica como espaços educativos" (MARTINS, 2010, p.372). A autora conclui, no entanto, que são poucos "os trabalhos que tratam dessas questões ou que fazem relações entre elas e a questão do letramento científico" (idem)

Entendemos que a educação científica é marcada por diversas tensões, isto é, para discutirmos fundamentos da educação científica, ou propostas de ensino mais pontualmente, é necessário que sejam consideradas uma série de variáveis, como os objetivos educacionais pretendidos, as condições concretas para o desenvolvimento de programas de ensino ou de atividades pontuais, a heterogeneidade das pessoas (Professores e Alunos) que potencialmente serão afetadas por eventuais propostas, etc. Em síntese, considerar essas e outras variáveis significa reconhecer minimamente a complexidade e as tensões que envolvem a educação científica. Assim, podemos afirmar que não podem existir formas pré-estabelecidas de ensinar ciências. Podemos afirmar, também, considerando essas tensões, que é impossível alcançarmos, ou mesmo almejarmos, consensos acerca do que é, ou deveria ser, a educação científica. Portanto, consideramos que a Alfabetização Científica, estando inserida nesta complexidade que envolve a própria área de educação científica, não deve se pretender consensual. Assim, o uso indiscriminado do termo AC apenas como um slogan pode ser nocivo a ponto de tornar-se um jargão sem significado algum. Por isso, acreditamos que o uso deste termo deve vir, sempre, acompanhado de uma visão educacional explícita e uma visão de ciência igualmente explícita. $\mathrm{O}$ sentido da AC não deve estar no termo em si, mas na maneira como o usamos em nossas pesquisas, currículos, ou em nosso discurso de maneira geral. 


\subsection{Convergindo para uma questão de pesquisa}

A partir da revisão da literatura em AC apresentada acima, notamos que há a expectativa de que o ensino de ciências possibilite a reflexão e a ação dos estudantes com relação ao mundo natural e social em que estão inseridos. Isto implica que o interesse que vem sendo demonstrado é o de uma formação geral de todos os estudantes e não uma formação técnica e propedêutica. Chamou-nos a atenção, ainda, a suposta polarização identificada em diversos trabalhos, bem representada pelas visões I e II propostas por Roberts (2007), entre perspectivas mais focadas nos aspectos internos do conhecimento científico e perspectivas que focam em questões sociais envolvendo a ciência. Entendemos que o mundo social deve ser a referência da educação em ciências, isto é, defendemos que o conhecimento científico deve ser um meio e não um fim em si mesmo.

Uma das conclusões a que podemos chegar a partir da revisão de parte da literatura sobre AC que apresentamos anteriormente é que esses debates estão inseridos em uma série de tensões que necessariamente se apresentam: tensões e disputas relacionadas aos objetivos educacionais atribuídos ao ensino de ciências; tensões que representam as condições concretas às quais estão submetidas as reflexões educacionais; tensões sobre metodologias (de pesquisa e de ensino), etc. Consideramos que essas tensões sempre estarão presentes na educação científica e, portanto, nas discussões sobre AC. São tensões que não são superáveis, mas que têm o potencial de promover o diálogo entre pesquisadores e educadores em ensino de ciências, condição indispensável à produção de conhecimento e à prática educacional.

Assim, reconhecer que o debate sobre AC está inserido em uma série de tensões intrínsecas à educação científica implica considerar que existe uma necessidade constante de diálogo e contextualização sobre esta temática. Defendemos que este constante diálogo deve se dar a partir de problemas e conflitos que estão relacionados, principalmente, aos desafios da formação de pessoas pertencentes ao seu tempo, que busquem a compreensão do mundo que as cercam, sobretudo para que possam 
participar de maneira crítica e democrática de decisões em que estão implicadas. Assim, uma das questões essenciais que deve perpassar os diálogos sobre a $\mathrm{AC}$, e que faz parte das tensões a que nos referimos, é a seguinte: Quais são os problemas emergentes do mundo hoje?

Entendemos que um dos problemas emergentes do mundo hoje está relacionado à comunicação entre as pessoas: como as pessoas acessam as informações sobre diversos acontecimentos do mundo? Mais precisamente, um dos problemas emergentes do mundo de hoje envolve as relações estabelecidas entre as pessoas e a mídia: quais narrativas sobre o mundo (político, cultural, social, científico, tecnológico, etc) as pessoas têm acesso? Como se relacionam com estas narrativas? São apenas passivas das narrativas contadas por grandes conglomerados de comunicação ou têm possibilidades de criar suas próprias narrativas através da mídia?

Em nossa revisão de trabalhos sobre AC encontramos indicações da relevância acerca da comunicação científica, em especial a importância atribuída à formação para uma leitura crítica de materiais presentes em meios de comunicação, como apontado no documento Twenty First Century Science (ROBERTS \& BYBEE, 2014, p. 547), por Millar e Osborne (1998), Martins (2010) entre outros.

Considerando ainda os problemas emergentes de hoje, podemos afirmar que vivemos o período das Fake News, que influencia as eleições das nações mais importantes - e perigosas - do mundo. A facilidade com que discursos de ódio têm penetrado nas sociedades faz com que "fantasmas" que pareciam superados retornassem. Exemplo disto são os nacionalismos que ganham cada vez mais força na Europa. Grandes grupos de interesse nunca se voltaram tanto ao controle da mídia, consequência direta da chamada "sociedade da informação" (ou desinformação!).

Se estas questões - por sua amplitude e complexidade - parecem distantes dos desafios enfrentados por educadores e educadoras em ciências, esta é somente uma falsa impressão. A mesma sociedade marcada pelas Fake News é a que acompanha movimentos de negação das ciências, como o 
movimento anti-vacina, os grupos terraplanistas e os que negam o aquecimento global. Se concepções ingênuas de ciências foram até o momento interpretadas como "epistemologias espontâneas" manifestadas por estudantes, agora fica claro que as mesmas são fruto de embates sociais.

Nosso atual mundo tecnológico tem como uma de suas características o dinamismo e rapidez na circulação de informações e de novos conhecimentos. As pessoas têm acesso quase irrestrito às notícias e comentários sobre os mais recentes avanços da ciência e da tecnologia, através dos mais variados meios de comunicação, tais como TV, rádio e internet. Assim, o ensino de ciências não pode se restringir a uma educação meramente formal, descolada da realidade concreta do mundo em que estão inseridos educadores e educandos. Neste sentido, entendemos ser papel da escola preparar os cidadãos e cidadãs para uma leitura crítica do mundo e, particularmente, uma leitura crítica da mídia sobre ciência. Esta é uma perspectiva que tem sido debatida na literatura sobre AC. De acordo com Ruth Jarman e Billy McClune (2007), "uma característica marcante da literatura em Alfabetização Científica é o intenso foco sobre a ciência na mídia, particularmente da ciência nos noticiários" (JARMAN \& McCLUNE, 2007, p. 5, tradução nossa). Os autores afirmam que para a vasta maioria dos adultos a mídia constitui a principal fonte de informações sobre a ciência e, significantemente, sobre os assuntos relacionados à ciência que têm impactos sobre a sociedade. Zimmerman e colaboradores (1999) defendem que "claramente a habilidade de ler e avaliar criticamente a mídia é uma importante habilidade para os cidadãos em uma democracia" (ZIMMERMAN et al., 1999, p.1). Jarman e McClune defendem, ainda, que as narrativas (stories) presentes nos jornais "podem ser cativantes, divertidas ou mesmo atraentes e podem despertar nosso interesse e imaginação, sendo especialista ou não no assunto" (JARMAN \& McCLUNE, 2007, p. 6). Como afirma Hodson (2018, p.31), os estudantes que são letrados em mídia são capazes de acessar, compreender, analisar, avaliar, comparar e contrastar a informação de uma variedade de fontes, além de utilizar essas informações criteriosamente e de forma adequada para sintetizar sua 
própria visão detalhada do tópico ou da questão sob consideração. Além disso, para o autor canadense, os alunos que passam por uma formação em mídia durante as aulas de ciência são capazes, entre outras coisas, de:

[...] verificar as intenções do escritor de determinar qualquer subtexto e significado implícito, detectar vieses e interesses escusos e distinguir entre, de um lado, informações boas e confiáveis e, de outro lado, aquelas pobres e não confiáveis. Eles estão alertas para o fato de que os especialistas dos meios de comunicação impressos, gráficos e falados usam vocabulários, gramáticas, sintaxes, metáforas e referencias particulares, com o objetivo de capturar a nossa atenção, acionar nossas emoções, persuadir-nos de um ponto de vista e, em certas ocasiões, ignorar por completo as nossas faculdades críticas. Eles entendem que o material sob análise pode ser tendencioso e pode usar uma variedade de técnicas jornalísticas, tais como linguagem emotiva, hipérbole e insinuações, fotos e imagens provocadoras e música de fundo emocionalmente manipuladora, para persuadir os leitores, telespectadores e ouvintes de um ponto de vista particular. Para que os estudantes desenvolvam estas capacidades, é preciso haver um programa sistemático de instrução, prática, apoio e crítica. (HODSON, 2018, p. 32)

Contudo, temos o desafio de desenvolver, no atual contexto educacional brasileiro, práticas coerentes com fundamentações teóricas como as apontadas por Hodson. Mariana Pezzo, em sua tese de doutorado (PEZZO, 2016), afirma que embora a escola e os diferentes integrantes da comunidade escolar estejam inseridos em relações cotidianas com a mídia e com tecnologias de informação e comunicação (TICs), ainda não há no Brasil, e em muitos outros países, "estratégias e políticas de abordagem da mídia e de suas tecnologias em suas interfaces com processos de ensinoaprendizagem e o ambiente escolar" (PEZZO, 2016, p. 19). Pezzo (2016) parte da convicção de que a abordagem das interfaces entre a produção midiática e o ensino de ciências é indispensável, especialmente para um ensino comprometido com a problematização das relações entre Ciência, Tecnologia e Sociedade (CTS). 
Os apelos em defesa de uma educação para/pela mídia estão atrelados, em geral, a anseios como a declarada intenção em trabalhar com os estudantes a partir de um ponto de vista de reflexão e ação sobre a sociedade da qual são integrantes. Existem algumas expressões associadas a um conjunto de preocupações, anseios, estudos e práticas relacionados à formação de pessoas para o uso e análise críticos dos meios de comunicação e das tecnologias de informação e comunicação, tais como os apontados por Pezzo (2016, p.23): "leitura crítica de mídia, mídia-educação, media literacy, educomunicação, dentre outras". O termo "educomunicação" tem sido amplamente usado no contexto brasileiro e da América Latina, especialmente através da influência de um dos fundadores deste movimento, o professor da Escola de Comunicação e Artes (ECA) da Universidade de São Paulo (USP), Ismar Soares.

A literatura que busca aproximações entre as áreas de comunicação e educação, que chamaremos de educação para as mídias, indica que um dos principais obstáculos desta área está relacionado à pouca atenção dada para a formação, inicial e continuada, de profissionais da educação (BÉVORT \& BELLONI, 2009). Há um déficit, particularmente, de formação para a mídia nas licenciaturas (PEZZO, 2016). Tendo estes apontamentos em vista, e considerando o contexto da $\mathrm{AC}$ que apresentamos, o objetivo geral desta tese será investigar as possibilidades e limitações da aproximação entre a educação científica e a educação para as mídias. De maneira mais específica, nossa pesquisa buscará investigar como Professores de Física em formação inicial avaliam e propõem a problematização da mídia na educação científica em disciplinas regulares de um curso de licenciatura em Física. Assim, as questões que guiarão nossa pesquisa podem ser colocadas da seguinte maneira:

Quais são as potencialidades e limitações do uso da mídia na formação inicial de Professores de Física, do ponto de vista da articulação entre conhecimentos sobre mídia, ciência e ensino? 
Como Professores em formação inicial de física avaliam e propõem a inserção da mídia na educação científica?

Quais características da mídia são evidenciadas por Professores em formação em busca de objetivos educacionais específicos?

Como os Professores em formação inicial avaliam a imagem da ciência veiculada pela mídia? Quais abordagens possíveis os Professores em formação inicial empreendem para problematizar tais visões?

Quais são as principais tensões que os licenciandos enfrentam ao buscar aproximações entre mídia e o ensino de Física?

O contexto desta pesquisa se deu no curso de Licenciatura em Física do Instituto Federal de São Paulo, campus São Paulo. Mais especificamente, investigamos a atuação de Professores de Física em formação inicial em duas disciplinas ministradas pelo proponente desta tese: uma delas intitulada "Introdução à Educação e Divulgação da Ciência" (nos referiremos a ela pela sigla EDC), oferecida regularmente para turmas de segundo semestre em Licenciatura em Física desta instituição; E a outra intitulada "Oficina de Projetos de Ensino 1" (nos referiremos a ela como PE1), oferecida a licenciandos do $5^{\circ}$ e $7^{\circ}$ semestres. Esta disciplina é atrelada ao estágio supervisionado obrigatório e foi estruturada a partir de projeto submetido pelo proponente desta tese e avaliado e aprovado pela coordenação do curso. A disciplina buscou a aproximação entre educação para as mídias e o ensino de ciências, tema desta tese.

Nos próximos capítulos delinearemos nossas concepções educacionais e nossa compreensão pela busca por aproximar perspectivas da educação para as mídias e o ensino de ciências. Vale ressaltar que esse entendimento é fruto de reflexão teórica, pautada na literatura, mas só se completa com a prática no curso de formação de Professores, refletindo com os licenciandos sobre a inserção e problematização da mídia em aulas de Física. Portanto, mesmo a parte de fundamentação teórica da tese pode ser entendida como sendo tributária da prática em sala de aula, assim como a prática em sala de 
aula foi influenciada pela reflexão teórica. A seguir fazemos uma breve apresentação dos capítulos desta tese.

No capítulo 2 abordaremos a epistemologia e pedagogia freireana, buscando convergências de sua teoria para questões sobre a mídia. Vale ressaltar que Paulo Freire não se debruçou sistematicamente sobre esta temática, isto é, não desenvolveu uma teoria sobre a mídia, ou sobre o papel da mídia na formação das pessoas. Contudo, alguns esforços já foram empreendidos em busca de aproximar a obra de Paulo Freire e as questões sobre mídia (MEDITSCH \& FARACO, 2003), além de o próprio Freire declarar que mesmo não tratando diretamente sobre as questões da mídia, as considera dentro do horizonte geral de sua teoria do conhecimento (FREIRE \& GUIMARÃES, 2011, p. 66). O capítulo 2 está dividido em duas seções. Em linhas gerais, na seção 2.1 apresentamos a epistemologia freireana, focando principalmente no conceito de diálogo como condição indispensável tanto para a construção quanto para a apreensão de conhecimento. Na seção 2.2 buscamos convergências do trabalho de Freire para questões relacionadas à mídia. Focamos, sobretudo, na não neutralidade da produção da mídia e nas relações entre a mídia e o exercício do poder.

No capítulo 3 apresentamos reflexões sobre a mídia. Este capítulo está dividido em quatro seções. Inicialmente, na seção 3.1, apresentamos reflexões sobre as possibilidades de usos da mídia como propaganda política e manipulação das pessoas. Esta seção está embasada exclusivamente no livro Mídia: Propaganda política e manipulação de Noam Chomsky (2013). A principal conclusão desta seção é que a abordagem empreendida por Chomsky se configura como uma postura militante diante da mídia que, embora seja fundamental, não é suficiente para os desafios da educação para as mídias. A seguir, na seção 3.2, apresentamos um problema emergente de nosso tempo: as "Fake News". Nesta seção buscamos problematizar a dicotomização entre "notícias falsas" e "notícias verdadeiras". A tese central desta seção é que este dualismo é insuficiente para lidar com os problemas das Fake News, particularmente considerando que as produções midiáticas 
não são neutras e envolvem uma série de interesses que devem ser levados em consideração. Uma das conclusões desta seção é que a prescrição de listas, propostas principalmente por grandes conglomerados de comunicação, com atitudes a serem tomadas para identificar e não propagar Fake News é insuficiente para uma atuação crítica e criativa dos cidadãos e cidadãs diante da mídia. Defendemos que iniciativas sistematizadas através da educação formal é a melhor forma de prepará-los para lidarem com tais questões. Assim, na seção seguinte (3.3), apresentamos algumas perspectivas associadas à chamada "Educação para as Mídias". Dentre as discussões desta seção, destacamos a convergência de diversos autores sobre a necessidade da inserção das discussões sobre a mídia na formação de Professores. Por fim, na seção 3.4 buscamos algumas convergências entre a educação para as mídias e o ensino de ciências. Destacamos os trabalhos de Mariana Pezzo $(2011$; 2016) e de Renata Ribeiro e Maria Regina Kawamura (2008).

No capítulo 4 apresentamos um estudo de caso, no qual analisamos três reportagens publicadas no ano de 1919 sobre os desdobramentos das expedições inglesas que observaram o eclipse solar total neste mesmo ano. A análise se deu buscando aproximar perspectivas da Educação para as Mídias e da História da Ciência. A análise apresentada neste capítulo fez parte de uma atividade desenvolvida com os licenciandos em física do IFSP. O objetivo da atividade foi buscar uma possibilidade de aula de Física que problematizasse materiais de mídia, ao mesmo tempo que problematizasse a própria ciência e as relações sociais que envolveram o episódio histórico selecionado. Em nossa análise buscamos salientar a propaganda empreendida pela mídia, principalmente pelo jornal inglês The Times, acerca da Teoria da Relatividade Geral e como isto impulsionou a imagem de Einstein ao mundo. Além disso, o episódio foi contextualizado a partir das hostilidades entre cientistas ingleses e alemães diante do período da primeira guerra mundial.

No capítulo 5 buscamos sintetizar as discussões dos capítulos precedentes, com a intenção de indicar alguns parâmetros para a 
aproximação entre a educação para as mídias e o ensino de ciências. A principal defesa é que essa aproximação deve buscar a problematização tanto da mídia, discutindo questões como a importância da confrontação entre diferentes materiais sobre um mesmo tema, as intencionalidades e a não neutralidade da mídia, etc., quanto questões relacionadas à ciência, tais como suas implicações sociais e tecnológicas e suas características epistemológicas. Por fim, defendemos que é indispensável, ao buscar aproximações entre perspectivas da educação para as mídias e o ensino de ciências na formação de professores, negociar as tensões geradas por essa aproximação nas práticas de ensino. Assim, essa aproximação deve considerar três eixos interdependentes: Mídia, Ciência e Ensino.

No capítulo 6 apresentamos o contexto no qual a pesquisa se desenvolveu, assim como a metodologia empreendida para analisar os materiais produzidos por Professores de Física em formação, que compõem o corpus desta tese. Este capítulo está dividido em três seções. A seção 6.1 contém o "Campo" da pesquisa: apresentamos em detalhes as disciplinas ministradas no curso de licenciatura do IFSP. Na seção 6.2 apresentamos o Corpus da pesquisa: atividades e gravações de seminários dos licenciandos. Na seção 6.3 apresentamos a metodologia da Análise Textual Discursiva, discutindo como foram empreendidos os processos de "unitarização", “categorização" e a “construção de metatextos” em nossa análise.

No capítulo 7 apresentamos a análise dos materiais desenvolvidos pelos licenciandos em física. A análise foi feita de maneira separada entre os materiais produzidos (corpus) em cada uma das disciplinas que compõem o campo de nossa pesquisa. A análise foi organizada com base nos três eixos propostos no capítulo 5: Mídia, Ciência e Ensino.

Por fim, fazemos algumas considerações finais, retomando a defesa da educação científica como um meio e não como fim em si mesma, isto é, a busca por uma educação científica que esteja relacionada a questões emergentes do mundo; A defesa de uma educação científica que problematize a mídia; Quais foram as principais tensões enfrentadas na 
proposição da aproximação entre educação para as mídias e ensino de ciências no contexto da formação inicial de professores de física; Quais foram as principais limitações das disciplinas ministradas e quais encaminhamentos possíveis para futuras intervenções na formação de professores, entre outras. 


\section{Capítulo 2}

\section{Epistemologia freireana e o sentido}

\section{da educação}

Paulo Freire foi um reconhecido educador e filósofo brasileiro, tendo se destacado por sua pedagogia/epistemologia libertadora. Entendemos que uma das premissas mais essenciais do pensamento de Freire seja a da educação como um ato político. Esta premissa implica que o educador deve ter claro a quem dirige sua prática. Isto é, o educador deve tomar uma posição com relação à realidade na qual ele e seus educandos estão submetidos. Freire esteve, certamente, ao lado dos oprimidos. Daí todo seu esforço intelectual e político em busca de uma educação libertadora.

Esta tese se insere nas discussões sobre a educação em ciências naturais, mais especificamente sobre o ensino da Física, que nunca foi objeto de trabalho de Paulo Freire. Contudo, não é novidade a apropriação não apenas da pedagogia freireana, mas de sua epistemologia no ensino de ciências. Pretendemos discutir alguns aspectos relacionados à construção da ciência, e como isto implica em seu ensino, a partir de um quadro epistemológico freireano. Além disso, cabe ressaltar que o objetivo principal desta tese é a problematização da mídia no ensino de ciências. Assim, buscaremos na obra de Paulo Freire, também, apontamentos sobre comunicação e sobre o papel da educação, e do Professor, frente às questões relacionadas a essa temática.

\subsection{Construção e apreensão de conhecimento: diálogo como motor de ambos os processos}

Algo a se destacar quando pensamos no ensino de ciências da natureza é a imagem criada acerca deste corpo de conhecimento. De fato, o conhecimento das ciências da natureza é bastante valorizado em nossa 
cultura, em especial por sua relação com o desenvolvimento tecnológico (embora não apenas por isso!). É notável, no entanto, o quanto este corpo de conhecimento é encarado de maneira mítica, como um conhecimento produzido por uma elite, por gênios e, portanto, pouco acessível às camadas mais populares da sociedade. Muitas pesquisas indicam que há, no imaginário popular, uma imagem de cientista como homem, branco, introspectivo, genial, etc. Este tipo de imagem que se tem a respeito do cientista pode ter um impacto negativo muito grande quando pensamos na identificação das pessoas com o conhecimento das ciências da natureza (GURGEL et.al, 2016). Este afastamento pode resultar em um elitismo cada vez maior com relação à construção e detenção do conhecimento científico, reforçando ainda mais eventuais discursos autoritários, que se utilizam da ciência em busca de poder.

Algo recorrente no ensino das ciências da natureza, particularmente no ensino da física, é um senso comum pedagógico explicitado, dentre outras coisas, por memorização de regras e fórmulas, além do uso de experimentos como verificação de teoria (DELIZOICOV, ANGOTI \& PERNAMBUCO, 2002, p.31). Ao passo que a Física seja trabalhada de maneira alheia à realidade dos alunos, alheia a seus interesses, suas curiosidades, suas questões existenciais, coloca-se em risco o valor deste conhecimento como uma forma sistematizada e crítica de leitura do mundo.

Consideramos que a Física é uma das formas que dispomos para compreendermos criticamente o mundo que nos cerca, de tal forma que esta compreensão de mundo expressa um esforço intelectual histórico, empreendido por muitos homens e mulheres, e que resultou em um corpo de conhecimento crítico e sistematizado, dinâmico, em permanente construção. Assim, consideramos essencial que o senso comum pedagógico apresentado acima seja superado por uma pedagogia que permita que os alunos possam tomar este conhecimento como forma de enriquecer sua leitura de mundo. Entendo que a pedagogia/epistemologia freireana possa ser tomada como referência em busca de um ensino de física mais humanizador, capaz de 
explorar as potencialidades do conhecimento científico em formar visões de mundo mais complexificadas e críticas.

A pedagogia freireana é baseada em uma concepção problematizadora da educação, preocupando-se fundamentalmente com a experiência do aluno. Esta pedagogia toma como ponto de partida os problemas e as necessidades dos próprios alunos. Com isto, concordamos com Delizoicov, Pernambuco e Angoti, quando dizem que "uma vez que o ponto de partida e de chegada é o mundo em que a vida se dá, o conhecimento científico aparece como uma das formas - nem a única nem a mais importante, mas indispensável na atualidade - de atuar e explicar criticamente" (DELIZOICOV et al, 2002, p.154).

O tipo de problematização destacado por Freire privilegia, sobretudo, a problematização da realidade social em busca de uma mudança de consciência política (DELIZOICOV et al, 2002, p. 170). A educação problematizadora contrapõe-se ao que Freire chamou de educação bancária, que é autoritária e dogmática, baseada em um senso comum pedagógico como o expressado anteriormente.

O diálogo é fundamental para a educação problematizadora. Para Freire, "não há que considerar perdido o tempo do diálogo que, problematizando, critica e, criticando, insere o homem em sua realidade como verdadeiro sujeito da transformação" (FREIRE, 2015, p.64). Como dissemos, é a problematização da realidade social que mais interessa na perspectiva freireana. Isto não significa, em hipótese alguma, que devemos nos restringir ao cotidiano dos alunos, aos problemas mais imediatos. Pelo contrário, "o que importa fundamentalmente à educação, contudo, como uma autêntica situação gnosiológica, é a problematização do mundo do trabalho, das obras, dos produtos, das ideias, das convicções, das aspirações, dos mitos, das artes, da ciência, enfim, o mundo da cultura e da história, que, resultando das relações homem-mundo, condiciona os próprios homens, seus criadores" (FREIRE, 2015, p. 112). 
Considerando o conhecimento científico como algo bem estruturado, como um conhecimento historicamente sistematizado, como podemos entender que seu ensino não possa prescindir do diálogo? O que se pretende com o diálogo em uma educação problematizadora? Para Freire, não se pretende com o diálogo que o educando reconstitua os passos dados no processo histórico de elaboração do saber científico e técnico. O que se pretende com o diálogo é "a problematização do próprio conhecimento em sua indiscutível reação com a realidade concreta na qual se gera e sobre a qual incide, para melhor compreende-la, explicá-la, transformá-la" (FREIRE, 2015, p.65).

Defender uma concepção de educação com base na problematização é acreditar tanto em uma educação para a liberdade, em que o educando possa ter uma relação ativa com o saber, que refletirá em sua prática diante do mundo, de maneira crítica, quanto considerar a própria característica da constituição do saber. Isto porque nenhum cientista construiu conhecimento sem que tenha sido problematizado, desafiado. Isto não implica que todo o homem e mulher que tenham sido desafiados tenham se tornado cientistas. Significa, sim, que o desafio é fundamental à constituição do saber (FREIRE, 2015, p.68). Assim, Freire defende o seguinte:

[...] se o conhecimento científico e a elaboração de um pensamento rigoroso não podem prescindir de sua matriz problematizadora, a apreensão deste conhecimento científico e do rigor deste pensamento filosófico não pode prescindir igualmente da problematização que deve ser feita em torno do próprio saber que o educando deve incorporar (FREIRE, 2015, p. 68-69).

Além de uma matriz problematizadora, devemos considerar que a produção do conhecimento científico surge através da interação entre sujeitos. Isto implica, de acordo com a concepção freireana, que não basta um sujeito cognoscente e um objeto cognoscível para a construção do conhecimento. Como a interação é fundamental, temos que considerar uma "tríade" sujeito-objeto-sujeito. Para Freire, "todo ato de pensar exige um sujeito que pensa, um objeto pensado, que mediatiza o primeiro sujeito do 
segundo, e a comunicação entre ambos, que se dá através de signos linguísticos" (FREIRE, 2015, p.84). Isto implica que o diálogo é uma relação epistemológica, uma vez que o objeto a ser conhecido vincula dois sujeitos cognitivos, levando-os a refletirem juntos sobre o objeto (FREIRE \& SHOR, 2011, p.170). Assim, tanto a problematização, quanto o diálogo, são centrais para compreendermos a concepção de construção e apreensão de conhecimento para Paulo Freire.

No ato de conhecimento não é possível negar a dimensão individual do sujeito que conhece. Mas acho que esta dimensão não basta para explicar o seu próprio ato de conhecer. $\mathrm{O}$ ato de conhecimento, no fundo, é social (...) a relação de conhecimento não termina no objeto, ou seja, a relação não é a do sujeito cognoscente com o objeto cognoscível. Esta relação se prolonga a outro sujeito, sendo, no fundo, uma relação sujeito-objeto-sujeito, e não sujeito-objeto (...) Eu me ponho diante do diálogo como quem, pensando em torno do pensar, percebe que o pensar não se dá na solidão do sujeito pensante, porque, inclusive, o pensar se faz na medida em que ele se faz comunicante. Por isso mesmo é que, então, o pensar não acaba no pensamento, mas se dá em torno de um objeto que mediatiza a extensão de um primeiro pensante a um segundo pensante (FREIRE \& GUIMARÃES, 1984, p.102; p.131-132).

Freire defende que o diálogo é fundamental para a construção do conhecimento. Esta visão epistemológica, de certo, tem implicações pedagógicas. Implica que o conhecimento do objeto a ser conhecido não pertence exclusivamente ao professor, uma vez que o objeto a ser conhecido medeia professor e aluno como sujeitos cognoscentes: "o objeto a ser conhecido é colocado na mesa entre os dois sujeitos do conhecimento. Eles se encontram em torno dele e através dele para fazer uma investigação conjunta" (FREIRE \& SHOR, 2011, p.169). Para Freire a construção conjunta de conhecimento, entre Professor e alunos, é o aspecto fundamental de uma educação libertadora. Apesar de diferentes, professores e alunos devem ser sujeitos cognitivos. O primeiro teste de uma educação libertadora, para Freire, é "que tanto os professores como os alunos sejam agentes críticos do ato de conhecer" (FREIRE \& SHOR, 2011, p.62). Freire destaca, 
no entanto, que o professor já teve certa experiência gnosiológica para escolher o objeto de estudo. Isto não significa, de acordo com autor, "que o professor tenha esgotado os esforços e todas as dimensões no conhecimento do objeto" (idem). Assim, como a educação para Freire é esta relação entre sujeitos cognoscentes, mediatizados pelo objeto cognoscível, em que o educador deve reconstruir, permanentemente, seu ato de conhecer, ela é, em consequência, um quefazer problematizador (FREIRE \& SHOR, 2011, p. 109).

Tendo em vista o papel do diálogo na problematização do conhecimento, pode-se afirmar que a linguagem está implicada no ato de conhecer. Como já salientamos, Freire considera que devemos partir das percepções dos alunos, de seus próprios níveis de compreensão da realidade. Isto significa que devemos partir da linguagem dos alunos, e não de nossa linguagem acadêmica e formal. Contudo, embora devamos valorizar a linguagem dos alunos, não podemos nos restringir a ela: “[...] partindo de sua linguagem [dos alunos], de seus níveis de percepção e conhecimento da realidade, procuramos, com eles, atingir um nível de compreensão e expressão da realidade muito mais rigoroso" (FREIRE \& SHOR, 2011, p.247). Então, embora devamos valorizar as experiências prévias dos alunos, suas histórias singulares, a cultura de seu meio imediato, devemos, por outro lado, buscar possibilidades para que os alunos se apropriem de conhecimentos sistematizados, como o conhecimento das ciências da natureza, de modo que possam transcender seu próprio meio ambiente.

"Se, de um lado, cometeria um grande erro, o educador progressista que, em nome do respeito à cultura, à identidade cultural dos educandos, reduzisse sua prática político-educativa a um basismo, sempre míope, a um focalismo, sempre alienante, não menos míope e alienante seria a prática educativa que, autoritária e arrogante menosprezasse, como coisa imprestável, o saber popular, a linguagem popular, os sonhos do povo. Não é possível superar a ingenuidade, o senso comum, sem assumi-los. Já disse uma vez e vale a pena repetir: ninguém chega lá partindo de lá, mas daqui” (FREIRE \& MACEDO, 1990, p.30). 
Ao discutir as diferenças entre a linguagem do povo e aquela linguagem tida como padrão, Freire destaca que o professor libertador deve demonstrar respeito à linguagem do povo, mostrar-lhes que essa linguagem é tão bela quanto a linguagem padrão, fazer com que o povo não sinta vergonha da própria linguagem e fazê-los perceber que sua linguagem também tem uma gramática, também tem regras, estrutura. Contudo, embora o professor tenha que destacar a beleza da linguagem do povo, deve considerar que há uma questão de poder no uso da linguagem. Assim, esse professor diria o seguinte a seu aluno: "Por causa do problema político do poder, você precisa aprender a se apropriar da linguagem dominante, para que você possa sobreviver na luta para mudar a sociedade" (FREIRE \& SHOR, 2011, p.124). Entendemos que o conhecimento da ciência está atrelado fortemente ao "problema político do poder". Igualmente, o uso e controle da mídia, como veremos na próxima seção, também está relacionada ao poder. Assim, tanto o conhecimento da ciência quanto a compreensão crítica da mídia são fundamentais na luta pela compreensão e transformação da sociedade.

Com isto, podemos notar que uma educação que se pretenda libertadora não pode ser alcançada apenas com o aprimoramento de metodologias e técnicas de ensino. Não se trata apenas de substituir metodologias ditas tradicionais por metodologias modernas como, por exemplo, trocar giz e lousa por apresentações em Power Point. A educação que se pretende libertadora deve buscar estabelecer uma relação diferente com o conhecimento e com a sociedade. No ensino de Física, especificamente, não é aceitável, em uma perspectiva problematizadora, que o foco esteja na memorização de fórmulas que só fazem sentido (se é que fazem!) dentro do contexto escolar, sem nenhuma relação com o mundo, com a realidade para além dos muros da escola. Isto não significa que o formalismo da Física, seus aspectos mais técnicos, sejam desprezíveis em uma educação libertadora. $\mathrm{O}$ que não é aceitável em uma concepção crítica de educação científica é que sejam depositados contendas técnicas, pois nesta concepção, "o proceder 
técnico se oferece como um problema ao qual ele deve responder" (FREIRE, 2015, p. 81).

A dicotomização entre leitura da palavra e leitura do mundo, apontada por Freire quando discute, principalmente, os problemas da alfabetização, afirmando que "ao ler as palavras, a escola se torna um lugar especial que nos ensina a ler apenas as palavras da escola, e não as palavras da realidade" também está presente no contexto do ensino da física. Ou seja, também é um problema do ensino da física a dicotomização entre contexto teórico e contexto concreto. Uma pedagogia assim dicotomizada diminui, de acordo com Freire, "o poder do estudo do intelectual de ajudar na transformação da realidade" (FREIRE \& SHOR, 2011, p.226).

Freire destaca dois momentos do que ele chama de "ciclos do conhecimento": um momento de produção e outro em que o conhecimento produzido é conhecido ou percebido. Ele aponta que geralmente tendemos a dicotomizar esses momentos, isolando um do outro. Como consequência, "reduzimos o ato de conhecer a uma mera transferência do conhecimento existente" (FREIRE \& SHOR, 2011, p.22). Isto implica, de acordo com Freire, na perda de qualidades necessárias e indispensáveis tanto para produzir conhecimento quanto para conhecer o conhecimento, como: "ação, a reflexão crítica, a curiosidade, o questionamento exigente, a inquietação, a incerteza" (FREIRE \& SHOR, 2011, p.23). Para Freire "todas essas virtudes são indispensáveis ao sujeito cognoscente" (idem).

Considerando os ciclos de conhecimento, podemos afirmar que é indispensável termos claro uma concepção de conhecimento. Ou seja, é essencial que tenhamos uma epistemologia que fundamente nossa prática pedagógica. Com relação às ciências da natureza, especialmente da física, consideramos que umas das discussões epistemológicas mais básicas está relacionada à rigidez lógica que muitas vezes se associa a este conhecimento, dando-lhe um valor de verdade inquestionável. Uma postura realista ingênua defende que a ciência descreve a realidade com o rigor do chamado método científico, que garantiria a segurança deste conhecimento. 
Esta é uma postura bastante criticada entre os filósofos da ciência, desde o século passado. Em geral, posturas que supervalorizam o papel da ciência, que defendem o chamado método científico como um método único de produção rigorosa de conhecimento, que veem a ciência como uma descrição fiel da realidade, são chamadas de posturas cientificistas. O cientificismo pode ser entendido como uma postura que supervaloriza a ciência por meio do autoritarismo. Ser cientificista não é o mesmo do que ser científico! O cientificismo tem certezas como base de seu autoritarismo. A ciência, por sua vez, tem a dúvida e o permanente questionamento como motor de sua eterna e dinâmica produção.

Freire defende que a escola não deveria, jamais, impor certezas absolutas aos alunos. Pelo contrário, a escola deveria "estimular a certeza de nunca estar certo o bastante, método essencial para a pedagogia crítica" (FREIRE \& MACEDO, 1990, p.39). Tendo em vista essa posição epistemológica e pedagógica, que é também uma posição política, os educadores "devem assumir uma posição científica que não seja cientificista, uma posição tecnológica, que não seja tecnicista" (idem). Isto é, os educadores jamais devem negar a importância da ciência e da tecnologia, mas não deveriam, igualmente, reduzir a aprendizagem a uma compreensão tecnológica do mundo, ou a uma compreensão cientificista que perpetue um autoritarismo em nome, supostamente, de uma certeza alcançada por meio do método científico.

Criticando a visão cientificista, o método científico, buscando posturas mais questionadoras do que aquelas que apostam em certezas da ciência, estaremos fadados a apreciarmos um conhecimento menos rigoroso? Para Freire a resposta é claramente não. Há, especialmente no cientificismo, um falso rigor, que só é alcançado mediante o autoritarismo. Ao falar do conhecimento rigoroso na perspectiva libertadora, Freire faz uma crítica à visão de rigor de alguns cientistas, especialmente quando esses defendem que nunca devemos tentar interpretar a realidade, mas descrevê-la com imparcialidade. Freire afirma que "para os tradicionais, os cientistas que se dizem rigorosos, mas negam a interpretação, o conceito de observação 
implica que o observador tenha que colocar um vidro diante de si, e colocar umas luvas nas mãos, para não tocar, não ter contato com a realidade, [...] para não contaminar a realidade e não ser contaminado por ela" (FREIRE \& SHOR, 2011, p.140). Para Freire não somos observadores passivos, uma vez que somos capazes de intervir no mundo: "Nós nos tornamos algo mais porque estamos aprendendo, estamos conhecendo, porque mais do que observar, estamos mudando. Para mim, esta é uma das conotações do rigor criativo na educação dialógica, uma das conotações mais importantes. Se você não muda, quando está conhecendo o objeto de estudo, você não está sendo rigoroso" (FREIRE \& SHOR, 2011, p.141).

Defender que a ciência não descreve imparcialmente a realidade não implica em dizer que a atividade científica é um construto meramente intelectualista, totalmente abstrato ou construída de maneira arbitrária. A ciência é a busca por uma leitura crítica do mundo, que tem o objetivo de superar uma visão mágica do mundo baseada no senso comum. Freire defende que o conhecimento crítico ou científico não surge por acaso, como se não precisasse se submeter ao teste da realidade (FREIRE \& SHOR, 2011, p. 180). Para ele o rigor da ciência "vem de um esforço para superar uma compreensão ingênua do mundo. A ciência sobrepõe o pensamento crítico àquilo que observamos na realidade, a partir do senso comum" (idem).

Assim, ser um educador libertador não significa defender que os alunos possam fazer o que quiserem. Ser libertador não pode se confundir com ser licencioso, libertinoso. O educador crítico tem papel fundamental na formação dos alunos, levando em conta que a educação tem um caráter diretivo. A este respeito, Freire afirma o seguinte: "Por um lado, não posso ser autoritário. Por outro lado, não posso cair no laissez-faire. Tenho que ser radicalmente democrático, responsável e diretivo. Não diretivo dos estudantes, mas diretivo do processo no qual os estudantes estão comigo" (FREIRE \& SHOR, 2011, p.83). Isto implica uma postura muito rigorosa com relação ao conhecimento, ao contrário do que o senso comum acerca da obra de Freire pode indicar. 


\begin{abstract}
"Quanto mais seriamente você está comprometido com a busca da transformação, mais rigoroso você deve ser, mais você tem que buscar o conhecimento, mais você tem que estimular os estudantes a se prepararem científica e tecnicamente para a sociedade real na qual eles ainda vivem" (FREIRE \& SHOR, 2011, p.119).
\end{abstract}

Preparar-se científica e tecnicamente extrapola o mero domínio dos conceitos das ciências ou de aplicações técnicas. Passa por problematizar esse conhecimento em uma realidade concreta. Passa por entender as condições de produção e articulação do conhecimento científico. Neste sentido, a literatura atual em ensino de ciências indica que devemos ensinar não apenas os conceitos científicos, mas também devemos discutir aspectos relacionados à dinâmica de construção da ciência, enfatizando aspectos históricos, políticos, econômicos, culturais, etc.

Continuando na literatura atual de ensino de ciências, uma expressão que tem tomado grande proporção na área, como enfatizamos na introdução desta tese, é a "Alfabetização Científica". No Brasil, esta tem sido uma área de produção de conhecimento do ensino de ciências que busca muitas referências, ou pelo menos inspirações, em Paulo Freire. Em particular, muitos autores brasileiros inspiram-se em sua concepção política de alfabetização, que entende que a alfabetização vai muito além do processo mecânico de aquisição técnica das habilidades de leitura e de escrita. Para Freire, a alfabetização deve ser um projeto que permita às pessoas participarem da compreensão e transformação da sua sociedade. Tomar essa concepção de alfabetização como uma proposta de "Alfabetização Científica" passa por buscar uma postura crítica com relação ao conhecimento científico.

Um dos aspectos importantes acerca do conhecimento científico, como já discutimos, é que ele não é uma mera descrição da realidade e não detém verdades absolutas. A ciência é uma construção humana, um conhecimento criticizado ao longo da história por meio de inúmeras contribuições de homens e mulheres. Assim, é fundamental, como apontou o pesquisador em ensino de ciências, Clive Sutton (1997), que seja dada ênfase ao caráter 
interpretativo da ciência em seu ensino, em detrimento da mera visão descritiva da ciência tão presente em sala de aula. Isto é, devemos valorizar a ciência dentro da escola como um conhecimento que possibilita uma leitura crítica do mundo. Não como um único meio de leitura do mundo, nem o preferencial, mas como fundamental para compreender e atuar em nossa realidade, tendo em vista, sempre, a transformação do nosso mundo em um mundo mais justo, capaz de respeitar os anseios e necessidades de todos os seres humanos.

É importante considerar que a escola não pode ser entendida como espaço único, ou privilegiado, de transformação do mundo. O ensino das ciências da natureza, muito menos, poderá ser considerado como o gatilho de uma grande revolução social. Contudo, há de se considerar que a escola, e o ensino de ciências consequentemente, devem estar comprometidos com a formação crítica dos estudantes, de modo que tenham possibilidades de atuação política consciente no mundo que os cercam. A escola deve combinar forças com outros meios de atuação política, como movimentos sociais e culturais, por exemplo, em busca de uma transformação mais radical. Ver a prática em sala de aula como o único local capaz de gerar transformações é ao mesmo tempo ingênuo e temeroso, uma vez que pode gerar grandes decepções em professores progressistas frente às limitações de suas práticas.

A atuação crítica no mundo passa, entre tantos outros aspectos, por compreender as mensagens que a mídia nos impõem como narrativas hegemônicas sobre a realidade a que estamos submetidos. Além da necessidade de um posicionamento crítico a essas produções, é necessário que nos percebamos, educadores e educandos, cidadãos e cidadãs, como tendo potencialidades criativas, propositivas. Isto é, a discussão sobre a mídia deve pautar-se na construção de visões críticas e criativas, através de uma relação dialética entre diálogo e conflito. Gadotti, no prefácio do livro de Paulo Freire "Educação e Mudança", chama atenção que o que dá força ao diálogo entre os oprimidos é a sua força de barganha frente ao opressor. Assim, é o desenvolvimento do conflito com o opressor que mantém coeso o oprimido com o oprimido: "O diálogo de que nos fala Paulo Freire não é o 
diálogo romântico entre oprimidos e opressores, mas o diálogo entre os oprimidos para a superação de sua condição de oprimidos. Esse diálogo supõe e se completa, ao mesmo tempo, na organização de classe, na luta comum contra o opressor, portanto, no conflito" (GADOTTI, 1979, p.2)

Na próxima seção passaremos, então, a focar a concepção de diálogo e comunicação na busca por aproximarmos a teoria do conhecimento de Paulo Freire com questões relacionadas à mídia.

\subsection{Comunicação e diálogo: olhando para a Mídia a partir de Paulo Freire}

Freire reforça a importância crucial da comunicação no processo educativo afirmando que "não há comunicação sem dialogicidade e a comunicação está no núcleo do fenômeno vital" (Freire apud Pinheiro, 2015, p. 25292). A apresentação do mundo como algo estático e que não pode ser mudado configura-se como uma educação antidialógica e que gera, como aponta Pinheiro (2015), o silenciamento dos sujeitos. Pinheiro (2015) defende que os meios de comunicação têm um papel fundamental na manutenção - ou mudança - desta dinâmica perversa de silenciamento. A autora destaca a crítica de Freire ao uso da mídia no sentido de difundir apenas a versão única e hegemônica dos fatos, "como se o depósito deste conteúdo alienante nelas [nas massas populares] fosse realmente comunicação" (Freire apud Pinheiro, 2015, p. 25293).

Em concordância com sua visão de alfabetização, Freire entendia que a mídia poderia assumir um papel importante a partir do momento em que os sujeitos fossem estimulados a superar a leitura ingênua de textos, sons e imagens e passassem a fazer uma leitura crítica dos meios de comunicação. Pinheiro (2015) afirma que Freire defendia que:

“[...] em relação à mídia, a Educação precisava se basear no estímulo ao pensar crítico e à curiosidade, oferecendo um espaço de formação crítica para possibilitar que os sujeitos deixassem de lado a compreensão ingênua das mensagens transmitidas pelos meios de comunicação e pudessem exercer, de maneira plena e consciente, sua cidadania" (Pinheiro, 2015, p. 25293) 
A leitura crítica da mídia passa por compreender os traços ideológicos que as compõem, compreender seu contexto de produção. Como já salientamos, não há produção neutra possível de acordo com Paulo Freire.

"Uma leitura de mundo crítica implica o exercício da curiosidade e o seu desafio para que se saiba defender das armadilhas, por exemplo, que the põem no caminho as ideologias. As ideologias veiculadas de forma sutil pelos instrumentos chamados de comunicação. Minha briga, por isso mesmo, é pelo aumento de criticidade com que nos podemos defender desta força alienante. Esta continua sendo uma tarefa fundamental de prática educativodemocrática" (Freire, 2014, p. 124).

A busca por aproximar a teoria de Freire às questões relacionadas à mídia e, em particular às questões educacionais envolvendo a mídia, não é novidade, embora não tenha sido amplamente explorada. Contudo, é importante salientar que o próprio Paulo Freire chama a atenção de que não é um especialista no tema "meios de comunicação", ou em mídia, de maneira geral. Ainda assim, o educador e filósofo brasileiro considera que questões envolvendo este tema são consideradas dentro do horizonte geral de sua teoria do conhecimento e em seus trabalhos sobre educação.

[...] mesmo quando não venho tratando desses chamados meios de comunicação em trabalhos meus anteriores, mesmo quando não falo diretamente sobre eles, eu os considero, por exemplo, dentro do horizonte geral da teoria do conhecimento que venho desenvolvendo nos meus trabalhos sobre educação. (FREIRE \& GUIMARÃES, 2011, p. 66-67)

Uma das obras de Freire que chamamos especial atenção com relação ao tema desta tese é o livro "Educar com a Mídia: novos diálogos sobre a educação", que consta de diálogos entre Paulo Freire e Sérgio Guimarães sobre educação e sobre meios de comunicação de massa, de maneira geral, e com foco, muitas vezes, na influência da televisão na visão de mundo das pessoas e nas possibilidades pedagógicas que novas tecnologias poderiam dispor à educação brasileira. Ressaltamos que em edições mais recentes, após a morte de Paulo Freire, Sérgio Guimarães incluiu, neste livro citado, 
diálogos com outras pessoas acerca da temática das mídias. Em particular, damos destaque ao diálogo com Mariana Faraco, que entrou em contato com Guimarães, e outras pessoas do convívio de Paulo Freire, como parte de sua pesquisa que buscava aplicar as ideias de Paulo Freire à prática jornalística. Retomaremos esse diálogo entre Guimarães e Faraco mais adiante. Antes disso, passemos a alguns pontos do diálogo entre Freire e Guimarães.

Logo no início de seu diálogo com Sérgio Guimarães, Paulo Freire afirma que uma das coisas mais lastimáveis para um ser humano é ele não pertencer ao seu tempo. Assim, Freire se afirma como um homem da televisão, do rádio. Um homem de seu tempo. Contudo, chama a atenção para seu "consumo crítico" da mídia: "sou um telespectador tão exigente de mim mesmo que me cansa assistir a programas de televisão, porque não me entrego docilmente" (FREIRE \& GUIMARÃES, 2011, p. 31).

Para Freire, é fundamental, para lidar com os meios de comunicação, pensar a questão do poder.
[...] os meios de comunicação não são bons nem ruins em si mesmos. Servindo-se de técnicas, eles são o resultado do avanço da tecnologia, são expressões da criatividade humana, da ciência desenvolvida pelo ser humano. O problema é perguntar a serviço "do quê" e a serviço "de quem" os meios de comunicação se acham. E essa é uma questão que tem a ver com o poder e é política, portanto. (FREIRE \& GUIMARÃES, 2011, p.32)

Entendendo que um dos problemas centrais envolvendo a mídia é a questão do poder, e o risco que a sociedade civil inteira corre de "ficar manipulada pelos interesses de quem detém o poder sobre esses meios de comunicação" (FREIRE \& GUIMARÃES, 2011, p.33), Freire defende que educadores e educadoras "não podem, de maneira nenhuma, no mundo de hoje, silenciar ou botar entre parêntese esse problema" (idem).

Como educadores, temos de saber o que fazer para minimizar esse poder exacerbado nas mãos de um grupo antipopular, para aumentar a capacidade crítica das grandes massas populares, sobre quem recai o peso dos comunicados. Na verdade, o que se 
está fazendo, em grande parte, com os meios de comunicação, é comunicado! Em lugar de haver comunicação real, o que está havendo é transferência de dados, que são ideológicos e que partem muito bem vestidos. (FREIRE \& GUIMARÃES, 2011, p.33)

Claramente não podemos descontextualizar a fala de Freire. Já se passaram mais de trinta anos desde o período em que ele e Guimarães, a partir de seus diálogos, propuseram essas reflexões. De lá para cá, tivemos o advento da internet, o surgimento de mídias sociais e mídias alternativas, que tendem a disputar as narrativas sobre os acontecimentos do mundo com os grandes conglomerados que exercem poder sobre e através da mídia. Contudo, especialmente quando tratamos da televisão e rádio, alvo principal das reflexões de Freire e Guimarães, e que são as mídias mais consumidas pelos brasileiros ainda hoje (SECOM, 2016), consideramos que as afirmações de Freire são atuais. Além disso, também julgamos atual a consideração de que os meios de comunicação priorizam a transferência de dados e que são, necessariamente, ideológicos.

Ao imaginar uma possível atividade em sala de aula, propondo que os alunos assistam a programas de televisão e que tragam suas impressões e críticas para a sala de aula, Paulo Freire defende um debate sem que o educador tenha o direito de manipular os jovens. Ao contrário, o Professor deve respeitar as posições que os jovens fossem declarar.

[...] [o professor] poderia pretender inocular nos jovens sua visão política. Ele tem, aliás, o direito de tê-la também e de lutar por ela. Pois vê bem: eu não digo que o educador vá esconder sua visão. De maneira nenhuma! Ele tem que ter a coragem de dizer aos meninos como é que ele pensa também, desde que respeite a diferença entre ele e os meninos. (FREIRE \& GUIMARÃES, 2011, p.38).

Diante da tolerância, e do respeito profundo aos posicionamentos dos estudantes, proposto por Freire, cabe nos perguntarmos: como podemos, diante dessa postura, criticizar as visões dos estudantes? Entendo que a resposta seja através do diálogo e, sobretudo, através de um diálogo que gere conflitos e que chame a atenção para a questão do poder. Sérgio Guimarães, 
neste ponto do diálogo com Freire sobre o respeito ao posicionamento dos estudantes, e sobre a impossibilidade de manipulação, defende que os Professores podem discutir com os alunos "a maneira como esse chamado meio de comunicação vem, em nome de uma neutralidade que inexiste, explicitando uma ideologia que é, exatamente, a dos grupos de poder" (FREIRE \& GUIMARÃES, 2011, p.38).

No diálogo entre Sérgio Guimarães e Mariana Faraco, à época estudante de jornalismo, incluído no livro "Educar com a Mídia" em edição publicada após a morte de Paulo Freire, Guimarães chama a atenção que a posição de Paulo Freire em relação à mídia era eminentemente política. Neste sentido afirma:

Ele [Freire] encarava a questão política primeiro, fazia uma análise ideológica, a quem serve tal meio, a quem interessa...Ele costumava criticar muitas vezes a utilização da mídia não como meio de comunicação, mas como meio em que se reduzia a transmissão de informações a "comunicados", de maneira unidirecional [...] Este tipo de crítica Paulo já fazia na época: as pessoas que manipulam esses meios estão mais preocupadas em "enfiar" na cabeça do povo determinadas informações. (FREIRE \& GUIMARÃES, 2011, p.146)

Ao ser questionado por Mariana Faraco se Paulo Freire teria um posicionamento crítico à grande imprensa e à prática jornalística, se tivesse se detido mais especificamente neste tema, assim como tinha com relação ao sistema de ensino tradicional, Guimarães defende que o importante é criticar "o ato do professor-escola/jornalista-órgão de comunicação, que reduz sua atividade a um mero transmitir de informações, sem estimular a criatividade do aluno/leitor para a recriação do conhecimento" (FREIRE \& GUIMARÃES, 2011, p.148).

Um dos pontos centrais da teoria de conhecimento de Paulo Freire é o entendimento de que na comunicação e na educação, assim como em qualquer atividade humana, é impossível ser neutro. Daí sua defesa de que educação é ato político. Tendo isto em vista, Faraco questiona Guimarães 
sobre como Paulo Freire viria a questão da neutralidade na prática jornalística considerando, segundo ela, que "o ideal do jornalismo, para nós que estudamos, é recontar a realidade da maneira mais fiel possível, o que não significaria necessariamente uma neutralidade.” (FREIRE \& GUIMARÃES, 2011, p.150). Ao reponde-la, Guimarães chama a atenção para a prática do jornalista como uma prática profissional, dando destaque ao texto de Freire "O compromisso do Profissional com a Sociedade":

O verdadeiro compromisso é a solidariedade, e não a solidariedade com os que negam o compromisso solidário, mas com aqueles que, na situação concreta, se encontram convertidos em "coisas". Para que você entenda o problema da neutralidade, você precisa fazer uma análise ideológica não só do discurso, mas também das ações de quem se diz neutro [...]. No fundo, a chamada neutralidade nada mais é do que a manifestação ideológica de um compromisso enrustido, ou seja: um órgão de comunicação que não quer manifestar claramente seu compromisso, que não quer reconhecer que tem um compromisso com determinado grupo ou com ele próprio, costuma sustentar a ideologia da neutralidade (FREIRE \& GUIMARÃES, 2011, p.152).

Julgamos que o entendimento de que não há possibilidade de produção neutra seja um ponto central das contribuições de Freire para a aproximação que buscamos entre educação (mais especificamente educação científica) e mídia. É preciso enfatizar que as narrativas sobre o mundo, e sobre a ciência em particular, estão impregnadas por diversas visões de mundo. Assim, o que deve haver de mais básico na aproximação da educação com a mídia, além de perceber seus traços ideológicos, é a busca por identificar diferentes visões, conflitantes ou não, sobre um mesmo fato.

Assim, tomando a teoria do conhecimento de Freire para inserir a problematização da mídia na educação, e particularmente na educação científica, é fundamental que se considere que os sujeitos estão implicados na construção e reconstrução das interpretações sobre o mundo, com o mundo. Considerar que "Comunicação [é] a co-participação dos Sujeitos no ato de pensar (...) [a comunicação] implica uma reciprocidade que não pode ser rompida (...) comunicação é diálogo na medida em que não é 
transferência de saber, mas um encontro de Sujeitos interlocutores que buscam a significação dos significados." (FREIRE, 1971 apud MEDITSCH \& FARACO, 2003, p. 3). Com isto, percebe-se a relação imbricada entre comunicação e diálogo. E o diálogo, como já apontamos anteriormente, tem papel de destaque na epistemologia freireana. Não há construção ou apreensão de conhecimento sem diálogo: "Somente o diálogo, que implica num pensar crítico, é capaz, também, de gerá-lo. Sem ele, não há comunicação e sem esta, não há verdadeira educação(...) A educação autêntica não se faz de $\mathrm{A}$ para $\mathrm{B}$ ou de $\mathrm{A}$ sobre $\mathrm{B}$, mas de $\mathrm{A}$ com $\mathrm{B}$, mediatizados pelo mundo" (FREIRE, 1970 apud MEDITSCH \& FARACO, 2003, p. 3).

O diálogo deve ser entendido em relação dialética com conflito, como apontado por Gadotti. Assim, para aproximarmos as questões sobre mídia, e particularmente a mídia sobre ciência, e a educação científica, é imprescindível que a educação para e pelas mídias seja desenvolvida a partir de uma visão problematizadora e não bancária, que busque analisar as diferentes abordagens dadas a um mesmo tema. Para isso, como defende Pinheiro (2015), é fundamental

"a leitura e a discussão de textos de revistas e jornais. Porém, o trabalho não deveria se iniciar com a exigência de que os educandos leiam todos os textos integralmente, mas com a leitura de trechos dessas publicações, trabalhados de forma intensa e fluente para que educandos e educadores tenham tempo para ler, analisar, compreender, criticar e, se possível, reescrever esses textos.

$[\ldots]$

Neste ponto, a leitura de textos sobre um mesmo assunto em veículos de comunicação diferentes seria fundamental para compreender as múltiplas possibilidades de visões dos fatos e proporcionar aos educandos a oportunidade de se questionarem os motivos de jornais diversos se manifestarem de forma diferente (ou, em alguns casos, exatamente igual) sobre um acontecimento." (Pinheiro, 2015, p.25294, negrito nosso) 
Portanto, é fundamental, senão básico, confrontar diversas visões de mundo que possivelmente circulam. A compreensão de que existem diversas possibilidades de abordar um mesmo tema é condição primordial para que possamos construir nossas próprias visões de mundo. Ana Maria Freire, companheira de Paulo Freire nas décadas de oitenta e noventa, diz em entrevista à Mariana Faraco (2003), que Freire comparava os telejornais entre si para ver o modo com as notícias eram tratadas:

"Nós assistíamos diariamente aos telejornais, poderia ser tanto o do Bóris Casoy como o Jornal Nacional. Esporadicamente, assistíamos aos dois e, às vezes, também ao jornal da Cultura, para que Paulo pudesse analisar e procurar mais fidelidade ao fato que estava sendo narrado, para ver as deformações pelos interesses ideológicos e políticos que as emissoras transmitem.(...) Muitas vezes, ele chegava até a se irritar pela forma às vezes superficial e omissa de [ o Jornal Nacional ] dizer de fato a coisa, manipulando trechos de entrevista que tínhamos visto em outra emissora, induzindo a opinião pública a perpetuar a sociedade vigente. Foi contra essa sociedade que Paulo esteve sempre contra, e por isso pagou com quase 16 anos de exílio.” (ANA MARIA ARAÚJO FREIRE, entrevista em 08/04/2002 apud MEDITSCHI \& FARACO, 2003).

A declaração de Ana Maria Freire mostra como o sentido da comunicação não se dá de forma unilateral. Isto é, a interação entre emissorreceptor deve ser considerada na comunicação social. Em paralelo à pedagogia freireana, podemos afirmar que o conhecimento, ou informação, não se dá de alguém que detém o conhecimento para àqueles que, equivocadamente, são considerados tabulas rasas. Ao contrário, essa relação gnosiológica se dá na interação entre as pessoas, mediadas pelo mundo. Neste sentido, Meditsch afirma:

A substituição da ideia de "massa" pela de "gente" concreta e capaz de fazer uso de discernimento também abre as portas para a aplicação da Filosofia de Educação de Freire aos processos cognitivos envolvidos na comunicação midiática, tanto no pólo da criação e produção das mensagens quanto da recepção que, tal qual 
o aprendizado em sala de aula, não é passiva e nem acrítica como os teóricos de uma "comunicação bancária" antes supunham. (MEDITSCH, 2017, p. 138).

Assim, é imprescindível que se considere a potencialidade das pessoas em desenvolver visões críticas acerca do mundo, e sobre as questões veiculadas na mídia de maneira específica. Mas, tão importante quanto o desenvolvimento da capacidade crítica, na concepção freireana, é o desenvolvimento da capacidade propositiva, criativa: "a denúncia de uma situação requer sempre o anúncio do que pode ou deve substituí-la: o primeiro passo para transformar o mundo é saber que ele pode ser transformado, e que é possível fazê-lo" (MEDITSCH, 2016, p. 142). O objetivo desta tese é aproximar a educação para as mídias e o ensino de ciências, de modo que tanto a ciência quanto a mídia sejam problematizadas em aulas de física. Esta problematização deve buscar o desenvolvimento de visões críticas acerca da ciência e das narrativas que circulam na mídia e a valorização da criatividade das pessoas implicadas nos processos educacionais.

No próximo capítulo abordaremos algumas ideias sobre mídia, discutindo o seu papel na visão de mundo das pessoas, abordando questões mais recentes sobre as chamadas "Fake News", e questões mais específicas que constam na literatura a respeito da "educação para as mídias". Buscaremos, no fim deste próximo capítulo, algumas convergências desta temática para a área de ensino de ciências. Na sequência, apresentaremos um panorama com alguns parâmetros que julgamos essenciais para a problematização da ciência na mídia, a partir da concepção freireana e dos debates que compõem a literatura da educação para as mídias. 


\title{
Capítulo 3
}

\section{Mídia e Educação: intersecções \\ desdobramentos para o ensino de ciências}

\begin{abstract}
Nas sociedades modernas, em que o acesso à informação virou business, mercadoria preciosa e moeda de troca do capitalismo, o conhecimento, por sua vez, tornou-se cada vez mais exíguo e, por isso mesmo, fonte permanente de poder. De que adianta, portanto, a leitura da palavra, se a leitura do mundo não está sendo feita para a necessária articulação entre fatos, contexto e visão prospectiva do mundo? (Graça Caldas, 2006)
\end{abstract}

Considerando os anseios atuais da educação em ciências, discutidos na introdução desta tese sob o olhar da Alfabetização Científica, e considerando ainda a pedagogia e epistemologia freireanas, podemos notar que os processos educacionais devem estar atrelados à permanente busca por uma formação de estudantes que considere suas capacidades críticas e criativas de lidar com o mundo do qual fazem parte como cidadãos. Não se trata de "formar cidadãos", mas de considerá-los e respeitá-los como tais e buscar, a partir da educação, possibilidades concretas para que estes cidadãos desenvolvam níveis de consciência cada vez maior acerca do mundo e assim, almejem mudanças radicais a partir de sua reflexão e prática.

A reflexão e ação crítica se fazem necessárias em várias esferas da sociedade. Nosso recorte são as mídias, pois nos parece latente o crescente papel que elas desempenham em nossa sociedade. Considerando que a mídia, de certa maneira, molda a visão de mundo das pessoas e, ao mesmo tempo, são utilizadas como meio de expressão e comunicação entre elas, muitos pesquisadores e educadores têm apontado para a necessidade cada vez mais urgente de uma "educação para a mídia". Os apelos em defesa de 
uma educação para a mídia estão atrelados, em geral, a anseios semelhantes aos apontados no parágrafo anterior, particularmente a declarada intenção em trabalhar com os estudantes a partir de um ponto de vista de reflexão e ação sobre a sociedade da qual integram. Existem algumas expressões associadas a um conjunto de preocupações, anseios, estudos e práticas relacionados à formação de pessoas para o uso e análise críticos dos meios de comunicação e das tecnologias de informação e comunicação, tais como os apontados por Pezzo (2016, p.23): "leitura crítica de mídia, mídia-educação, media literacy, educomunicação, dentre outras". Nos chama a atenção o uso do termo media literacy, em que literacy é tomado em sentido amplo, representando objetivos como a apreensão de uma linguagem para além de seus aspectos técnicos. Isto é, espera-se com este termo considerar que ser "alfabetizado" para a mídia vai além de uma habilidade técnica de decodificar as mensagens da mídia. Douglas Kellner e Jeff Share, importantes referências na área de educação e mídia e filiados aos estudos da teoria crítica, destacam a relevância da educação para a mídia afirmando o seguinte:

\begin{abstract}
Uma vez que os programas de televisão, os videogames, a música e mesmo os brinquedos se tornaram grandes transmissores da nossa cultura, os contadores e vendedores das histórias do nosso tempo, é agora, mais do que nunca, que as crianças precisam aprender a questionar criticamente as mensagens que as cercam e usar a grande variedade de ferramentas disponíveis para expressar suas idéias e exercer plena participação na sociedade. (KELLNER \& SHARE, 2008, p. 689)
\end{abstract}

A seguir apresentamos uma discussão que destaca o uso propagandístico da mídia, particularmente relacionada ao papel desempenhado pela mídia na disseminação de concepções políticas que buscam, sobretudo, formar a opinião pública acerca de temáticas controversas. Essa discussão é pautada particularmente na obra "Mídia: Propaganda Política e Manipulação", de Noam Chomsky. Na sequência, focaremos em uma discussão atual na sociedade em geral, as Fake News. Nossa intenção será a de problematizar esta discussão. Embora 
concordemos que notícias falsas têm estado presente nos debates e decisões em nossa sociedade, acreditamos ser uma redução dos problemas relacionados à mídia considerar, apenas, se uma notícia é falsa ou verdadeira. Como temos defendido até aqui, e como pretendemos aprofundar a partir da literatura em educação para as mídias, as produções midiáticas não são neutras, carregam sentidos negociados entre quem produz e quem apreende as informações. Portanto, existe uma complexidade muito maior nessas produções, que impede um categorização dicotômica.

\subsection{Propaganda política e manipulação: uma visão militante de Noam Chomsky}

Notamos, através de nossa experiência pessoal e da apropriação de conhecimentos presentes na literatura, que a mídia desempenha papel relevante na formação da opinião e na construção de visão de mundo das pessoas e isto tem implicações em diferentes áreas, inclusive na educação científica que é o interesse desta tese. Considerando o papel que a mídia ocupa na política, Noam Chomsky (2013) formula a seguinte questão: "em que tipo de sociedade queremos viver e, sobretudo, em que espécie de democracia estamos pensando quando desejamos que essa sociedade seja democrática?” (CHOMSKY, 2013, p. 9). O linguista e filósofo estadunidense inicia sua discussão contrapondo duas concepções de democracia. Uma dessas concepções, de acordo com o autor, "considera que uma sociedade democrática é aquela em que o povo dispõe de condições de participar de maneira significativa na condução de seus assuntos pessoais e na qual os canais de informação são acessíveis e livres" (idem). Em contraposição, a outra concepção de democracia, ainda de acordo com o autor, "é aquela que considera que o povo deve ser impedido de conduzir seus assuntos pessoais e os canais de informação devem ser estreita e rigidamente controlados" (CHOMSKY, 2013, p.10). Para nós esta segunda concepção, supostamente democrática, parece condizer com um sistema totalitário/autoritário. Chomsky afirma que embora essa segunda concepção de democracia possa parecer estranha, é importante entender que ela é predominante (idem). 
Chomsky (2013) destaca o papel histórico do uso da mídia com finalidades propagandistas, em especial como propaganda governamental. Afirma que a primeira operação de propaganda governamental nos EUA ocorreu no governo de Woodrow Wilson, no contexto em que estava em curso o que hoje denominamos de "Primeira Guerra Mundial". De acordo com o autor, inicialmente neste período "a população estava extremamente pacifista e não via motivo algum que justificasse o envolvimento numa guerra europeia" (CHOMSKY, 2013, p.11). Contudo, o governo estava comprometido com a guerra e tinha que fazer algo a respeito. Criou-se, então, uma comissão de propaganda governamental, chamada de "Comissão Creel". Segundo Chomsky, em seis meses essa comissão conseguiu "transformar uma população pacifista numa população histérica e belicosa que queria destruir tudo o que fosse alemão" (idem). Chomsky (2013, p.13) conclui que "a propaganda política patrocinada pelo Estado, quando apoiada pelas classes instruídas e quando não existe espaço para contestá-la, pode ter consequências importantes". Pezzo (2016) destaca o período pós-primeira guerra como um marco inicial da "educação para mídia", tendo essas primeiras abordagens, na década de 1930, forte influência da teoria crítica da sociedade desenvolvida pela Escola de Frankfurt (PEZZO, 2016, p.30-31).

Este tipo de condução/coerção de visão de mundo apontados por Chomsky tinha, de acordo com o autor, respaldo em visões ditas democráticas. Chomsky destaca o jornalista e teórico da democracia liberal, Walter Lippmann, como exemplo de um democrata que estava envolvido com essas comissões de propagandas e valorizava seus feitos. No entendimento de Lippmann, de acordo com Chomsky (2013), o objetivo, dito democrático, era "obter a concordância do povo a respeito de assuntos sobre os quais ele não estava de acordo por meio das novas técnicas de propaganda política”. Chomsky afirma que, para Lippmann, isto era necessário, uma vez que para o democrata liberal "os interesses comuns escapam completamente da opinião pública e só podem ser compreendidos e administrados por uma classe especializada de homens responsáveis que são suficientemente inteligentes para entender como as coisas funcionam" (CHOMSKY, 2013, 
p.15). O filósofo estadunidense também critica fortemente o leninismo, afirmando que a "teoria liberal democrática e o marxismo-leninismo estão muito próximos em seus pressupostos ideológicos" (idem). O autor faz essa afirmação com base na noção leninista, segundo ele, de que "uma vanguarda de intelectuais revolucionários conquista o poder do Estado usando as revoluções populares como a força que os conduz até ele e depois guia as massas ignorantes para um futuro que elas são estúpidas e incompetentes demais para vislumbrar sozinhas" (ibdem). Para Chomsky (2013, p.16), ambas as perspectivas resultam em relações autoritárias de poder. A diferença estaria, apenas, em determinar onde está este poder: no Estado, na concepção leninista, ou nos empresários, na concepção liberal.

A concepção de democracia liberal, tal como defendida por Lippmann, implica que existem classes de cidadãos. De acordo com o autor, Lippmann afirmava que, em primeiro lugar, existiam os cidadãos que têm que assumir um papel ativo na gestão dos assuntos de interesse público. O outro tipo de cidadão, a maioria da população, são o que Lippmann chamava de "rebanho desorientado" (CHOMSKY, 2013, p.16). A função do segundo tipo de cidadão, que representa a maioria da população, seria, então, a de meros "espectadores". Por se tratar de uma democracia a população deve, em alguma instância, ter papel nas decisões. Nesta lógica que vê a maioria da população como espectadores, isto ocorre oferecendo ao povo, de vez em quando, a possibilidade de transferir seu apoio a um ou outro membro da classe de especialistas (classe que está envolvida nas decisões sobre os rumos da sociedade): "a essa escolha se dá o nome de eleição" (CHOMSKY, 2013, p.17). Para Chomsky, a lógica por trás deste modelo é o princípio moral imperativo de que "a maioria da população é simplesmente estúpida demais para conseguir compreender as coisas. Se tentar participar na administração de seus próprios interesses, só vai causar transtorno” (idem).

Chomsky (2013, p.23) entende que para manter os cidadãos como espectadores é necessário que essas pessoas sejam mantidas atomizadas, segregadas e isoladas. Este é um dos motivos pelos quais, de acordo com autor, houve - e ainda parece haver - um ataque dos empresários aos 
sindicatos de trabalhadores. A tática usada pelos empresários, no entanto, tornou-se sutil: "nada de capangas contratados e violência contra os operários", em vez disso, os empresários usaram "recursos mais sutis e eficazes da propaganda" (CHOMSKY, 2013, p.24-25). O intuito dessas propagandas era moldar uma imagem de que os sindicalistas eram "grevistas malvados e desordeiros" (idem). A mensagem era a de que todos precisamos viver juntos e em harmonia. Assim, inculcavam a ideia de que "tanto o executivo da empresa como o faxineiro têm os mesmos interesses" (ibdem).

Chomsky (2013) traz reflexões sobre algumas práticas usadas para moldar a opinião da população em vista de um interesse político. Uma delas é usar certas representações como realidade. Chomsky usa como exemplo a representação moldada pelos assessores do Presidente Kennedy com relação à guerra no Vietnã. A representação era de que a atuação americana era uma defesa contra uma agressão interna, pelos próprios vietnamitas, portanto, ao Vietnã do Sul. Essa foi a versão que se tornou oficial. Para Chomsky, "quando se tem a mídia e o sistema educacional sob controle absoluto e a universidade assume uma postura conformista, é possível vender essa versão" (CHOMSKY, 2013, p.37).

Chomsky considera, no entanto, a relevância do que chamou de "cultura de dissidência". Apesar de todo esforço propagandístico empreendido em busca de interesses escusos, Chomsky realça o surgimento de importantes movimentos populares, como o movimento ambientalista, movimento feminista, movimento antinuclear, entre outros (CHOMSKY, 2013, p.39). O autor entende que "as pessoas estão adquirindo a capacidade e a disposição de refletir profundamente sobre as coisas" (CHOMSKY, 2013, p.41). Pondera, no entanto, que embora seja perceptível e importante, este é um processo lento.

Chomsky dá destaque ao que ele chamou de "percepção seletiva" comentando sobre o papel decisivo da mídia em "selecionar" o que será dado destaque e que, em consequência, moldará a percepção das pessoas. Usa o 
caso de Armando Valladares, prisioneiro cubano que denunciou supostas torturas sofridas sob o regime de Fidel Castro. De acordo com Chomsky, este caso virou uma sensação na mídia norte americana, que descrevia as declarações de Valladares como uma demonstração de como era tratada a oposição política por Castro e como o Estado Cubano era um dos mais genocidas do século. As "atrocidades" de Castro foram reveladas de maneira tão convincente que "somente o mais frívolo e insensível intelectual do Ocidente virá em defesa do tirano”, escreveu o The Washington Post (CHOMSKY, 2013, p.48). Chomsky dimensiona a repercussão do caso destacando que Valladares foi homenageado pelo Presidente do EUA, Ronald Reagan, em comemoração ao Dia dos Direitos Humanos, "pela coragem de suportar os horrores e o sadismo do sanguinário tirano cubano" e, ainda, foi indicado como representante dos EUA na comissão de Direitos Humanos das Nações Unidas (idem). Dentre as ações de Valladares nesta comissão, Chomsky destaca seus serviços em defesa dos governos de El Salvador e Guatemala, acusados de terem cometido "atrocidades em tal escala que fazem com que o que ele [Valladares] sofreu pareça quase nada" (ibdem). De acordo com Chomsky, foi preparado um relatório dentro de uma prisão em El Salvador, com testemunho de prisioneiros sob juramento, com relatos detalhadas de torturas, inclusive por parte de militares norte americanos. Este relatório, juntamente com um videoteipe que mostrava as pessoas na prisão testemunhando sobre as torturas, foram distribuídos pela "Força-Tarefa Interconfessional para as Américas da Comarca de Marin". Contudo, a imprensa norte americana "recusou-se a cobrir a matéria. As emissoras de televisão recusaram-se a reproduzir o teipe" (CHOMSKY, 2013, p.50). Sem a mesma repercussão, a percepção das pessoas a respeito deste segundo caso foi, como consequência, diferente do primeiro. Isto é, Chomsky quer destacar, a nosso ver, como a seleção e o tratamento de um determinado assunto pode moldar a visão de mundo das pessoas.

Esta obra de Chomsky não pode ser considerada, a nosso ver, um aprofundamento teórico sobre a mídia, mas uma "denúncia” do que ele considera, a partir de sua posição política, como sendo um uso político e 
propagandístico da mídia com intencionalidades de alienação das pessoas. Entendemos que esta obra é, sobretudo, uma atuação militante. Neste sentido, Evélyne Bévort e Maria Luiza Belloni (2009), por exemplo, defendem a tradição de uma mídia-educação como uma atividade militante, pautada no princípio de que "não pode haver cidadania sem apropriação crítica e criativa, por todos os cidadãos, das mídias que o progresso técnico coloca à disposição da sociedade” (BÉVORT \& BELLONI, 2009, p.1082). As autoras consideram, no entanto, que a mídia-educação não pode limitar-se à militância. Fazendo um balanço dos avanços da área, elas chegam à conclusão de que os caminhos percorridos não deixam satisfeitas as pessoas que investiram neste campo, particularmente pela ausência de "políticas públicas mais efetivas que viessem imprimir às ações de mídia-educação um caráter mais sistemático e oficial, de modo a integrá-la no cotidiano da escola, indo além das experiências isoladas e militantes" (BÉVORT \& BELLONI, 2009, p. 1089). Esta questão será aprofundada na seção 3.3. Além disso, consideramos que os objetivos desta tese estão relacionados à busca por sistematizações e compreensões sobre a problematização da mídia, o que não se restringe, a nosso ver, à militância.

\subsection{FAKE NEWS: um problema da sociedade contemporânea}

É comum encontrarmos associações entre mídia e democracia: "a livre troca de ideias, informações e símbolos que nutrem os cidadãos e reabastecem o sistema como um todo têm sido vistos há muito tempo como uma base central das sociedades democráticas" (FENTON \& FREEDMAN, 2018, p. 108). No Brasil, em particular, uma das características do período de regime militar (1964 - 1985), antidemocrático, foi o controle da mídia, através de um programa sistemático de censura. Um controle da livre expressão de coletivos e de indivíduos. A liberdade de expressão e uma imprensa livre foram, e continuam sendo, vistas como condição fundamental para o exercício democrático. Contudo, como nos chama a atenção Paulo 
Freire, a liberdade de imprensa não deve ser confundida com licenciosidade de imprensa.

"Liberdade de imprensa não é licenciosidade de imprensa. Só é livre a imprensa que não mente, que não retorce, que não calunia, que não se omite, que respeita o pensamento dos entrevistados, em lugar de dizer que eles disseram A tendo dito M. Acreditando realmente na liberdade de imprensa, o verdadeiro democrata sabe, pelo contrário, que faz parte da luta em favor da imprensa livre a briga jurídica de que resulta o aprendizado ético, sem o qual não há imprensa livre." (FREIRE, 1994 apud MEDITSCHI \& FARACO, 2003, p. 10)

Vemos, portanto, que Paulo Freire chama a atenção para o exercício ético da atividade jornalística. Em outras palavras, a liberdade de expressão e a imprensa livre devem estar associadas à responsabilidade de quem produz e faz circular as mensagens sobre o mundo. Somente com o uso consciente desta liberdade e do reconhecimento de que as produções midiáticas não são neutras, por parte não só de jornalistas, mas de todos os cidadãos e cidadãs, poderemos ter uma mídia em consonância com os valores democráticos. Natalie Fenton e Des Freedman, ambos Professores do Departamento de Mídia e Comunicação da Universidade de Londres, apontam que nas democracias liberais do ocidente, em vez de termos uma mídia associada à democracia, vemos exatamente o contrário, pois estamos, segundo eles, diante de um tipo de mídia que:

[...] com frequência depende dos vulneráveis e se curva aos poderosos; um tipo de mídia cuja nobre cruzada pela verdade e justiça foi substituída por um carnaval de fofocas e espetáculo; um tipo de mídia que demonstra um compromisso com o consumidor, em vez de com as pessoas e a soberania; um tipo de mídia que já não é externa à sociedade de classes, mas sim uma parte constitutiva dela; um tipo de mídia que adotou os mantras do livre mercado, em vez das práticas difíceis envolvidas em assegurar a liberdade de expressão, participação política e renovação democrática (FENTON \& FREEDMAN, 2018, p. 108) 
Além dos interesses e das influências externas que atravessam a produção da mídia, e que certamente compõem a sua dinâmica de funcionamento, é notável o destaque que tem sido dado aos impactos das chamadas "Fake News" em diversas democracias. Os debates sobre esta temática têm focado, sobretudo, em seus desdobramentos sobre a política. Em trabalho recente publicado na prestigiada revista Science, o cientista político David Lazer e outros quinze cientistas que assinam o artigo (LAZER et al, 2018), apontam uma pesquisa que indica que informações falsas no Twitter são tipicamente retuitadas por muito mais pessoas, e muito mais rápido, se comparada a informações verdadeiras, especialmente quando o tópico é política (LAZER et al, 2018, p. 1095). Os autores chamam a atenção de que embora as fake news ganhem destaque no contexto político, elas também têm sido documentadas em informações sobre tópicos como vacinação, nutrição, princípios de comportamento, entre outros.

Lazer e colaboradores (2018) definem fake news como sendo "informações fabricadas que imitam o conteúdo de mídia na forma, mas não no processo ou na intenção da organização”. Continuam, afirmando que os canais de fake news não têm as normas editoriais e os processos da mídia para garantir a precisão e a credibilidade das informações. Além disso, alertam que as fake news se "sobrepõem a outros distúrbios de informação, como más informações e desinformação” (LAZER et al, 2018, p. 1094).

Considerando o papel negativo desempenhado pelas Fake News sobre a visão de mundo das pessoas e, sobretudo, seus impactos sobre a ordem democrática, podemos levantar o seguinte questionamento: quais intervenções podem ser eficazes para conter o fluxo e a influência das fake news? No artigo referido da Science, os autores indicam duas categorias de intervenções: “(i) aquelas que visam capacitar indivíduos para avaliar as fake news que encontram, e (ii) mudanças estruturais destinadas a prevenir a exposição de indivíduos a fake news em primeira instância” (LAZER, 2018, p. 1095). Interpretamos essas duas possibilidades da seguinte maneira: por um lado, educar as pessoas para o consumo crítico das novas mídias, através 
da educação formal ou não formal, e, por outro lado, criar dispositivos legais de normatização da produção e circulação de conteúdos midiáticos.

Ao falar do emponderamento dos indivíduos frente às fake news, os autores sugerem que há diversas formas de checagem de fatos, "desde sites que avaliam reclamações factuais de reportagens, como PolitiFact e Snopes, até avaliações de notícias de mídia com credibilidade, como o Washington Post e o Wall Street Journal, até informações contextuais sobre conteúdo inseridos por intermediários, como os usados pelo Facebook' (LAZER, 2018, p. 1095). Ao acessarmos o site PolitiFact ${ }^{2}$, por exemplo, é possível notar um repositório de notícias classificadas com diversos selos, com as seguintes possibilidades:

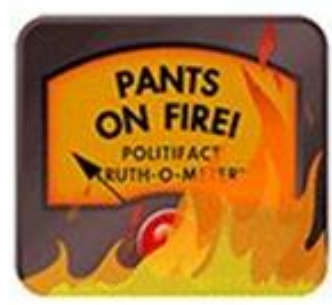

"Calças em Chamas"

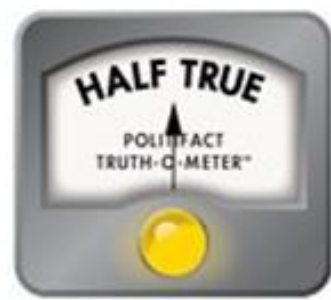

Meia Verdade

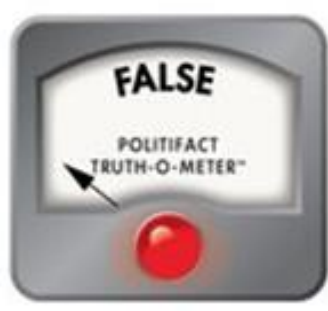

Falso

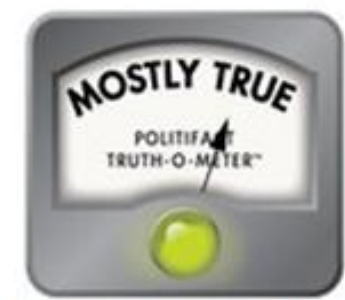

Na maior parte, Verdade

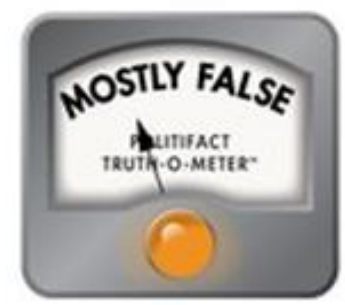

Na maior parte, Falso

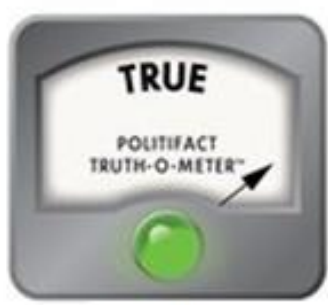

Verdade

É possível perceber, portanto, que há uma busca de enquadramento, em termos de verdade ou da falta dela, acerca das reportagens analisadas por esse site. Vale uma nota à categoria que traduzimos como "Calças em Chamas”. Interpretamos como uma categorização que busca não só mostrar que a notícia é falsa, mas, sobretudo, ridicularizá-la, uma vez que o termo

\footnotetext{
${ }^{2}$ Disponível em: https://www.politifact.com/. Último acesso no dia 31/05/2019 às 11h57
} 
"pants on fire" integra uma frase popular, normalmente associada a crianças, que diz: "Liar, liar, pants on fire”3.

Também é possível encontrarmos, no contexto brasileiro, iniciativas como as apontadas acima. Chamamos especial atenção à "Agência LUPA"4, que se diz a primeira agência de "fact-checking" do Brasil, fundada em $1^{\circ}$ de Novembro de 2015, e ao projeto "Fato ou Fake"5, lançado pelo portal de notícias do grupo Globo, G1, em 30 de julho de 2018.

A "LUPA" é uma agência de notícias especializada na técnica jornalística conhecida como "fact-checking", ou "checagem de fatos". De acordo com seus participantes, o objetivo da agência é produzir checagens em formato de texto, áudio e vídeo. Essas checagens são vendidas para os mais diversos meios de comunicação e, também, publicadas na própria página da agência, que atualmente está disponível no site da revista Piauí, e, por sua vez, no site da FOLHA e UOL. Embora esteja alojada neste site, a agência LUPA não tem, de acordo com seus organizadores, nenhum vínculo editorial com essas empresas. Os fatos checados pela agência LUPA estão, em geral, associados a afirmações feitas por personalidades de destaque nacional, a assuntos de interesse público e/ou que tenham ganhado destaque na imprensa ou na INTERNET em períodos recentes. Os organizadores da agência LUPA se dizem inspirados, principalmente, pelo International FactChecking Network ${ }^{6}$ (IFCN), rede internacional composta por plataformas de checagem que se reúnem em torno do Poynter Institute ${ }^{7}$ (EUA). A LUPA é um membro verificado da IFCN.

O projeto "Fato ou Fake", de acordo com o portal G1, tem como objetivo "alertar os brasileiros sobre conteúdos duvidosos disseminados na internet ou pelo celular, esclarecendo o que é notícia (fato) e o que é falso

\footnotetext{
${ }^{3}$ Em tradução livre: "Mentiroso, mentiroso, sua calça está pegando fogo!” ou, adaptando às influências culturais no Brasil: "Mentiroso, mentiroso, nariz de Pinóquio!".

${ }^{4}$ Disponível em: https://piaui.folha.uol.com.br/lupa/. Último acesso no dia 31/05/2019 às 13 h03.

${ }^{5}$ Disponível em: https://g1.globo.com/fato-ou-fake/. Último acesso no dia 31/05/2019 às $12 \mathrm{~h} 31$.

${ }^{6}$ Em tradução livre: Rede Internacional de Verificação de Fatos.

${ }^{7}$ Detalhes em: https://www.poynter.org/
} 
(fake) 8" (G1, 2018, grifos nossos). A ideia do projeto é que Jornalistas façam um monitoramento diário acerca de mensagens suspeitas muito compartilhadas nas redes sociais e por aplicativos como o WhatsApp. Além do G1, também integram o projeto: O Globo, Extra, Valor, CBN, GloboNews e TV Globo. Dentre outras iniciativas, o projeto disponibiliza um "bot" (robô) no Facebook e Twiter que responde a usuários destas plataformas midiáticas o que é falso ou verdadeiro, caso o assunto já tenha sido checado pelos jornalistas da Globo. E, ainda, cidadãs e cidadãos podem cadastrar seus números de WhatsApp para verificarem os links de reportagens checadas pelo projeto "Fato ou Fake".

Além dessas iniciativas mais sistematizadas, temos outras pontuais como a do site R7, da rede Record. Neste portal é possível encontrar, por exemplo, um "guia de como verificar se uma notícia é falsa antes de mandar no grupo da família"9. Este guia, publicado no portal R7, é uma reprodução de texto produzido pela BBC Brasilio. Neste guia, os leitores encontram algumas indicações de como proceder diante de produções midiáticas que tiverem contato, através de mídias convencionais e, principalmente, através das mídias sociais. Reproduzimos abaixo os cinco pontos de precauções indicados no guia:

1) Pare e pense. Não acredite na notícia ou compartilhe o texto de imediato.

2) Ela lhe causou uma reação emocional muito grande? Desconfie. Notícias inventadas são feitas para causar, em alguns casos, grande surpresa ou repulsa.

3) A notícia simplesmente confirma alguma conviç̧ão sua? Também é uma técnica da notícia inventada. Não quer dizer que seja verdadeira. Desenvolva o hábito de desconfiar e pesquisar.

\footnotetext{
${ }^{8}$ Disponível em: https://g1.globo.com/fato-ou-fake/noticia/2018/07/30/g1-lanca-fato-ou-fake-novoservico-de-checagem-de-conteudos-suspeitos.ghtml

${ }_{9}^{9}$ Disponível em: https://noticias.r7.com/tecnologia-e-ciencia/um-guia-de-como-verificar-se-umanoticia-e-falsa-antes-de-mandar-no-grupo-da-familia-14092018. Último acesso em 31/05/2019 às 17 h06.

${ }^{10}$ Disponível em: https://www.bbc.com/portuguese/brasil-45043716. Último acesso em 31/05/2019 às $17 \mathrm{~h} 10$.
} 
4) A notícia está pedindo para você acreditar nela ou, por outro lado, ela está mostrando por que acreditar? Quando a notícia é verdadeira, é mais provável que ela cite fontes ou dê links ou cite documentos oficiais e seja transparente quanto a seu processo de apuração.

5) Produzir uma reportagem assim que eventos acontecem toma tempo e exige profissionais qualificados. Desconfie de notícias bombásticas no calor do momento. (POTAL R7, 2018).

A continuidade do guia visa desenvolver prescrições de como as pessoas devem proceder na prática, para que as precauções indicadas sejam consideradas e, por fim, não se deixem enganar pelas famigeradas fake news.

1) Leia a notícia inteira, não apenas o título;

2) Averigue a fonte:

a. É uma corrente de WhatsApp ou de outra rede sem autoria alguma ou link para um site? Desconfie e, de preferência, não compartilhe;

b. Tem autoria? É uma fonte legítima, na qual você já confiou no passado? Se não, talvez seja melhor não confiar. Pesquise o nome do veículo, autor ou da autora no Google e veja o que mais essa pessoa está produzindo e para qual veículo de imprensa. Além disso, preste atenção para averiguar se o site que reproduz a notícia está publicando só notícias de um lado político, por exemplo, mostrando que talvez haja algum viés ideológico;

c. Há no texto referência a um veículo de imprensa, como se fosse o autor da notícia? Entre no site original do veículo de imprensa para verificar se a notícia está lá de fato;

3) Digite o título da notícia recebida no Google. Se for verdadeira, é provável que outros veículos de imprensa confiáveis estejam reproduzindo a mesma notícia; se for falsa, pode ser que veículos de checagem já tenham averiguado o boato. Pesquise nos resultados da busca; 
4) Pesquise, também, os fatos citados dentro da notícia. Ela se apoia em acontecimentos verificáveis? Por exemplo, se ela afirma que alguma autoridade disse algo, há outros veículos de imprensa reproduzindo o que essa autoridade falou? Tente procurar isso na internet;

5) Verifique o contexto, como a data de publicação. Tirar a notícia verdadeira de contexto, divulgando-a em uma data diferente, por exemplo, é um tipo de desinformação;

6) Pergunte para a pessoa que encaminhou a notícia para você de quem ela recebeu, se confia na pessoa e se conseguiu checar alguma informação;

7) Recebeu uma imagem que conta uma história? É possível fazer uma busca "reversa", por meio da imagem, e não por texto, e verificar em que outros sites ela foi reproduzida, o que pode dar pistas de sua veracidade. Salve a foto no seu computador e suba ela no seu mecanismo de busca ou cole o url dela nesse navegador:

\section{https://images.google.com/}

Se estiver no celular, tente neste site independente do Google: https://reverse.photos/

8) Recebeu um áudio ou um vídeo com informações? Tente resumir essas informações e procurá-las no Google. Exemplo: você recebe um áudio dizendo que no dia seguinte haverá greve de ônibus. Procure no Google: "greve de ônibus" junto com a data. Outra opção é buscar no Google: "áudio greve de ônibus WhatsApp", por exemplo. Essa busca pode resultar em um desmentido de uma agência de checagens de notícia, se ela não for verdadeira, ou em uma notícia real de algum órgão de imprensa, se for verdadeira;

9) Números: a notícia cita números de pesquisas ou de outros dados? Tente procurá-los isoladamente para checar se fazem sentido;

Fontes: NewsLitTip, CNJ (Conselho Nacional de Justiça), BBC, Factcheck.org (PORTAL R7, 2018). 
Chama-nos atenção a tentativa de estabelecer uma lista prescritiva de procedimentos a serem, passo a passo, seguidos pelos consumidores de mídia. Mesmo compreendendo a importância de tais pontos para a atuação crítica das cidadãs e cidadãos diante dos conteúdos produzidos pela mídia, não acreditamos que tais prescrições sejam o melhor encaminhamento para lidar com a mídia, sobretudo por buscar uma inoculação das pessoas, como se fossem vítimas passivas. Esta busca por inoculação, mesmo que bem intencionada, é igualmente perseguida, na nossa leitura, pelos projetos referidos anteriormente, como LUPA e "Fato ou Fake". A busca por inocular os indivíduos é uma perspectiva identificada na literatura de educação para as mídias como "medo da mídia", como teremos oportunidade de apresentar na próxima seção.

Chama-nos atenção, também, analisando tanto as iniciativas internacionais quanto nacionais, que o advento da INTERNET e das mídias sociais, embora permitam uma maior participação das pessoas no consumo e na produção de materiais da mídia, geram grandes desafios com relação à credibilidade do que tem sido consumido e produzido. Neste sentido, os autores do artigo da Science, já citado anteriormente (LAZER et al, 2018), propõem o seguinte questionamento: como a INTERNET e as plataformas de mídia social podem ajudar a reduzir a disseminação e o impacto das fake news? Esta é uma questão importante, sobretudo considerando que o "Google, Facebook e o Twitter muitas vezes são mediadores não apenas do nosso relacionamento com a mídia, mas também de nossos amigos e parentes" (LAZER et al, 2018, p. 1096). Algo que chama a atenção no funcionamento dessas plataformas de mídia social é que geralmente seus modelos de negócios dependem da monetização da atenção de seus usuários por meio da publicidade. Assim, essas plataformas "usam modelos estatísticos complexos para prever e maximizar o envolvimento com determinados conteúdos" (idem). Tendo isto em vista, os autores (ibdem) sugerem que seja possível ajustar esses modelos estatísticos para aumentar a ênfase na informação de qualidade. Contudo, os autores não entram em questões, que julgamos controversas e essenciais, tais como: o que significa 
informação de qualidade? quem deve normatizar esses modelos das mídias sociais? com quais parâmetros? em nome de quais interesses? Essas e outras questões devem ser problematizadas para que possamos pensar na possibilidade de mudanças desses modelos das mídias sociais, caso contrário, corre-se o risco de, simplesmente, censurarmos produções marginais, que não estejam dentro de perspectivas hegemônicas sobre os fatos. Isto é, corre-se o risco de empreendermos uma normatização que reforce a hegemonia dos meios de comunicação considerados "mainstream", em detrimento de mídias alternativas e, particularmente, em detrimento das possibilidades criativas das quais cidadãs e cidadãos dispõem em sua relação com a mídia.

Entendemos que as fakes news têm se configurado como um problema da sociedade contemporânea, haja visto seu papel decisivo no debate político, como mencionamos anteriormente. Contudo, é importante problematizarmos esse fenômeno. Em particular, é fundamental superarmos esse pretenso dualismo entre falso e verdadeiro, que tem sido pautado, sobretudo, pelos próprios canais de comunicação tradicionais, como o grupo Globo através do projeto "Fake ou Fato" e outros como mencionamos nos parágrafos anteriores, envolvendo grandes grupos de comunicação. Embora possam ser encaradas como iniciativas com preocupações reais acerca de um problema de nosso tempo, acredito que tais abordagens são reducionistas. A prática midiática envolve uma série de impositivos, de visões de mundo. Suas mensagens são recebidas por grupos diversos, que imprimem diferentes interpretações aos textos, imagens, sons, etc. Então, não deve se tratar, apenas, de etiquetar as produções midiáticas como verdadeiras ou falsas.

Para Fenton e Freedman (2018, p.110) a questão principal não deve ser a de estarmos cercados por Fake News, mas a de que temos vivido em "democracias fakes", nas quais enfrentamos contradições como a “coexistência da representação e participação política com um sistema econômico que não admite tais direitos, procedimentos ou reivindicações" (WILLIAMS apud FENTON \& FREEDMAN, 2018, p.110). Para os autores, 
a mídia é parcialmente culpada por essa democracia fake, pois "sua associação com o poder e sua utilização de sensacionalismo e frases de efeito degradam a qualidade do debate político e reduzem a competência dos cidadãos" (idem). Para os autores, os cidadãos foram transformados em consumidores e decisões coletivas transformadas em questões de necessidade e escolha individual, o que daria a ilusão de comunicação democrática. Para eles, este é um tipo de mídia "marcada pelo comércio, cumplicidade e cautela, em vez de pensamento crítico, criatividade e jornalismo consciente" (ibdem). Os autores também chamam atenção para a atuação, enviesada segundo eles, dos grandes grupos de comunicação frente aos problemas das fake news.

A grande mídia tem há muito tempo desempenhado seu papel essencial retratando debates e identificando controvérsias, mas sempre buscando "limitar o espectro estritamente à opinião aceitável" quando se trata de questões relativas à economia, imigração, ou intervenção estrangeira. Estamos agora perante uma nova fraude democrática em que instituições de mídia de elite - da BBC e New York Times ao Google e Facebook - estão usando a crise provocada pelo crescimento de políticas anti-hegemônicas para afirmar que somente eles são capazes de sustentar uma ecologia de informação que seja consensual, credível e racional que pode expor "fake news" e proteger "verdades estabelecidas" (FENTON \& FREEDMAN, 2018, p. 111).

Os autores chamam a atenção, ainda, que o poder de mercado alcançado por empresas como Google e Facebook não se deu em detrimento da influência dos grandes canais de comunicação já consagrados. Pelo contrário: "Google, Facebook e Twitter estão, se nada mais, reforçando o poder de definição de agendas dos principais nomes da imprensa mainstream por estarem facilitando o aumento de sua circulação" (FENTON \& FREEDMAN, 2018, p.113). Com isto, de acordo com os autores, o poder de filtragem de conteúdos a ser disseminado (conhecido como gatekeeping) do Google e Facebook funciona em conjunto com o de provedores de notícias mainstream (pe: Globo, Record, UOL, FOLHA, Estadão, etc.), "reforçando־se mutuamente em torno daquelas que consideram ser as notícias reais, 
legítimas e confiáveis" (idem). Consideramos, contudo, que a discussão deve estar além do dualismo entre falso e verdadeiro. Sobretudo, consideramos acrítica a posição de deixar nas mãos dos grandes meios de comunicação a tarefa de selecionar e pautar os fatos, assim como a tarefa de chancelar as versões dos fatos, com poder de decisão sobre o que é verdade ou não.

Por fim, como tentativa de exemplificar parte da complexidade que envolve a produção midiática, e problematizar o dualismo entre falso e verdadeiro, faremos uma breve análise de reportagens sobre o investimento público em educação no Brasil, em relação ao investimento feito em outros países. Particularmente, selecionaremos materiais que circulam na mídia que correlacionam o investimento em educação ao PIB (Produto Interno Bruto) do Brasil e de outros países.

Comecemos pela mensagem do Presidente do Brasil, Jair Bolsonaro, publicada em sua conta no Twiter, em 4 de março de 2019.

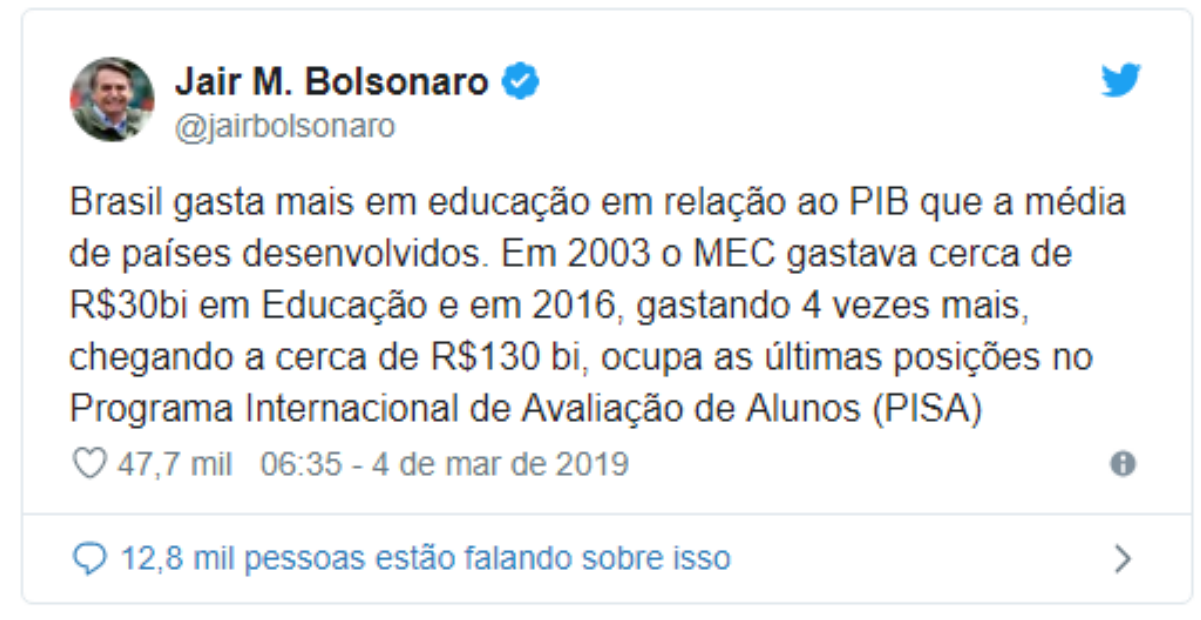

Vale destacar que a mensagem, no momento em que foi capturada a imagem acima, contava com aproximadamente cinquenta mil curtidas, além de quase treze mil pessoas falando sobre ela em suas redes sociais. Isto é, a repercussão foi grande. Esta afirmação, de que o Brasil investe mais em educação em relação ao PIB do que a média de países desenvolvidos é recorrente na mídia. 
Em fevereiro de 2019, o jornal online "Gazeta do Povo", publicou uma reportagem intitulada "Peru e Chile gastam menos em educação do que Brasil. E eles alcançam as melhores notas" ${ }^{11}$, assinada pela jornalista Eleni Kronka. Logo na introdução, a jornalista afirma o seguinte:

\footnotetext{
"O Brasil é um dos países que mais investe em Educação. Segundo o relatório Aspectos Fiscais da Educação no Brasil, divulgado pela Secretaria do Tesouro Nacional, ligada ao Ministério da Fazenda, o país investe em educação pública cerca de $6 \%$ do Produto Interno Bruto (PIB), valor tido como superior à média de 5,5\% destinada à área por parte de países integrantes da Organização para a Cooperação e Desenvolvimento Econômico (OCDE). (KRONKA, 2019, grifos nossos)
}

A jornalista entrevistou o economista Renan Pieri. Damos destaque à primeira pergunta feita: "Por que os resultados do Brasil na área de Educação ficam tão abaixo dos padrões internacionais, mesmo o país fazendo alto investimento, até mesmo acima da média mundial?" (KRONKA, 2019, grifos nossos). Pieri começa sua resposta com um conceito recorrente entre os economistas: "A questão pode se resumir em uma palavra: eficiência". Na sequência de sua resposta, vai um pouco além do jargão da "eficiência" e indica questões relacionadas a escolas em tempo integral, formação de Professores, e, por fim, o baixo investimento em formação infantil em relação ao investimento em ensino superior no Brasil. A jornalista continua a entrevista com uma variação da primeira pergunta:

O Brasil gasta em Educação muito mais do que outros países na relação com o PIB. Mesmo assim, amarga resultados pífios (estamos entre os últimos no Pisa). A isso soma-se o fato de o investimento feito em Educação não se refletir no desenvolvimento do País, no PIB. Por que isso acontece? (KRONKA, 2019, grifos nossos)

\footnotetext{
${ }^{11}$ Disponivel em: https://www.gazetadopovo.com.br/educacao/peru-e-chile-gastam-menos-emeducacao-do-que-o-brasil-e-eles-alcancam-as-melhores-notas-5mo5nrw7yq9poa113h8ioj4ro/. Último acesso em 03/06/2019 às $16 \mathrm{~h} 19$.
} 
Existe, claramente, o entendimento, por parte da jornalista, que o Brasil investe bastante em educação quando comparamos o percentual do PIB empreendido pelo país neste quesito, em relação a outros países, incluídos os integrantes da OCDE.

O JCNET ("Jornal da Cidade", versão online), jornal online da região de Bauru, no estado de SP, publicou no dia 03 de junho de 2019 um texto de opinião, intitulado: "Educação e seus recursos mal distribuídos"12, assinado por Dirceu Cardoso Gonçalves, tenente da Polícia Militar de São Paulo e dirigente da Aspomil (Associação de Assistência Social dos Policiais Militares de São Paulo). Neste texto, Gonçalves afirma o seguinte:

O problema não está na falta de recursos, mas na sua má distribuição. O Brasil investe na Educação 6\% do PIB (Produto Interno Bruto), percentual superior ao recomendado pela OCDE (Organização para Cooperação e Desenvolvimento Econômico), que é de 5,5\%, e acima de nações como Estados Unidos (5,4\%), México e Argentina (5,3\%), Chile (4,8\%) e Colômbia (4,7\%).

É o terceiro maior percentual mundial do PIB destinado ao setor, superado apenas por Nova Zelândia e Jamaica. (GONÇALVES, 2019).

Nossa intenção com esta rápida análise não é ser exaustivo, pois certamente existem mais exemplos de materiais que circulam na mídia afirmando que os investimentos em educação no Brasil são comparáveis, ou mesmo superiores, a países desenvolvidos, que estão muito acima do nosso país em desempenho escolar, se tomamos o PISA como referência, por exemplo. Tendo as afirmações que destacamos acima, a do Presidente Jair Bolsonaro, da Jornalista Eleni Kronka e a do Tenente Dirceu Gonçalves, podemos dizer que se tratam de fake news? Em que sentido poderíamos afirmar que sim ou que não? Basta dizer que sim ou que não?

Acreditamos que não basta afirmar que são fake news ou não. $O$ cerne da questão é identificar os interesses e as visões de mundo que sustentam as

\footnotetext{
${ }^{12}$ Disponível em: https://www.jcnet.com.br/editorias noticias.php?codigo=255942. Último acesso em 03/06/2019 às $18 \mathrm{~h} 28$.
} 
afirmações sobre o investimento em educação no Brasil. Contudo, antes das interpretações, vamos a alguns dados que podemos checar. Em primeiro lugar, segue gráfico com informações sobre o investimento em educação com relação ao PIB de alguns países, retirado de relatório da OCDE.

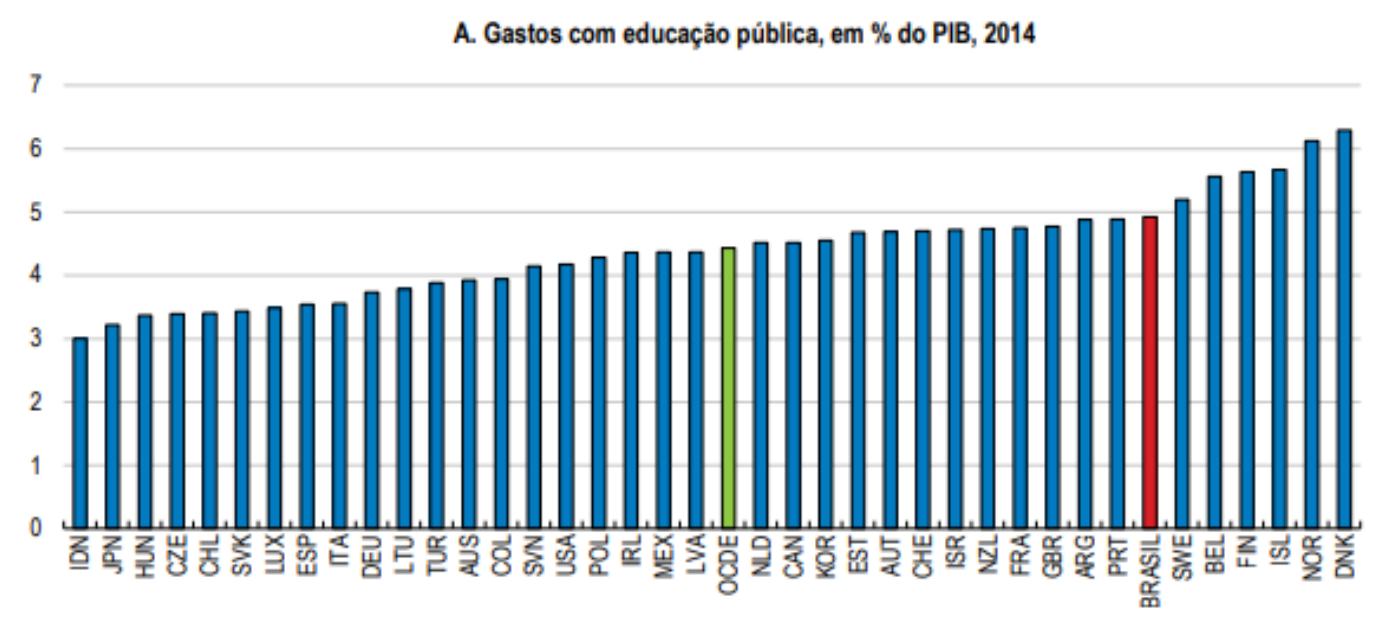

Fonte: Relatórios Econômicos OCDE (Brasil, 2018, p.31)

Em destaque em verde temos a média dos investimentos em educação em relação ao PIB de países da OCDE e em vermelho a porcentagem brasileira. Assim, de acordo com este gráfico disponível em relatório da OCDE ${ }^{13}$, podemos notar que o investimento do Brasil em educação, em relação ao seu PIB, é superior, em porcentagem relativa ao PIB, ao investimento de vários países tidos como desenvolvidos e que figuram em posições superiores a do Brasil em exames internacionais, como o PISA. Então, de acordo com os gráficos, não há incorreções aparentes nas afirmações de Bolsonaro, Kronka e Gonçalves, exceto a deste último, quando afirma que o investimento brasileiro, em relação ao percentual do PIB, é o terceiro maior do mundo. Podemos notar que pelo menos seis países, dos destacados no gráfico, investem um percentual maior de seu PIB em educação, em relação ao investido pelo Brasil. Contudo, não necessariamente se trata de um erro, ou um dado falso. Os dados utilizados por Golçalves podem ter se referido a períodos diferentes, ou a outras fontes.

\footnotetext{
${ }^{13}$ Disponível em: https://www.oecd.org/eco/surveys/Brazil-2018-OECD-economic-survey-overviewPortuguese.pdf. Último acesso em 03/06/2019 às $22 \mathrm{h08.}$
} 
Analisemos, abaixo, o gráfico com desempenho de vários países no PISA, referente ao ano de 2015.

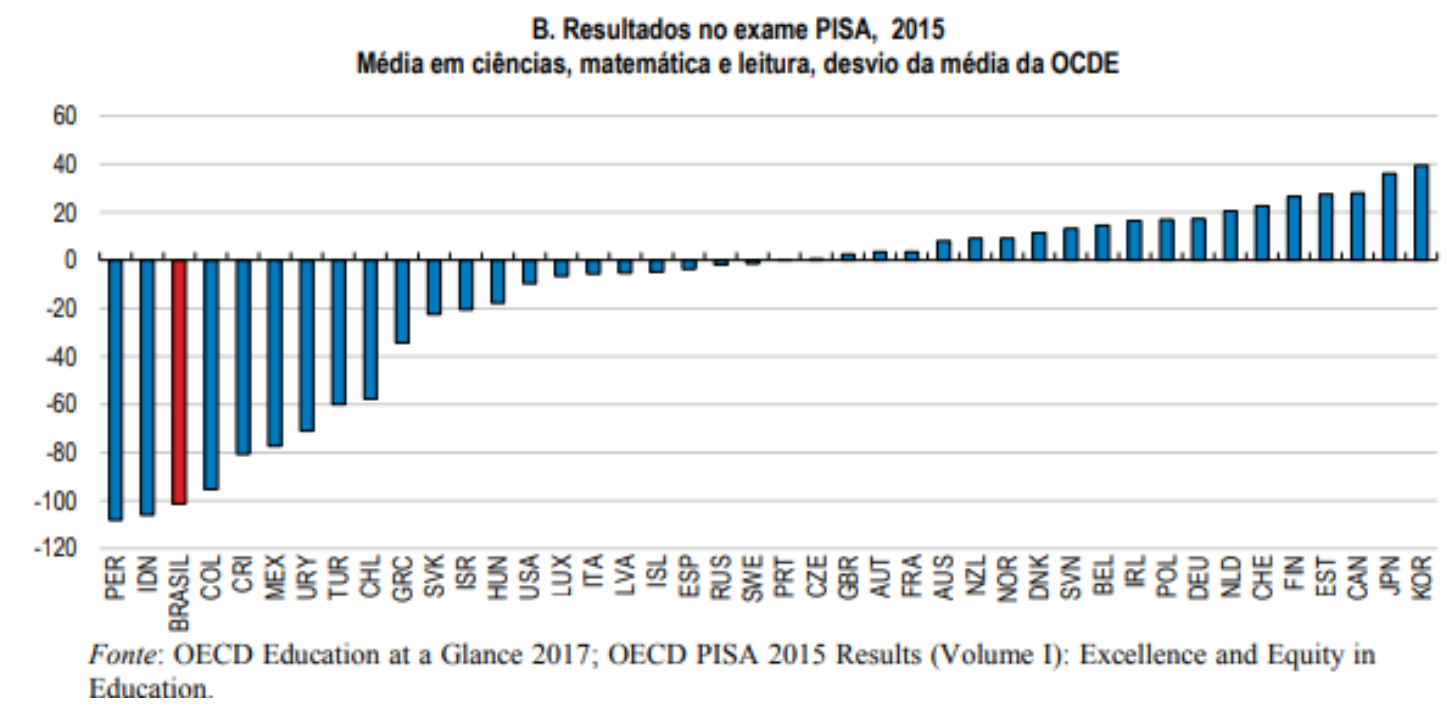

Fonte: Relatórios Econômicos OCDE (Brasil, 2018, p.31)

Neste gráfico, o ponto "zero" no eixo das ordenadas é a média dos países da OCDE em Ciências, Matemática e leitura. O Brasil, em vermelho, está aproximadamente 100 pontos abaixo da média, investindo quase $6 \%$ de seu PIB em educação. Tomemos como parâmetro o Japão: este país investe pouco mais de $3 \%$ de seu PIB, contudo, tem desempenho 40 pontos superior à média dos países da OCDE, e 140 pontos superior ao desempenho brasileiro. Consideremos, por um instante, como verdadeira a afirmação de que o desempenho no PISA implique, diretamente, qualidade educacional (o que, certamente, é discutível). De acordo com os dados acima, podemos descartar a necessidade de mais investimento financeiro na educação brasileira, já que o Brasil investe mais do que o Japão e tem qualidade educacional inferior? Será mesmo uma questão de "gestão"? de "eficiência"?

Aqui entra um ponto central do nosso exemplo: a seleção dos dados serve aos propósitos que se quer defender. Isto porque os dados não falam por si, nem em educação, nem em economia e nem na Física: por exemplo, com um mesmo conjunto de dados, Tycho Brahe "observava-interpretava" nosso sistema planetário como a Terra estando imóvel e no centro, sistema geocêntrico, enquanto Joanes Kepler “observava-interpretava” o Sol como o 
centro desse sistema. Além disso, o primeiro defendia que as órbitas eram circulares, enquanto o segundo defendia que as órbitas eram elípticas.

Para compreendermos minimamente a questão do investimento em educação, é fundamental que percebamos que é possível olhar de maneira diferente para os dados sobre tais investimentos. Além disso, é preciso compreender que podemos fazer a seleção de outros dados. Por exemplo, em vez de usar os dados de investimento em relação ao PIB, selecionemos o PIB per capita. Isto por uma razão muito óbvia: existe uma variação do número de pessoas em cada país. Além disso, existem variações de pessoas em idade escolar. E, ainda mais, existem históricos de déficits educacionais próprios de cada país como, por exemplo, a necessidade de formação básica de pessoas em idades consideradas como não ideais para essa etapa de formação. Por fim, podemos comparar o investimento médio por aluno matriculado.

Tomando a comparação que fizemos, entre Japão e Brasil, temos uma diferença de quase quatro vezes entre o PIB per capita desses países. De acordo com dados do Banco Mundial ${ }^{14}$ o PIB per capita brasileiro foi de $\$$ 9.812,30 em 2017, enquanto o do Japão foi de $\$ 38.430,30$ neste mesmo ano.

Além disso, considerando os dados publicados no estudo "Education at a Glance 2018 OECD Indicators"15, podemos notar que o Japão investe, em média, $\$ 12.120,00$ por aluno ao ano, considerando os investimentos feitos desde o ensino primário ao terciário. No Brasil, o montante é de $\$ 4.451,00$. A média dos países da OCDE é \$10.520,00. Isto é, quando olhamos para esses dados, verificamos que o investimento no Brasil é menos da metade da média de Países da OCDE e quase um terço se comparado ao Japão. Outros dados podem ser verificados na tabela abaixo.

\footnotetext{
${ }^{14}$ Disponível em: https://data.worldbank.org/indicator/NY.GDP.PCAP.CD?year high desc=true. Último acesso em 04/06/2019 às $10 \mathrm{~h} 57$.

${ }^{15}$ Disponível em:

http://download.inep.gov.br/acoes internacionais/eag/documentos/2018/EAG Relatorio_na integra.p df. Último acesso em 04/06/2019 às $13 \mathrm{~h} 39$.
} 
Table C1.1. Total expenditure on educational institutions per full-time equivalent student (2015) In equivalent USD converted using PPPs for GDP, direct expenditure within educational institutions, by level of education, based on full-time equivalents

\begin{tabular}{|c|c|c|c|c|c|c|c|c|c|c|c|c|c|c|}
\hline & \multirow[b]{3}{*}{ 戛 } & \multicolumn{5}{|c|}{ Secondary } & \multirow{3}{*}{ 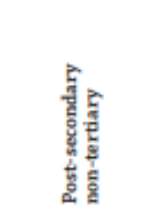 } & \multirow{3}{*}{ 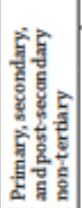 } & \multicolumn{3}{|c|}{ Tertiary } & \multirow{3}{*}{ 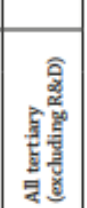 } & \multirow[b]{3}{*}{ 悬 } & \multirow{3}{*}{ 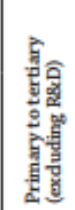 } \\
\hline & & \multirow{2}{*}{$\begin{array}{l}\text { है } \\
\text { है } \\
8 \\
\text { s. } \\
\text { है }\end{array}$} & \multicolumn{3}{|c|}{ Upper secondary } & \multirow[b]{2}{*}{ 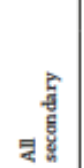 } & & & \multirow{2}{*}{ 兘 } & \multirow[b]{2}{*}{ 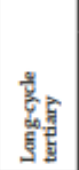 } & \multirow[b]{2}{*}{ घ } & & & \\
\hline & & & 焉 & 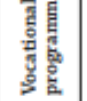 & 焉 & & & & & & & & & \\
\hline & (1) & (2) & (3) & (4) & (5) & (6) & (7) & (8) & (9) & (10) & (11) & (12) & (13) & (14) \\
\hline Australia & 9546 & 12466 & 12826 & 9328 & 12028 & 12303 & 9343 & 10766 & 21290 & 20122 & 20344 & 14159 & 12829 & 11497 \\
\hline Austria & 11689 & 15514 & 13514 & 16696 & 15432 & 15477 & 4876 & 13931 & 16700 & 17718 & 17555 & 13138 & 15043 & 13688 \\
\hline Belgium & 10211 & 12538 & 13138 & $13497 d$ & $13352^{d}$ & $13070^{4}$ & $\mathbf{x}(3,4,5,6)$ & 11856 & 11577 & 17538 & 17320 & 11627 & 12900 & 11812 \\
\hline Canada $^{1}$ & $9249^{4}$ & $\mathbf{x}(1)$ & $x(5)$ & $x(5)$ & 12900 & 12900 & $x(8)$ & $10468^{d}$ & $\mathrm{~m}$ & $\mathrm{~m}$ & $\mathrm{~m}$ & $\mathrm{~m}$ & $\mathrm{~m}$ & $\mathrm{~m}$ \\
\hline Chile $^{2}$ & 5064 & 4974 & 4852 & 5054 & 4909 & 4930 & a & 4996 & 4103 & 10164 & 8406 & 8067 & 5986 & 5888 \\
\hline Czech Republic & 5207 & 8714 & 7368 & 8566 & 8251 & 8476 & 2399 & 7075 & 18635 & 10870 & 10891 & 6365 & 7919 & 6918 \\
\hline Denmark & m & $\mathrm{m}$ & $\mathrm{m}$ & m & m & $\mathrm{m}$ & m & m & m & m & m & $\mathrm{m}$ & $\mathrm{m}$ & $\mathrm{m}$ \\
\hline Estonia & 6327 & 6614 & 6514 & 8048 & 7090 & 6861 & 7929 & 6663 & a & 12867 & 12867 & 8404 & 8133 & 7076 \\
\hline Finland & 9305 & 14682 & 8425 & $8587^{d}$ & $8543^{4}$ & $10482^{d}$ & $x(4,5,6)$ & 10025 & a & 17591 & 17591 & 10391 & 11518 & 10098 \\
\hline France & 7395 & 10268 & 13131 & 14963 & 13799 & 11747 & 9286 & 9897 & 14093 & 16805 & 16145 & 10638 & 11106 & 10040 \\
\hline Germany & 8619 & 10680 & 11423 & 15943 & 13652 & 11791 & 10736 & 10863 & 10149 & 17036 & 17036 & 10018 & 12139 & 10689 \\
\hline Greece & 5810 & 7099 & 5678 & 8513 & 6490 & 6786 & m & 6191 & a & 4095 & 4095 & 2601 & 5470 & 4957 \\
\hline Hungary & 5089 & 4711 & 6110 & 9794 & 6966 & 5870 & 12301 & 5852 & 4102 & 8952 & 8761 & 7068 & 6346 & 6058 \\
\hline Iceland & 11215 & 12872 & 8142 & 14821 & 10023 & 11149 & 13860 & 11207 & 8918 & 12754 & 12671 & $x(11)$ & 11499 & $x(13)$ \\
\hline Ireland & 8288 & 9983 & 10259 & $a$ & 10259 & 10111 & m & 8671 & $x(11)$ & $x(11)$ & 13229 & 9747 & 9439 & 8852 \\
\hline Israel & 7971 & $x(3,4,5)$ & $6025^{d}$ & $15400^{4}$ & $7987^{4}$ & $7987^{d}$ & m & $\mathrm{m}$ & 5267 & 13865 & 11003 & 7109 & m & m \\
\hline Italy & 8426 & 9258 & $x(5)$ & $\mathbf{x}(5)$ & 8969 & 9079 & m & 8831 & 4120 & 11285 & 11257 & 7352 & 9308 & 8539 \\
\hline Japan & 9105 & 10562 & $x(5)$ & $x(5)$ & $11715^{d}$ & $11147^{d}$ & $\mathbf{x}(5,6,9,10,11)$ & 10167 & $13806^{4}$ & $20758^{d}$ & $19289^{4}$ & $x(11)$ & 12120 & $x(13)$ \\
\hline Korea & 11047 & 11025 & $x(5)$ & $x(5)$ & 13247 & 12202 & $a$ & 11688 & 5817 & 11310 & 10109 & 8141 & 11143 & 10464 \\
\hline Latvia & 6672 & 6723 & 7049 & 7233 & 7123 & 6930 & 8235 & 6824 & 10693 & 10046 & 10137 & 8208 & 7595 & 7146 \\
\hline Luxembourg & 20892 & 21124 & 18580 & 20587 & 19808 & 20413 & 1588 & 20451 & 24769 & 51625 & 48907 & 41905 & 22430 & 21943 \\
\hline Mexico & 2874 & 2514 & 4098 & 4429 & 4224 & 3129 & 2 & 2998 & $x(11)$ & $x$ (11) & 8170 & 6404 & 3611 & $x(13)$ \\
\hline Netherlands & 8478 & 12491 & 10329 & 14698 & 13241 & 12850 & 12655 & 10960 & 10543 & 19323 & 19286 & 12107 & 12730 & 11204 \\
\hline New Zealand & 7849 & 9409 & 11206 & 12544 & 11509 & 10383 & 9990 & 9266 & 11494 & 16015 & 15166 & 12207 & 10392 & $x(13)$ \\
\hline Norway & 13275 & 14486 & 16429 & 15768 & 16095 & 15401 & 16962 & 14353 & 16399 & 21129 & 20973 & 12363 & 15705 & 13947 \\
\hline Poland & 6757 & 6985 & 5775 & 7346 & 6655 & 6806 & 4424 & 6725 & 16373 & 9678 & 9687 & 7647 & 7400 & 6935 \\
\hline Portugal & 7380 & 9568 & $x(5)$ & $\mathbf{x}(5)$ & $9469^{4}$ & $9518^{d}$ & $\mathbf{x}(5,6,11)$ & 8533 & $\mathbf{x}(11)$ & $x(11)$ & $11766^{d}$ & $7477^{4}$ & 9153 & 8331 \\
\hline Slovak Republic & 6877 & 6282 & 6069 & 7658 & 7092 & 6660 & 7774 & 6747 & 8263 & 15998 & 15874 & 9845 & 8477 & 7334 \\
\hline Slovenia & 8542 & 9925 & 7971 & 6846 & 7230 & 8290 & 2 & 8406 & 3129 & 11140 & 10208 & 8075 & 8778 & 8338 \\
\hline Spain & 7320 & 8765 & 8716 & $10408^{d}$ & $9269^{4}$ & $9020^{4}$ & $x(4,5,6)$ & 8189 & 9088 & 13487 & 12605 & 9328 & 9130 & 8432 \\
\hline Sweden & 10853 & 11493 & 7749 & 16873 & 11331 & 11402 & 5102 & 11052 & 6777 & 25889 & 24417 & 11297 & 13289 & 11093 \\
\hline Switzerland & m & $\mathrm{m}$ & m & $\mathrm{m}$ & m & $\mathrm{m}$ & m & $\mathrm{m}$ & $\mathrm{m}$ & $\mathrm{m}$ & $\mathrm{m}$ & $\mathrm{m}$ & m & $\mathrm{m}$ \\
\hline Turkey & 4134 & 3491 & 3175 & 3919 & 3528 & 3511 & 2 & 3715 & $x(11)$ & $x$ (11) & 8901 & 7018 & 4652 & 4312 \\
\hline United Kingdom & 11630 & 10249 & 11660 & 9440 & 10798 & 10569 & a & 11028 & 8421 & 27931 & 26320 & 20526 & 13355 & 12473 \\
\hline United States & 11727 & 12693 & $x(5)$ & $\mathbf{x}(5)$ & 13474 & 13084 & 14294 & 12424 & $x(11)$ & $x(11)$ & 30003 & 26817 & 16518 & 15776 \\
\hline $\mathrm{OECD}$ average & 8631 & 9941 & 9119 & 11037 & 10196 & 10010 & 8927 & 9401 & 11022 & 16518 & 15656 & 11202 & 10520 & 9772 \\
\hline EU22 average & 8656 & 10175 & 9445 & 11428 & 10230 & 10105 & m & 9465 & 11090 & 16835 & 15998 & 11132 & 10555 & 9617 \\
\hline $\begin{array}{l}\text { Argentina } \\
\text { Brazil }\end{array}$ & \begin{tabular}{r|}
$m$ \\
3762
\end{tabular} & $\begin{array}{r}m \\
3789\end{array}$ & $\begin{array}{c}m \\
x(5)\end{array}$ & $\begin{array}{c}\mathrm{m} \\
\mathbf{x}(5)\end{array}$ & \begin{tabular}{r|}
$\mathrm{m}$ \\
$3986^{4}$
\end{tabular} & $\begin{array}{r}\mathrm{m} \\
3872^{d}\end{array}$ & $\begin{array}{r}m \\
\mathbf{x}(5,6)\end{array}$ & $\begin{array}{r}\mathrm{m} \\
3829\end{array}$ & \begin{tabular}{r|}
$\mathrm{m}$ \\
$\mathrm{x}(11)$
\end{tabular} & \begin{tabular}{r|}
$m$ \\
$x(11)$
\end{tabular} & $\begin{array}{r}m \\
14261\end{array}$ & $\begin{array}{r}\mathrm{m} \\
\mathrm{x}(11)\end{array}$ & $\begin{array}{r}\mathrm{m} \\
4451\end{array}$ & $\begin{array}{r}\mathrm{m} \\
\boldsymbol{x}(13)\end{array}$ \\
\hline China & $\mathrm{m}$ & $\mathrm{m}$ & $\mathrm{m}$ & $\mathrm{m}$ & $\mathrm{m}$ & $\mathrm{m}$ & $\mathrm{m}$ & $\mathrm{m}$ & $\mathrm{m}$ & $\mathrm{m}$ & $\mathrm{m}$ & $\mathrm{m}$ & $\mathrm{m}$ & $\mathrm{m}$ \\
\hline Colombia ${ }^{2}$ & 3178 & 2909 & $x(5)$ & $\mathbf{x}(5)$ & $2586^{4}$ & $2817^{d}$ & $x(5,6)$ & 2987 & $x(11)$ & $x(11)$ & 6369 & $x(11)$ & 3683 & $x(13)$ \\
\hline Costa Rica & m & $\mathrm{m}$ & $\mathrm{m}$ & $\mathrm{m}$ & m & $\mathrm{m}$ & m & $\mathrm{m}$ & $\mathrm{m}$ & $\mathrm{m}$ & m & $\mathrm{m}$ & $\mathrm{m}$ & m \\
\hline India & m & $\mathrm{m}$ & $\mathrm{m}$ & $\mathrm{m}$ & $\mathrm{m}$ & $\mathrm{m}$ & m & $\mathrm{m}$ & $\mathrm{m}$ & $\mathrm{m}$ & $\mathrm{m}$ & m & $\mathrm{m}$ & $\mathrm{m}$ \\
\hline
\end{tabular}

Fonte: OECD (2018), Education at a Glance 2018: OECD indicators, OECD Publishing, Paris. Página 254

Assim, dizer que o Brasil investe mais em educação que a média dos países da OCDE pode ser crível em termos da porcentagem do PIB destinado a esta pasta. Contudo, quando olhamos em termos absolutos, os investimentos do Brasil estão longe de atingir a média de países desenvolvidos. Isto se agrava quando consideramos o déficit educacional brasileiro, comparado aos países da OCDE, além das desigualdades sociais que caracterizam a realidade brasileira e que impactam o desenvolvimento escolar. 
O que pretendemos abordar com este exemplo é que a complexidade envolvida nas mensagens que circulam na mídia vai muito além do dualismo falso e verdadeiro. Sendo justos, é possível encontrar diversos materiais de mídia, incluindo mídias tradicionais, que também chamam a atenção do baixo investimento em educação no Brasil, quando considerados os valores empreendido por aluno. Com isto, é possível perceber que as produções da mídia podem ser variadas, mesmo em torno de um mesmo tema. Isto implica, novamente, que para aprofundarmos em um tema de interesse, não podemos nos restringir a uma única fonte. Além disso, é fundamental a busca por materiais usados como fonte das produções midiáticas.

Acreditamos que um posicionamento crítico e propositivo frente às produções da mídia não serão alcançados através da imposição de listas prescritivas sobre como proceder, muito menos a partir da classificação de notícias ditas falsas pelos grandes meios de comunicação. Defendemos que o melhor encaminhamento para lidar de maneira crítica com a mídia é através da educação, sobretudo por iniciativas sistematizadas na escola. $\mathrm{Na}$ próxima seção discutiremos algumas perspectivas da chamada "Educação para as mídias". Discutiremos algumas premissas gerais, buscando aproximar essas questões ao ensino de ciências.

\subsection{Educação e Comunicação: Perspectivas da "Educação para as Mídias"}

Considerando o alcance da mídia em nossa cultura, Kellner e Share (2008) destacam a importância da educação para a mídia, buscando reflexões e práticas voltadas à criação de possibilidades de exercícios de cidadania das pessoas. A busca por aproximar os campos da educação e da comunicação não é novidade, como afirma Pezzo: "[a]s interfaces entre as áreas de Comunicação e Educação têm ganhado destaque nos últimos anos, seja nas práticas cotidianas relacionadas à atuação profissional em ambos os campos, seja na produção acadêmica" (PEZZO, 2011, p. 18). Embora não possa ser considerada uma novidade, a mídia-educação é, de acordo com Bélvort e Belloni (2009), "um campo relativamente novo, com dificuldades 
para se consolidar, entre as quais a mais importante é, sem dúvida, sua pouca importância na formação inicial e continuada de profissionais da educação" (BÉLVORT \& BELLONI, 2009, p. 1082). Tomamos esta afirmação como uma justificativa e, ao mesmo tempo, inspiração para que nossa pesquisa esteja fundada fortemente na análise e reflexão de uma prática voltada à formação de Professores de Física.

Ao analisar as aproximações entre a área da educação e da mídia, mais especificamente a área emergente de mídia-educação, Kellner e Share (2008) identificam quatro tipos de abordagens. São elas:

- Medo da Mídia;

- Educação em arte midiática;

- Movimento de Alfabetização Midiática nos EUA;

- Alfabetização crítica da Mídia;

A abordagem conhecida como "medo da mídia" visa, de acordo com os autores, "a proteger ou inocular as pessoas contra os perigos da manipulação e dependência da mídia” (KELLNER \& SHARE, 2008, p. 698). Essa é uma abordagem protecionista que "pressupõe as audiências da mídia como vítimas passivas" (idem). Nossa leitura dos interessantes e importantes apontamentos de Chomsky (2013) nos levou a entender sua abordagem como se enquadrando nesta perspectiva, em especial por carregar em seu discurso, em nossa opinião, uma defesa "antimídia". Também interpretamos as iniciativas acerca das fake news citadas na seção anterior como estando dentro desta perspectiva, sobretudo por buscar a inoculação das pessoas com relação à mídia. Kellner e Share alertam, no entanto, que esta é uma abordagem limitada.

Se, por um lado, reconhecemos que a mídia contribui para a existência de muitos problemas sociais e às vezes até os causam, por outro lado, questionamos uma abordagem protecionista, pela sua tendência antimídia, que é demasiadamente simplista em relação à complexidade de nossas relações com a mídia e não leva em consideração o potencial que a pedagogia crítica e a produção de 
mídia alternativa oferecem para se dar poder às pessoas. (KELLNER \& SHARE, 2008, p. 699)

A abordagem que os autores chamaram de "educação em arte midiática" valoriza, sobretudo, as qualidades estéticas da mídia e das artes. A principal crítica dos autores a respeito desta abordagem é que ela é pouco problematizadora, isto é, que ela ensina aos alunos "habilidades técnicas para simplesmente reproduzir representações hegemônicas, sem provocar qualquer problematização, com pouca consciência de implicações ideológicas ou qualquer tipo de crítica social" (KELLNER \& SHARE, 2008, p.700).

Com relação ao movimento de Alfabetização midiática, os autores consideram que ela fez alguns avanços importantes. Esta abordagem busca incluir a cultura popular e múltiplas formas de mídia (música, vídeo, internet, anúncios, etc), e, ao mesmo tempo, ainda trabalhar dentro de uma tradição de alfabetização na forma impressa (KELLNER \& SHARE, 2008, p. 701). Os autores entendem, contudo, que esta abordagem não é o suficiente para uma "reconstrução democrática da educação e da sociedade" (idem). Defendem, então, um componente crítico para a alfabetização midiática. Este componente deve "transformar a alfabetização em uma exploração do papel da linguagem e da comunicação para definir relações de poder e dominação". Esta preocupação com as relações de poder e dominação vem de um entendimento de que nos discursos da mídia "vivem noções ideológicas profundamente embutidas, de supremacia branca, patriarcalismo capitalista, classismo, homofobia e outros mitos opressivos" (KELLNER \& SHARE, 2008, p. 701). Esta abordagem, alfabetização crítica da mídia, da qual os autores são partidários, inclui aspectos das três abordagens anteriores, mas "enfocando a crítica ideológica e analisando a política de representação das dimensões cruciais de gênero, raça, classe e sexualidade na economia política e nas relações sociais das importantes empresas de mídia" (KELLNER \& SHARE, 2008, p.702).

Ainda no prefácio da terceira edição de seu livro "O que é MídiaEducação", publicado originalmente em 2001, Maria Luiza Belloni (2009) 
destaca que embora seus escritos tenham se concretizado no final do século XX, não houve na virada de milênio avanços significativos na mídiaeducação no Brasil. Embora destaque experiências singulares importantes, Belloni afirma que "em níveis oficiais de ensino, na escola básica como no ensino superior, especialmente na formação de Professores, a mídiaeducação continua ignorada e ausente" (BELLONI, 2009, p. xi). Destaca, ainda, as mudanças tecnológicas incríveis que sofreram os processos de comunicação. Salienta especialmente a presença dos computadores pessoais, que "permite a cada indivíduo em particular entrar no ciberespaço" (BELLONI, 2009, p. xii).

Belloni (2009) considera que a "revolução tecnológica" decorrente do progresso técnico nas telecomunicações e na informática têm desdobramentos importantes. Por um lado, a autora afirma que esta "revolução", no papel das Novas Tecnologias de Informação (TIC), especialmente a Internet, abre novas possibilidades, democratizando o acesso à cultura e à participação. Por outro lado, essas novas maneiras de interação e informação "criam novos desejos e necessidades, são poderosos meios de publicidade e podem significar perigos de adição e de deslocamento ou fuga da realidade para crianças e adolescentes" (idem). De acordo com a autora este novo cenário traz consigo novos desafios para a mídia-educação, que deve aprender a lidar com:

i) Uma cultura midiática jovem, muito mais interativa e participativa;

ii) Fronteiras menos precisas entre uma elite produtora de mensagens e a massa de consumidores típicas de mídias de massa;

iii) Novos modos de perceber o mundo e aprender;

iv) Novas formas de fazer política e significativas possibilidades democráticas (BELLONI, 2009, p.xiii)

Esses desafios podem gerar potencialidades, que dependerão, em alguma instância, do tipo de relação que os jovens desenvolverão com as mídias: "uma direção mais democrática, crítica e criativa dependerá, em 
grande parte, das oportunidades de mídia-educação oferecidas à nova geração" (BÉVORT \& BELLONI, 2009).

Não são poucos os desafios colocados à mídia-educação. Além do já citado déficit relacionado à formação inicial e continuada dos profissionais de educação, Bévort e Belloni (2009, p. 1082-1083) destacam outros cinco obstáculos importantes:

i) Ausência de preocupação com a formação das novas gerações para a apropriação crítica e criativa das novas tecnologias de informação e comunicação (TIC);

ii) Indefinição de políticas públicas e insuficiência de recursos para ações e pesquisas;

iii) Confusões conceituais, práticas inadequadas, "receitas prontas" para a sala de aula, em lugar da reflexão sobre o tema na formação de educadores;

iv) Influência de abordagens baseadas nos efeitos negativos das mídias que tendem a baní-las da educação, em lugar da compreensão das implicações sociais, culturais e educacionais;

v) Integração das TIC à escola de modo meramente instrumental, sem a reflexão sobre mensagens e contextos de produção.

O item iii nos chama atenção especial. Nossa pesquisa é em grande medida tributária de um contexto concreto de desenvolvimento em sala de aula. Não será nosso intuito buscar consenso ou "receita pronta" sobre como abordar as questões da mídia no ensino de ciências. Chama a atenção também o obstáculo referido no item iv que está associado à abordagem que Kellner e Share chamaram de "medo da mídia".

Bévort e Belloni (2009) destacam ainda a atuação de organizações internacionais interessadas na educação para as mídias, particularmente a 
$\mathrm{UNESCO}^{16}$. As autoras afirmam que a UNESCO faz referências à educação para as mídias desde a década de 1960 . O tema continua presente e pode ser encontrado em documentos mais recentes, já da primeira década deste século. Ao olhar para o papel da UNESCO na discussão da mídia educação, as autoras dão destaque especial à reunião em Grunwald (Alemanha Ocidental), na qual representantes de 19 países adotaram uma Declaração comum sobre a importância das mídias e a obrigação dos sistemas educacionais de ajudarem os cidadãos a melhor compreenderem esses fenômenos. A respeito desta declaração as autoras afirmam o seguinte:

A Declaração de Grünwald parte da importância crescente das mídias na sociedade, especialmente nas novas gerações, e enfatiza a necessidade de ações e políticas de mídia-educação como componente básico e condição sine qua non da formação para a cidadania. Mídia-educação é definida como uma formação para a compreensão crítica das mídias, mas também se reconhece o papel potencial das mídias na promoção da expressão criativa e da participação dos cidadãos, pondo em evidência as potencialidades democráticas dos dispositivos técnicos de mídia. (BÉVORT \& BELLONI, 2009, p.1087).

Um novo marco para a mídia-educação, segundo as autoras, foi a conferência internacional "Educando para as mídias e para a era digital", realizada pela UNESCO em Viena, no ano de 1999. Além de considerar os avanços técnicos que tornaram as pessoas muito mais usuárias do que espectadoras da mídia, Bévort e Belloni (2009) afirmam que a mídiaeducação também precisava incorporar os efeitos culturais, educacionais e sociais presentes no Estatuto da Criança e do Adolescente, promulgado pela ONU em 1989. Para as autoras, a conferência em Viena foi uma reafirmação da conviç̧ão de que

[...] mídia-educação e a participação das crianças e adolescentes são caminhos necessários e simultâneos para a realização efetiva da Convenção Internacional dos Direitos da Criança e do Adolescente, especialmente os direitos relacionados à liberdade de

\footnotetext{
${ }^{16}$ Organização das Nações Unidas para a Educação, a Ciência e a Cultura.
} 
expressão (artigo 13), à informação (artigo 17) e à participação em decisões sobre assuntos que lhes dizem respeito (artigo 12) (BÉVORT \& BELLONI, 2009, p. 1093).

As autoras identificam algumas particularidades relacionadas à mídia-educação de acordo com os diferentes países que participaram da conferência em Viena, em particular uma diferença tributária da condição econômica dos países: os ricos destacam "objetivos de formação de indivíduos críticos, independentes e participativos" (BÉVORT \& BELLONI, 2009, p.1093), enquanto os pobres, incluindo o Brasil, "reafirmam a importância da mídia-educação para a formação da cidadania em toda a comunidade, para a democratização e justiça social” (idem). Essa busca por democratização e justiça social no contexto brasileiro de mídia-educação é devida, em partes, ao marco inicial mais significativo, de acordo com Pezzo (2016), dos esforços voltados à formação para uma relação crítica com a mídia no país, em grande medida tributária da atuação da União Cristã Brasileira de Comunicação Social (UCBC), fundada em 1969 no contexto da ditadura militar e meses após o Ato Institucional n5 (AI5). Pezzo (2016) afirma que a UCBC "configurou-se como espaço de encontro de lideranças da Igreja e de movimentos populares, bem como de profissionais e pesquisadores, articulados a partir do princípio da oposição ao autoritarismo e de defesa da liberdade de expressão" (PEZZO, 2016, p.37). A despeito dessa sutil e, ao mesmo tempo, profunda diferença de perspectiva entre os países ricos e pobres, Bévort e Belloni (2009) destacam algumas tendências comuns encontradas nos documentos relativos à conferência de Viena:

- Mídia-educação deve emanar dos interesses dos estudantes.

- Mídia-educação significa pensamento crítico e deve levar à construção de competências de análise crítica.

- A produção de mensagens pelos estudantes é um elemento essencial para a construção do pensamento crítico e da expressão.

- Mídia-educação é necessária à participação e à democracia, ou seja, é fundamental para a cidadania. 
- Mídia-educação deve considerar que a globalização, a desregulação e a privatização das mídias levaram à necessidade de novos paradigmas de educação.

- Mídia-educação deve incluir todas as mídias, não mais focalizar apenas ou principalmente as mídias impressas, mas deve incluir múltiplas "alfabetizações (literacies)".

(UNESCO, 1999 apud BÉVORT \& BELLONI)

As autoras destacam, ainda, alguns obstáculos apontados na conferência que dificultariam o desenvolvimento da mídia-educação, relacionados ao insuficiente apoio de organismos oficiais, ausência de políticas públicas, e desinteresse da própria mídia em ações relacionadas à mídia-educação. Com relação a este último ponto, as autoras afirmam que os relatos da conferência foram cautelosos. As autoras consideram que a falta de empenho dos sistemas midiáticos em colaborar com ações de mídiaeducação é óbvia, uma vez que

as mídias de massa, baseadas na publicidade comercial, precisam de audiências desavisadas, distraídas, embevecidas pelas aventuras dos heróis das ficções ou embaladas por informações fragmentadas, prontas a aceitar sem pensar os argumentos de mensagens publicitárias animadas, coloridas, envolventes. Os sistemas de mídia necessitam de públicos não-educados, acríticos, cujo tempo de cérebro suas mensagens preenchem (BÉVORT \& BELLONI, 2009, p. 1094)

Outro encontro que parece ter sido um marco na área ocorreu em Paris, no ano de 2007, em comemoração aos 25 anos de Grumwald. As autoras destacam o que chamaram de Agenda de Paris, organizadas em quatro eixos temáticos. Reproduzimos abaixo a seleção feita pelas autoras do documento da UNESCO.

I - Desenvolvimento de programas integrados em todos os níveis de ensino

1. Adotar uma definição inclusiva da mídia-educação que vá além da simples distinção entre educação pelas mídias e educação para as mídias e considere as mutações trazidas pelo desenvolvimento 
das TIC: novas competências, novos modos de aprender, ligados ao domínio da informação e à comunicação interativa, ou seja, à apropriação criativa e crítica das tecnologias e seus usos como meios de expressão.

2. Reforçar os vínculos entre a mídia-educação, a diversidade cultural e o respeito aos direitos humanos, no sentido de contribuir para a emancipação e a responsabilização dos indivíduos, como parte integrante da formação para a cidadania.

3. Definir as competências a construir, organizando o ensino em todos os níveis, de modo transversal e interdisciplinar, e os sistemas de avaliação, de alunos e professores, visando à melhor pertinência e eficácia.

\section{II - $A$ formação de professores e a sensibilização dos diferentes atores da esfera social}

4. Integrar a mídia-educação à formação inicial dos professores, considerada como elemento-chave do dispositivo, devendo integrar ao mesmo tempo as dimensões conceituais e os saberes práticos e estar baseada no conhecimento das práticas midiáticas dos jovens.

5. Desenvolver métodos pedagógicos apropriados e ativos, sem receitas prontas, que implicam uma evolução no papel do professor, uma maior participação dos alunos e relações mais estreitas entre a escola e o mundo exterior.

6. Mobilizar todos os atores do sistema escolar, técnicos, administradores, etc., no sentido de sensibilizar a todos a assumir responsabilidades e legitimar as ações.

7. Mobilizar os outros atores da esfera pública, pois a mídiaeducação

não se limita aos espaços escolares, mas diz respeito também às famílias, associações e profissionais de mídia.

8. Inscrever a mídia-educação no quadro da educação ao longo da vida, pois ela diz respeito também aos adultos, podendo ser vetor de uma melhor qualidade da educação continuada.

III - A pesquisa e suas redes de difusão 
9. Desenvolver a mídia-educação e a pesquisa no ensino superior, em quadros interdisciplinares e em relação com estudos sobre inovações pedagógicas e sobre o impacto das TIC no ensino e na formação.

10. Criar redes de intercâmbio entre pesquisadores, de modo a capitalizar e compartilhar hipóteses e resultados de pesquisa, para contribuir à mudança de escala necessária à mídia-educação. Os resultados deveriam levar à elaboração de recomendações éticas suscetíveis a compor uma Carta internacional.

\section{IV - A cooperação internacional em ações}

11. Organizar e tornar visíveis os intercâmbios internacionais, no sentido de difundir as "boas práticas" e os trabalhos existentes, para melhor apreender a diversidade de situações concretas.

12. Sensibilizar e mobilizar os atores políticos, notadamente os decisores de alto nível em todos os países.

(UNESCO, 2007 apud BÉVORT \& BELLONI, 2009, p. 1096-1097)

Nos chama especial atenção, tendo em vista os objetivos pretendidos nesta tese, o segundo eixo temático, que destaca a importância da formação de Professores. De acordo com Bévort e Belloni (2009), pela primeira vez, nos documentos oficiais internacionais deste tipo, "aparece entre as principais recomendações a prioridade ao ensino formal, como espaço privilegiado de ações de mídia-educação, à formação inicial de professores (condição sine qua non de realização desta prioridade) e à pesquisa integrada ao estudo de inovações pedagógicas (e não mais a estudos de recepção de mídias, de especialistas da comunicação)" (BÉVORT \& BELLONI, 2009, p. 1097). Parece-nos, então, que a preocupação na formação de Professores tendo em vista as questões envolvendo mídia e educação são ainda relativamente recentes, carecendo, portanto, de investimento teórico e prático. A este respeito, Mariana Pezzo (2016), pautada em várias referências, é taxativa ao afirmar que "é urgente a reflexão sobre a inserção da educação para as mídias nos cursos de formação inicial, especialmente nas licenciaturas" (PEZZO, 2016, p. 44). Entretanto, como afirmou Graça Caldas (2006), não se trata apenas de "ensinar os 
Professores a 'lerem' os jornais, mas sobretudo de possibilitar a eles, num primeiro momento, uma leitura do mundo para melhor compreenderem, eles próprios, o poder da mídia e o papel ocupado pelos diferentes veículos no espaço público" (CALDAS, 2006, p. 123).

Caldas (2006, p.124) chama a atenção de seus leitores para a inserção empresarial em projetos de mídia na escola.

Os grupos de mídia, principalmente os impressos: jornais e revistas, começaram a distribuir os encalhes de seus exemplares e a produzir versões direcionadas à sala de aula. Este movimento pela inserção do jornal e da revista na sala de aula, como prática pedagógica, ganhou força no início da década de 1990 e ainda hoje continua conquistando novos adeptos, como é o caso da revista Carta Capital, que lançou em outubro de 2005 sua versão pedagógica (CALDAS, 2006, p. 120)

Com relação a este tipo de inserção na escola, Mariana Pezzo (2011, p. 28) destaca que 63 dos 145 periódicos que compõem a Associação Nacional de Jornais (ANJ) mantinham, em 2009, programas formais de inserção de suas publicações nas escolas, sendo 27 na região sudeste. A autora ressalta que é necessário que se faça uma análise crítica dessas iniciativas, especialmente levando em conta as motivações econômicas que as impulsionam. A autora afirma que essas iniciativas "visam a formação de leitores não apenas no sentido geral, mas também - e talvez principalmente - a formação de futuros leitores para seus veículos” (PEZZO, 2011, p.28).

A seguir apresentamos algumas discussões relacionadas à educação para as mídias na área de ensino de ciências.

\subsection{Educação para as Mídias e o Ensino de Ciências}

Mariana Pezzo, já citada ao longo deste capítulo, é graduada em Comunicação Social - Jornalismo e tem se empenhado nos últimos anos à aproximação dos anseios da educação para as mídias e da educação em ciências. Pezzo desenvolveu sua dissertação de mestrado e tese de doutorado tendo como objeto de pesquisa a mídia e o ensino de ciências, focando, 
sobretudo, em produções jornalísticas. Atualmente Pezzo exerce a função de coordenadora executiva do Laboratório Aberto de Interatividade para Disseminação do Conhecimento Científico e Tecnológico (LABI), vinculado à Universidade Federal de São Carlos (UFSCar), que tem como objetivos gerais, de acordo com seus idealizadores, a "prática da divulgação científica pautada na interatividade; nas relações entre Ciência, Arte e Tecnologia; na realização de produtos em diferentes suportes e direcionados a públicos diversos; e na produção de conhecimento sobre as metodologias adotadas" 17 .

Em sua dissertação de mestrado, Pezzo (2011) analisou como se dão os processos de recontextualização e interpretação entre as reportagens da revista semanal Carta Capital e os textos dela decorrentes publicados em Carta na Escola, revista mensal que se propõe a oferecer a Professores do ensino médio subsídios para abordagem das atualidades em sala de aula. A autora classificou os textos das duas revistas de acordo com as áreas curriculares definidas nas Diretrizes Curriculares Nacionais para o Ensino Médio. Em Carta na Escola houve uma concentração maior de textos relacionados à área das Ciências da Natureza. Dos textos integralmente identificados com esta área, foi preponderante a busca por "abordagens favorecedoras da vinculação entre conceitos científicos e contextos socialmente relevantes, que apareceu em 4 [de um total de 6] dos conjuntos analisados" (PEZZO \& PIERSON, 2013, p. 3095). Além desta análise, a autora buscou identificar nos textos selecionados o potencial de concretização dos princípios e metas colocados pela abordagem CTSA (Ciência-Tecnologia-Sociedade-Ambiente). O objetivo de Pezzo não foi o de estabelecer um veredito sobre a qualidade do material analisado, mas a busca por compreensões acerca:

\footnotetext{
"das relações possíveis e produtivas entre os campos da Comunicação Social e da Educação; dos limites e potencialidades do uso de materiais de divulgação científica no ensino de ciências e, de modo mais abrangente, na formação científica em ambientes
}

\footnotetext{
${ }^{17}$ Retirado do site do LABI. Acesso através do link: http://www.labi.ufscar.br/quem-somos/. Acessado em $21 / 07 / 2017$ às 16 h04.
} 
formais e não formais de públicos com características diferenciadas; e do papel que o uso de materiais midiáticos voltados à veiculação de informações sobre Ciência e Tecnologia pode exercer na superação de desafios relacionados a abordagens de ensino de ciências pautadas nas inter-relações entre Ciência, Tecnologia, Sociedade e Ambiente" (PEZZO, 2011, p.112)

Em sua tese de doutorado, Pezzo (2016) focou suas discussões na Formação de Professores - ainda tendo o ensino de ciências como referência. Como tentamos salientar ao longo deste capítulo, a formação de Professores tem sido uma recomendação (e condição!) para o fortalecimento das discussões sobre educação para a mídia. A autora buscou compreender como Professores em formação em cursos de Licenciatura em Ciências Biológicas, Física e Química relacionam-se com a mídia e quais são suas expectativas em relação à inserção das produções midiáticas no ambiente escolar. Para isto, fez uma análise detalhada de materiais produzidos pelos próprios licenciandos (sínteses individuais e trabalhos em grupo), no contexto de uma disciplina intitulada: "Estratégias para a utilização de notícias de Ciências e Tecnologia no Ensino de Ciências".

Como salientamos no início deste capítulo, e buscamos reforçar ao longo dele, a mídia está intimamente ligada à nossa organização social contemporânea. Olhando especificamente para o papel das notícias, Jarman e McClune afirmam que "uma vez que a notícia é evidente no domínio público, a ciência nas notícias também é de domínio público" (JARMAN \& McCLUNE, 2007, p. 14). Assim, defendem que os objetivos da Alfabetização Científica devem estar relacionados, também, à leitura crítica desses materiais de domínio público. Acreditam que uma maneira de preparar os estudantes para seus futuros é engajando-os e preparando-os para a leitura crítica de notícias relacionadas à ciência enquanto estão na escola, visto que essa fonte (dos noticiários) será o principal meio pelo qual terão contato com os assuntos da ciência e assuntos sociais relacionados à ciência (idem).

Renata Ribeiro e Maria Regina Kawamura (2008) afirmam que a "interpretação de notícias sobre ciência e tecnologia veiculadas pelas 
diferentes mídias e a compreensão de seus significados e das implicações sociais, políticas e ambientais do desenvolvimento científico e tecnológico constituem algumas competências, apresentadas pelos Parâmetros Curriculares Nacionais para o Ensino Médio - PCNEM, a serem desenvolvidas até o final da escolaridade básica” (RIBEIRO \& KAWAMURA, 2008, p. 2). As autoras destacam a importância dada à busca de prover meios para que os estudantes possam se posicionar criticamente diante do mundo, emitindo juízos sobre as informações com as quais têm contato e a necessidade de participação ativa na transformação de sua realidade. Analisando os trabalhos de interface entre ensino de física e divulgação científica, as autoras constatam que essas pesquisas concluem (ou objetivam) que os materiais de divulgação científica contribuem para a formação do espírito crítico dos estudantes, para um olhar crítico sobre a realidade (idem). A tese central das autoras é que "esse olhar crítico para a realidade está relacionado tanto ao processo de produção do conhecimento científico e suas aplicações (foco na ciência e tecnologia) quanto ao de produção das próprias informações sobre ciência e tecnologia e sua veiculação pelos diferentes meios de comunicação (foco na mídia impressa)" (ibdem). As autoras defendem que a articulação e problematização desses dois focos são fundamentais para uma reflexão sobre as formas de incorporação dos materiais de divulgação científica em nossas aulas. Elas concluem que o trabalho com textos de divulgação científica em sala de aula, visando a formação do espírito crítico dos alunos, deve

[...] além de possibilitar discussões a respeito das relações entre ciência, tecnologia e sociedade, dos impactos sócio-ambientais decorrentes do desenvolvimento científico e tecnológico, da política científica nacional etc., também precisa proporcionar uma reflexão crítica e analítica sobre os próprios meios de comunicação, o que envolve o desvelamento de ideologias, o reconhecimento dos recursos utilizados para atrair o leitor e suas influências sobre os conteúdos das informações noticiadas, as estratégias de narrativas e linguagem, a estrutura textual e as características dos textos informativos etc. (RIBEIRO \& KAWAMURA, 2008, p. 11) 
Com relação ao primeiro foco, olhar para a ciência na divulgação científica, as autoras ressaltam as pesquisas que criticam as visões limitadas sobre ciência veiculadas nos textos de divulgação, em especial pautados em uma "mitologia dos resultados", isto é, textos que representam o fazer científico apenas por seus produtos, "ignorando os processos (históricos, sociais e culturais) e os procedimentos (metodológicos) inerentes à atividade científica; na compreensão dos resultados das pesquisas como decorrentes de procedimentos cumulativos e finalistas [...]" (RIBEIRO \& KAWAMURA, 2008, p.4)

Em um trabalho em que usamos alguns instrumentos metodológicos da Análise de Discurso para refletir sobre aspectos relacionados à Natureza da Ciência em textos jornalísticos sobre a "descoberta" do bóson de Higgs, concluímos que havia nos textos analisados uma imagem subentendida de ciência como um desvelar da realidade, como um empreendimento que alcança gradativamente as verdades sobre a Natureza (CARDOSO et al, 2015). Outra crítica que Ribeiro e Kawamura identificam na literatura é a contribuição dos materiais de divulgação científica na manutenção do chamado "mito da neutralidade da ciência". As autoras afirmam que as questões relacionadas à neutralidade da ciência aparecem nos trabalhos presentes na literatura, dentre outras coisas, através da "ausência de visões contraditórias em matérias e artigos sobre ciência" (RIBEIRO \& KAWAMURA, 2008, p. 5). Mariana Pezzo, em palestra ${ }^{18}$ proferida no XXII SNEF ocorrido em Janeiro de 2017 na cidade de São Carlos, também reforça a crítica relacionada à ausência de contraditório, especialmente em matérias jornalísticas sobre ciência e tecnologia. A jornalista Mônica Teixeira entende que há uma crença de que a verdade da ciência não comporta versões e, assim, o jornalismo científico é isentado de cumprir o "mandamento que interdita a matéria feita a partir de uma única fonte [...]" (TEIXEIRA, 2002, p. 134). Jarman e McClune ponderam, no entanto, ao afirmarem que algumas das fontes usadas pelos jornalistas, em especial quando se trata de

\footnotetext{
${ }^{18}$ É possível assistir à palestra usando a plataforma YouTube, através do link: https://www.youtube.com/watch?v=VcIT 2WYEeE. Último acesso em 21/07/2017 às 19 h56.
} 
revistas especializadas, são revisadas por pares: “[o] fato de a pesquisa ser revisada por pares oferece aos meios de comunicação uma garantia de confiabilidade" (JARMAN \& McCLUNE, 2007, p. 45, tradução nossa).

Ribeiro e Kawamura, ao olharem para o segundo foco que propuseram, isto é, para as particularidades dos próprios meios de comunicação e de sua linguagem, focam em três características que são alvo de críticas de jornalistas, cientistas e pesquisadores da área de ensino: Sensacionalismo; Fragmentação; Simplificação. De acordo com as autoras, o sensacionalismo é um conceito polêmico que "apresenta graduações e facetas. Pode englobar desde a utilização de recursos, como suspense e adjetivação, em manchetes ou chamadas, por exemplo, até a extrapolação do real e espetacularização dos fatos" (RIBEIRO \& KAWAMURA, 2008, p. 7). As autoras defendem o valor pedagógico que reportagens sensacionalistas podem ter.

\footnotetext{
Talvez uma reportagem sensacionalista possa ser um agente que proporcione a problematização de um dado tema científico em ambiente de sala de aula, por exemplo. Ou possa fomentar discussões a respeito dos processos de produção dos noticiários sobre ciência. Ou, ainda, possibilite, em conjunto com outros tipos de materiais, a construção de um olhar mais crítico sobre os resultados e os processos da ciência e também sobre a mídia (RIBEIRO \& KAWAMURA, 2008, p. 7).
}

Teixeira (2002) afirma de maneira taxativa que o jornalismo científico é sensacionalista. Afirma que "é difícil para qualquer jornalista não praticar o sensacionalismo: o acontecimento que não causa espanto, uma sensação, não preenche os requisitos da notícia” (TEIXEIRA, 2002, p. 140). A jornalista destaca que alguns de seus colegas, aderindo à palavra do cientista sem questioná-la, relatam o que vale em condições especiais de um experimento, por exemplo, sem dizer nada sobre essas delimitações de estudo do problema, isto é, tomam a parte como um todo: "afirmar a parte pelo todo, sem mencionar que a parte não é o todo: eis a maneira pela qual a ciência 'traduzida' pelos jornalistas faz-se sensacionalista” (idem). 
Com relação à simplificação, Ribeiro e Kawamura afirmam que este processo está relacionado à tentativa de passar de uma linguagem complexa, como a da ciência, para um texto ou discurso acessível ao público de não especialistas. O problema central da simplificação, de acordo com as autoras, "é o comprometimento da precisão dos conceitos e da linguagem científica”. Embora não aprofundem nesta temática, as autoras indicam que há correntes que entendem a atividade da divulgação da ciência não como uma tradução de uma linguagem complexa para uma linguagem acessível ao público geral, mas como sendo um processo de construção de um novo saber.

A transformação do conhecimento científico com fins de ensino e divulgação não constitui simples "adaptação" ou mera "simplificação" de conhecimento, podendo ser então analisada na perspectiva de compreender a produção de novos saberes nesses processos" (MARANDINO, 2004 apud RIBEIRO \& KAWAMURA, 2008, p. 8, grifo das autoras).

Com relação à fragmentação, Ribeiro e Kawamura (2008, p.8) destacam que as informações sobre ciência e tecnologia que recaem nesta categoria são dispersas, descontextualizadas, consolidam uma visão única, e reproduzem os acontecimentos de maneira superficial.

\begin{abstract}
A fragmentação é uma característica marcante das informações. $\mathrm{O}$ poder de reprodução dos fatos pela mídia, a agilidade com que os acontecimentos são relatados e a velocidade de circulação das informações são fatores que contribuem para a chamada fragmentação da realidade. Ao leitor cabe selecionar e escolher entre as informações disponíveis aquelas que forem de seu interesse. Cabe também ao leitor articular as peças dessa realidade relatada de maneira fragmentada (RIBEIRO \& KAWAMURA, 2008, p.9)
\end{abstract}

Além dessas características discutidas acima, poderíamos nos perguntar sobre a parcialidade das notícias, como aquelas destacadas por Chomsky (2013). Jarman e McClune (2007) afirmam que "a objetividade é uma expressão e ao mesmo tempo um ideal e método jornalístico" (JARMAN \& McCLUNE, 2007, p. 48, tradução nossa). Embora apontem que a 
objetividade seja um ideal jornalístico, os autores reforçam que toda mensagem midiática está embebida de valores e pontos de vista. Entender a construção de notícias é, de acordo com os autores, um objetivo/princípio (tenet) do letramento midiático (idem). Considerando que não há objetividade nem neutralidade na construção de um texto, os autores defendem ser problemática a afirmação de que uma reportagem seja tendenciosa, uma vez que isso implicaria que de alguma forma poderíamos ter construções imparciais (que não fossem tendenciosas), o que para eles "é simplesmente impossível” (ibdem). Em outras palavras, não há como desvencilharmo-nos de nossas visões de mundo em qualquer que seja nossa atividade. Claramente, contudo, é necessário que reconheçamos, como nos chamou a atenção Paulo Freire, que as mensagens da mídia estão relacionadas ao exercício do poder. Além disso, é fundamental que consideremos que este exercício do poder se dá, recorrentemente, a partir da manipulação das pessoas, seja através da seleção enviesada de dados, como discutimos na seção 3.2, seja a partir da disseminação intencional de narrativas que não correspondem com a realidade, o que tem sido chamado de Fake News.

Com relação às produções midiáticas que envolvem a Ciência, parecenos razoável considerar que o jornalista envolvido na construção de manchetes científicas tenha algum conhecimento sobre ciência. Não sabemos dimensionar, no entanto, o quanto esse profissional deveria investir em sua formação científica. Mesmo considerando a vaguidão desta nossa afirmação, ela nos serve para levantar a seguinte questão: Será que a solução de muitos dos problemas encontrados na divulgação científica, e no jornalismo científico mais especificamente, seria a formação científica dos profissionais que trabalham nesta área? No limite, se os próprios cientistas tomassem para eles a responsabilidade de falar para o grande público esses problemas seriam amortizados? Não acreditamos que este caminho teria êxito. Como afirma Teixeira (2002, p.141), “o jornalista não precisa conhecer todos os assuntos para poder perguntar sobre eles". A autora defende que o imprescindível no jornalismo é "seus profissionais conhecerem como se usa o 
contraditório para construir versões mais precisas, em que mais vozes encontram expressão" (idem). Conclui dizendo que "se o jornalista que cobre ciência é um bom jornalista, não se preocupem: a qualidade da divulgação científica virá por si” (ibdem). Neste sentido, notamos a importância de olhar não apenas para o conhecimento da ciência, mas para as condições de produção das notícias sobre a ciência, como apontaram Ribeiro e Kawamura (2008).

Outro problema encontrado na literatura é a complexidade envolvida nos estudos que buscam identificar de quais maneiras as notícias sobre ciências são recepcionadas pelas variadas audiências a que são dirigidas. Jarman e McClune (2007, p. 54) afirmam, de acordo com teorias correntes, que o espectador, ouvinte, leitor ou internauta longe de ser um receptor passivo de texto de notícias, deve ser reconhecido como um ser ativo no processo de construção de significado. Ou seja, eles defendem que o significado é criativamente construído na interação entre o indivíduo e o texto. Assim, não só a produção de notícias é um processo de construção, mas a recepção de notícias também é um processo de construção. Acreditamos que estas considerações reforçam ainda mais a importância de criamos possibilidades concretas para as pessoas envolvidas no processo de educação para a mídia possam desenvolver não só capacidade crítica de leitura de materiais midiáticos, mas também que desenvolvam aspectos criativos de interação com esses meios como forma de ler e se relacionar com o mundo do qual participam. Assim, concluímos este capítulo com uma afirmação da autora que está na epígrafe, Graça Caldas (2006).

Utilizar a mídia na escola é o primeiro passo para a leitura do mundo. Em contrapartida, é essencial que o exercício cotidiano no uso da mídia na sala de aula não se limite à leitura de jornais, revistas ou dos veículos eletrônicos. Para se ler o mundo a partir dos olhares dos outros, é fundamental que seus leitores aprendam antes a ler o mundo em que vivem, por meio da construção de suas próprias narrativas. Só assim será possível a construção do conhecimento, a transformação do educando em sujeito de sua própria história. A aquisição do pensamento crítico é resultado da 
inserção e percepção direta do aluno como agente mobilizador na sua realidade (CALDAS, 2006, p. 129).

No próximo capítulo apresentaremos um estudo de caso, cuja intenção foi aproximar as fundamentações teóricas discutidas nos capítulos 2 e 3 à História da Ciência. O objetivo deste estudo de caso foi o de desenvolver uma atividade em sala de aula, que foi ministrada para as turmas de EDC e PE1 no IFSP, de modo que os licenciandos pudessem avaliar uma possível abordagem, na prática, das questões educacionais debatidas durante as disciplinas mencionadas acima. Este estudo de caso foca na repercussão que dois grandes jornais, The New York Times e The Times London, deram às observações do Eclipse Solar Total ocorrido em 1919. Selecionamos três reportagens publicadas neste ano. Cada uma delas foi analisada separadamente e, por fim, buscamos algumas comparações entre essas produções. 


\section{Capítulo 4}

\section{Intermezzo: Análise de textos}

\section{jornalísticos publicados no contexto}

\section{das observações do Eclipse Solar Total de 1919}

Neste capítulo realizaremos uma análise das reportagens que apresentamos nos cursos de EDC e PE1 como proposta de atividade. O objetivo foi apresentar uma metodologia possível de abordagem de materiais de mídia em aulas de física, aproximando essa abordagem de questões sociais em uma perspectiva histórica.

Optamos por trabalhar com materiais históricos da mídia. A partir de três textos publicados nos jornais The Times e The New York Times, buscamos compreender o contexto social, político e científico relacionados às observações do Eclipse Solar Total em 29 de maio de 1919, e sua repercussão em novembro deste mesmo ano, quando foram publicados os resultados da observação em uma reunião conjunta entre Royal Society e Royal Astronomical Society.

O The Times é o jornal diário mais antigo da Inglaterra, tendo sido fundado em 1785 por John Walter I'19. Entre 1785 e 1788 foi chamado de "Daily Universal Register", quando só então passou a ser denominado como é hoje. Na apresentação que o jornal faz de si mesmo, na seção "About US", eles destacam que na primeira edição do The Times, John Walter I explicou que "como uma mesa bem coberta, [o jornal] deve conter algo adequado a todos os 'paladares', incluindo política, relações exteriores, assuntos de

\footnotetext{
${ }^{19}$ Informações retiradas do próprio site do jornal The Times. Disponível em: https://www.thetimes.co.uk/static/about-us/?region=global
} 
comércio, julgamentos legais, propagandas e 'diversões"'. Destacam, ainda, que "em seu tom e neutralidade política, Walter reservava-se o direito do jornal de 'censurar ou aplaudir qualquer um [partido político]' e de encobrir questões controversas com respeitoso 'argumento justo"' (THE TIMES). Como discutimos nos capítulos anteriores, não existe neutralidade possível na prática jornalística. Entendemos que a consideração de que Walter "reservava-se o direito de censurar ou aplaudir qualquer um" deixa claro como o jornal necessariamente se posiciona diante de políticas específicas, em claro exercício de poder.

Chamamos atenção ao posicionamento pacificador do jornal pósprimeira guerra mundial, especialmente na década de 30. O historiador Alan Foster (1981) defende que tal posicionamento se deu a partir das reflexões do jornal sobre o tratado de Versalhes. Foster (1981) aponta que essas reflexões indicavam que o acordo de Versalhes baseou-se em uma série de ilusões:

A primeira delas foi que a tranquilidade na Europa poderia ser assegurada pela extensão geral da democracia representativa. [...] A segunda grande ilusão sobre a qual Versalhes fora construída foi a crença de que uma ordem européia estável poderia ser criada por meio da aplicação universal do princípio da autodeterminação nacional. [...] A terceira grande ilusão para informar o assentamento foi a esperança que um novo sistema europeu estável poderia ser fabricado sem a participação da Alemanha ou da Rússia. (FOSTER, 1981, pp. 442-443).

A partir deste posicionamento crítico ao tratado de Versalhes, Foster (1981) afirma que o jornal The Times "opôs-se à construção de uma aliança geral anti-alemã na década de 1930, que necessariamente teria incluído a União Soviética, não por causa de uma preocupação com o perigo superior supostamente apresentado pela Rússia, mas por uma objeção teórica geral ao surgimento na Europa de dois sistemas de alianças opostas que poderiam terminar em uma repetição da catástrofe de 1914 [primeira guerra mundial] (FOSTER, 1981, p. 444). 
A seleção dos artigos que fizemos do The Times é, a nosso ver, uma representação pela busca de pacificação entre ingleses e alemães, em um período em que a primeira guerra havia sido recém-terminada e o clima de hostilidade entre esses países ainda estava em alta, o que influenciou também as relações internacionais da ciência. Em particular, selecionamos duas reportagens que versam sobre os desdobramentos das expedições inglesas que observaram um eclipse solar total em maio de 1919, na Ilha Príncipe e em Sobral. Em novembro deste mesmo ano os astrônomos ingleses publicaram os resultados das expedições, que corroboravam a teoria da relatividade geral de Einstein, um físico alemão. O historiador da Ciência Antonio Augusto Passos Videira (2005) afirma que o jornal inglês montou uma longa estratégia de propaganda das expedições inglesas que testaram a teoria de um alemão.

Para o eclipse de Sobral, a participação de Eddington foi decisiva, não apenas pela influência que exerceu no comitê permanente de eclipses, mas também porque organizou uma propaganda na imprensa que foi muito favorável à recepção das idéias de Einstein. O cientista inglês, ajudado por colegas e membros da imprensa, montou uma cuidadosa estratégia de propaganda nos jornais britânicos. Durante dez meses, o The Times publicou vários artigos tratando do eclipse de 1919 (VIDEIRA, 2005, p. 85, grifos nossos).

O historiador Alistair Sponsel (2002), ao comentar particularmente a reportagem do The Times intitulada "Revolution in Science", que discutiremos a seguir, afirma que "ao invés de ser um caso inexplicável de presciência editorial, era esperada a cobertura do The Times da reunião conjunta dada a natureza de suas reportagens prévias das expedições do eclipse” (SPONSEL, 2002, p.445). Ainda de acordo com o historiador, o artigo "Revolution in Science" "cita cinco fontes diferentes para sua cobertura antes da reunião conjunta" (SPONSEL, 2002, p. 446). A reportagem foi escrita pelo zoologista Peter Chalmers Mitchell. Sofia Basilio (2018, p.64) afirma que Mitchell, assim como Einstein e Eddington, era um entusiasmado internacionalista. Assim, "compartilhava do desejo de 
Eddington de ressaltar a vitória que era uma expedição britânica confirmar uma teoria alemã no final de uma guerra" (BASILIO, 2018, p.64).

Já o jornal The New York Times, do qual também selecionamos uma reportagem acerca dos desdobramentos das observações do eclipse de 1919, foi fundado em 1851 por Henry Jarvis Raymond e George Jones. Após um período de crise, o jornal foi comprado por Adolph Ochs, de ascendência alemã (KLEFF, s/d), em 1896. Foi Ochs quem consolidou a linha editorial adotada ainda hoje pelo slogan "All the News That's Fit to Print" (todas as notícias que podem ser impressas se encontram no NYT)20. O jornal é controlado pela mesma família (Ochs-Sulzberger) desde então. Eles detêm $88 \%$ das ações ordinárias, ou seja, com direito a voto ${ }^{21}$. De acordo com a Encyclopedia Britannica ${ }^{22}$, Ochs manteve e enfatizou a boa cobertura existente de notícias internacionais. Um exemplo deste tipo de cobertura foi feita através de um telegrama direto de Londres, um dia após a reunião conjunta entre Royal Society e Royal Astronomical Society, na qual o New York Times fazia circular nos EUA a notícia sobre os resultados que corroboravam a teoria de Einstein. De acordo com o historiador da ciência Marshall Missner (1985), a fama de Einstein na América se deveu, principalmente, à imprensa: Embora não haja razão para acreditar que houvesse uma causa
única para a fama de Einstein, a imprensa americana foi o
instrumento que transformou Einstein em uma celebridade
(MISSNER, 1985, p. 268)

A principal tese do historiador é que um dos fatores preponderantes para a teoria de Einstein ter se tornado famosa e de interesse do público em geral, está relacionado à linguagem e à escolha de certas palavras que foram veiculadas pelos jornais. Missner apresenta algumas expressões utilizadas na divulgação da teoria da relatividade geral, que geravam interesse, seja

\footnotetext{
${ }^{20}$ The New York Times. History. Disponível em: https://www.nytco.com/company/history/our-history/

${ }^{21}$ Dados retirados da Revista EXAME. Disponível em: https://exame.abril.com.br/negocios/new-yorktimes-nao-esta-a-venda-diz-familia-ochs-sulzberger/

${ }^{22}$ Encyclopedia Britannica: The New York Times. Disponível em: https://www.britannica.com/topic/TheNew-York-Times
} 
pelo aspecto paradoxal, como a relatividade do espaço tempo, quanto pelo significado que elas apresentavam no contexto pós guerra, como o uso reiterado da palavra "revolução". Analisaremos, particularmente, a reportagem "Lights All Askell in the Heavens".

Há muito tempo é comum os historiadores escreverem a história da imprensa. Contudo, até a década de 1970 havia relutância em escrever a história por meio da imprensa (LUCA, 2008). Vale destacar que os jornais, assim como qualquer documento fonte, não podem ser encarados como fontes incontestáveis dos acontecimentos históricos, uma vez que é atravessado por subjetividades de diversas ordens, como procuramos salientar nos capítulos anteriores. Assim, o próprio jornal torna-se um objeto da pesquisa histórica (LUCA, 2008, p. 118). Com isto, não basta interpretarmos o texto escrito efetivamente, mas buscarmos entender o que não está escrito, que seja possível identificar à luz do contexto histórico. Isto foi feito em nossa análise através da confrontação dos materiais analisados com interpretações de historiadores da ciência sobre este episódio, que apresentaremos nas seções a seguir.

\subsection{Análise do texto "Lights all askew in the heavens", publicado no jornal The New York Times em 9 de Novembro de 1919}

Ao longo do texto, produzido no contexto em que os resultados das observações do Eclipse Solar Total de 1919 foram publicados, percebe-se alguns apelos ao sensacional. Em alguns pontos, esse apelo ao sensacional configura-se como uma extrapolação da realidade, em uma espetacularização dos fatos. Em nossa leitura, entendemos que essa espetacularização feita ao longo do texto está destacada nos subtítulos da reportagem, particularmente através das afirmações:

"Um livro para 12 homens sábios"

"Ninguém mais no mundo poderia entender a relatividade, disse Einstein quando seus editores a aceitaram para publicação". 
Além disso, há uma recorrência na reportagem do NYT em afirmar que a Teoria da Relatividade Geral, principal objeto em análise no contexto das observações do eclipse, não pode ser inteligível a "homens comuns".

Thomson colocou que as diferenças entre as teorias de Newton e de Einstein são infinitesimais em um sentido popular, e como elas são puramente matemáticas e podem ser expressadas apenas por termos estritamente científicos, é inútil se esforçar para detalhar essas diferenças para os homens na rua.

As descobertas, embora muito importantes, não afetaram nada, no entanto, nesta Terra. Elas não dizem respeito a seres humanos comuns; apenas astrônomos são afetados.

A reportagem coloca a teoria de Einstein em um patamar de incompreensão que até mesmo seus pares não a compreenderiam.

Quando ele submeteu seu último trabalho importante aos editores, [Einstein] advertiu [warned] que não havia mais de doze pessoas em todo o mundo que o entendessem, mas os editores assumiram o risco.

Não queremos que nossa análise incorra em anacronismos. É preciso considerar o contexto de produção deste texto, que se deu apenas três anos após a publicação do artigo fundador da relatividade geral (EINSTEIN, 1916). Uma das considerações que precisamos fazer é que a década de 1910 foi marcada por estudos acerca da Física Quântica, que além de objetos de estudos diferentes, lançava mão de um aporte formal, matemático, diferente do empreendido por Einstein na TRG. Também não era usual o uso da geometria diferencial entre os astrônomos, um dos grupos com o qual a TRG abriu interlocução. Assim, a formalização da TRG gerava dificuldades de interlocução, de compreensões entre os pares. O historiador Mattew Stanley (2003) aponta a dificuldade com o formalismo matemático da relatividade como uma das principais críticas dos cientistas ingleses com relação à TRG. Esse ineditismo com relação ao formalismo é destacado pela reportagem. 
Concepções muito diferentes que estão envolvidas nesta descoberta e a necessidade de levar em consideração a teoria de Einstein foram expressas por um membro da expedição, que apontou que ela significava, entre outras coisas, que duas linhas normalmente conhecidas como paralelas se encontram eventualmente, que um círculo não é realmente circular, que três ângulos de um triângulo não necessariamente fazem a soma total de dois ângulos retos.

Contudo, mesmo considerando que, de fato, havia dificuldades de compreensão da TRG, por parte dos próprios cientistas e, mais ainda, por parte dos não cientistas, não vemos como razoável a mistificação feita em torno da teoria de Einstein. Nossa leitura indica que há uma valorização da TRG como um conhecimento pouco compreensível, quase inacessível. Missner (1985) defende que este tipo de abordagem, particularmente feita pela mídia, ajudou a produzir a figura de Einstein como um "mito".

Com relação ao objeto de análise dos astrônomos que observaram o eclipse, a saber, o desvio da luz passando próximo a corpos massivos (particularmente o Sol, neste caso), a reportagem destaca a seguinte fala de Thomson.

"O que é facilmente compreensível", ele [Thomson] continuou, "é que Einstein previu a deflexão da luz de estrelas quando passam o Sol, e o recente eclipse forneceu uma demonstração da exatidão [correctness] da predição".

Esta fala, colocada da maneira que foi, implica uma dada visão sobre o papel do experimento na ciência. Nossa leitura indica que há uma compreensão do experimento como prova definitiva de uma teoria, como se ele fosse capaz de estabelecer definitivamente qual teoria está correta. Neste episódio em particular, podemos colocar em disputa as teorias da gravitação de Newton e a proposta por Einstein. Os cientistas esperavam três possíveis resultados: 0,83 segundo de arco, chamado posteriormente de "meio desvio", previsto por Einstein em um artigo intitulado "Sobre a Influência da Gravidade na Propagação da Luz" publicado em 1911 (EINSTEIN, 1911). 
Este é um resultado considerado "semi-clássico", pois neste artigo Einstein lançou mão de princípios da Física Moderna, principalmente o "Princípio de Equivalência", mas ainda considerava o potencial gravitacional escalar, da física clássica (PAIS, 1993); Outro resultado esperado era de 1,75 segundo de arco, chamado "desvio completo", previsto no artigo fundador da TRG intitulado "Fundamentos da Teoria da Relatividade Geral" publicado em 1916, quando Einstein passou a usar interpretações a partir de geometrias diferenciais (EINSTEIN, 1916); ou, ainda, um "desvio nulo", isto é, a luz não sofreria desvio em seu caminho. O desvio nulo e o meio desvio confirmariam a já consolidada Teoria da Gravitação Universal, proposta pelo inglês Isaac Newton. Já o desvio completo corroboraria a TRG, do alemão Albert Einstein (EINSENSTEADT \& VIDEIRA, 1995, p.30).

Contudo, acreditamos que seja necessária a problematização dos resultados obtidos com a observação do eclipse de 1919. Embora consideremos o experimento como uma prática imprescindível na atividade científica, e que ele seja usado como um dos critérios para se adotar, ou não, determinadas teorias, é preciso entender que a própria construção de aparatos experimentais, ou de metodologias de experimentação, passam por compreensões teóricas. Isto é, observação e interpretação são processos indissociáveis, como aponta Norwood Hanson (1979). Além disso, toda medida em Física, e em outras ciências, carregam desvios, incertezas. Assim, nenhuma medida é considerada "exata". Reconhecer as incertezas das medidas é fundamental para podermos concluir algo a respeito de resultados obtidos em um experimento. Frank Dyson, Arthur Eddington e David Cromellin apresentaram os resultados de suas observações com suas respectivas incertezas, o que fica omitido na reportagem. Omitiram, também, que os resultados de um dos telescópios trazidos ao Brasil indicavam um "meio desvio", resultado que corroboraria a teoria newtoniana. Os astrônomos citados acima apresentaram na reunião conjunta entre Royal Society e Royal Astronomical Society uma hipótese de que o instrumento de medida teria sofrido interferências relacionadas às 
condições climáticas, a saber, um desvio no foco do coleostato do telescópio devido ao aquecimento de seu espelho (STANLEY, 2003).

De acordo com Stanley (2003), pouco antes da reunião em 6 de novembro de 1919, Eddington mudou de ideia sobre a apresentação do elemento possivelmente mais importante: os resultados finais. Inicialmente, os resultados de todos os três telescópios foram calculados para dar uma deflexão média muito boa de 1,64. Ele decidiu que esse procedimento poderia ser enganoso, dado os problemas óbvios com um dos três conjuntos de dados. Em carta à Dyson, Eddington afirmou o seguinte:

\footnotetext{
"Eu não gosto da combinação do astrográfico com os outros resultados de Sobral - particularmente porque faz com que a média chegue tão perto da verdade. Eu não acho que isso possa ser justificado; os erros prováveis de ambos são inferiores a 0,1 , portanto são manifestamente discordantes. . . Parece arbitrário combinar um resultado que definitivamente discorda [da previsão de Einstein] com um resultado que concorde e assim obter um acordo ainda melhor [com Einstein]" (EDDINGTON apud STANLEY, 2003, p.78).
}

Assim, ficou acordado que os três conjuntos de dados seriam apresentados separadamente, de modo a esclarecer o argumento a favor e contra cada um. (STANLEY, 2003, p. 78). Nota-se que as considerações acerca das incertezas foram primordiais para tal decisão. Para Stanley (2003), embora houvesse dados consistentes que corroboravam a teoria da relatividade geral, não se pode dizer que os resultados foram precisos e indiscutíveis: "O erro foi bastante grande - e de fato não seria muito melhorado até muito mais tarde, com o desenvolvimento de técnicas como o delay de tempo de Shapiro" (STANLEY, 2003, p. 89).

Do ponto de vista das relações da TRG com aspectos sociais, além da reportagem do NYT veicular uma imagem de impossibilidade de acesso a essa teoria por parte de "homens comuns", chama-nos especial atenção a descrição feita de Einstein. 
Albert Einstein é um cidadão suíço, com cerca de 50 anos de idade. Depois de ocupar uma posição como Professor de Física Matemática na Escola Politécnica de Zurique e depois disso na Universidade de Praga, ele foi eleito membro da William's Scientific Academy em Berlim, na eclosão da guerra. Dr. Einstein protestou contra o manifesto dos professores alemães aprovando a participação da Alemanha na guerra, e nesta conclusão ele acolheu [welcomed] a revolução.

O jornal estadunidense caracteriza Albert Einstein como um cidadão suíço e destaca seu posicionamento contrário ao que ficou conhecido como "Manifesto dos 93"23. Essa caracterização indica algo extremamente importante do contexto da época, a saber, o "boicote à ciência alemã" devido à guerra. $\mathrm{O}$ armistício ocorrera cerca de um ano antes da publicação da reportagem que selecionamos do jornal NYT. Assim, desvincular a figura de Einstein da nacionalidade alemã tem algumas intencionalidades, como categorizá-lo como aliado, considerando que ele era contrário ao inimigo em comum, a Alemanha. Além disso, categorizá-lo como alemão significaria, em alguma instância, enquadrá-lo no lado "perdedor", já que a Alemanha havia assinado sua rendição. Como afirma Stanley (2003, p.83), claramente o correspondente estava preocupado em demonstrar que o criador dessa nova teoria não tinha nada a ver com os cientistas que haviam ajudado e encorajado a guerra. Um ano depois do armistício, aqueles homens britânicos de ciência que realizaram a expedição e suas medições ainda precisavam de proteção contra as acusações de que estavam consorciando com o inimigo.

Embora haja, de maneira geral, uma busca por impessoalidade no jornalismo, temos que considerar que não há possibilidade de produção neutra. A linguagem é, necessariamente, ideológica. Nesta reportagem, fica evidenciado a pessoalidade de quem produziu o texto, na seguinte afirmação:

\footnotetext{
${ }^{23}$ Título original do manifesto é "Manifesto ao mundo civilizado", no qual 93 personalidades intelectuais da Alemanha, dentre eles cientistas, manifestaram apoio a atitudes de guerra da Alemanha, no contexto do que hoje chamamos de Primeira Grande Guerra ou Primeira Guerra Mundial.
} 
Alguns cínicos sugerem que a teoria de Einstein é apenas uma versão científica do fenômeno bem conhecido de uma moeda em uma bacia de água que não está no local onde parece estar e perguntam qual é a novidade na refração da luz.

Claramente quem produziu o texto sai em defesa de Einstein e ataca, de maneira relativamente áspera, os críticos da TRG. De fato, de acordo com Stanley (2003) e Kennifick (2007) a refração da atmosfera solar era a alternativa mais popular à explicação de Einstein, embora houvessem outras.

\begin{abstract}
A objeção mais desenvolvida era que a refração na atmosfera solar poderia criar um efeito idêntico ao da deflexão gravitacional. Outras possibilidades incluíam efeitos ópticos das partículas responsáveis pela luz zodiacal e uma condensação do éter ao redor do sol, sendo que ambos poderiam produzir efeitos de deflexão (STANLEY, 2003, p. 72)
\end{abstract}

Contudo, já havia à época uma compreensão aprimorada acerca de atmosferas estelares. Segundo Stanley (2003, p.72), Lindemann, um inglês de origem alemã, respondeu às principais críticas com páginas de cálculos detalhados mostrando que a densidade da atmosfera estelar necessária para causar refração apreciável era improvável. Um dos argumentos era que havia várias boas observações de cometas passando perto o suficiente do sol para descartar a possibilidade de uma atmosfera mais densa do que se supunha. Com relação às partículas zodiacais, Lindemann afimava que eram muito rarefeitas, e enquanto uma condensação de éter duplicaria o efeito qualitativo, ninguém tinha um modelo de éter suficientemente bom para fazer uma previsão quantitativa: "Uma objeção tão vaga, Lindemann disse, deve ter pouco peso em comparação com a teoria detalhada e consistente de Einstein" (STANLEY, 2003, p. 72). 


\subsection{Análise do texto "Revolution in Science", publicado no jornal The Times London, em 7 de Novembro de 1919}

Os aspectos sociais presentes no texto do The Times London concentram-se em características relacionadas à dinâmica de funcionamento do que podemos chamar de "comunidade científica". Uma dessas características diz respeito ao interesse dos pares por um determinado acontecimento na ciência. Para os autores do texto do The Times London, a disputa entre duas teorias tidas como rivais, Teoria da Relatividade Geral e Gravitação Universal newtoniana, foi determinante para o interesse dos físicos e astrônomos da época na apresentação dos resultados das observações do Eclipse Solar Total, fenômeno que colocaria à prova as duas teorias.

O maior interesse possível havia sido despertado nos círculos científicos pela esperança de que teorias rivais sobre um problema físico fundamental fossem postas à prova, e houve um grande comparecimento de astrônomos $e$ físicos.

Algo que chama a atenção neste episódio, e que, segundo Missner (1985), tornou a teoria de Einstein famosa, é que "usualmente, teorias científicas são estabelecidas através de um acúmulo lento de dados; contudo, a teoria da relatividade foi dramaticamente confirmada por um evento" (MISSNER, 1985, p. 269). Considerando esta afirmação de Missner, podemos entender que o interesse da comunidade científica pelo evento que apresentou os resultados das observações do eclipse de 1919, além de representar o comportamento social da comunidade científica da época, tem relação com questões epistemológicas. Em outras palavras, os cientistas estavam diante de um contexto de justificação de uma teoria diferente do que se tinha usualmente. É tentador, neste sentido, colocar este episódio como um verdadeiro “experimento crucial”. O historiador Mattew Stanley afirma que Eddington "descreveu o trabalho [observações do eclipse] como um teste crucial entre as leis de Newton e Einstein e observou que os 
resultados claramente favoreciam a deflexão maior [de Einstien]" (STANLEY, 2003, p. 79). Contudo, como apontam Collins e Pinch (apud KENNIFICK, 2007, s/p) não existe um experimento definitivo que resolva todas as dúvidas e prove uma teoria sobre outra.

Embora a reunião tivesse como objetivo principal apresentar os resultados das observações do eclipse, a reportagem destaca que o interesse dos participantes concentrava-se mais na discussão acerca da relevância teórica da relatividade geral do que propriamente nos resultados das observações.

Até agora o assunto estava claro, mas quando a discussão começou ficou evidente [plain] que o interesse científico se concentrou mais na relevância [bearings] teórica dos resultados do que nos resultados em si.

Uma possível interpretação para este interesse, considerando o contexto mais amplo em que se inseriu essa reunião e a produção do texto do The Times London, é a suposta disputa entre duas teorias que, ao cabo, colocavam em disputa a teoria de um físico alemão, Albert Einstein, e a teoria de um dos maiores ícones da ciência inglesa, Isaac Newton. Para intensificar essa disputa, o cenário era a Universidade de Cambridge, "casa" de Newton. A descrição feita pelo cientista Whitehead da reunião na qual foram publicados os resultados das observações do eclipse é um bom exemplo deste clima de rivalidade entre uma teoria inglesa e outra alemã.

\footnotetext{
Toda a atmosfera de tenso interesse era exatamente igual à do drama grego: havia uma qualidade dramática na própria encenação: - o cerimonial tradicional, e no fundo a imagem de Newton para nos lembrar que a maior das generalizações científicas estava agora, depois de mais de dois séculos, para receber sua primeira modificação. (Whitehead apud STANLEY, 2003, p.78-79).
}

Considerando que disputas na ciência não estão totalmente no campo da razão, parece-nos plausível que os debates tenham se concentrado nos fundamentos teóricos daquela que poderia ser a nova teoria que interpreta 
os fenômenos gravitacionais. Parece-nos razoável considerar que essa disputa se intensificou justamente pelo contexto do pós primeira guerra. Colocar Alemanha e Inglaterra em oposição, ainda que indiretamente através de uma suposta disputa entre duas teorias físicas, pode ter acentuado o interesse dos cientistas ingleses, a partir de posturas céticas, em discutir a relevância teórica da Relatividade Geral, proposta por Einstein, um físico alemão.

A suposta disputa foi colocada em termos das observações de um fenômeno previsto por Einstein em 1911 (EINSTEIN, 1911), que fora reinterpretado no trabalho fundador da Teoria da Relatividade Geral (EINSTEIN, 1916). Tal previsão versava sobre o grau de desvio que a luz de uma estrela distante sofreria ao passar próximo a corpos supermassivos, como o Sol. A este respeito a reportagem afirma o seguinte:

O objeto desejado era verificar se a luz vinda dessas estrelas, passando pelo Sol, vem diretamente a nós como se o Sol não estivesse lá, ou se há uma deflexão devido a sua presença que poderia aparecer nas placas fotográficas como uma distância mensurável das posiçôes teóricas das estrelas.

Embora esse efeito tenha sido associado a Einstein, sendo chamado de "Efeito Einstein" ou "Lei de Einstein", alguns cientistas mostraram que tal fenômeno poderia ser previsto a partir dos princípios de Newton. Contudo, havia divergência no grau de deflexão. O desvio de 0,87 ", que foi previsto por Einstein em 1911 (EINSTEIN, 1911) ficou conhecido como "meio desvio" e estaria de acordo com os princípios da teoria newtoniana.

Uma característica marcante da teoria da Relatividade Geral, e que constava nas discussões dos cientistas da época, está relacionada ao seu formalismo matemático. A reportagem dá destaque às interpretações a partir de geometrias não euclidianas, cuja soma dos ângulos de um triângulo, por exemplo, pode ser diferente de $180^{\circ}$.

Posto de maneira mais geral pode ser descrito da seguinte forma; os princípios newtonianos pressupõem que o espaço é invariável, que, por 
exemplo, os três ângulos de um triângulo sempre são iguais e devem ser iguais a dois ângulos retos. Mas esses princípios realmente se baseiam na observação de que os ângulos de um triângulo são iguais a dois ângulos retos e que um círculo é realmente circular. Mas há certos fatos físicos que parecem lançar dúvidas sobre a universalidade dessas observações, e sugerem que o espaço pode adquirir uma curvatura [twist] ou deformação [warp] em certas circunstâncias, como, por exemplo, sob a influência da gravitação, um deslocamento ligeiro em si mesmo e aplicável aos instrumentos de medida, bem como às coisas medidas.

Mesmo em características que parecem fundamentalmente teóricas, suscitavam-se críticas dos céticos da Teoria da Relatividade Geral. O alto grau de abstração da teoria de Einstein era visto por cientistas ingleses como algo negativo. No limite, chegou-se a associar-se essa abstração, ou o formalismo de maneira geral, às atitudes violentas empreendidas pela Alemanha na primeira Guerra Mundial. Em uma carta de Rudolph Moritz a Philip Cowell, datada de $1^{\circ}$ de março de 1918, podemos ler uma associação da "bestialidade" do formalismo da geometria diferencial com acontecimentos que marcaram a sociedade inglesa durante a primeira guerra, como a invasão da cidade belga de Louvein e o ataque ao navio civil "Lusitânia".

\footnotetext{
"Eu posso acompanhar tudo [da relatividade especial] analiticamente e fisicamente e acredito que seja verdade. A segunda teoria de Einstein [relatividade geral], em 1914, é muito mais especulativa e temo que apenas concordância com observações me faça aceitá-la. Além disso, a análise é muito bestial em relação a palavras. Posso muito bem entender os compatriotas de Riemann e Christoffel queimando Louvain e afundando o Lusitânia" (Rudolph Moritz a Philip Cowell apud KENNIFICK, 2007, s/p)
}

Em outras palavras, como afirmou o historiador Kennifick (2007), "a atrocidade de inventar os mecanismos de geometria diferencial baseados no tensor, que sustentam a relatividade geral, equivale, moralmente falando, 
aos crimes de guerra mais notórios [para ingleses] da Primeira Guerra Mundial" (KENNIFICK, 2007, s/p).

A reportagem do The Times London dá destaque a interpretações que elevam a importância das observações do eclipse, e particularmente da confirmação da predição de Einstein.

Tais observações foram declaradas pelo Presidente da Royal Society como o evento científico mais proeminente desde a descoberta da existência prevista do planeta Netuno.

Contudo, nossa leitura indica que os autores da reportagem, embora claramente entusiasmados com a confirmação da relatividade geral, exercem uma característica cara ao jornalismo, a saber, a apresentação de visões divergentes sobre um mesmo acontecimento.

Mas havia uma diferença de opinião sobre a ciência estar meramente diante de um fato novo e não explicado, ou de uma teoria que revolucionaria completamente os fundamentos aceitos da física.

O historiador Mattew Stanley (2003) destaca o debate metafísico, epistemológico, acerca da seguinte questão: os resultados das observações do eclipse validam apenas a "lei de Einstein", isto é, a previsão da deflexão da luz próxima a corpos massivos, ou valida a teoria da relatividade geral como um todo?

O próprio Arthur Eddington, astrônomo inglês e um dos principais defensores da Teoria da Relatividade Geral, colocou os resultados das observações apenas em termos da confirmação da "lei de Einstein".

\footnotetext{
"Esse efeito [a deflexão da luz] pode ser tomado como prova da lei de Einstein, e não de sua teoria. Este efeito de deflexão não é afetado pela falha em detectar o deslocamento das linhas Fraunhofer no Sol. Se esta última falha for confirmada, ela não afetará a lei da gravitação de Einstein, mas afetará os pontos de vista sobre os quais a lei foi estabelecida. A lei está certa, embora as ideias fundamentais subjacentes ainda possam ser questionadas" (EDDINGTON apud STANLEY, 2003, p.79).
} 
De acordo com Stanley (2003) a afirmação de Eddington de que a "lei de Einstein", e não necessariamente sua teoria, tinha sido provada, era uma caracterização adequada da opinião entre os astrônomos. Embora ele certamente não achasse que a distinção entre a comprovação da lei de Einstein ou da teoria como um todo fosse válida (STANLEY, 2003, p.81), ela foi particularmente útil para Eddington, na medida em que permitia-lhe publicar uma confirmação de Einstein, mesmo na ausência dos resultados espectroscópicos (STANLEY, 2003, p.81).

Ainda no campo das controvérsias que os resultados trouxeram à reunião de 6 de novembro de 1919, a reportagem destaca a postura de Oliver Lodge, reconhecidamente como um dos principais críticos da teoria da relatividade geral (STANLEY, 2003, p. 69), durante a reunião. Destacam, particularmente, o fato de o eminente cientista ter deixado a reunião antes de sua conclusão.

Nesse estágio, Sir Oliver Lodge, cuja contribuição para a discussão havia sido ansiosamente esperada, saiu da reunião.

Nossa leitura dessa passagem indica que, embora de um ponto de vista normativo não devêssemos aceitar que posturas pessoais influenciem o debate científico, na prática é difícil dissociar as discordâncias de visão de mundo e posturas individuais. Em um ambiente cuja aceitação da teoria de Einstein parecia ser a postura mais recorrente, a saída de um de seus críticos no meio da reunião passa a ser destacada.

Por fim, a reportagem é concluída colocando em aberto o debate sobre a validade da teoria da Relatividade Geral.

Suas previsões em dois dos três casos foram verificadas agora, mas a questão permanece em aberto sobre se as verificações provam a teoria da qual as previsões foram deduzidas.

Embora achemos louvável que a reportagem não coloque os resultados das observações do Eclipse de 1919 como uma prova definitiva da teoria de Einstein, temos que destacar que nossa leitura indica uma postura 
contraditória dos autores do texto do The Times London, sobretudo se considerarmos o título do texto "Revolução na Ciência: Ideias Newtonianas caídas”. Essa prática não é incomum, na qual a manchete da reportagem parece não guardar coerência com o que é apresentado no texto. Foi o que aconteceu, na nossa interpretação, neste texto analisado.

\subsection{Análise do texto "Time, Space and Gravitation: The Newtonian System", escrita por Einstein ao Jornal The Times London, em 28 de Novembro de 1919}

A convite da redação do jornal The Times London, o próprio Einstein, figura central nas discussões acerca dos resultados das observações do Eclipse de 1919 através de sua teoria da relatividade geral, escreve um texto publicado neste jornal de grande circulação na Inglaterra. Como seria de se esperar, o convite foi feito com a expectativa de que o físico que propôs a relatividade pudesse destacar os pontos fundamentais de sua teoria. De fato, a leitura do texto de Einstein indica claramente uma tentativa, quase exaustiva, de apresentar a teoria da relatividade. Como veremos adiante, Einstein buscou apresentar uma visão holística de sua teoria, incluindo a relatividade restrita e geral, em vez de ater-se apenas ao efeito de curvatura da luz que estava em destaque pelas observações do eclipse.

Contudo, o que mais chama a atenção no texto de Einstein, na nossa leitura, é a percepção do significado e das implicações sociais das observações de sua predição terem sido empreendidas por equipes inglesas. O físico alemão começa seu texto, justamente, agradecendo a possibilidade de interlocução com os ingleses.

Depois da lamentável ruptura nas antigas [former] relações internacionais existentes entre os homens da ciência, é com alegria $e$ gratidão que aceito esta oportunidade de comunicação com astrônomos $e$ físicos ingleses. 
À primeira leitura pode parecer apenas um gesto de cordialidade por parte de Einstein. Contudo, à guisa do contexto da primeira guerra podemos concluir que essa consideração feita por Einstein é extremamente relevante. $\mathrm{O}$ virulento sentimento anti-alemão encontrado em toda a Grã-Bretanha, França e América começara a ter consequências concretas para a possibilidade de restabelecer as relações científicas depois da guerra (STANLEY, 2003, p.70). Havia, concretamente, um clima de hostilidade de ambas as partes, de modo que a cooperação internacional da ciência estava seriamente comprometida. Neste período ocorreu o que ficou conhecido como "boicote à ciência alemã". Vários periódicos ingleses passaram a publicar críticas contundentes à ciência alemã e aos cientistas alemães. Por exemplo, em uma publicação do "Oxford note-books" a aceitação de cientistas alemães na comunidade internacional era tida como um rebaixamento das leis internacionais: "O dilema é inexorável: podemos readmitir a Alemanha à sociedade internacional e baixar nosso padrão de leis internacionais a seu nível, ou podemos excluí-la e aumentar o padrão das leis internacionais. Não há terceiro curso" (Oxford note-book apud STANLEY, 2003, p. 63). De acordo com Stanley (2003), um dos principais cientistas ingleses que chefiava as publicações anti-germânicas no "Oxford note-book" era Turner. A postura germanofóbica de Turner era representativa, de acordo com Stanley (2003), da maior parte da população britânica.

\footnotetext{
Turner - e a maior parte da população britânica - recusou-se a acreditar que indivíduos alemães, cientistas ou não, pudessem afirmar com sinceridade que não participavam das atrocidades de seu governo. (STANLEY, 2003, p. 66).
}

Claro que havia uma minoria contrária às hostilidades aos alemães. Dentre eles, encontra-se o astrônomo e Quaker Arthur Eddington, figura central na organização das expedições para observar o eclipse de maio de 1919. As expedições inglesas que buscavam observar o efeito de curvatura da luz, previsto por Einstein, foi exatamente o tipo de trabalho que exigia a cooperação internacional que Eddington argumentara ser fundamental para o espírito da ciência. Além disso, Stanley afirma que essas expedições 
"ofereciam uma oportunidade de trazer notoriedade, tanto para a ciência quanto para a sociedade, a um amante da paz e perspicaz alemão" (STANLEY, 2003, p.71). Isto é, além do interesse pela teoria da relatividade geral, Eddington via a possibilidade de dar destaque a um cientista alinhado, assim como ele próprio, ao pacifismo. A postura de Einstein ao longo do texto publicado no The Times London, particularmente no início, mostra a valorização que Einstein dava às relações pacíficas na ciência.

Einstein estende sua introdução ainda falando sobre o contexto sociológico envolvido neste episódio.

Foi de acordo com a alta e altiva [pround] tradição da ciência inglesa que os cientistas ingleses deviam ter dado seu tempo e trabalho e que as instituições inglesas deveriam ter fornecido os meios materiais para testar uma teoria que havia sido completada e publicada no país de seus inimigos no meio da guerra.

Embora a investigação da influência do campo gravitacional solar sobre os raios de luz seja uma questão puramente objetiva, não deixo de estar muito contente [glad] em expressar meus agradecimentos pessoais aos meus colegas ingleses neste ramo da ciência; pois sem a ajuda deles eu não teria obtido a prova da dedução mais vital da minha teoria.

Destacamos nessas passagens, além da valorização do reestabelecimento da cooperação internacional na ciência, a valorização que Einstein dá ao apoio material dado pelas instituições inglesas. Isto torna a cooperação ainda mais significativa, pois não se tratou apenas de iniciativas individuais, como as de Eddington. Expedições como as que foram empreendidas custam caro, e sem o apoio institucional seria inviável de ser executada. Neste sentido, Frank Dyson, como astrônomo real e importante membro da Royal Astronomical Society, foi fundamental para o apoio institucional, particularmente para o apoio financeiro.

O dinheiro era um problema imediato, e Dyson planejava se candidatar a um subsídio do governo que incluiria 100 libras 
esterlinas para a modificação de instrumentos e 1.000 libras contingenciando a viabilidade das expedições (STANLEY, 2003, p.73).

Claro que o apoio institucional não se limita ao apoio financeiro. Podemos elencar como fundamental o apoio dado pelo observatório de Greenwich e de Cambridge ao disponibilizarem os materiais experimentais, tais como telescópios, chapas fotográficas, etc.

Outro aspecto que nos chama a atenção é que Einstein qualifica as observações como fundamentais, visto que o ajudou a provar a "dedução mais vital" de sua teoria. E, de acordo com Einstein, embora a observação de sua previsão teórica tratasse apenas de uma questão objetiva, não teria sido possível sem o apoio dos ingleses.

Einstein é reconhecidamente um cientista que despendia energia tentando interpretar sua própria produção. Em outras palavras, a produção filosófica e epistemológica é uma marca do trabalho do físico alemão, considerado como um "cientista-filósofo" (PATY, 1993). Esta característica se fez presente no texto publicado no The Times London. Einstein introduz sua teoria a partir de uma discussão epistemológica, particularmente sobre tipos de teorias, que chamou de "teorias construtivas" e "teorias de princípios".

Existem vários tipos de teorias na física. A maioria delas é construtiva. Estas tentam construir uma imagem de fenômenos complexos a partir de alguma proposição relativamente simples.

Quando dizemos que entendemos um grupo de fenômenos naturais, queremos dizer que encontramos uma teoria construtiva que abrangem esses fenômenos.

Além de teorias construtivas, Einstein propõe a existência de teorias de princípios, categoria na qual enquadrou a Teoria da Relatividade.

Teorias de princípio empregam o método analítico, não o sintético. Seu ponto de partida e fundamento não são constituintes hipotéticos, mas 
propriedades gerais de fenômenos observados empiricamente, princípios dos quais são deduzidas fórmulas matemáticas de tal tipo que se aplicam a todos os casos que se apresentam.

Para ele o mérito das teorias de princípio, por consequência da teoria da relatividade, é sua perfeição lógica e segurança em seus fundamentos. Einstein frequentemente comparava a Teoria da Relatividade com a Termodinâmica, tida por ele como um "exemplar" das teorias de princípios (STACHEL, 2002a, p. 225).

A partir dessa discussão epistemológica, Einstein afirma no texto do The Times London que para compreender sua teoria é imprescindível que se compreenda os princípios sob os quais ela foi desenvolvida. Passa, então, de uma abordagem filosófica a uma abordagem conceitual e histórica, uma vez que apresenta alguns dos caminhos da construção da teoria da relatividade, desde a especial até a geral.

Mas, antes de afirmar isso, é necessário salientar que a teoria da relatividade é como uma casa com duas histórias separadas, a teoria da relatividade especial e a teoria da relatividade geral.

Para apresentar sua teoria, Einstein toma uma postura didática e começa por introduzir a ideia de movimento e de sistema de referência, fundamental para a compreensão de sua teoria, ou de qualquer outra teoria que envolva cinemática.

Desde a época dos antigos gregos, é bem conhecido que, ao descrever o movimento de um corpo, devemos nos referir a outro corpo. O movimento de um trem é descrito com referência ao solo, o de um planeta com referência ao conjunto total de estrelas fixas visíveis. Na física, os corpos aos quais os movimentos são espacialmente referenciados são denominados sistemas de coordenadas. As leis da mecânica de Galileu e Newton podem ser formuladas apenas usando um sistema de coordenadas. 
Seguindo com sua abordagem didática, Einstein chama a atenção de que nem todos os referenciais são igualmente válidos na física clássica e na relatividade especial.

$O$ estado de movimento de um sistema de coordenadas não pode ser escolhido arbitrariamente se as leis da mecânica forem válidas (deve estar livre de rotações e de aceleração). O sistema de coordenadas empregado na mecânica é chamado de sistema inercial.

Einstein descreve um sistema de coordenadas inercial da seguinte maneira: um sistema de coordenadas movendo-se na mesma direção e com a mesma velocidade que um sistema inercial é ele próprio um sistema inercial.

Percebe-se que Einstein caracteriza um sistema inercial a partir de outro sistema inercial. Isto é, são considerados inerciais aqueles sistemas de coordenadas que não têm acelerações relativas entre si. Esta abordagem mostra, em nossa leitura, que a ideia de sistema inercial passa, necessariamente, por elencar um sistema privilegiado. Em outras palavras, o sistema inercial é um sistema de coordenadas movendo-se na mesma direção e sem aceleração com relação a outro sistema inercial (privilegiado).

Tendo apresentado minimamente a ideia de sistemas de referência, Einstein passa a apresentar os princípios da relatividade especial, começando pelo "Princípio de Relatividade":

A teoria da relatividade especial é, portanto, a aplicação da seguinte proposição a qualquer processo natural: "Todas as leis da natureza que sejam válidas em relação a um sistema de coordenadas $K$ também devem ser válidas para qualquer outro sistema $K^{\prime}$, desde que $K$ e $K$ ' estejam em movimento de translação uniforme”.

Em seguida apresenta o princípio de constância da velocidade da luz.

O segundo princípio sobre o qual repousa a teoria da relatividade especial é o da constância da velocidade da luz no vácuo. A luz no vácuo tem uma velocidade definida e constante, independente da velocidade da sua fonte. Os 
físicos devem sua confiança nesta proposição à teoria da eletrodinâmica de Maxwell-Lorentz.

Afirma que esses princípios, aparentemente contraditórios entre si, foram estabelecidos a partir da proposição de uma nova cinemática.

Os dois princípios que mencionei receberam forte confirmação experimental, mas não parecem ser logicamente compatíveis. A teoria da relatividade especial alcançou sua reconciliação lógica fazendo uma mudança na cinemática, isto é, na doutrina [doctrine] das leis físicas do espaço e do tempo. Tornou-se evidente que uma declaração da coincidência [coincidence] de dois eventos poderia ter um significado apenas em relação a um sistema de coordenadas, que a massa dos corpos e a taxa de movimento dos relógios devem depender do seu estado de movimento em relação às coordenadas.

Jurgen Renn (2007, p.31) aponta que a teoria da relatividade especial surge na interface teórica entre mecânica e eletromagnetismo. Em suas notas autobiográficas, Einstein apresenta um experimento de pensamento importante na construção de sua teoria, a saber, a perseguição de um raio de luz à velocidade da luz. O que seria observado nesta situação imaginária?

\begin{abstract}
Após dez anos de estudo, o princípio [de relatividade] surgiu, resultando de um paradoxo com o qual me defrontara quando tinha dezesseis anos: se um raio luminoso for perseguido a uma velocidade c (velocidade da luz no vácuo), observamos esse raio de luz como um campo eletromagnético em repouso, embora com oscilação espacial. Entretanto, aparentemente não existe tal coisa, quer com base na experiência, quer de acordo com as equações de Maxwell. Desde o início, tive a intuição clara de que, segundo o ponto de vista desse observador, tudo devia acontecer de acordo com as mesmas leis aplicáveis a um observador que estivesse em repouso em relação à terra. Pois, como poderia o primeiro observador saber ou determinar que está em estado de movimento rápido uniforme? (EINSTEIN, 1982, p.55)
\end{abstract}

A certa altura, Einstein ficou convencido de que não seria possível superar este paradoxo considerando simplesmente o que havia sido 
desenvolvido até então. Surgia, assim, a necessidade de mudanças radicais, no sentido de discutir sobre as raízes do conhecimento físico, sobre seus fundamentos. Havia a necessidade do surgimento de uma nova teoria, pois os esforços construtivos para conciliar o eletromagnetismo e a mecânica não poderiam ser "frutíferos".

\footnotetext{
Esse tipo de raciocínio levou-me a concluir [...] que nem a mecânica e nem a eletrodinâmica podiam (exceto nos casos limites) reivindicar validade exata. Gradualmente perdi a esperança de descobrir as leis verdadeiras através dos esforços construtivos, baseado em fatos conhecidos. Quanto mais me dedicava a esse objetivo, mais me convencia de que só a descoberta de um princípio formal universal poderia levar a resultados seguros e positivos. (EINSTEIN, 1982, p.54)
}

O paradoxo que apresentamos anteriormente foi, de acordo com Einstein, fundamental para a descoberta deste princípio formal universal: [...] Vemos nesse paradoxo o germe da teoria da relatividade restrita" (EINSTEIN, 1982, p.55). Este paradoxo configura-se, sobretudo, como uma aparente incompatibilidade entre a lei da constância da velocidade da luz e o princípio de relatividade, como apontado por Einstein em seu texto no The Times London. A superação dessa incompatibilidade dependia particularmente da superação da crença no caráter absoluto de tempo e espaço.

A física teve que ser modificada. A mudança mais notável foi uma nova lei do movimento para pontos de massa em movimento muito rápidos, e isso logo veio a ser verificado no caso de partículas eletricamente carregadas.

Essa nova cinemática, baseada nas "transformações de Lorentz", foi apresentada no artigo "Sobre a Eletrodinâmica dos corpos em movimento", publicado em 1905. Pelo próprio título do artigo, podemos notar que Einstein enquadrava seu trabalho dentro da perspectiva teórica do eletromagnetismo. Ele aponta essa consideração no texto publicado no Times London. 
A teoria da relatividade especial, que era simplesmente uma extensão sistemática da eletrodinâmica de Maxwell e Lorentz, teve conseqüências que ultrapassaram a si mesma.

Em seu texto ao The Times London, Einstein apresenta como principal desdobramento da relatividade especial a relação do conteúdo energético de um sistema à sua massa inerte, também conhecido como equivalência entre massa e energia, representada por uma das equações mais famosas da Física: $\mathrm{E}=\mathrm{mc}^{2}$.

O resultado mais importante do sistema da relatividade especial dizia respeito à massa inerte de um sistema material. Ficou evidente que a inércia de tal sistema deve depender de seu conteúdo energético, de modo que fomos levados à concepção de que a massa inerte não era nada mais que energia latente. A doutrina da conservação da massa perdeu sua independência e se fundiu na doutrina da conservação da energia.

Contudo, em uma perspectiva histórica, Einstein afirma em seu texto para o The Times London que a abordagem da teoria da relatividade especial era limitada, particularmente porque circunscrevia sua validade à sistemas de referências inerciais.

A independência das leis físicas em relação a um sistema de coordenadas deve ser limitada a sistemas de coordenadas em movimento uniforme de translação em relação a um outro? $O$ que tem a natureza a ver com os sistemas de coordenadas que propomos e com os seus movimentos?

Embora seja necessário que nossas descrições da natureza empreguem sistemas de coordenadas que selecionamos arbitrariamente, a escolha não deve ser limitada de modo algum no que diz respeito ao seu estado de movimento.

Havia um incômodo, a nível de fundamentos, com a escolha dos referenciais. Einstein achava que os sistemas de coordenadas deveriam ser arbitrários, sem que houvesse qualquer tipo de predileção por um sistema ou outro. Em outras palavras, a realidade física não pode ser ditada pela 
escolha de um sistema de coordenadas matemático. Portanto, para Einstein o princípio de relatividade deveria ser válido para qualquer sistema de referência. Assim, o caminho histórico de sua teoria foi a busca pela generalização do princípio de relatividade. Contudo, esta busca gerou alguns conflitos. O primeiro deles, que Einstein apontou em seu texto para o The Times London, dizia respeito à conhecida equivalência entre massas inerciais e gravitacionais.

Verificou-se que a aplicação desta teoria geral da relatividade estava em conflito com uma experiência bem conhecida, segundo a qual parecia que o peso e a inércia de um corpo dependiam das mesmas constantes (identidade de massas inerciais e gravitacionais).

Um dos experimentos mentais que marcou o início da formulação do princípio de equivalência da relatividade geral, um dos pilares da teoria de Einstein, foi a de um corpo em queda livre. Einstein percebeu que um corpo em queda livre não sente o próprio peso. Portanto, o observador em queda livre poderia afirmar que, localmente, seu referencial é inercial. Mas, no texto ao times London, Einstein apresenta outro experimento mental, também fundamental no desenvolvimento de sua teoria, considerado pelo historiador da ciência, John Stachel (2002 b), como o "elo perdido da relatividade geral". Trata-se do experimento mental de um referencial em rotação.

Considere o caso de um sistema de coordenadas que é concebido como estando em rotação estável em relação a um sistema inercial no sentido newtoniano. As forças que, relativamente a este sistema, são centrífugas, devem, no sentido newtoniano, ser atribuídas à inércia. Mas essas forças centrífugas são, como a gravitação, proporcionais à massa dos corpos. Não é possível, então, considerar o sistema de coordenadas como em repouso e as forças centrífugas como gravitacionais? A interpretação parecia óbvia, mas a mecânica clássica proibia isso.

Este experimento mental mostra que não é possível ao observador no sistema em rotação diferenciar se seu movimento (ser "jogado" para fora) é 
um efeito inercial ou gravitacional. Daí a equivalência entre um sistema inercial com a presença de um campo gravitacional e um sistema não inercial, rodando. Este experimento mental mostra que a generalização da teoria da relatividade deveria, necessariamente, incluir a gravitação. Einstein enfatiza isto no texto ao Times London.

Esse pequeno esboço indica como uma teoria da relatividade generalizada deve incluir as leis da gravitação, e a busca real da concepção justificou a esperança.

Abraham Pais (1993, p.226) levanta a seguinte questão a este respeito: "Terá Einstein sido conduzido inicialmente à gravitação porque queria incluí-la na relatividade restrita ou porque viu que poderia generalizar a relatividade restrita através dela?' A resposta de Pais (idem) é que "procurando a inclusão imediatamente, ou quase imediatamente, [Einstein] chegou à generalização".

Contudo, a inserção da gravitação e de referenciais não inerciais gerou um problema imediato com o formalismo matemático usado na relatividade especial, particularmente com a geometria euclidiana.

Mas o caminho era mais dificil do que se esperava, porque contradizia a geometria euclidiana.Em outras palavras, as leis segundo as quais os corpos materiais são arranjados no espaço não concordam exatamente com as leis do espaço prescritas pela geometria euclidiana dos sólidos. É isso que significa a frase "uma deformação [warp] no espaço". Os conceitos fundamentais "reta", "plano", etc, consequentemente, perdem seu significado exato na física.

Jürgen Renn (2007, p.59-60) e John Stachel (2002 a, p.261) referem-se ao desenvolvimento da TRG como um "drama em três atos".

ATO I (1907): A formulação do Princípio de Equivalência; 
ATO II (1912): Representação matemática do campo gravitacional por um tensor simétrico de segunda ordem, que entra no elemento de linha (dS) de um espaço-tempo quadri-dimensional;

ATO III (1915): Formulação das equações de campo, agora padrão (nowstandard), para o campo métrico, e o uso de sua solução esfericamente simétrica para explicar a precessão anômala do periélio de Mercúrio.

Portanto, a inserção da gravitação (Ato I) se mostrou, ao longo da construção da relatividade geral, a necessidade de um novo formalismo, a geometria diferencial tensorial (Ato II), o que gerou novas equações de campo (Ato III) que permitia, dentre outras coisas, prever o movimento de planetas e a distorção do espaço-tempo, que implicava na propagação da luz.

Na teoria da relatividade generalizada, a doutrina do espaço e do tempo, a cinemática, não é mais um dos fundamentos absolutos da física geral. Os estados geométricos dos corpos e as taxas dos relógios dependem, em primeiro lugar, de seus campos gravitacionais, que são novamente produzidos pelos sistemas materiais envolvidos.

Então, do ponto de vista dos fundamentos da teoria da relatividade, de seu formalismo, do tratamento geométrico dado à gravitação, vemos que Einstein elabora uma teoria completamente diferente da gravitação universal de Newton, estabelecida, sobretudo, a partir da ideia de forças centrais agindo instantaneamente à distância. Contudo, do ponto de vista prático, as diferenças são sutis, como afirma Einstein:

Assim, a nova teoria da gravitação diverge amplamente da de Newton em relação ao seu princípio básico. Mas na aplicação prática os dois concordam tanto que tem sido difícil encontrar casos em que as diferenças reais possam ser sujeitas a observação.

Do ponto de vista prático, isto é, de previsões teóricas divergentes entre as teorias de Newton e Einstein e que poderiam ser verificadas por meio de observações, Einstein elenca as seguintes: 
1: A distorção das órbitas elípticas dos planetas ao redor do sol (confirmada no caso do planeta Mercúrio).

2: O desvio dos raios de luz em um campo gravitacional (confirmado pela expedição inglesa do Eclipse Solar).

3. O deslocamento de linhas espectrais em direção à extremidade vermelha do espectro, no caso de luz vinda de estrelas de massa apreciável (ainda não confirmadas).

Ao colocar as diferenças entre sua teoria e a de Newton como sendo pequenas, do ponto de vista prático, Einstein, em nossa leitura, procura valorizar a obra do físico inglês, rechaçando a interpretação de que sua teoria teria sido proposta com a pretensão de substituir/desqualificar a teoria newtoniana.

Ninguém deve pensar que a grande criação de Newton pode ser derrubada em qualquer sentido real por essa ou por qualquer outra teoria. Suas ideias claras e amplas sempre manterão seu significado como a base sobre a qual nossas concepções modernas de física foram construídas.

A interpretação de Einstein, portanto, é a de que a construção da física não se dá através de grandes rupturas com teorias precedentes, mas de reinterpretações da natureza que, em alguma medida, são influenciadas pelas visões de mundo que antecedem essas interpretações.

Por fim, Einstein retoma a questão sociológica que envolve sua teoria, representando a Alemanha, e as expedições inglesas. Em um tom irônico, brinca com as representações feitas dele na mídia, em particular no próprio The Times London.

Um comentário final. A descrição de mim e de minhas circunstâncias no The Times mostra uma divertida proeza de imaginação por parte do escritor. Por uma aplicação da teoria da relatividade ao gosto dos leitores, hoje na Alemanha sou chamado de homem de ciência alemão, e na Inglaterra sou representado como um judeu suíço. Se eu chegar a ser considerado um bete 
noire, as descrições serão invertidas, e eu me tornarei um judeu suíço para os alemães e um homem de ciência alemão para os ingleses!

\subsection{Síntese}

Os textos históricos publicados na mídia do início do século XX foram selecionados e analisados em busca de aproximarmos algumas perspectivas da educação para as mídias e a história da ciência em aulas de Física, no contexto da formação inicial de Professores. A temática, observações do eclipse de 1919 e a relatividade geral, se deu, principalmente, pela proximidade com o centenário do evento, o que resultaria, em nossa hipótese à época, em grande repercussão na mídia atual. De fato, principalmente por parte das observações terem sido em Sobral, no nordeste brasileiro, vários meios de comunicação publicaram materiais sobre Einstein, o eclipse e a relatividade geral.

O intuito geral de nossa abordagem foi analisar tanto aspectos relacionados às produções midiáticas selecionadas, quanto ao contexto histórico e científico no qual as observações do eclipse estiveram envolvidas. Em outras palavras, buscamos problematizar tanto as produções midiáticas quanto o próprio tema científico ao qual elas se referiam.

Um dos exercícios críticos fundamentais para compreender a produção midiática é a confrontação entre diferentes materiais acerca de uma mesma temática. A análise que fizemos indica que os três textos abordaram, de maneira mais ou menos enfática, as tensões envolvidas nas nacionalidades dos cientistas envolvidos: astrônomos ingleses testando a teoria de um físico alemão. Tanto o NYT quanto o The Times London buscam caracterizar Einstein como um judeu Suíço. A abordagem de Einstein à sua própria nacionalidade é um contraponto às outras duas reportagens. Conscientemente, Einstein usa de ironia para dizer que se estivesse equivocado, os ingleses o caracterizariam como alemão, enquanto os alemães o caracterizariam como um judeu suíço. A problematização 
dessas relações entre nacionalidades no contexto do pós primeira guerra é fundamental para compreender o episódio das expedições do eclipse solar total de maneira mais profunda.

Além disso, a confrontação entre os materiais indica que ambos os textos do The Times apresentam contrapontos para que os resultados das observações não sejam interpretados como uma prova definitiva da teoria da relatividade geral e uma substituição completa da gravitação newtoniana. Contudo, apenas o texto de Einstein deixa isso claro. No texto "Revolution in Science" a relativização dos resultados das observações fica ofuscada pelo título da reportagem, que coloca o episódio como uma "Revolução na Ciência”. Já o NYT não apresenta moderações, vendendo a teoria da relatividade geral como a nova e única versão sobre o universo. Versão, no entanto, que só é acessível a poucos homens sábios da ciência e que não tem implicações aos homens comuns.

Para compreendermos e analisarmos textos midiáticos publicados em diferentes épocas é fundamental que esses materiais sejam confrontados com estudos de historiadores que remontem o contexto no qual foram produzidos. Julgamos que essa aproximação entre a análise de produções midiáticas e a história da ciência é profícuo na busca de posicionamentos críticos tanto para a mídia quanto para a própria ciência. 


\section{Capítulo 5}

\section{Em busca de parâmetros para a}

\section{problematização da mídia na}

educação científica

Neste capítulo buscaremos construir alguns parâmetros que entendemos fundamentais para a problematização da mídia sobre Ciência em aulas de Física. Essa construção se pretende fundamentada nas concepções freireanas apresentadas no capítulo 2 e nas discussões presentes na literatura de educação para as mídias apresentadas no capítulo 3. Além disso, a construção deste capítulo, mais do que os outros, tem forte influência da atuação prática na formação de Professores. Alguns posicionamentos antecipam pontos que serão explorados nos próximos capítulos, quando analisaremos as atividades desenvolvidas no Instituto Federal de São Paulo (IFSP).

Para começar a delinear esses parâmetros, apresentaremos duas grandes frentes para que seja possível o projeto de problematizar a mídia sobre ciência. Assim como Ribeiro e Kawamura (2008), entendemos que é fundamental na aproximação entre materiais de divulgação científica, e de mídia mais especificamente, e o ensino de ciências, a busca por criticidade em duas dimensões interconectadas:

1. Olhar crítico para a produção da mídia;

2. Olhar crítico para a produção da ciência;

Além disso, defendemos que as abordagens em sala de aula, que buscarem aproximações entre mídia e ciência, devem fazê-lo em uma perspectiva dialógica, como discutido no capítulo 2 desta tese. Entendemos que uma abordagem dialógica passa por problematizar os materiais de 
mídia em sala de aula, sobretudo problematizando-os nos dois níveis indicados acima. A abordagem dialógica e problematizadora deve priorizar a confrontação de diferentes materiais que versem sobre a mesma temática e, fundamentalmente, deve garantir a participação criativa dos estudantes envolvidos nas atividades desenvolvidas. Isto é, problematizar a mídia passa tanto pelo desenvolvimento da crítica quanto da criatividade, pois a denúncia sem o anúncio é insuficiente.

\subsection{Olhar crítico para a produção da mídia}

O olhar crítico para a produção da mídia engloba questões gerais como o interesse econômico dos grupos detentores dos principais meios de comunicação, os usos da linguagem que se faz ao projetar o público leitor, os recursos metafóricos, simplificações, etc.

Como temos insistido nos capítulos anteriores, uma das questões principais com relação à mídia é compreender que sua produção não é neutra e que, portanto, as mensagens que circulam na mídia são políticas e estão, em última instância, atreladas ao poder.

Outra questão central do debate sobre a mídia tem sido os impactos das chamadas Fake News, sobretudo em questões políticas. Na ciência esse debate também tem se aprofundado. As "Fake News na Ciência" foram tema e título do primeiro evento do ciclo ILP-FAPESP de ciência e inovação de 2019, resultado de parceria entre o Instituto Legislativo Paulista (ILP) e a Fundação de Amparo à Pesquisa do Estado de São Paulo (FAPESP).

José Tadeu Arantes, em texto de apresentação do evento no site da Agência FAPESP24, afirma que "a má informação, a desinformação e a informação falsificada assolam o mundo contemporâneo" e que "o território da ciência, supostamente protegido pelo apuro na realização das pesquisas e pelo rigor em sua difusão, não está imune". Para Arantes "as fake news

\footnotetext{
${ }^{24}$ Disponível em: http://agencia.fapesp.br/fake-news-na-ciencia/30120/. Último acesso em 07/06/2019 às $11 \mathrm{~h} 43$.
} 
invadiram o noticiário científico em uma época em que hipóteses como a do movimento geocêntrico dos planetas ou a da criação de espécies biológicas imutáveis, refutadas por séculos de estudos criteriosos e bem fundamentados, voltaram a circular na web com sabor de novidade". Como procuramos defender no capítulo anterior, acreditamos ser necessário superar o dualismo entre falso e verdadeiro. Essa superação passa pela problematização dos materiais de mídia, da confrontação com diversos materiais e com o contraste com fontes primárias usadas como embasamento dessas produções.

Neste sentido, uma característica fundamental do jornalismo, e que devemos analisar na busca por um posicionamento crítico diante desses materiais, é o que Mônica Teixeira chamou de um dos "mandamentos" do bom jornalismo: o uso do contraditório. A abertura para diferentes olhares para um fato abordado é fundamental para que se construa uma visão mais complexificada a respeito dele. Além disso, evidencia que as diversas produções não são neutras, mas partem de dadas visões de mundo.

A partir da literatura e, sobretudo a partir de nossa experiência com os Professores em formação, pudemos perceber que os temas sobre ciência são abordados na mídia, recorrentemente, de maneira homogênea. Por vezes, nossos alunos chamavam a atenção de matérias que eram copiadas ipsis literis entre canais de comunicação diferentes. Isto é, não só não há espaço para contraditório em matérias específicas sobre ciência, como apontou Teixeira (2002), mas percebemos que há pouco espaço para contraditório entre os meios de comunicação quando o assunto é ciência. Essa característica, que nos foi chamado atenção pelos próprios Professores em formação, levou-nos à leitura do sociólogo francês Pierre Bourdieu, em particular a leitura de seu livro intitulado "Sobre a Televisão".

No livro "Sobre a Televisão", Bourdieu (1997) aponta para a clara pressão econômica que os meios de comunicação sofrem na produção de seus materiais. Contudo, esta pressão vai além de saber sobre as pessoas que possuem esses meios, os anunciantes que pagam por publicidades e o Estado 
que dá subvenções. Embora considere importante discutir sobre estes pontos, o sociólogo francês considera que apenas com eles não podemos entender os "mecanismos anônimos, invisíveis, através dos quais se exercem as censuras de toda ordem que fazem da televisão um formidável instrumento de manutenção de ordem simbólica” (BOURDIEU, 1997, p. 20).

Em sua análise, Bourdieu (1997) considera que além das pressões externas, sobretudo econômicas e concretizadas pela perseguição incansável dos índices de audiência, tem-se pressões internas ao campo jornalístico, como a necessidade de reconhecimento de jornalistas por seus pares, a busca incessante pelo "furo" de reportagem e submissão ao tempo, sempre exíguo, de realização das tarefas, características que fazem com que ocorra um esvaziamento político do que é veiculado, e a consequente despolitização dos consumidores de informações.

Bourdieu entende o jornalismo como um "campo". Os jornalistas, atuando nele, "têm 'óculos' especiais a partir dos quais veem certas coisas e não outras; e veem de certa maneira as coisas que veem. Eles operam uma seleção e uma construção do que é selecionado" (BOURDIEU, 1997, p.25). Para Bourdieu, "o princípio de seleção é a busca do sensacional, do espetacular" (idem).

Importante salientar que Bourdieu defende que o jornalista "é entidade abstrata que não existe" (BOURDIEU, 1997, p. 30). Para ele, o que existe são jornalistas diferentes "segundo sexo, a idade, o nível de instrução, o jornal, o meio de informação" (idem). Ainda assim, mesmo considerando a pluralidade dos jornalistas, o autor entende que as produções jornalísticas são muito mais homogêneas do que se acredita. Tal homogeneidade está relacionada "às restrições impostas pelas fontes e por toda uma série de mecanismos, dos quais o mais importante é a lógica da concorrência" (BOURDIEU, 1997, p. 31, grifo nosso). Por exemplo, se a "Folha de São Paulo" publica uma dada manchete em sua capa, o "ESTADÃO” e outros jornais, geralmente, também se pronunciarão sobre o conteúdo abordado. Isto se deve ao fato de a produção jornalística ser coletiva. Não apenas a 
coletividade de uma redação específica, mas do conjunto dos jornalistas (BOURDIEU, 1996, p. 31).

Bourdieu afirma que "para saber o que se vai dizer é preciso saber o que os outros disseram. Esse é um dos mecanismos pelos quais se gera a homogeneidade dos produtos propostos" (BOURDIEU, 1996, p. 32). Ele caracteriza este mecanismo de homogeneização com o conceito de circulação circular da informação. Bourdieu afirma que os jornalistas, que se lêem uns aos outros, têm origens sociais semelhantes, visões de mundo parecidas e buscam atender a expectativas de um (suposto) determinado público. O resultado disso é a produção de informações e abordagens homogêneas, o que implica que os instrumentos de comunicação são pouco autônomos, limitados pelas "relações sociais entre os jornalistas, relações de concorrência encarniçada [...], que são também relações de conivência, de cumplicidade objetiva" (BOURDIEU, 1996, p.51).

Além dessa característica apontada por Bourdieu, de que os jornalistas se leem uns aos outros em suas tarefas de produção, o que geraria uma homogeneização dos conteúdos produzidos, temos hoje uma série de "agências de notícias" que tendem a pautar os conteúdos a serem abordados, o que pode ser visto como a restrição das fontes a que se referiu Bourdieu. Na ciência, em particular, temos algumas iniciativas vinculadas, inclusive, a grandes e prestigiados periódicos científicos. Sabine Righetti (2018) chama a atenção para a plataforma "EurekAlert", criada pela Associação Americana para o Avanço da Ciência. Periódicos científicos estrangeiros como a Science, a PNAS, o The Lancet e a PLOS ONE fazem parte da EurekAlert, que reúne conteúdo científico inédito de alto impacto para profissionais cadastrados. A plataforma traz, com embargo de aproximadamente uma semana, artigos científicos, press release em várias línguas, incluindo o português, animações explicativas e o telefone celular e e-mail do autor principal do estudo, que fica de sobreaviso sobre a necessidade de atender a imprensa mundial em um determinado período. Righetti chama a atenção de que "jornalistas do mundo inteiro, incluindo do Brasil, acessam diariamente a EurekAlert como parte de sua rotina diária 
de trabalho, conseguem o apoio que precisam para escrever suas reportagens (press release, infográficos) e falam com o principal autor do estudo com facilidade - mesmo que seja um cientista renomado com prêmio Nobel” (RIGHETTI, 2018, p.27). A autora chama atenção, contudo, para a falta de iniciativas como essas a nível nacional, pois, como é de se esperar, a plataforma EurekAlert prioriza, sobretudo, as produções científicas estadunidenses. Então, além desse tipo de plataforma poder ser vista como parte de um processo homogeneizante da produção midiática sobre ciência, ainda acaba por excluir as inúmeras contribuições de cientistas brasileiros na produção científica. Entendendo que a confrontação de perspectivas é fundamental para compor uma visão crítica sobre o que é veiculado na mídia, é fundamental que seja chamada a atenção para o pouco uso do contraditório nos materiais midiáticos sobre ciência, além da suposta tendência homogeneizante desses materiais entre os diversos meios de comunicação.

Além do destaque às agências de notícia, e da influência que um jornalista ou um dado meio de comunicação tem um sobre os outros, também é importante perceber que a produção da mídia depende das imagens que se constroem sobre os leitores, telespectadores, ouvintes, etc. Claudio Bertolli Filho, para compreender esta questão da imagem projetada dos interlocutores, começa por apresentar o manual de redação, publicado em 2001, de um dos mais importantes jornais do Brasil, a Folha de SP. De acordo com Bertolli (2006), a principal relação que se busca estabelecer entre emissor e receptor está relacionada aos interesses empresariais. Para defender esse ponto de vista, destaca a seguinte passagem do manual: “Leitor é quem sustenta, em última análise, o jornal. Leitor primário é aquele que o compra. Leitor secundário é aquele que tem acesso ao jornal, embora não tenha o hábito de comprá-lo" (Manual de Redação Folha de SP, 2001, p. 45 apud BERTOLLI, 2006, p. 17). A partir dessa declaração, a redação deste jornal tende, de acordo com o autor, a poupar ao máximo o leitor de possíveis dificuldades. 
Como comprador de uma mercadoria, o leitor deve ser poupado o máximo possível de qualquer dificuldade, cabendo ao jornalista servir-se de uma linguagem apropriada e também de gráficos, quadros sinópticos, mapas e imagens, dentre outros recursos para, mais do que tornar inteligível a matéria, cumprir o que a Folha de S. Paulo assumiu declaradamente como sendo sua "filosofia editorial": poupar trabalho ao leitor. (BERTOLLI, 2006, p. 17)

Esse posicionamento, de simplificação da linguagem, ganha curso ainda mais nítido no território do jornalismo científico. Ainda de acordo com Bertolli, "observa-se uma forte tendência de os leitores das matérias sobre ciência serem representados como 'analfabetos científico" (BERTOLLI, 2006, p. 17). Além disso, existe uma busca incansável por audiência. Essa busca não deve ser vista apenas pela relação comercial, embora em muitas ocasiões seja ela a predominante. De maneira geral, buscamos tanto em comunicação quanto na educação, o engajamento das pessoas nos temas que julgamos importantes. Neste sentido, existe nas produções da mídia uma busca pelo sensacional, como já mencionamos no capítulo 3. Contudo, as dificuldades da mídia em estabelecer o perfil do público consumidor do noticiário científico e em como ampliar o número de indivíduos interessados em ciências "têm coagido seus profissionais a recorrerem às formulas consagradas pelos meios de comunicação de massa, especialmente a espetacularização do saber e da prática científica, avizinhando-se arriscadamente da divulgação da pseudociência” (BERTOLLI, 2006, p. 19).

Para compor uma visão crítica acerca da produção da mídia sobre ciência, também é importante perceber que existem diferentes e variados critérios no processo de seleção das informações, produção e publicação de uma notícia sobre ciência. A partir das obras de Hiller Krieghbaum (1970), Warren Burkett (1990) e Alton Blakeslee (1996), Bertolli indica alguns desses critérios. Destacaremos a seguir alguns desses critérios, tomando exemplos atuais para ilustrar cada um deles.

Um dos critérios adotados é o "senso de oportunidade". Este critério se dá quando assuntos já "vencidos", isto é, que ocorreram em um passado 
próximo ou distante, voltam a despertar interesse. Podemos exemplificar este critério com a atenção dada aos manuscritos de Galileu encontrados em 2018 e que tiveram repercussão na mídia. Tratou-se de uma carta de Galileu que, supostamente, mostraria que o físico italiano teria "editado" suas ideias heréticas para enganar a inquisição ${ }^{25}$. Isto é, um caso antigo, relação de Galileu com a Igreja, ganha um novo elemento de discussão, configurando um "senso de oportunidade" para abordar esse assunto na mídia.

Outro critério é o "Timing", que ocorre quando um evento externo aos novos acontecimentos científicos chama a atenção pública. Como exemplo, poderíamos citar o acidente nuclear de Fukushima, que proporcionou à mídia espaço para falar não só do acidente em si, mas da produção de energia, do funcionamento e dos riscos das usinas nucleares.

Também é critério o "impacto" que determinado assunto pode causar em um grande número de pessoas. Neste quesito, destacam-se os assuntos focados na medicina e saúde, mesmo que não apresentem novidades. Assim, avaliações sobre o estado em que se encontram as pesquisas sobre o câncer ou outras doenças, sobre sexualidade, etc. são regularmente invocadas na mídia.

O pioneirismo é uma das buscas de todo jornalista. Não é diferente de quem produz notícias com assuntos científicos. Para tal, é necessário que o jornalista tenha contato próximo com os laboratórios e com pesquisadores e saiba avaliar com destreza as informações que chegam a ele. Contudo, como afirmamos anteriormente, tem sido cada vez mais comum o uso de agências ou de plataformas como a "EurekAlert", o que torna o "furo de reportagem" algo mais difícil para o jornalista que trabalha com ciência.

Outro critério amplamente utilizado é o de "personagens célebres": entrevistas com autoridades científicas ou profissionais que acumularam prestígio em sua área de atuação chamam a atenção do público. No Brasil, podemos dar destaque a figuras como o engenheiro Marcos Pontes, atual

\footnotetext{
${ }^{25}$ A primeira reportagem sobre o trabalho dos historiadores que encontraram esta carta foi publicada pela revista Nature. Disponível em: https://www.nature.com/articles/d41586-018-06769-4
} 
ministro de Ciência e Tecnologia do Brasil, que ganhou destaque por ser o primeiro brasileiro em uma missão fora da Terra, e o médico Antônio Drauzio Varella, conhecido por popularizar informações sobre medicina em vários canais de comunicação, dentre outros. Também podemos destacar a recorrência de materiais desenvolvidos sobre "grandes figuras" da ciência, como Einstein, Galileu, Darwin etc.

Para Bertolli, o "conflito" também é um critério para a produção midiática, uma vez que situações de confronto também chamam a atenção do leitor. Para o autor, tal recurso ganha destaque principalmente quando ocorre um confronto ético entre cientistas. Por exemplo, acusações de plágio e o debate sobre o uso de cobaias em pesquisa científica são recorrentes na mídia.

Bertolli destaca mais critérios do que apresentamos acima. Nossa intenção não é criar uma lista exaustiva de critérios adotados para a seleção, produção e disseminação de assuntos sobre a ciência na mídia, mas sim o de chamar a atenção de que existem critérios para tal. E, invariavelmente, esses critérios estão atrelados à busca por ampliar o público que entrará em contato com o material desenvolvido.

\subsection{Olhar crítico para a Ciência}

A literatura em ensino de ciências tem apontado que além da necessidade de ensinar ciência, temos que ensinar sobre ciência. Entendemos essas indicações como a necessidade de aprofundarmos, com nossos alunos, além das teorias e conceitos científicos, questões relacionadas aos desdobramentos da ciência na organização social e debater aspectos relacionados à natureza da ciência, sua dinâmica de produção, etc. Isto é, deslocar o objetivo do ensino de ciência para a compreensão e atuação fundamenta em um mundo cada vez mais marcado pela presença da ciência e da tecnologia, o que Roberts (2007) classificaria como visão II da Alfabetização Científica. Cachapuz, Gil-Perez, Carvalho, Praia e Vilches, na obra "A necessária renovação do Ensino de Ciências", defendem o caráter de objetivo social prioritário da educação científica na sociedade atual, tanto 
para a preparação de futuros cientistas, como para a formação de cidadãos e cidadãs suscetíveis de participar na tomada fundamentada de decisões em torno de problemas sócio-científicos e sócio-tecnológicos cada vez mais complexos. A partir da literatura, os autores indicam que há "uma convergência básica de diferentes autores na necessidade de ir mais além da habitual transmissão de conhecimentos científicos, de incluir uma aproximação à natureza da ciência e à prática científica e, sobretudo, de enfatizar as relações ciência-tecnologia-sociedade-ambiente, de modo a favorecer a participação dos cidadãos na tomada fundamentada de decisões (CACHAPUZ et al, 2005, p. 23).

Um dos principais argumentos defendidos por quem entende que a educação científica deve fazer parte de uma formação mais ampla dos cidadãos e cidadãs, sobretudo preparando-os para a atuação no mundo do qual são integrantes, é o argumento democrático. Isto é, uma educação científica voltada a possibilitar tomadas de decisões fundamentadas diante de questões que envolvam ciência e tecnologia. Este ponto é, contudo, controverso. Para alguns autores, o nível de conhecimento específico para que seja possível se posicionar diante de um problema envolvendo ciência e tecnologia não seria possível de ser alcançado na educação básica, restando aos especialistas tomar decisões diante de determinados problemas. É claro que não podemos ignorar a complexidade dos conceitos científicos implicados em problemas reais como, por exemplo, o aquecimento global. Mesmo entre os cientistas, temos especialistas de diversas modalidades para compor um entendimento de um fenômeno complexo e amplo como este. Seria irrealizável uma formação básica que pretendesse aprofundar todos os conceitos e teorias que perpassam o entendimento deste problema. Contudo, como defendem Cachapuz e colaboradores (2005), a participação e a tomada fundamentada de decisão necessita, por parte dos cidadãos e cidadãs, "mais do que um nível de conhecimento muito elevado, a vinculação de um mínimo de conhecimentos específicos, perfeitamente acessível a todos, com abordagens globais e considerações éticas que não exigem especialização alguma” (CACHAPUZ et al, 2005, p. 25). 
Neste sentido, entendemos que tão importante quanto saber conceitos básicos da ciência, é fundamental que seja debatido as condições de produção da ciência, tanto do ponto de vista de sua dinâmica interna quanto de suas influências e desdobramentos na sociedade. Em outras palavras, defendemos que ensinar ciências tendo objetivos sociais como interesse passa por compreender aspectos epistemológicos da ciência, assim como suas relações com a economia, com a política, com a cultura, etc.

A literatura tem mostrado a existência de concepções ingênuas a respeito da dinâmica de funcionamento da ciência, como o entendimento de que a ciência é um conhecimento inquestionável, construído com base em um método científico universal que garante sua confiabilidade. Tomando a perspectiva de uma educação científica interessada na participação democrática e fundamentada dos cidadãos e cidadãs, é necessário que a concepção de ciência como um conhecimento inquestionável seja problematizada. Essa problematização deve estar comprometida com a busca da superação de tal visão, uma vez que esta concepção pode levar à decisões que eventualmente ferem aos interesses públicos, em nome de uma pretensa verdade científica. É fundamental que se compreenda que a ciência empreende diversos métodos para a construção de conhecimento. Além disso, é importante que se delimite as condições de contorno de cada teoria, discutindo seus campos de validade.

Atrelada à ideia de que a ciência é construída a partir de um método científico único e infalível, está a ideia de que a ciência progride a partir de descobertas. Essa é uma versão particularmente muito difundida na mídia. Embora os experimentos sejam primordiais na dinâmica da ciência, é necessário que sejam exploradas as influências teóricas e tecnológicas na concepção e análise dos experimentos. A ciência não atua através do simples desvelamento da realidade, de forma neutra. O mundo natural é interpretado através da ciência. Como defendia Norwood Hanson (1979), observação e interpretação são processos indissociáveis na construção da ciência. Não há como pensar um sem o outro. 
Outra concepção ingênua da ciência, também amplamente explorada na literatura, é a figura do gênio. Existe, no imaginário popular, um entendimento de que a ciência é produzida apenas por figuras ilustres, tais como Newton, Galileu, Darwin, Lavoisier, Einstein, etc. Esta concepção reforça ainda mais o entendimento da ciência como corpo de conhecimento inquestionável e infalível. Além disso, dificulta que as pessoas se identifiquem com a ciência, uma vez que apenas gênios estariam propensos à atividade científica. Sem identificação, ou possibilidade de crítica à própria ciência, acreditamos ser impossível posicionar-se diante de problemas reais que envolvem ciência e tecnologia.

A literatura também indica que existe a difusão de uma visão ahistórica e aproblemática da ciência: "[...] transmitem-se os conhecimentos já elaborados, sem mostrar os problemas que lhe deram origem, qual foi a sua evolução, as dificuldades encontradas, etc." (GIL PEREZ et al, 2001, p. 131). Não reconhecer o caráter histórico de construção da ciência implica não reconhecer as limitações atuais do conhecimento científico nem as perspectivas que se abrem a partir da prática científica. Esta é uma concepção construída, principalmente, pela omissão de uma perspectiva histórica que reconheça a ciência como uma atividade em permanente construção. O reconhecimento histórico de construção da ciência está atrelado, muitas vezes, a uma visão acumulativa e de crescimento linear de seu corpo de conhecimento, ignorando as crises e as remodelações profundas pelas quais passou a ciência.

Outra concepção que a literatura identifica como sendo amplamente difundida é a visão de uma ciência socialmente neutra, como se os cientistas estivessem "acima do bem e do mal". É fundamental, principalmente tendo o mundo social como referência para o ensino de ciências, buscar estabelecer relações entre ciência e os interesses sociais mais amplos, suas relações com a tecnologia, etc. São vários os aspectos que devem ser abordados em busca de problematizar as relações entre ciência, tecnologia e sociedade, como analisar como as teorias científicas são ou poderiam ser articuladas para fundamentar ações políticas, como por exemplo relacionadas à preservação 
do meio ambiente, às crises energéticas, à produção de alimentos de maneira mais eficiente e com menos usos de agrotóxicos, à diagnósticos e tratamento de doeças, etc. Além disso, a ciência como uma atividade inserida na sociedade, depende de uma série de fatores concretos, como seu financiamento, a formação de cientistas, a valorização do conhecimento, etc.

Assim, defendemos que o desenvolvimento de posturas críticas sobre a ciência passa tanto pela compreensão de aspectos relacionados à sua dinâmica interna, como perceber as influências e desdobramentos externos à ciência, frisando a atividade científica como estando inter-relacionada com outras atividades e interesses humanos.

\subsection{Síntese}

Uma das questões de fundo desta tese é a seguinte: "Por que Ensinar Ciências/Física em nossa atual sociedade?" Em nossa revisão dos trabalhos sobre Alfabetização Científica concluímos que os debates apresentados na literatura estão inseridos em uma série de tensões e disputas relacionadas aos objetivos educacionais atribuídos ao ensino de ciências, a tensões que representam as condições concretas às quais estão submetidas as reflexões educacionais, a tensões sobre metodologias (de pesquisa e de ensino), à heterogeneidade de contextos e de públicos a quem se destina o ensino de ciências etc. Consideramos que essas tensões sempre estarão presentes na educação científica e, portanto, nas discussões sobre AC. São tensões não superáveis, mas que têm potencial de promover o diálogo entre pesquisadores e educadores em ensino de ciências, condição indispensável à produção de conhecimento e à prática educacional.

Assim, reconhecendo que o debate sobre AC está inserido em uma série de tensões intrínsecas à educação científica, consideramos que existe uma necessidade constante de diálogo e contextualização sobre esta temática. Defendemos que este constante diálogo deve se dar a partir de problemas e conflitos que estão relacionados, principalmente, aos desafios da formação de pessoas pertencentes ao seu tempo, que busquem a 
compreensão do mundo que as cercam, sobretudo para que possam participar de maneira crítica e democrática de decisões em que estão implicadas. Assim, uma das questões essenciais que deve perpassar os diálogos sobre a $\mathrm{AC}$, e que faz parte das tensões a que nos referimos, é a seguinte: Quais são os problemas emergentes do mundo hoje?

Procuramos defender ao longo dos capítulos 2 e 3 que um dos problemas emergentes do mundo hoje envolve as relações estabelecidas entre as pessoas e a mídia: quais narrativas sobre o mundo (político, cultural, social, científico, tecnológico, etc) as pessoas têm acesso? Como se relacionam com estas narrativas? São apenas passivas das narrativas contadas por grandes conglomerados de comunicação ou têm possibilidades de criar suas próprias narrativas através da mídia?

A principal proposição desta tese é que os materiais de mídia devem ser problematizados nas aulas de Física, de modo que os estudantes sejam capazes de identificar vieses e interesses na produção midiática, reconhecendo sua não neutralidade. Para o exercício de uma leitura crítica da mídia defendemos como condição a comparação entre diferentes produções sobre um mesmo tema, para que seja possível compor uma visão mais complexificada e que identifique, eventualmente, tensões entre diferentes perspectivas. Ser capaz de criticar as narrativas da mídia passa por reconhecer, como defendia Paulo Freire, que a produção midiática não é boa e nem má em si mesma, mas que potencialmente serve a interesses. Assim, questionar a serviço "do quê" e a serviço "de quem” as mídias estão, implica questionar sobre o poder exercido pela e através da mídia, sendo, portanto, questionamentos políticos.

Para problematizar a mídia também é fundamental que se reconheça os recursos de linguagem empreendidos para que as narrativas sejam construídas. Por exemplo, é comum em materiais midiáticos sobre ciência que se use metáforas como recurso linguístico. Os usos da linguagem na mídia podem ter vários vieses, como capturar nossa atenção, provocar nossas emoções, persuadir-nos a determinadas compreensões e pontos de 
vista etc. Além disso, existe o desafio de passar de uma linguagem específica e complexa como a da Ciência, para uma linguagem destinada a um público de não especialistas. Essa tentativa de passar de uma linguagem à outra pode implicar em um processo de simplificação. O problema central da simplificação é que ela pode comprometer a precisão das teorias e conceitos científicos construídos a partir da linguagem da Ciência.

Ainda em relação à dinâmica de produção da mídia, é importante percebermos a utilização de sensacionalismos e frases de efeito. A jornalista Mônica Teixeira (2002) afirma categoricamente que o jornalismo sobre ciência é sensacionalista, ponderando que "o acontecimento que não causa espanto, uma sensação, não preenche os requisitos da notícia" (TEIXEIRA, 2002, p. 140). Contudo, a busca por causar sensações pode resultar em uma extrapolação da realidade e produzir um verdadeiro espetáculo sobre os fatos. Do ponto de vista pedagógico, no entanto, as produções sensacionalistas podem proporcionar a problematização de um dado tema científico e fomentar a discussão sobre os processos de produção da mídia (RIBEIRO \& KAWAMURA, 2008, p.7).

Entendemos que a inserção da mídia em aulas de física deve ir além do mero uso instrumental de materiais midiáticos em sala de aula. Buscamos uma aproximação entre a Educação para as Mídias e o Ensino de Ciências como estratégia para a constituição de olhares críticos tanto da Mídia quanto da Ciência e, em última instância, um olhar crítico para o mundo onde essas relações se dão a partir de diferentes tensões e através de disputas de poder. Para Michelle Prazeres (2009), a superação de compreensões instrumentalistas ou utilitaristas passa por considerar a comunicação "não somente em relação a seus instrumentos, mas em relação a seu poder, seu domínio, sua centralidade nos dias de hoje" (PRAZERES, 2009, p. 7). A aproximação entre a educação para as mídias e o ensino de ciências deve considerar que as mídias são responsáveis por um processo de transmissão, negociação e apropriação de saberes que podem contribuir para manter ou transformar grupos e sociedades. Esse olhar representa um 
entendimento sobre as mídias e seu lugar na sociedade e na formação dos indivíduos, que deve ir além de usos instrumentais de materiais da mídia. Assim, devemos considerar os materiais midiáticos "não apenas como instrumentos a serem manejados corretamente e que, para isso, requerem um aprendizado. Não apenas como meios que, utilizados, promovem uma leitura diferenciada do processo de produção midiática. Mas como processos que determinam - em diálogo ou tensão com outras instituições socializadoras - a forma como se constrói o pensamento e o conhecimento hoje e a forma com que os indivíduos se relacionam entre eles e com o mundo" (PRAZERES, 2009, p.7). Isto é, não podemos considerar a comunicação como um processo bancário, utilizando a mídia não como meio de comunicação, mas como meio em que se reduz a transmissão de informações a "comunicados", de maneira unidirecional (FREIRE \& GUIMARÃES, 2011, p.146). Trata-se de buscar possibilidades de uma comunicação com potencial emancipatório, em que todos possam receber informações criticamente, produzir comunicação, se comunicar e circular suas produções (PRAZERES, 2009, p.7).

A aproximação entre a educação para as mídias e o ensino de ciências deve buscar, além de reflexões críticas e analíticas sobre os meios de comunicação e as possibilidades de atuação crítica e criativa através das mídias, a problematização do próprio conhecimento científico e de suas relações com o desenvolvimento tecnológico e com a organização social de maneira mais ampla. Entendemos ser fundamental na problematização da ciência veiculada na mídia a discussão de características epistemológicas do conhecimento científico, de modo que sejam superadas visões estereotipadas da ciência, tais como a "mitologia dos resultados" que representa o fazer científico apenas por seus produtos, "ignorando os processos (históricos, sociais e culturais) e os procedimentos (metodológicos) inerentes à atividade científica; na compreensão dos resultados das pesquisas como decorrentes de procedimentos cumulativos e finalistas [...]" (RIBEIRO \& KAWAMURA, 2008, p.4), a crença em um método científico único e universal, o "mito do gênio" que identifica apenas grandes nomes como Einstein, Newton, Galileu 
etc, como responsáveis pela construção de conhecimento científico, dentre outras.

Além de um aprofundamento em relação a aspectos epistemológicos relacionados à dinâmica de produção e funcionamento da ciência, a aproximação entre as perspectivas da educação para as mídias e o ensino de ciências deve problematizar os desdobramentos tecnológicos, sociais e ambientais implicados nas temáticas científicas abordadas pela mídia.

Como indicamos no capítulo 3, a formação de professores é condição sine qua non na busca por inserir perspectivas da educação para as mídias no ensino de ciências, como estamos propondo nesta tese. Assim, além da dimensão midiática e da própria ciência, temos que negociar as tensões geradas por essa aproximação nas práticas de ensino. Em outras palavras, é indispensável que a busca pela problematização da mídia e da ciência em aulas de física se dê a partir de práticas de ensino que valorizem o diálogo como fundamento das atividades propostas e que busquem o desenvolvimento de possibilidades de participação criativa, e não passiva, dos alunos. Um dos desafios, portanto, é negociar as tensões e conflitos gerados entre os fundamentos educacionais adotados nesta tese e as condições concretas e materiais em que estão inseridos os professores em formação.

Assim, a aproximação entre as perspectivas da educação para as mídias e o ensino de ciências na formação de professores deve considerar três eixos interdependentes: Mídia, Ciência e Ensino.

A seguir apresentaremos o contexto no qual desenvolvemos práticas de ensino que buscaram a aproximação de perspectivas da educação para as mídias e do ensino de ciências na formação de futuros professores de física. Apresentamos, neste mesmo capítulo, a metodologia da análise textual discursiva, que embasou nossa análise dos materiais produzidos pelos licenciandos. 


\section{Capítulo 6}

\section{Campo, Corpus e referencial}

\section{metodológico da pesquisa}

Para a consecução dos objetivos apresentados nesta tese, qual seja, o de inserir e analisar o debate da educação para as mídias na formação de professores de Física, a investigação foi realizada em duas disciplinas do curso de licenciatura em Física do Instituto Federal de Educação, Ciência e Tecnologia de São Paulo (IFSP), campus São Paulo. Uma delas, ministrada no primeiro semestre de 2018, foi a disciplina Introdução ao Ensino e Divulgação da Ciência (EDCZ2), obrigatória e destinada a alunos do segundo semestre da licenciatura em Física, com cinco aulas semanais de 45 min cada. A outra disciplina, também obrigatória (embora os licenciandos possam optar entre duas possibilidades), denominada genericamente de Oficina de Projetos de Ensino (PE1), oferecida a alunos do quinto e sétimo semestres do curso de licenciatura em Física e ministrada no segundo semestre de 2018, também com cinco aulas semanais de 45 minutos cada. Das cinco aulas semanais, duas eram destinadas ao estágio dos estudantes. Essa é uma disciplina aberta da grade curricular do curso de licenciatura em física do IFSP, isto é, a ideia é que a cada semestre os professores possam sugerir abordagens diferentes a essa disciplina, focando em diversas perspectivas para o ensino de física, como, por exemplo, ensino de física por investigação, experimentação, história e filosofia da ciência, gamificação etc. Nossa proposta de oficina de projetos de ensino consistiu em inserir o debate da educação para as mídias, propondo-nos a construir junto com os alunos intervenções em sala de aula, já que a disciplina é vinculada ao estágio obrigatório. Intitulamos a disciplina de Problematizando a ciência na mídia.

O corpus da pesquisa foi constituído, assim, pelas produções dos alunos dessas duas disciplinas, ministradas pelo proponente desta tese no 
primeiro e segundo semestres de 2018. O material coletado foi analisado à luz do referencial metodológico da análise textual discursiva, particularmente como proposto por Moraes (2003) e Moraes e Galiazzi (2006).

Neste capítulo apresentaremos os documentos que foram objeto de análise, assim como o referencial da análise textual discursiva e as categorias de análise decorrentes do referencial teórico dessa tese. Apresentamos inicialmente o contexto no qual foi desenvolvida a pesquisa. Em seguida apresentamos os materiais que compõem nossa análise. Por último, apresentamos a metodologia da análise textual discursiva.

\subsection{Campo}

\subsubsection{Disciplina Introdução ao ensino e divulgação da Ciência (EDCZ2)}

Nesta seção pretendemos descrever em detalhes o desenvolvimento da disciplina EDCZ2, ministrada no primeiro semestre de 2018. Vale salientar, de partida, que a disciplina aborda questões de ensino e divulgação da ciência que transcendem a discussão desta tese, focada, sobretudo, na relação da educação para as mídias e a educação científica.

Apresentamos abaixo a grade curricular do curso de licenciatura ${ }^{26} \mathrm{em}$ Física do IFSP27, de modo que seja possível compreender minimamente o contexto em que a disciplina EDC se enquadra.

\footnotetext{
${ }^{26} \mathrm{O}$ documento oficial pode ser encontrado a partir do link: https://spo.ifsp.edu.br/images/phocadownload/DOCUMENTOS MENU LATERAL FIXO/GRADUACAO/LI CENCIATURA FISICA/EC Lic Fisica SPO nov2008.pdf . Último acesso em 19/02/2019 às $10 \mathrm{~h} 24$.

${ }^{27}$ O currículo da Licenciatura em Física do IFSP foi reformulado. Assim, a grade apresentada aqui vale para os ingressantes até o primeiro semestre de 2018.
} 


\begin{tabular}{|c|c|c|c|}
\hline Semestre & Disciplina & Semestre & Disciplina \\
\hline 1 & 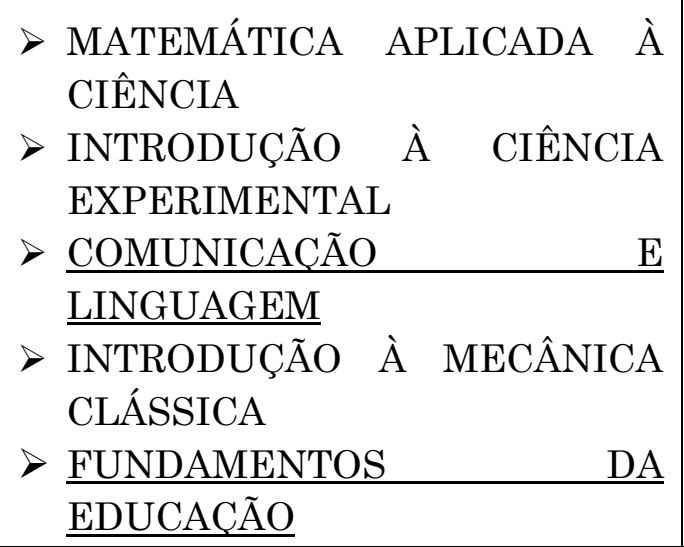 & 2 & 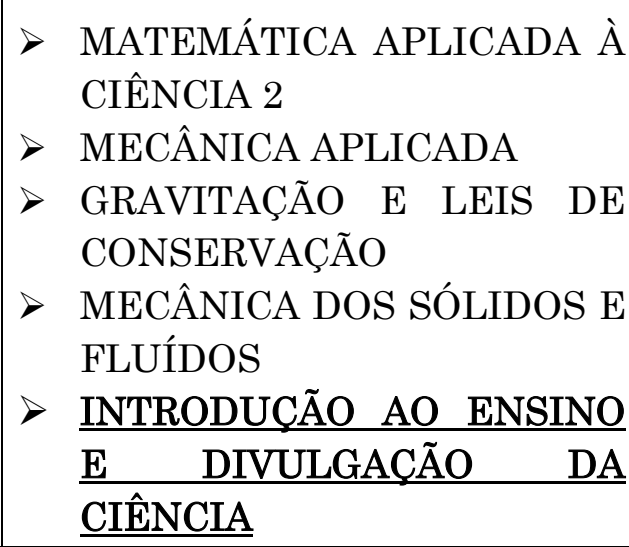 \\
\hline 3 & $\begin{aligned}> & \text { MATEMÁTICA APLICADA À } \\
& \text { CIÊNCIA } 3 \\
> & \text { ELETRICIDADE E CIRCUITOS } \\
& \text { ELÉTRICOS } \\
> & \text { FENÔMENOS } \\
& \text { ONDULATÓRIOS } \\
> & \text { TERMODINÂMICA } \\
> & \text { ESTATÍSTICA APLICADA À } \\
& \text { CIÊNCIA E À EDUCAÇÃO }\end{aligned}$ & 4 & $\begin{array}{rlr}> & \text { MATEMÁTICA APLICADA À } \\
& \text { CIÊNCIA 4 } \\
> & \text { FUNDAMENTOS } & \\
& \text { ELETROMAGNETISMO } \\
> & \text { CULTURA POLÍTICA } & \mathrm{E} \\
& \text { FORMAÇÃO } & \text { DE } \\
& \text { PROFESSORES } \\
> & \text { ÓPTICA } \\
> & \text { EPISTEMOLOGIA } \\
& \text { ENSINO DA CIÊNCIA } & \\
\end{array}$ \\
\hline 5 & $\begin{aligned}> & \text { POLÍTICA E ESTRUTURA DO } \\
& \text { ENSINO NO BRASIL } \\
> & \text { ESTRUTURA DA MATÉRIA } \\
> & \text { FÍSICA E CIÊNCIAS DA VIDA } \\
> & \text { INTRODUÇÃO À } \quad \text { FÍSICA } \\
& \text { MODERNA } \\
> & \text { OFICINA DE PROJETOS DE } \\
& \text { ENSINO 1 }\end{aligned}$ & 6 & $\begin{array}{l}>\text { FÍSICO-QUÍMICA } \\
>\text { FÍSICA ATÔMICA E } \\
\text { MOLECULAR } \\
>\text { CIÊNCIA, HISTÓRIA E } \\
\text { CULTURA } \\
>\text { ESCOLA E SOCIEDADE } \\
>\text { OFICINA DE PROJETOS DE } \\
\text { ENSINO 2 }\end{array}$ \\
\hline 7 & $\begin{aligned}> & \text { FÍSICA NUCLEAR E DE } \\
& \text { PARTÍCULAS } \\
> & \text { FÍSICA DO ESTADO SÓLIDO } \\
> & \text { EDUCAÇÃO CIENTÍFICA E } \\
& \text { PRÁTICA DE ENSINO } 1 \\
> & \text { OFICINA DE PROJETOS DE } \\
& \text { ENSINO } 3\end{aligned}$ & 8 & $\begin{aligned}> & \text { FÍSICA E CIÊNCIAS DA } \\
& \text { TERRA } \\
> & \text { ASTRONOMIA } \\
> & \text { EDUCAÇÃO CIENTÍFICA E } \\
& \text { PRÁTICA DE ENSINO } 2 \\
> & \text { OFICINA DE PROJETOS DE } \\
& \text { ENSINO } 4\end{aligned}$ \\
\hline
\end{tabular}

Como podemos notar pelo quadro apresentado, a disciplina EDCZ2 é a primeira disciplina específica relacionada ao Ensino de Ciências com que os 
licenciandos têm contato (considerando o período ideal), e a única direcionada explicitamente à divulgação científica em toda a grade do curso.

\section{A seguir reproduzimos integralmente a ementa da disciplina EDCZ2,} que apresenta alguns dos objetivos apresentados no capítulo anterior.

Visando à autonomia docente, do profissional reflexivo ao intelectual crítico, este espaço curricular encontra-se diretamente voltado à compreensão da prática reflexiva do professor enquanto instância formadora, articulando o trabalho da sala de aula com a atuação de outras instituições voltadas à popularização da ciência tais como museus, jornais, revistas, literatura, cinema, exposições, artefatos e ambientes lúdicos etc. A problematização dos espaços alternativos de divulgação científica e a elaboração de atividades didáticas que interajam com alunos da educação básica compõem este espaço curricular que visa: A concepção e promoção de práticas educativas compatíveis com os princípios da sociedade democrática, a difusão e aprimoramento de valores éticos, o respeito e estímulo à diversidade cultural e a educação para a inteligência crítica; $\underline{a}$ compreensão dos códigos e linguagens da divulgação científica e a sua inserção na realidade social e cultural contemporânea voltadas à formação e consolidação da cidadania; $\underline{\text { o domínio de conteúdos }}$ disciplinares específicos, da articulação interdisciplinar, multidisciplinar e transdisciplinar dos mesmos, tendo em vista a natureza histórica e social da construção do conhecimento e sua relevância para a compreensão do mundo contemporâneo; a condução da atividade docente a partir do domínio de conteúdos pedagógicos aplicados às áreas e disciplinas específicas a serem ensinadas, da sua articulação com temáticas afins e do monitoramento e avaliação do processo ensino-aprendizagem; $\underline{o}$ desenvolvimento da atitude crítico-reflexiva em relação aos problemas sociais da Ciência; Aprender os conceitos básicos da divulgação científica. Promover discussões sobre o significado da reflexão em educação, discutindo diferentes dimensões da prática reflexiva.; Desenvolver com os alunos diferentes estratégias de ensino de ciências da natureza, permitindo que o licenciando ouse propor uma aula que se aproprie de seu discurso que defende uma mudança na conduta do professor em sala de aula. Abordagem das relações interpessoais numa sala de aula e numa escola como um 
fenômeno social complexo que agrega, portanto, diferentes ciências na sua leitura. Compreensão dos códigos e linguagens da divulgação científica; a Identificação de fontes de informação e formas de obter informações relevantes para o conhecimento da Ciência; Reconhecer ou propor a investigação de problemas relacionados à Ciência, selecionando práticas pedagógicas pertinentes. (Projeto de Curso da Licenciatura em Física IFSP SPO, p.44, grifos nossos).

A disciplina EDCZ2 prevê uma carga horária total de 75h, distribuídas em cinco aulas (45 minutos cada) por semana, que foram divididas em três aulas em um dia e duas aulas em outro. O proponente da tese acumulou neste contexto as funções de Professor e Pesquisador.

Podemos notar que a disciplina deve versar sobre a divulgação científica de maneira geral, destacando as diferentes formas pelas quais ela é concretizada. Com isto, a discussão da divulgação científica na mídia, e as perspectivas da educação para as mídias de maneira mais ampla, consta apenas como uma parte da disciplina.

A seguir apresentamos o desenvolvimento da disciplina aula a aula, descrevendo as metodologias e os referenciais adotados para as discussões, assim como anotações gerais sobre a repercussão dos temas propostos aos licenciandos.

Iniciamos a disciplina com uma discussão geral sobre educação científica, partindo de uma questão que consideramos fundamental: Por que ensinar Física em nossa sociedade atual? Em um primeiro momento, defendemos a importância deste questionamento para uma atuação refletida e consciente do trabalho como educadores. Antes de apresentarmos alguns dos objetivos apontados na literatura de ensino de ciências, propusemos a reflexão e debate em pequenos grupos em torno da questão apresentada, para, então, cada grupo apresentar suas motivações para o ensino de ciências. Durante as discussões os alunos desenvolveram argumentos relativamente bem elaborados. As principais perspectivas apontadas foram: compreensão de fenômenos do dia a dia, como funcionamento do chuveiro, o 
que é um relâmpago, etc; preparação para a atuação crítica na sociedade (sem muito aprofundamento sobre o sentido de "atuação crítica"); desmistificar o cientista: foi muito presente no debate a crítica à visão de cientista no senso comum, especialmente relacionado ao "mito do gênio"; apareceram, com menor intensidade, algumas justificativas pragmáticas como a preocupação com o desempenho no vestibular. Essas discussões foram alocadas em cinco aulas.

$\mathrm{Na}$ sequência propusemos uma síntese das discussões em uma aula expositiva, na qual, além de retomarmos alguns pontos levantados pelos próprios alunos, apresentamos diferentes abordagens do que a literatura chama de "Alfabetização Científica". Focamos na pluralidade deste termo, que evidencia, a nosso ver, a pluralidade de objetivos para o ensino de ciências. A fundamentação teórica desta aula foi, basicamente, a apresentada na introdução desta tese. Foi proposto aos alunos que lessem e produzissem uma resenha do capítulo 1 do livro "A Necessária Renovação do Ensino de Ciências", dos autores Antonio Cachapuz, Daniel Gil Perez, Ana Maria Pessoa de Carvalho e Amparo Vilches. O capítulo referido é intitulado Importância da educação científica na sociedade actual ${ }^{28}$ e compõe a primeira parte do livro que versa sobre $A$ educação científica como objectivo social prioritário.

Na sequência do curso, passamos a discutir a educação para além de seus processos formais, sobretudo pautados na instituição escolar. Ao todo, foram destinadas cinco aulas para discutirmos as diferenciações entre "Educação Formal”, "Educação Não-Formal” e "Educação Informal”. Esse conjunto de aulas foi fundamentado, particularmente, na obra "Educação Formal e Não-Formal" (2008) de Jaume Trilla e Elie Ghanem, organizado por Valéria Amorim Arantes. As aulas foram ministradas de maneira expositiva. Com a intenção de fomentar o diálogo e a participação dos licenciandos durante as aulas expositivas, propusemos a leitura de trechos 
da obra mencionada acima antes das aulas, com a tarefa de desenvolverem resenhas críticas sobre os trechos selecionados.

A partir das discussões sobre Educação Não-Formal, pudemos inserir o debate sobre as diversas formas de divulgação da ciência. Como uma tentativa de primeiro mapeamento, sugerimos a análise de trabalhos apresentados no XXII SNEF (2017). Selecionamos trabalhos com o critério de abarcarmos diversas formas de divulgação científica: Museus, Teatro, Centros de Pesquisa, Grupos Itinerantes, etc. Cada grupo ficou responsável por analisar um artigo referente a um desses temas. Após a análise, cada grupo apresentou seu tema aos colegas da turma, de modo que todos pudessem ter um primeiro contato com essas diversas formas de divulgação científica.

Na sequência das aulas, retornamos a questões de ensino de ciências, focando neste momento nas discussões sobre "Natureza da Ciência". Este tema emergiu tanto dos debates sobre Alfabetização Científica como das críticas feitas às imagens de ciência que circulam em materiais de divulgação científica. O tema de Natureza da Ciência tem se constituído como uma área específica da filosofia da ciência e, também, uma área específica na pesquisa em ensino de ciências. Assim, cada vez mais os debates têm se especializado. Assim, buscamos referências, principalmente para indicação de leitura aos licenciando, que julgamos tratar o tema de maneira mais geral e didática. Tendo isto em vista, sugerimos que os alunos lessem o texto "Por uma visão não deformada do trabalho científico", de autoria de Daniel Gil Pérez, Isabel Montoro, Jaime Alis, António Cachapuz e João Praia. Durante a aula discutiu-se, dentre outras coisas, algumas perspectivas atuais do debate sobre Natureza da Ciência no ensino, como o debate entre aspectos consensuais e não consensuais da NdC. Focamos, sobretudo, nas principais visões "distorcidas" sobre o fazer científico, como a concepção empírico-indutivista da ciência, visão a-histórica, visão acumulativa e linear da produção da ciência, visão individualista e elitista e de uma prática científica socialmente neutra, dentre outras. Ao final, sugerimos que os alunos construíssem, em grupos, um quadro analítico, a 
partir das discussões da aula e do artigo sugerido, contendo as principais visões distorcidas da ciência apontadas pela literatura.

Esse quadro analítico foi utilizado, posteriormente, para analisar uma reportagem sobre a descoberta do bóson de Higgs, publicada na revista VEJA, intitulada "A incrível saga do Bóson de Higgs" 29. Em linhas gerais, os licenciandos apontaram para a presença de uma visão acumulativa da ciência, como se a descoberta do bóson de Higgs tivesse sido um desfecho de uma história linear que veio desde o Modelo Padrão até a construção do LHC (Large Hadron Colider). Além disso, algo recorrente na análise dos alunos foi a percepção de que a reportagem tratava a ciência como um conjunto de descobertas, em uma concepção empírico-indutivista.

Na sequência da disciplina, discutimos a divulgação da ciência em centros de pesquisa, tomando o caso do acelerador de partículas Pelletron da USP como exemplo. Em um primeiro momento organizamos a aula de maneira expositiva, tomando como principal fundamento da aula o artigo "Articulação Centro de Pesquisa - Escola Básica: contribuições para a Alfabetização Científica e tecnológica" (2010), de autoria de Giselle Watanabe-Caramello, Roseline Strieder, Graciella Watanabe e Marcelo Munhoz. Ao fim da aula propusemos a leitura de partes do texto preparado pelo Departamento de Física Nuclear da USP para Professores e Alunos que visitam o Pelletron ${ }^{30}$. A ideia era que os alunos pudessem ter uma ideia geral das atividades desenvolvidas neste centro de pesquisa para prepararem-se para uma visita ao Peletron. A visita ocorreu na semana seguinte à aula. Interessante notar que a visita proporcionou não apenas a aproximação com a Física Nuclear e o funcionamento do Pelletron, mas com questões mais amplas. Por exemplo, os licenciandos perguntaram coisas ao docente que nos recebeu, como: como era trabalhar ali, como poderiam fazer

\footnotetext{
${ }^{29}$ Disponível em: https://veja.abril.com.br/ciencia/a-incrivel-saga-do-boson-de-higgs/. Último acesso em 12/06/2019 às $17 \mathrm{~h} 45$.

${ }^{30}$ Disponível em:

https://portal.if.usp.br/fnc/sites/portal.if.usp.br.fnc/files/Texto\%20para\%20alunos\%20e\%20professores \%20que\%20visitam\%200\%20acelerador\%20Pelletron.pdf. Último acesso em 12/06/2019 às 18 h05.
} 
se quisessem fazer uma pós-graduação naquele laboratório, quem pagava a conta de luz do Pelletron, entre outras.

A disciplina continuou explorando mais formas de divulgação científica, focando neste momento, na divulgação científica em Histórias em Quadrinhos (HQ's). A aula focou, sobretudo, na leitura e análise da HQ "Alice no País dos Quarks", desenvolvida por pesquisadores do LHC. Na aula seguinte, discutimos a divulgação da ciência em letras de músicas. Ouvimos e discutimos algumas letras de músicas populares, como "Não pare na pista" e "Geração da Luz", de Raul Seixas, "Queremos Saber" e "Quanta", de Gilberto Gil, e “Tempo e Espaço”, de Paulo Vanzolini.

Continuando a exploração e aprofundamento em diferentes formas de divulgar a ciência, propusemos uma aula sobre a divulgação científica em desenhos animados. Foi proposta a leitura, durante a aula, de dois trabalhos publicados nos anais do XXII SNEF: Caracterização dos conteúdos presentes em programas televisivos de divulgação científica direcionados ao público infantil e Visões sobre cientistas veiculadas em desenhos animados infantis. A partir da leitura desses trabalhos, propusemos que os licenciandos, em grupos, preparassem uma aula de física a partir de um episódio de desenho animado qualquer.

A aula seguinte foi uma palestra de Professor convidado para falar da aproximação entre Ciência e Literatura.

Passamos, então, a discutir a divulgação científica em Museus de Ciências. Ao total foram dois encontros dedicados a este tema, totalizando 5 aulas expositivas. A aula foi fundamentada, sobretudo, nos trabalhos "Educação e Comunicação em Museus de Ciências: Aspectos históricos, pesquisa e prática" (2003), de Cibelle Cazelli, Martha Marandino e Denise Studart e "Educação em Museus: a mediação em foco" (2008), organizado por Martha Marandino.

Por fim, a etapa final da disciplina foi dedicada à divulgação da ciência na mídia. Inicialmente, propusemos dois encontros, totalizando cinco 
aulas expositivo-dialógicas sobre fundamentos da "educação para as mídias". Sugerimos que os alunos lessem o texto "Mídia, Escola e Leitura Crítica do Mundo", de Graça Caldas, antes desse conjunto de aulas. Durante a aula apresentamos parte dos trabalhos que constam no capítulo 3 desta tese. $\mathrm{Na}$ sequência, apresentamos algumas características mais específicas do jornalismo científico, pautados, sobretudo, no artigo de Bertolli (2006).

$\mathrm{Na}$ sequência, propusemos uma aula usando materiais de mídia. À guisa do "timing" das observações do eclipse solar que corroborou a teoria da relatividade geral, prestes a completar seu centenário, selecionamos textos midiáticos publicados no contexto das expedições inglesas que corroboraram a teoria de Einstein em 1919. Iniciamos a aula propondo a leitura de dois artigos do jornal Times London e um do New York Times, traduzidos pelo Professor e proponente desta tese. Os textos encontram-se anexados a esta tese. O objetivo da aula foi possibilitar aos licenciandos experimentarem uma possível maneira de introduzir materiais de mídia em uma aula de física. O foco da aula foi o de explorar o importante papel da mídia em ascender a imagem de Einstein ao mundo e discutir o contexto social e político no qual as expedições foram empreendidas. Uma análise mais detalhada desses materiais foi apresentada no capítulo 4.

Após esse conjunto de aulas, propusemos que os licenciandos, em grupos, preparassem aulas de física nas quais inserissem materiais de mídia. Tanto os temas quanto o tipo de material a ser selecionado foram de livre escolha dos grupos. A única exigência é que fossem selecionados, no mínimo, dois materiais diferentes para o mesmo tema. Os licenciandos apresentaram suas análises e propostas de aulas em seminários, que foram gravados com prévio consentimento. Além dos seminários, os licenciandos entregaram uma versão escrita de seus trabalhos, no qual constam as análises dos materiais midiáticos selecionados pelos grupos e os planos de aulas propostos a partir dessas análises. Tanto os vídeos quanto os textos compõem o corpus desta tese. Os detalhes desses materiais estão apresentados na seção "corpus". 


\subsubsection{Disciplina Problematizando a Ciência na Mídia}

Apresentaremos nesta seção o desenvolvimento da disciplina "Problematizando a Ciência na Mídia", ministrada no segundo semestre de 2018 pelo proponente desta tese. A disciplina foi proposta para a "Oficina de Projetos de Ensino 1 (PE1)", constante no currículo da licenciatura em Física do IFSP. Na tabela 1, apresentada na seção anterior, é possível notar que PE1 é oferecida no quinto semestre. E, no sétimo semestre é oferecida a disciplina "Oficina de Projetos de Ensino 3" (PE3). As disciplinas de "Oficinas de Projetos de Ensino" são abertas para que os Professores proponham suas abordagens a elas. São disciplinas atreladas ao estágio supervisionado obrigatório. PE1 exige $30 \mathrm{~h}$ de estágio, sendo que os licenciandos poderiam cumprir um mínimo de $22,5 \mathrm{~h}$ para sua aprovação (a diferença de 7,5h poderia ser compensada em outros estágios).

A disciplina conta com cinco aulas de 45 min por semana, sendo que duas delas são destinadas ao estágio. As duas aulas destinadas ao estágio também eram usadas para orientações individuais, quando os licenciandos não estavam na escola estagiando.

A cada semestre, Professores submetem seus projetos, que são negociados entre os colegas e aprovados pelo coordenador da licenciatura. Assim, a cada semestre essas disciplinas variam suas temáticas. Na prática, os alunos do quinto e sétimo semestres são livres para optarem entre as duas disciplinas (PE1 e PE3), de acordo com seus interesses sobre os temas propostos em cada uma das disciplinas.

O pré-requisito para a matrícula na disciplina é ter sido aprovado em 15 componentes curriculares (disciplinas). Esta regra fez com que o número de alunos inicialmente interessados na disciplina "Problematizando a Ciência na Mídia" reduzisse consideravelmente. Ao todo, 9 alunos concluíram a disciplina. 
Nossa proposta para PE1 foi a inserção da mídia no ensino de ciências, tema desta tese. O projeto da disciplina foi tributário tanto das leituras que compõem a fundamentação teórica desta tese quanto das experiências na disciplina EDCZ2.

A disciplina foi iniciada com orientações gerais para o estágio, na qual apresentamos as exigências do estágio, os documentos legais que seriam necessários, como carta de apresentação do estagiário (para ser entregue na escola onde estagiará), credenciamento de estágio (na escola onde estagiará), cadastro do estagiário (no IFSP), termo de compromisso (para ser entregue tanto na escola quanto no IFSP) e, por fim, o relatório de estágio. Não existe um modelo pré-definido para o relatório de estágio, cabendo ao Professor orientar os licenciandos sobre o que espera deste relatório. Este foi um dos documentos que compuseram o corpus desta pesquisa, como detalharemos na seção a seguir.

Após a discussão sobre o estágio, começamos a delinear os debates que pretendíamos elaborar com os licenciandos. Assim como em EDCZ2, iniciamos a discussão com uma questão ampla e que consideramos fundamental: "Por que Ensinar Ciências em nossa sociedade atual?". Os argumentos levantados pelos licenciandos giraram em torno de duas questões principais: compreender fenômenos do dia a dia, principalmente relacionados à tecnologia; e desmistificar a ciência e o cientista. Um dos exemplos trazidos durante a aula foram as propagandas de creme dental, na qual, segundo eles, usa-se a figura de autoridade da ciência para vender produtos. Também foi discutido questões éticas envolvendo a produção da ciência. O exemplo mais comentado foi o Projeto Manhattan, que culminou no lançamento das bombas atômicas sobre Hiroshima e Nagasaki. Não houve consenso, contudo, com relação à responsabilização direta dos cientistas sobre as atitudes de guerra.

$\mathrm{Na}$ aula seguinte passamos a uma exposição, cuja intenção foi sintetizar as discussões da aula anterior e apresentar algumas perspectivas 
atuais do ensino de ciências, particularmente através de trabalhos sobre Alfabetização Científica.

A partir das conclusões de que não basta ensinarmos apenas conceitos e teorias científicas, discutimos a importância de ensinarmos sobre a ciência. Com o intuito de defender um ensino de ciências focado nas relações sociais que envolvem a ciência, priorizando as possibilidades de tomada de decisão por parte dos alunos, passamos a discutir características do empreendimento científico, sobretudo através de trabalhos relacionados à Natureza da Ciência. O objetivo de inserir o debate da $\mathrm{NdC}$ nesta disciplina foi o de problematizar a própria prática científica, de modo a desenvolver visões mais críticas sobre seus desenvolvimentos.

Após este ciclo focado na educação científica e em questões epistemológicas da ciência, passamos a discutir o tema principal da disciplina: mídia. Iniciamos esta discussão através de um diálogo sobre o "Relatório Final"31 da Pesquisa Brasileira de Mídia (2016), publicada pela "Secretaria de Comunicação Social” (SECOM) da Presidência da República. A empresa responsável pelo relatório foi a "IBOPE inteligência".

A intenção do diálogo em torno deste documento foi o de compreendermos alguns hábitos de consumo de mídia dos brasileiros. Os dados que os licenciandos chamaram a atenção estão esquematizados abaixo:

- $89 \%$ das pessoas que participaram da pesquisa declaravam que se informavam sobre o que acontece no Brasil através da Televisão.

- $\quad 77 \%$ declaram assistir TV todos os dias da semana.

- $73 \%$ dos entrevistados mencionaram a TV GLOBO quando questionados sobre a emissora que mais assistem.

\footnotetext{
${ }^{31}$ Disponível em: http://www.secom.gov.br/atuacao/pesquisa/lista-de-pesquisas-quantitativas-equalitativas-de-contratos-atuais/pesquisa-brasileira-de-midia-pbm-2016.pdf/view. Último acesso em $17 / 06 / 2019$ às $10 h 51$.
} 
- $67 \%$ dos entrevistados declaram nunca assistirem, ouvirem ou lerem jornais.

- $66 \%$ dos que têm costume de ler jornais o fazem na forma impressa.

- O jornal mais citado pelos entrevistados foi "O Globo", com 11\%, seguido de Folha de SP, com 10\%.

- Confiança nas notícias que circulam nos diferentes meios de comunicação: Os licenciandos chamaram a atenção que a pesquisa indica que as notícias dos jornais escritos são mais credíveis, enquanto as notícias em sites e blogs são as que mais gozam de desconfiança dos entrevistados.

Após o diálogo sobre os hábitos de consumo da mídia dos brasileiros, passamos a discutir a importância de inserir debates sobre a mídia na educação. Apresentamos algumas perspectivas constantes na literatura de "educação para as mídias". Também buscamos aproximações entre a educação para as mídias e a perspectiva freireana. Ao todo, foram três encontros, totalizando 9 aulas de $45 \mathrm{~min}$.

Após este ciclo de aulas focado em fundamentos da educação para as mídias, tivemos um encontro com uma Professora convidada, que nos deu uma aula sobre ideologia e utopia em materiais de difusão científica. Para este encontro, nos foi sugerida a leitura do texto "Science popularization, hegemonic ideology and commerciallized science" (GAVROGLU, 2012), publicado no "Journal of History of Science and Technology" por Kostas Gavroglu. A Professora disponibilizou versão em português, traduzida por ela mesma.

Durante todo este período, principalmente durante os horários destinados ao estágio, conversávamos com os licenciandos sobre suas experiências durante o estágio, buscando conhecer a realidade em que estavam inseridos, quais tipos de assuntos estavam sendo abordados, quem eram seus públicos etc. Neste processo, discutíamos com os licenciandos diferentes possibilidades de inserção da mídia em suas regências. A 
exigência da disciplina era que fizessem pelo menos uma regência dentre as 30h de estágio.

Após a aula com a Professora convidada, propusemos uma atividade usando as reportagens publicadas no contexto das observações do eclipse solar de 1919, ocorridas na Ilha Príncipe (África) e em Sobral - CE (Brasil). Os textos utilizados foram os mesmos que já havíamos trabalhado na disciplina EDCZ2, e que foram analisados no capítulo 4:

- Revolution in Science - Times London

- Einstein on his Theory - Times London

- Lights all askew in the heavens - The New York Times

Após a leitura e discussão dos textos, propusemos uma aula, na qual apresentamos alguns conceitos da teoria da relatividade geral, como o princípio de equivalência e a influência da gravidade na propagação da luz. Além disso, focamos principalmente no contexto social que envolveu as expedições inglesas para testar a teoria de um físico alemão em plena guerra. Além disso, focamos em características da mídia, como a imagem atribuída a Einstein, especialmente no New York Times, e outras questões, como a projeção do público leitor. Uma análise detalhada desses textos está apresentada no capítulo 4 e as traduções dos textos utilizados em aula estão em anexo a esta tese. O objetivo principal da aula, além de problematizar as reportagens históricas publicadas no contexto do eclipse solar de 1919 e apresentar o contexto social que envolveu um importante episódio da validação de uma das principais teorias da física, foi o de apresentar uma possibilidade de inserção de materiais de mídia em uma aula de física.

Importante registrar que enfatizamos repetidas vezes que não se tratava de um modelo a ser seguido. Contudo, o contato com os licenciandos nos mostrou que muitos tinham a necessidade de experienciar uma atividade concreta que contemplasse parte dos fundamentos educacionais que havíamos debatido durante a disciplina. 
Em seguida, preparamos uma aula para que cada licenciando pudesse apresentar sua ideia de regência, na qual tinham que apresentar um tema selecionado, quais tipos de materiais de mídia poderia selecionar, porque escolheu determinado tema e determinados materiais e outras questões que julgassem pertinentes. A ideia é que fosse um momento de uma primeira síntese do que vínhamos discutindo, realizada em propostas concretas dos próprios licenciandos. Foram dois encontros para que fossem apresentadas todas as propostas.

$\mathrm{Na}$ aula seguinte selecionei cinco artigos sobre a descoberta de uma carta de Galileu, até então considerada perdida. A descoberta foi publicada pelos historiadores Michele Camerota, Franco Giudice e Salvatore Ricciardo na revista "The Royal Society publishing" 32 . Esta carta descoberta pelos historiadores trazia indícios de edição do físico italiano em passagens que poderia indispô-lo com a inquisição. A princípio tal descoberta foi publicada na seção de notícias da revista Nature. A partir desta publicação da Nature, vários canais de comunicação repercutiram o caso. Para a análise dos licenciados, selecionamos os seguinte mateiriais:

- Discovery of Galileo's long-lost letter shows he edited his heretical ideas to fool the Inquisition ${ }^{33}$, publicado em 21 de setembro de 2018 na Revista Nature. Apresentamos aos alunos uma tradução para o português, feita pelo proponente da tese. A tradução está em anexo a esta tese.

- Carta 'perdida' mostra que Galileu tentou amenizar texto para enganar a Inquisição ${ }^{34}$, publicado em 25 de setembro de 2018 no portal de notícia da Globo, G1.

- Carta que incriminou Galileu por heresia é encontrada, publicado em 21 de setembro de 2018, no portal da Rede Record, R7. O texto é uma

\footnotetext{
${ }^{32}$ Disponível em: https://royalsocietypublishing.org/doi/full/10.1098/rsnr.2018.0053. Último acesso em $17 / 06 / 2019$ às $17 \mathrm{~h} 02$.

${ }_{33}$ Disponível em: https://www.nature.com/articles/d41586-018-06769-4. Último acesso em 17/06/2019 às $17 \mathrm{~h} 44$.

${ }^{34}$ Disponível em: https://oglobo.globo.com/sociedade/ciencia/carta-perdida-mostra-que-galileutentou-amenizar-texto-para-enganar-inquisicao-23099750. Último acesso em 17/06/2019 às 17h47.
} 
reprodução de reportagem da agência italiana de notícias, ANSA Brasil.

- Encontrada carta que incriminou Galileu por Heresia, publicado em 21 de setembro de 2018 na revista ISTO É. O texto também é uma reprodução da reportagem da ANSA Brasil.

- Manuscrito original de Galileu acaba com mistério de carta controversa, publicado em 26 de setembro de 2018 na revista "Galileu".

Esses materiais, recém publicados à época em que foram inseridos em sala de aula, foram discutidos e analisados à luz do conceito de circulação circular da informação proposto pelo sociólogo francês Pierre Bourdieu. A seleção foi intencional e, primeiramente, foi solicitado que os licenciandos lessem os materiais selecionados. Em geral, houve claramente um entendimento de que os materiais eram homogêneos, destacando, inclusive, as mesmas falas dos historiadores. A conclusão que os licenciandos chegaram foi a de que a reportagem da Nature ditou, de certa maneira, como seria dada ênfase às notícias sobre a descoberta da carta de Galileu pelos historiadores italianos. A análise desses materiais foi divulgada na II Jornada Pierre Bourdieu e o Ensino de Ciências, que ocorreu na Universidade Federal do ABC em 14 de Novembro de $2018^{35}$.

Por fim, antes das apresentações das regências dos licenciandos, discutimos brevemente a inserção da educação para as mídias em currículos brasileiros, particularmente na versão da Base Nacional Comum Curricular (BNCC) aprovada em dezembro de 2017. O objetivo não foi o de discutir a BNCC em si, nem sobre as críticas à ideia de uma base curricular comum, mas a de apresentar algumas das defesas da inserção de aspectos relacionados à educação para as mídias na formação básica das pessoas na BNCC. Esta aula foi fundamentada particularmente no artigo "Educomunicação, paradigma indispensável à renovação curricular no ensino básico no Brasil” (SOARES, 2018), publicado na revista

\footnotetext{
${ }^{35}$ Anais do evento disponível em: http://fep.if.usp.br/ profis/Jornadas/Anais II Jornada_Bourdieu.pdf. Último acesso em 17/06/2019 às 18 h04.
} 
“Comunicação \& Educação” em 2018, por Ismar Soares, já citado nesta tese como um dos precursores da "educomunicação" no Brasil.

A disciplina foi finalizada com seminários ministrados pelos licenciandos, cujo objetivo principal foi compartilhar, principalmente, o percurso entre preparação, desenvolvimento e avaliação das regências. Propusemos os seguintes pontos para serem, necessariamente, abordados durante o seminário:

1. Escola onde desenvolveu o estágio. Apresentar algumas observações gerais e/ou pontuais durante as observações: houve algum episódio que lhe chamou a atenção? As observações influenciaram sua aula ou seu planejamento de aula?

2. Tema da Regência. Por que escolheu este tema?

3. Materiais midiáticos selecionados. Mostrar as principais características dos materiais, isto é, a análise feita do material: características relacionadas à ciência, aos conteúdos abordados; características dos materiais midiáticos (isto é, características de linguagem, público alvo, circulação, etc.)

4. Como os materiais selecionados entraram em seu plano de aula?

5. Descrição e avaliação da Regência.

Foram gravados os áudios das apresentações dos licenciandos, com prévio consentimento. Além dos relatórios, esses áudios também compõem o corpus desta tese, como será detalhado na próxima seção.

\subsection{Corpus}

\subsubsection{Materiais de análise da disciplina EDCZ2}

Como dissemos na descrição da disciplina EDC, os materiais que compõem o corpus desta pesquisa estão relacionados aos trabalhos finais 
apresentados pelos alunos: versões em vídeo e texto. Ao todo, 19 licenciandos, distribuídos em cinco grupos apresentaram seus trabalhos.

Para identificar os materiais, usaremos a primeira letra como um indicativo se o trecho selecionado é proveniente de vídeo ou texto, usando respectivamente as letras $\mathrm{V}$ e $\mathrm{T}$. Além disso, usaremos a sigla da disciplina: EDC. Por último, usaremos números de 1 a 5 para identificar cada um dos grupos. Por exemplo: VEDC2 identifica um trecho selecionado do vídeo da apresentação do grupo 2 da disciplina EDC. TEDC3 identifica trecho selecionado de texto do grupo 3 da disciplina EDC.

Abaixo organizamos cada grupo por seus temas:

\begin{tabular}{|c|c|}
\hline Grupo & Tema \\
\hline EDC1 & Acidentes nucleares \\
\hline EDC2 & Vida em Lua de Júpiter \\
\hline EDC3 & Ondas Gravitacionais \\
\hline EDC4 & Ondas Gravitacionais \\
\hline EDC5 & Aquecimento Goblal: o caso \\
& Climategate \\
\hline
\end{tabular}

\subsubsection{Materiais de Análise da disciplina Problematizando a Ciência na Mídia (PE1)}

Assim como em EDC, foram selecionados materiais provenientes tanto da gravação de seminários quanto de textos entregues pelos licenciandos. Contudo, a produção nesta disciplina foi individual, sobretudo por contar com estágio supervisionado. Ao todo, nove alunos fizeram a disciplina até o fim. 
De maneira análoga à organização dos materiais de EDC, usaremos a primeira letra como indicativo de trecho de vídeo ou texto, usando as letras $\mathrm{V}$ e T respectivamente. Complementaremos com a sigla da disciplina (PE) e, por último, enumeraremos cada aluno de 1 a 9 .

Abaixo organizamos cada aluno pelo tema de suas regências.

\begin{tabular}{|c|c|}
\hline Licenciando & Tema da regência \\
\hline PE1 & Acelerador de Partículas Sirius \\
\hline PE2 & Relatividade \\
\hline PE3 & "Gato de Luz" \\
\hline PE4 & Choque térmico e bioenergética \\
\hline PE5 & Desastres naturais envolvendo vulcões \\
\hline PE6 & Atrito e camisinhas autolubrificantes \\
\hline PE7 & Entropia na culinária \\
\hline PE8 & A física nas transmissões esportivas \\
\hline PE9 & Calor \\
\hline
\end{tabular}

\subsection{Referencial metodológico da Análise textual discursiva}

A análise dos materiais selecionados se dará fundamentalmente em uma perspectiva qualitativa, a partir do referencial metodológico da análise textual discursiva, proposta por Moraes (2003). Em primeiro lugar, vale salientar que toda análise, de acordo com o autor, concretiza-se a partir de um conjunto de documentos denominado corpus, que será apresentado adiante. Moraes defende que a análise textual qualitativa pode ser 
compreendida como um processo auto-organizado de construção de compreensão em que novos entendimentos emergem de uma sequência recursiva de três elementos: "desconstrução dos textos do corpus, a unitarização; estabelecimento de relações entre os elementos unitários, a categorização; o captar do novo emergente em que a nova compreensão é comunicada e validada" (MORAES, 2003, p. 192).

Uma das características centrais da análise textual discursiva, a nossa ver, é a consideração de que os textos que compõem o corpus da pesquisa não são produções estáticas que carregam um significado a ser apenas identificado. Pelo contrário, são significantes que exigem que o leitor ou o pesquisador construa significados com base em suas teorias e pontos de vista. Entendemos isto como uma defesa de que o significado de um texto não se dá apenas na elaboração do autor, mas na relação que se dá entre o que foi produzido pelo autor e o que foi apreendido/interpretado pelo leitor/interlocutor. Isso exige que o pesquisador se assuma como autor das interpretações que constrói dos textos que analisa. Estas considerações denotam a aproximação das perspectivas da análise de conteúdo e da análise do discurso na proposta de Moraes (2003). Como afirmam Moraes e Galiazzi (2006, p. 118), “a análise textual discursiva é uma abordagem de análise de dados que transita entre duas formas consagradas de análise na pesquisa qualitativa que são a análise de conteúdo e a análise de discurso".

A seguir apresentaremos a sequência recursiva proposta pelo autor: unitarização, categorização e captação do novo emergente.

\subsubsection{Desmontagem dos textos: desconstrução e unitarização}

O primeiro passo da análise, como proposto pelo autor, é o que ele chama de "desmontagem do texto". Significa colocar o foco nos detalhes e nas partes componentes do texto, um processo de divisão que segundo o autor toda análise implica. Dessa desconstrução surgem as unidades de análise. É fundamental que seja reconhecido pelo pesquisador em quais contextos e quais documentos deram origem a cada unidade de análise. Para 
isso, usa-se códigos que indicam a origem de cada unidade. O autor exemplifica, como procedimento possível, atribuir inicialmente um número ou letra a cada documento do corpus e um segundo número ou letra a cada uma das unidades de análise.

A definição dessas unidades de análise pode partir tanto de categorias definidas a priori, como de categorias emergentes. O autor defende a necessidade de um intenso contato e impregnação com o material de análise, e entende que essa impregnação passa por um processo de desorganização e desconstrução, para que possam surgir novas compreensões. O autor toma como referência as ideias dos sistemas complexos que consistem, segundo ele, em levar o sistema semântico ao limite do caos. Assim, afirma que o processo de unitarização

[...] produz desordem a partir de um conjunto de textos ordenados.

Torna caótico o que era ordenado. Nesse espaço uma nova ordem pode constituir-se às custas da desordem. $\mathrm{O}$ estabelecimento de novas relações entre os elementos unitários de base possibilita a construção de uma nova ordem, representando uma nova compreensão em relação aos fenômenos investigados. (MORAES, 2003, p. 196)

Portanto, o processo de desconstrução visa identificar elementos que constituem unidades de significado que compõem o texto, levando o sistema ao "limite do caos". A partir dessa unitarização criam-se possibilidades de emergência de interpretações criativas, que estarão relacionadas ao escopo teórico que guia todo o processo. Parte fundamental para tais interpretações é categorizar as unidades de análise, sejam por categorias a priori ou categorias emergentes do próprio corpus, ou, ainda, um misto entre as duas possibilidades. Isto é, categorias que surgem a priori, mas que vão sendo modificadas a partir da "impregnação" com o corpus da pesquisa e, especialmente, com as unidades de análise.

\subsubsection{Categorização}

O segundo momento do ciclo de análise é a categorização, cujo objetivo central é o agrupamento de elementos semelhantes. O autor afirma que no 
processo de categorização podem ser construídos diferentes níveis de categorias. Pode-se partir de diferentes metodologias para a construção de categorias. Moraes destaca os métodos indutivo e dedutivo. $\mathrm{O}$ método dedutivo seria o movimento do geral para o particular, que implica construir categorias antes mesmo de examinar o corpus de textos, a partir das teorias que servem de fundamento para a pesquisa. Isto é, são categorias a priori. Por outro lado, o método indutivo constrói as categorias a partir das informações contidas no corpus de texto. É um caminho do particular para o geral, que resulta em categorias emergentes. Há ainda a possibilidade de combinar esses dois métodos, indutivo e dedutivo. Partindo de categorias definidas a priori com base em teorias previamente estabelecidas, "o pesquisador encaminha transformações gradativas no conjunto inicial de categorias, a partir do exame das informações do corpus de análise" (MORAES, 2003, p. 197). O autor apresenta também o método que ele chama de intuitivo, que pretende superar a "racionalidade linear que está implícita tanto no método dedutivo quanto no indutivo" (idem).

Existem algumas propriedades que as categorias devem ter. Uma delas está relacionada à validade ou pertinência das categorias, isto é, devem ser válidas e pertinentes em relação aos objetivos e ao objeto de análise. Outra propriedade das categorias que o autor julga necessária, independente de seu método de produção, é a homogeneidade: "Não se pode misturar plantas e animais quando categorizando plantas" (MORAES, 2003, p. 199). Contudo, continua o autor, "é claro que é possível construir dois conjuntos de categorias complementares em que cada um deles tem um princípio classificatório diferente" (idem). Neste ponto, vale o parêntese com relação à categorização que empreendemos nesta pesquisa. Construímos três grupos de categorias de análise de nosso corpus: um grupo focado na análise da ciência, um focado na mídia e outro em processos de ensino. Esses grupos de categorias foram construídos a partir de teorias diferentes apresentadas nesta tese, e pretendem ser complementares na busca por compreender os fenômenos estudados que envolvem ciência, mídia e ensino. As categorias iniciais foram modificadas ao longo do processo de 
impregnação com o corpus. Partimos de categorias gerais e, a partir do contato com o material de análise, foram criadas categorias mais específicas.

Moraes antagoniza-se ao que chama "análises de conteúdo tradicionais" que exigem, segundo ele, que as categorias sigam um critério de exclusão mútua. Isto é, a exigência de que um mesmo dado seja categorizado apenas em uma categoria.

Uma mesma unidade pode ser lida de diferentes perspectivas, resultando em múltiplos sentidos, dependendo do foco ou da perspectiva em que seja examinada. Por essa razão, aceitamos que uma mesma unidade possa ser classificada em mais de uma categoria, ainda que com sentidos diferentes. Isso representa um movimento positivo no sentido da superação da fragmentação, em direção a descrições e compreensões mais holísticas e globalizadas. (MORAES, 2003, p. 199)

A superação do critério de exclusão mútua, segundo o autor, é uma busca por superar o "reducionismo marcante em formas históricas de análise do conteúdo" (MORAES, 2003, p.199). A ideia do autor é que as categorias sejam maneiras de focalizar o todo por meio das partes.

Se em um primeiro momento (unitarização) a ideia é fragmentar, desconstruir, isolar unidades de significado, na categorização, segundo momento da análise, busca-se "estabelecer relações, reunir semelhantes, construir categorias" (MORAES, 2003, p. 201). O objetivo desta etapa é produzir uma nova ordem para os materiais de análise, uma nova síntese. Não se pretende retornar aos textos originais, mas construir um novo texto, construir "um metatexto que tem sua origem nos textos originais, expressando um olhar do pesquisador sobre os significados e sentidos percebidos nesses textos" (idem, grifo nosso).

Portanto, a etapa de categorização visa à construção de uma síntese analítica expressa em um metatexto, que constitui um conjunto de argumentos descritivos-interpretativos, a partir do corpus de análise, que expressam a compreensão do pesquisador em relação ao fenômeno estudado. $\mathrm{O}$ autor, de maneira poética, cria a seguinte metáfora para o processo que 
vai da desordem da unitarização à organização da categorização implicando em emergência de interpretações no metatexto produzido:

A partir das gotículas de água e de suas cargas elétricas formando o mundo desordenado e caótico das nuvens de uma tempestade, podem emergir os raios de luz a iluminar todo o cenário. (MORAES, 2003, p. 202)

\subsubsection{Captando o novo emergente: a construção de metatextos}

O autor apresenta a análise textual qualitativa como uma metodologia que, de maneira geral, constrói metatextos, a partir de um conjunto de textos ou documentos, que descrevem e interpretam sentidos e significados que o analista constrói a partir do referido corpus: "todo o processo de análise proposto volta-se à produção do referido metatexto" (MORAES, 2003, p. 202). No momento da produção do metatexto o desafio, de acordo com o autor, é conseguir construir "argumentos centralizadores" ou "teses parciais" para cada uma das categorias, ao mesmo tempo em que exercita a elaboração de um "argumento central” ou "tese” para sua análise como um todo. No nosso entendimento, a ideia de construção do metatexto é exatamente a busca por compreender os pormenores das produções analisadas para que se busque uma articulação entre as compreensões permitidas por cada categoria, com o intuito de compreender/interpretar o fenômeno estudado de maneira mais ampla.

Esse terceiro estágio da análise textual qualitativa é a comunicação das novas compreensões atingidas ao longo dos dois estágios anteriores. A construção do metatexto é um processo reiterativo de reconstrução, no qual é "essencial a construção de um texto em que cada uma de suas categorias ou partes sejam perfeitamente integradas num todo"(MORAES, 2003, p.208), o que exige, continua o autor, "que haja uma tese ou argumento central, capaz de possibilitar o encadeamento das partes no todo". 
No próximo capítulo apresentaremos a análise das produções dos licenciandos. As análises estão divididas em duas seções: uma destinada à análise dos materiais produzidos na disciplina EDC e outra seção com a análise dos materiais produzidos em PE1. As análises foram organizadas de acordo com os três eixos propostos no capítulo 5 . 


\section{Capítulo 7}

\section{Análise das Produções dos Licenciandos em Física}

O objetivo central desta tese é defender a inserção da mídia em aulas de física, de modo que tanto os processos de produção midiática como o próprio conhecimento científico e suas relações com a sociedade sejam problematizados. Para tal, é fundamental buscar essa aproximação na formação inicial de professores. Assim, propusemos duas disciplinas que foram ministradas a professores de física em formação, que foram apresentadas em detalhes no capítulo anterior. Neste capítulo, nossa intenção será a de analisar as produções desses licenciandos, buscando compreensões acerca de como eles propuseram aproximações entre as perspectivas da educação para as mídias e o ensino de física através de propostas concretas, a partir de análises de materiais midiáticos sobre ciências, proposições de planos de aula envolvendo esses materiais e regências ministradas em estágios supervisionados. Nossa intenção é analisar, principalmente, as potencialidades e limitações presentes nessas produções e quais foram as tensões envolvidas na busca por inserir a mídia no ensino de física nas práticas de ensino desenvolvidas pelos professores em formação. Apresentaremos a análise dos materiais de cada uma das disciplinas separadamente, principalmente por entender que ambas têm características particulares, sobretudo porque uma envolve estágio supervisionado e, portanto, a proposição de regências, enquanto a outra configura-se como uma primeira aproximação dos licenciandos com discussões de ensino. 


\subsection{Produções dos licenciandos da disciplina "Introdução ao Ensino e à Divulgação da Ciência"}

Com o objetivo de contextualizar as análises, apresentaremos, inicialmente, uma descrição dos trabalhos desenvolvidos por cada um dos cinco grupos. Apresentaremos os materiais midiáticos selecionados pelos licenciandos, identificando cada meio de comunicação e os pontos principais dessas produções. Faremos apenas uma apresentação descritiva de tais materiais, visto que não é intenção desta tese analisar essas produções midiáticas, senão as produções que os licenciandos fizeram a partir desses materiais, que serão analisadas na seção 7.2.

\subsubsection{Materiais midiáticos selecionados pelos grupos de EDC}

O grupo 1 selecionou dois textos sobre diferentes episódios envolvendo acidentes nucleares, ambos publicados no site da BBC Brasil. Um deles publicado em 15 de março de 2011 intitulado Entenda o vazamento radioativo em Fukushima e os riscos para saúde ${ }^{36}$. O segundo texto foi publicado em 8 de agosto de 2015 intitulado Por que Hiroshima e Nagasaki são habitáveis e Chernobyl não?37

A reportagem de 2011 foi publicada logo após a terceira explosão de um dos reatores da usina nuclear de Fukushima, no Japão. A reportagem chama atenção que, após este ocorrido, as autoridades japonesas alertaram que a radiação vazada da usina aproximava-se de níveis preocupantes. A reportagem é iniciada com uma foto na qual cidadãs japonesas têm o nível de radiação checada por meio de um aparelho manuseado por um homem de jaleco branco, escoltado por um militar vestindo uma máscara com filtros. A reportagem aborda assuntos como a escala do vazamento radioativo, afirmando que moradores que vivem em um raio de $30 \mathrm{~km}$ da usina foram aconselhados a deixarem suas residências ou permanecerem em casa de

\footnotetext{
${ }^{36}$ Disponível em: https://www.bbc.com/portuguese/noticias/2011/03/110315 japao qa pu. Último acesso em 18/06/2019 às $19 \mathrm{~h} 29$.

${ }^{37}$ Disponivel em:

https://www.bbc.com/portuguese/noticias/2015/08/150808 hiroshima nagasaki chernobil rm. Último acesso em 18/06/2019 às $19 h 30$.
} 
portas fechadas para evitar exposição. Além disso, abordaram a composição dos principais materiais radioativos vazados: isótopos de césio, iodo, nitrogênio e argônio. Enfatizam que não há indícios, segundo os especialistas, de vazamento de plutônio e urânio. A reportagem apresenta os principais riscos para a saúde humana devido à exposição a essas radiações. A exposição em baixos níveis, de acordo com a reportagem, pode provocar náusea, vômito, diarreia, dor de cabeça e febre. Em altos níveis, essa exposição pode incluir também danos possivelmente fatais aos órgãos internos do corpo. No longo prazo, o maior risco do iodo radioativo é o câncer, e as crianças são potencialmente mais vulneráveis. Para exemplificar o risco do câncer pela exposição à radiação, a reportagem usa o caso de Chernobyl, ocorrido em 1986, que segundo a reportagem resultou em um aumento de casos de câncer de tireóide (região em que o iodo radioativo absorvido pelo corpo tende a se concentrar) na população infantil da vizinhança da usina.

Por fim, discutem como se deu o vazamento do material radioativo, indicando o superaquecimento do reator, devido a problemas com o sistema de resfriamento, como principal causa. Concluem, embasados nos posicionamentos de especialistas, que seria pouco provável que o vazamento em Fukushima chegasse às proporções de Chernobyl e que não haveria riscos de explosões nucleares, já que bombas nucleares e reatores nucleares são coisas diferentes.

A reportagem de 2015, Por que Hiroshima e Nagasaki são habitáveis e Chernobyl não?, também é iniciada com uma imagem, representando uma zona de exclusão em Chernobyl que ninguém pode cruzar, na qual podemos ver um grande portão de metal sendo fechado por um militar. A reportagem é iniciada com a retomada de dados sobre os impactos das bombas atômicas lançadas sobre Hiroshima e Nagasaki em 1945. Enfatizam dados como: dos cerca de 350 mil habitantes em Hiroshima, 80 mil foram mortos pelo lançamento da bomba; há uma estimativa de que o número final de mortes, considerando as decorrências das feridas sofridas e dos efeitos da radiação, varie entre 90 mil e 166 mil pessoas; 80\% dos edifícios foram destruídos ou 
sofreram danos irreparáveis; Em Nagasaki, estima-se, de acordo com a reportagem, que de uma população de aproximadamente 263 mil pessoas, morreram entre 39 mil e 80 mil pessoas menos de um segundo após a bomba explodir.

Após apresentarem esses dados acerca das bombas lançadas pelos Estados Unidos da América sobre o Japão durante a segunda guerra mundial, a reportagem passa a falar do que classificaram como o pior desastre nuclear da história, em que um dos quatro reatores de Chernobyl, na Ucrânia (parte da então URSS), explodiu e causou um incêndio que liberou enormes quantias de partículas radioativas na atmosfera. A reportagem afirma que 31 pessoas morreram em decorrência direta do acidente, embora investigações sobre os efeitos em longo prazo, como o câncer, ainda continuam sendo feitas.

O âmago da reportagem está na comparação entre os dois episódios históricos: as bombas atômicas e o acidente na Ucrânia. A pergunta central levantada é a seguinte: Como foi possível, então, que Hiroshima e Nagasaki, que sofreram explosões nucleares tão devastadoras e com tantas vítimas fatais, se tornassem cidades prósperas e habitáveis, enquanto Chernobyl virou um lugar completamente inabitado e assim seguirá por muitos anos? A reportagem aponta três pontos principais para responder a esta pergunta: Quantidade de combustível nuclear; Diferenças nas reações nucleares; Localização; Com relação à quantidade de combustível nuclear liberado, a reportagem afirma que Chernobyl emitiu 100 vezes mais radiação que as bombas que caíram sobre Hiroshima e Nagasaki. Com relação às reações, a reportagem afirma que as bombas foram submetidas a fissões nucleares usando Urânio, em Hiroshima, e plutônio, em Nagasaki. Por sua vez, o acidente em Chernobyl fez com que o combustível nuclear se fundisse, liberando isótopos radioativos que incluíam xenônio, iodo radioativo e césio. Com relação à localização, enfatizam que as bombas foram detonadas no ar, fazendo com que os depósitos radioativos se dispersassem como efeito da nuvem criada pela explosão. Já em Chernobyl, o reator 4 se fundiu na 
superfície, produzindo uma ativação de nêutrons que fizeram com que a terra se tornasse radioativa.

O grupo 2 selecionou o tema "vida extraterrestre", mais especificamente sobre a possibilidade de vida nas luas de Júpiter. O grupo selecionou um texto da Revista Galileu intitulado Astrônomos estudam quais formas de vida podem existir em lua de Júpiter ${ }^{38}$, publicado em 27 de fevereiro de 2018. Selecionaram, também, um texto da BBC Brasil intitulado Nasa anuncia missão para lua de Júpiter que pode ter vida39, publicado em 5 de março de 2014. Além disso, apontam uma matéria publicada no site da Globo no qual reproduzem ipsis literis a produção da BBC mencionada acima.

O texto assinado pela redação da Galileu é iniciado com uma foto atribuída à NASA e às Universidades do Arizona e do Colorado. A foto leva a legenda: “Sardas rosadas' características da Europa, Lua de Júpiter”. A matéria indica que a depender da NASA, a Lua de Júpiter, Europa, será o principal destino de exploração espacial em 2030. Este interesse na Europa viria, de acordo com o texto, por ela ser coberta por uma camada de 10 quilômetros de gelo que escondem outros 100 quilômetros de água aquecida pela energia térmica produzida pela interação gravitacional com o gigantesco planeta Júpiter. Assim, Europa seria um objeto propício para o desenvolvimento de vida. A matéria apoia esta última afirmação em estudo publicado no periódico Scientific Reports.

Após contextualizarem a relevância da exploração da Europa, a matéria destaca uma pesquisa que simula o que pode ser encontrado no satélite de Júpiter. Particularmente, destacam estudo desenvolvido por pesquisadores da Universidade de São Paulo, cujo objetivo principal foi o de analisar dados de uma bactéria que vive em uma mina de ouro de Mponeng, na África do Sul. A bactéria a qual é feito menção é a Candidatus

\footnotetext{
${ }^{38}$ Disponível em: https://revistagalileu.globo.com/Ciencia/noticia/2018/02/astronomos-estudam-quaisformas-de-vida-podem-existir-em-lua-de-jupiter.html. Último acesso em 19/06/2019 às 10h48.

${ }^{39}$ Disponível em:

https://www.bbc.com/portuguese/noticias/2014/03/140305 jupiter lua missao nasa fn. Último acesso em 19/06/2019 às 10h51.
} 
Desulforudis audaxviator, uma espécie que vive sem luz solar e através de reação radioativas da água, condições que podem ser semelhantes às da Europa, afirma a matéria. $\mathrm{Na}$ sequência, destacam uma entrevista de Douglas Galante, pesquisador da USP, concedida à Revista FAPESP. Destacam a fala de Galante em que o cientista indica que a bactéria extremófila estudada utiliza os sulfatos produzidos pela reação entre radicais livres e compostos de rochas, principalmente a pirita, para sintetizar ATP, condição para o armazenamento de energia nas células. A matéria é concluída indicando que saber se há pirita no satélite Europa seria uma das questões em aberto que precisam ser desvendadas por missões espaciais futuras.

A reportagem da BBC, publicada em 2014, também é iniciada com uma imagem da Lua Europa. E, assim como a matéria da Galileu, indica que os cientistas apontam a Lua Europa como sendo um local propenso à vida extraterrestre. Contudo, o enfoque principal da reportagem da BBC são os planos da NASA de enviar uma missão não tripulada à lua de Júpiter. Afirmam que a NASA já teria separado, no momento da publicação da matéria, 15 milhões de dólares em sua proposta de orçamento para 2015 para iniciar o projeto, que previa lançamento somente após 2020. A reportagem é publicada tendo como contexto o anúncio da missão feito por Charles Bolden, então administrador da NASA. A reportagem enfatiza que não foram publicados detalhes da missão à Europa, mas Elizabeth Robinson, então chefe do setor financeiro da agência espacial americana, teria confirmado que a missão só seria iniciada na década de 2020. A reportagem é concluída afirmando que algumas expedições já passaram perto de Europa, como a sonda Galileu, em 1889, que tinha como objetivo estudar o planeta Júpiter, mas que nenhuma se concentrou especificamente nas dezenas de luas deste planeta, o que deve ser feito agora, já que os cientistas indicam a Europa como sendo um ambiente propenso à vida, sobretudo após descobertos jatos de água expelidos através do gelo que cobre a lua. 
O grupo 3 selecionou o tema "ondas gravitacionais", que ganhou a mídia principalmente no ano de 2016, quando foram publicadas evidências de que havia-se detectado sua existência. O grupo selecionou o texto Cientistas detectam ondas gravitacionais no Universo ${ }^{40}$ publicado na Folha de SP em 12 de fevereiro de 2016. O artigo faz parte da coluna assinada por Salvador Nogueira. Selecionaram, também, o texto $A$ colisão de buracos negros gera ondas de gravidade. Porque isso importa ${ }^{41}$ publicado na revista ÉPOCA em 11 de fevereiro de 2016 e assinado por Rafael Ciscati.

A reportagem da Folha, assinada por Salvador Nogueira, começa afirmando que físicos americanos anunciaram com "estardalhaço" a "primeira detecção irrefutável de ondas gravitacionais", fenômeno previsto por Einstein há cem anos e que ainda não havia sido confirmado. A partir da indicação do anúncio da descoberta, Nogueira passa a explicar o fenômeno em si. Em primeiro lugar, usa a metáfora do espaço como a superfície de um lago, no qual emana uma série de ondas a partir do ponto onde jogamos uma pedra. A pedra usada na analogia é associada à colisão entre dois buracos negros, cada um com massa cerca de 30 vezes a massa do Sol e a mais de 1 bilhão de anos luz de distância, de acordo com a reportagem. Apresentam uma imagem atribuída à Caltech, MIT, LIGO laboratory representando o "balé da morte" executado por dois buracos negros que geraram as ondas gravitacionais que foram detectadas. Nogueira estima a grandeza da colisão entre os dois buracos negros afirmando que o evento, por uma fração de segundo, produziu mais energia do que todas as estrelas do Universo. Contudo, voltando à analogia inicial, afirma que para nós, na beira do lago e muito longe do centro da ação, tudo se resumiu a uma pequena série de tremulações no espaço, detectáveis por dois sistemas de laser gêmeos, que compunham o aparato experimental usado pelo LIGO (Observatório de Ondas Gravitacionais por Interferômetro de Laser), que foi apresentado nos parágrafos seguintes.

\footnotetext{
${ }^{40}$ Disponível em: https://www1.folha.uol.com.br/ciencia/2016/02/1738847-cientistas-detectam-ondasgravitacionais-no-universo.shtml. Último acesso em 19/06/2019 às $14 \mathrm{h01.}$

${ }_{41}^{41}$ Disponível em: https://epoca.globo.com/vida/noticia/2016/02/colisao-de-buracos-negros-geraondas-de-gravidade-por-que-isso-importa.html. Último acesso em 19/06/2019 às 14 h04.
} 
Em seguida, a matéria de Salvador Nogueira apresenta um aplicativo desenvolvido pela "FOLHA gráficos", no qual representam o universo como uma malha espacial "maleável". O aplicativo apresenta algumas imagens, como a Terra orbitando o Sol, acompanhadas de pequenos textos, tais como uma breve explicação da teoria da relatividade. A matéria indica que a expectativa é que novos estudos sobre o universo devem ocorrer, já que antes estávamos limitados a cosmos que podíamos ver. Agora, afirma Nogueira, podemos também ouvi-lo, referindo-se à conversão de ondas gravitacionais para ondas sonoras, feita pelos cientistas envolvidos na detecção anunciada.

Por fim, Nogueira ressalta a frase de David Reitze, na qual o cientista afirmou: "Nós detectamos ondas gravitacionais". Este "nós" inclui grupos brasileiros da UNESP e INPE, afirma o colunista da Folha. Esta frase ganha ainda mais destaque, segundo Nogueira, se consideramos que por pelo menos três vezes a detecção de ondas gravitacionais tinham sido equivocadamente publicadas.

A matéria publicada na revista Época e assinada por Rafael Ciscati é iniciada com uma imagem que representa a colisão entre dois buracos negros. Ciscati inicia seu texto indicando a descoberta das ondas gravitacionais pelo LIGO. Afirma que as ondas em questão foram criadas pelo choque entre dois buracos negros, ocorrido há cerca de 1,3 bilhão de anos. $\mathrm{O}$ autor retoma parte da história da proposição da existência de ondas gravitacionais, afirmando que tal previsão havia sido feita por Einstein em 1915 em sua Teoria da Relatividade Geral. Passa a explicar como funciona a gravidade de acordo com a teoria einsteiniana, enfatizando, particularmente, que corpos em movimento geram distorções no espaçotempo. Além de colocar a detecção das ondas gravitacionais como uma confirmação da Teoria da Relatividade Geral, o autor afirma que os resultados do LIGO também confirmam a existência dos buracos negros, que até então só contava com evidências indiretas. 
Em seguida, Ciscati passa a explicar o que são as ondas gravitacionais. Apela, em primeiro lugar, para o recurso analógico. Faz a famosa analogia de uma bola de boliche sobre um colchão (uma das possíveis variações da analogia que usa um objeto qualquer sobre uma superfície elástica qualquer para explicar a deformação do espaço-tempo). Quando coloca-se uma bolinha de gude próximo à bola de boliche sobre o colchão, o resultado é a "atração" entre os dois corpos, afirma Ciscati. É assim que ele faz a analogia para o funcionamento da gravidade na teoria da relatividade. Faz algumas comparações entre a gravitação newtoniana e einsteiniana, sobretudo no que diz respeito à ação à distância e à velocidade de propagação da gravidade.

O autor afirma que há meses havia "fofocas" entre os cientistas sobre a deteç̧ão das ondas gravitacionais. Contudo, os membros da equipe se mantiveram cautelosos, pois um anúncio equivocado "pegaria mal", de acordo com Cistati, particularmente porque em 2014 um grupo de astrônomos já havia anunciado a detecção de ondas gravitacionais, que acabaram sendo atribuídas à "mera interferência gerada por poeira cósmica”. O autor levanta a pergunta sobre porque teria se passado tanto tempo, cerca de um século, entre a previsão das ondas gravitacionais e sua detecção. A principal resposta é que as ondas gravitacionais são "sutis", o que gera um desafio técnico enorme para sua detecção, que deve ter a precisão em medidas de posição da ordem de mil vezes menor que o diâmetro de um próton. Por fim, Cistati elenca algumas razões pelas quais se pode afirmar que a detecção anunciada era importante, tais como a confirmação da teoria da relatividade, da existência de buracos negros, por carregarem características dos locais onde foram geradas e por abrirem novas possibilidades de investigações sobre o cosmos.

O grupo 4 também selecionou o tema das ondas gravitacionais. $\mathrm{O}$ grupo selecionou dois textos: Einstein (mais uma vez) está certo: ondas 
gravitacionais têm nova deteç̧ão anunciada na Itália ${ }^{42}$, publicado na $\mathrm{BBC}$ Brasil em 29 de setembro de 2017; Previstas por Einstein, ondas gravitacionais rendem o Nobel de Física a três cientistas ${ }^{43}$, publicado no jornal O Globo em 3 de outubro de 2017.

A reportagem da BBC, Einstein (mais uma vez) está certo, é iniciada com uma imagem multicolorida representando a colisão entre dois buracos negros. A legenda diz que as ondas gravitacionais foram provenientes de dois buracos negros, a 1,8 bilhão de anos-luz da Terra. A primeira afirmação do texto é que Einstein estava certo de que existiam ondas gravitacionais. Enfatizam que o termo em si, "ondas gravitacionais", foi cunhado pelo físico alemão. O texto afirma que as ondas gravitacionais foram uma das bases da teoria geral da relatividade, "uma das postulações mais revolucionárias da história da Ciência". A reportagem diz respeito ao anúncio do Observatório Europeu de Gravidade (EGO). O texto afirma que anunciaram "a detecção de ondas com massa cerca de 53 vezes maior que o Sol". Supomos que o anúncio se referia a ondas gravitacionais geradas por buracos negros com massa cerca de 53 vezes maior que a massa solar. A reportagem destaca afirmações de Sheila Rowan, astrofísica da Universidade de Glasgow, à própria $\mathrm{BBC}$, dentre elas que tais detecçoes fazem parte pela busca de compreensões sobre a formação e evolução de buracos negros. Por fim, a reportagem da BBC explica aos leitores o que são ondas gravitacionais, usando a analogia de uma pedra atirada em um rio.

A reportagem do jornal $\mathrm{O}$ Globo é iniciada com uma foto de Kip Thorne, um dos físicos laureados com o prêmio Nobel graças à deteç̧ão das ondas gravitacionais. A primeira afirmação do texto é que a existência das ondas gravitacionais foi prevista por Albert Einstein, com base em sua teoria da relatividade e que só após um século o fenômeno foi comprovado. Essa "façanha", afirma O Globo, rendeu o prêmio Nobel de Física ao alemão

\footnotetext{
${ }^{42}$ Disponível em: https://www.bbc.com/portuguese/geral-41428372. Último acesso em 24/06/2019 às 09 h49.

${ }^{43}$ Disponível em: https://oglobo.globo.com/sociedade/ciencia/previstas-por-einstein-ondasgravitacionais-rendem-nobel-de-fisica-tres-cientistas-21901272. Último acesso em 24/06/2019 às $09 h 52$.
} 
Rainer Weiss e aos americanos Berry Barish e Kip Thorne. A reportagem afirma que o prêmio foi dado a eles porque esses cientistas "pavimentaram o caminho" para a construção do observatório de ondas gravitacionais por interferometria laser, que detectou a colisão de dois buracos negros há 1,3 bilhão de anos. O texto também dispõe da analogia da perturbação de um objeto sobre uma superfície de água.

O texto de O Globo apresenta a fala de alguns cientistas sobre a detecção das ondas e sobre o prêmio Nobel dado aos três cientistas. Uma delas a de Goran Hansson, secretário geral da Academia de Ciência, que teria afirmado que a detecção desse fenômeno "sacudiu o mundo", e o trio foi laureado pela "sua contribuição decisiva para o detector LIGO e a observação das ondas gravitacionais".

Em seguida, a reportagem retoma alguns episódios históricos. Começa afirmando que o próprio Einstein não estava convencido da possibilidade de detecção das ondas gravitacionais quando as propôs teoricamente, e tinha dúvidas se essas ondas eram reais ou apenas "ilusões matemáticas". A matéria afirma, ainda, que Arthur Eddington, astrônomo inglês e amigo de Einstein, era ainda mais cético. De acordo com a reportagem, a existência das ondas gravitacionais só passou a ser aceita no fim da década de 1950. A primeira evidência indireta dessas ondas surgiu em 1970, em particular por estudos da emissão de energia por estrelas binárias. Desde então, continua a reportagem, cientistas em várias partes do mundo dedicaram estudos para a detecção do fenômeno. Neste contexto apontam os experimentos do LIGO. Apresentam dados que envolveram o fenômeno, como as massas dos buracos negros, da ordem de 36 vezes a massa solar um e 29 massas solares o outro, que colidiram a uma velocidade equivalente à metade da velocidade da luz em uma galáxia distante, há estimados 1,3 bilhão de ano. Por se tratar de um fenômeno ocorrido há tanto tempo e muito distante espacialmente, os efeitos da passagem das ondas gravitacionais na Terra seriam ínfimos, o que gerou grande desafio do ponto de vista experimental. Passam, então, a explicar como funcionou o experimento do LIGO, no qual foi usado um 
interferômetro "em L". A reportagem atribui à Kip Thorne as análises sofisticadas e teorias avançadas para a construção do mais "sensível instrumento jamais construído”. À Weiss foram atribuídos altos níveis de engenharia criativa para que o laboratório pudesse ser isolado de vibrações , efeitos térmicos etc. E à Barish atribuíram a ampliação do laboratório, que passou de um projeto de pequena escala com 40 funcionários para um projeto internacional com mais de 1000 participantes. A reportagem é concluída com o seguinte posicionamento: "Mas é claro que o sucesso do LIGO se deve literalmente a centenas de cientistas e engenheiros dedicados. O fato de o comitê do Nobel se recurar [sic] a conceder o prêmio a grupos está causando problemas frequentes e dando a impressão distorcida e injusta de como a ciência é realmente produzida".

O grupo 5 selecionou uma temática envolvendo um evento de vazamento de e-mails de cientistas climatologistas, que ficou conhecido como caso "Climategate". Em 2009, mais de 1000 e-mails de cientistas e ambientalistas foram hackeados e divulgados na internet. Junto com este vazamento, vieram acusações de que os cientistas estavam manipulando dados para defenderem a interpretação de que o homem interfere diretamente nas questões climáticas. O grupo selecionou três textos relacionados a esta temática: Scientists Respond to "climategate" E-mail Controversy ${ }^{44}$, publicado em 4 de dezembro de 2009 na revista Scientific American, assinado por David Biello; Climategate, the sequel: How we are still being tricked with flawed data on global warming 45 , publicado em 24 de janeiro de 2015 no jornal The Telegraph e assinado por Christopher Booker ; $O$ aquecimento global desacelerou ${ }^{46}$ publicado na revista VEJA em 11 de julho de 2015, assinado por Raquel Beer.

\footnotetext{
${ }^{44}$ Disponível em: https://www.scientificamerican.com/article/scientists-respond-to-climategatecontroversy/.último acesso em 24/06/2019 às $15 \mathrm{~h} 13$.

${ }^{45}$ Disponível em: https://www.telegraph.co.uk/comment/11367272/Climategate-the-sequel-How-weare-STILL-being-tricked-with-flawed-data-on-global-warming.html. Último acesso em 24/06/2019 às $15 \mathrm{~h} 32$.

${ }^{46}$ Disponível em: https://veja.abril.com.br/ciencia/o-aquecimento-global-desacelerou/. Último acesso em 24/06/2019 às $15 \mathrm{~h} 34$.
} 
O subtítulo do texto publicado pela Scientific American indica o enredo da produção: "E-mails roubados e códigos de computador não mudam as tendências de temperatura média, mas podem prejudicar a credibilidade dos pesquisadores climáticos quando as pesquisas mostram a diminuição da crença pública de que os gases do efeito estufa estão aquecendo o planeta”. A matéria é iniciada afirmando que em meio à "febre" acerca das discussões sobre mudanças climáticas em 2009, nenhuma foi "mais quente" do que o vazamento de emails provindos do Climatic Research Unit (CRU) na Universidade East Anglia, na Inglaterra. Apresentam o posicionamento de algumas figuras de destaque, como a do senador James Inhofe, que interpretou o vazamento dos emails como uma "reviravolta" nas evidências científicas sobre o aquecimento global. Apontam pesquisas recentes à época que mostravam que menos americanos, em relação com os dois anos anteriores à pesquisa, acreditavam que os gases de efeito estufa causariam aumentos nas temperaturas médias - uma queda de $71 \%$ para $51 \%$.

David Biello se posiciona e afirma que nada nos e-mails roubados ou códigos de computadores enfraquece de qualquer forma o consenso científico que a mudança climática está acontecendo e os humanos são a causa. Afirma, ainda, que parte do tumulto repousa sobre uma leitura errada do texto dos e-mails. Por exemplo, a palavra trick em uma mensagem, que foi citada como evidência de que uma conspiração está em andamento, na verdade está sendo usada, de acordo com Biello, para descrever uma abordagem matemática para reconciliar as temperaturas observadas com os dados de referência [stand-in] inferidos de medições de anéis de árvores.

A reportagem também chama a atenção para críticas, encontradas nos emails vazados, a alguns periódicos científicos com revisões paritárias pouco rigorosas. Nos emails vazados, afirma a matéria da Scientific American, encontram-se diálogos sugerindo que alguns artigos sejam mantidos de fora do relatório do IPCC. De acordo com Biello, os e-mails vazados fornecerão uma "janela sociológica" para o funcionamento da comunidade científica. Destaca a fala de Schimit, que afirmou que "Este é um registro de como a 
ciência realmente é feita [...] Eles irão ver que cientistas são humanos e como a ciência progride apesar das falhas humanas".

A reportagem do jornal britânico The Telegraph publicada em 2015 é iniciada com uma imagem parcial da Terra, na qual se pode ver uma extensa camada de gelo. A legenda da imagem indica que as temperaturas estão entre as mais baixas desde a última era glacial. A primeira afirmação da matéria assinada por Christopher Booker é que embora o caso Climategate tenha surgido há sete anos ou mais, "um dos mais extraordinários escândalos de nosso tempo nunca chegou às manchetes". Booker chama atenção de outro evento que indica, para ele, que os dados sobre o aquecimento global estão sendo manipulados. Chama atenção para uma manchete de um blog sobre o clima, intitulada "Adulteração maciça de temperaturas na América do Sul”. Booker destaca investigações feitas por Paul Homewood. Intrigado com as afirmações de que o ano de 2014 foi o mais quente já registrado, lideradas pelo mais citado de todos os cinco recordes oficiais de temperatura global - o Instituto Goddard de Estudos Espaciais (GISS) da Nasa - Homewood examinou um lugar no mundo onde GISS estava mostrando temperaturas subindo mais rápido do que em quase qualquer outro lugar: um grande pedaço da América do Sul que se estende do Brasil ao Paraguai. De acordo com Booker, Homewood conseguiu verificar os dados do GISS em relação aos dados originais dos quais eles foram derivados, e descobriu que eles haviam sido alterados. Homewood mostrou, de acordo com a matéria do The Telegraph, que as temperaturas de fato diminuíram ao longo de um intervalo de 65 anos, entre 1950 e 2014.

Booker ainda chama atenção para metodologias distintas de análise de dados sobre o clima. Para ele, essas formas de medir a temperatura global têm mostrado cada vez mais resultados diferentes. Com relação às metodologias que indicam aumento das temperaturas globais, Booker aponta dois aspectos que, segundo ele, há muito tempo vêm preocupando um crescente número de estatísticos, meteorologistas e blogueiros especializados em ciência. Uma é que a rede supostamente mundial de estações das quais o GHCN (Global Historical Climate Network ) extrai seus dados é falha. Até 
80 por cento ou mais da superfície da Terra não são cobertos de forma confiável, afirma Booker. Afirma, ainda, que por volta dos anos de 1990, o número de estações diminuiu pela metade, de 12.000 para menos de 6.000 e a maioria permanece concentrada em áreas urbanas ou locais onde estudos mostraram que, graças ao "efeito de ilha de calor urbana", as leituras podem ser até 2 graus mais alto do que naquelas áreas rurais, onde milhares de estações foram perdidas.

A conclusão da reportagem afirma que além dessas distorções de dados serem "aberrações bizarras" na história da ciência, implicam nas políticas adotadas pela Grã-Bretanha, particularmente sobre a política energética.

A matéria da revista VEJA selecionada pelo grupo 5 é iniciada com uma imagem de uma placa de gelo se quebrando. $\mathrm{Na}$ legenda, a afirmação de que "o aquecimento de camadas profundas dos oceanos acarreta em alterações na salinidade, na acidez e nas correntes da água do mar”. A primeira afirmação da matéria é que não há como negar que o planeta está aquecendo. Raquel Beer, que assina a reportagem da VEJA, afirma que desde 1880, quando começaram os registros formais, a temperatura subiu 0,8 grau, e dois terços desse aumento aconteceu nos últimos 40 anos. O ponto principal da matéria é a ponderação de que embora o planeta esteja aquecendo, esse ritmo de aumento tem diminuído, ao contrário de previsões de climatologistas, afirma Beer.

A matéria da VEJA destaca um estudo desenvolvido pela NASA e publicado na revista Science que "acaba com os argumentos dos céticos". A principal tese do estudo, de acordo com Beer, é que o calor acumulado nos últimos anos na atmosfera e pela água dos mares se deslocou para camadas mais profundas dos oceanos. Esse calor, porém, deve voltar à superfície a curto prazo, aumentando bruscamente a temperatura global. A matéria considera que a conclusão é importante ainda por revelar com mais detalhes como os oceanos agem como reguladores da temperatura do planeta. "Se não fosse pelos mares, a atmosfera teria aquecido mais de 1,5 graus nos últimos 
150 anos, e não 0,8 grau, agravando a situação já ruim”, diz o climatologista Paulo Artaxo, da Universidade de São Paulo. Logo após a fala de Paulo Artaxo, Beer destaca que as discussões sobre mudanças climáticas teve idas e vindas, afirmando que enquanto se acumulavam evidências de que o aumento de temperatura estaria ligado à emissão de gases de efeito estufa pelo homem, havia céticos que se opunham a essas explicações. A tese dos céticos ganhou força, de acordo com a matéria, em 2009 quando aconteceu o escândalo apelidado de "climategate", caso dos emails de climatologistas que foram vazados e que indicavam supostas manipulações de dados. Beer também aponta um relatório do Painel intergovernamental sobre Mudanças Climáticas (IPCC) no qual havia alegações mentirosas sobre os glaciares do Himalaia. Com estes dois casos, a matéria da VEJA afirma que a reputação do IPCC e dos cientistas que defendiam o aquecimento global foi abalada, mesmo depois de a instituição ter reconhecido as falhas e se desculpado por elas, e de as investigações instauradas para averiguar o climategate reconhecerem que os cientistas eram inocentes das acusações.

Por fim, Beer coloca as pesquisas sobre o "hiato" do aquecimento global, cuja tese é que o aquecimento teria desacelerado pelo armazenamento de calor em áreas mais profundas dos oceanos, como um argumento para que os céticos repensem seus argumentos. Usa como exemplo o físico Richard Muller que, segundo Beer, era um pesquisador que compunha o grupo dos "descrentes", mas que reconheceu que a melhor explicação para o aquecimento do planeta é mesmo a emissão de gases estufa pelo homem.

A seguir apresentamos um gráfico contendo o número de ocorrências com que diferentes canais de comunicação foram selecionados pelos licenciandos. Consideraremos entre os dados a reportagem da Globo que foi uma réplica do texto da BBC Brasil, apontada pelo grupo 2. 


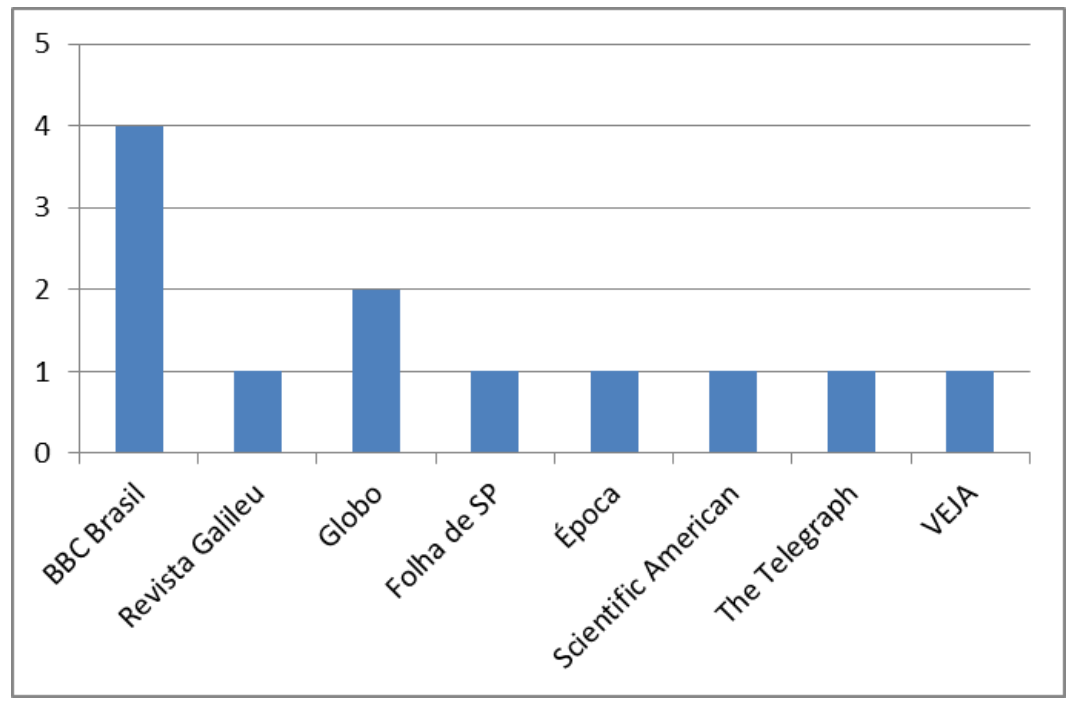

Considerando que tanto a revista Galileu quanto a revista Época compõem o grupo Globo, podemos apresentar o gráfico acima da seguinte maneira:

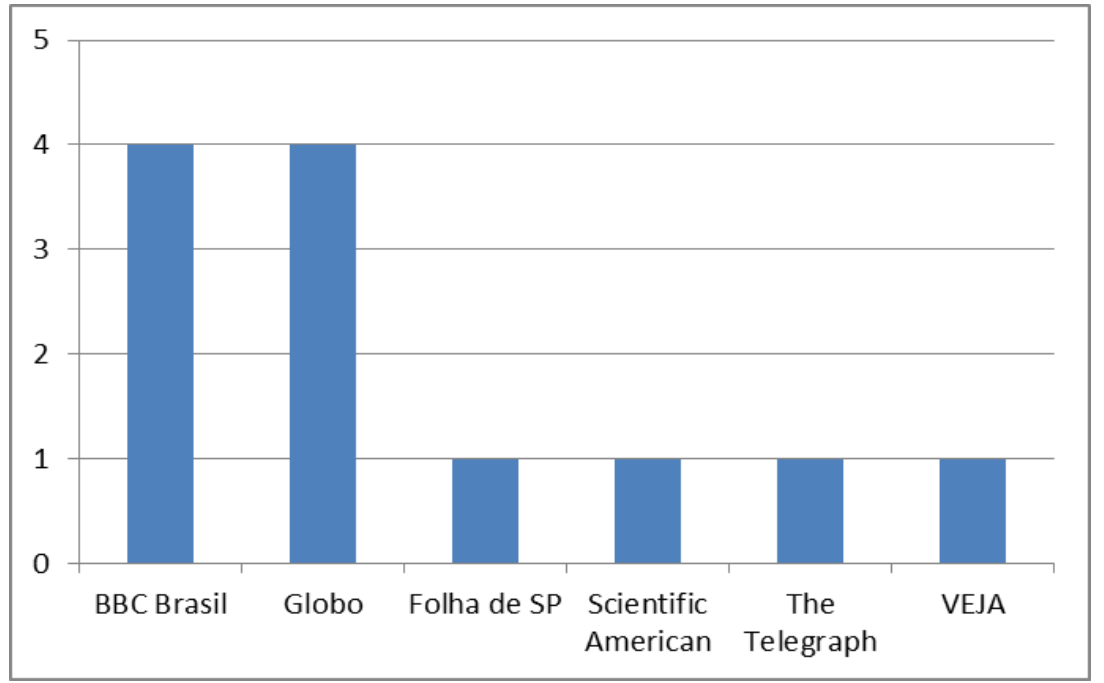

Como indicado pela pesquisa de consumo de mídia (SECOM, 2016) a Globo é um dos principais canais de comunicação consumidos pela população brasileira, não só através da televisão, mas também por outros meios de comunicação, como a mídia escrita (impressa e/ou digital). Esta ampla participação do grupo Globo foi traduzida nas reportagens científicas selecionadas pelos licenciandos. Vale destacar que a seleção dos materiais foi feita de maneira totalmente independente pelos grupos. Nos chama atenção, também, que a $\mathrm{BBC}$ Brasil se destacou dentre as reportagens selecionadas pelos licenciandos. 
A seguir apresentaremos as análises dos materiais desenvolvidos pelos grupos de EDC. A análise é pautada nos três eixos indicados nos capítulos anteriores: Mídia, Ciência e Ensino. Em cada um desses eixos, apresentamos categorias que emergiram da fundamentação teórica da tese, principalmente a partir do capítulo 5, em que buscamos delinear alguns parâmetros para a aproximação entre a educação para as mídias e o ensino de ciências. Essas categorias foram divididas em subcategorias, de acordo com nossa impregnação com o corpus da tese. Assim, o quadro analítico construído é um misto de categorias a priori e subcategorias a posteriori. Em outras palavras, nossa categorização combina tanto o método dedutivo quanto o indutivo.

A seguir apresentamos um quadro no qual há os três eixos de análise assim como seus desdobramentos em categorias e subcategorias. A última coluna deste quadro indica em quais materiais de nosso corpus são encontradas ocorrências que se enquadram em cada uma das subcategorias. A categorização está relacionada a aspectos mais amplos das produções dos grupos, enquanto as subcategorias têm a intenção de interpretar as particularidades das produções que compõem nosso corpus. 


\begin{tabular}{|c|c|c|}
\hline Categorias & Subcategorias & Ocorrências \\
\hline \multicolumn{3}{|c|}{ Mídia } \\
\hline \multirow{3}{*}{$\begin{array}{l}\text { Contraditório e } \\
\text { confrontação de } \\
\text { diferentes materiais }\end{array}$} & Seleção de materiais com temáticas diferentes & Grupos 1 e 2 \\
\hline & $\begin{array}{l}\text { Seleção de materiais com mesma temática e } \\
\text { abordagens não conflituosas entre si. }\end{array}$ & Grupos 2,3 e 4 \\
\hline & $\begin{array}{l}\text { Seleção de materiais com mesma temática e } \\
\text { abordagens conflituosas entre si }\end{array}$ & Grupo 5 \\
\hline Questão do Poder & Mídia "orquestrando" controvérsias & Grupo 5 \\
\hline \multirow[t]{3}{*}{ Usos da Linguagem } & $\begin{array}{l}\text { Hiperlinks } \\
\text { Discursos indiretos }\end{array}$ & $\begin{array}{l}\text { Grupo } 3 \\
\text { Grupo } 1\end{array}$ \\
\hline & Analogias & Grupo 4 \\
\hline & Simplificação & Grupos $1,3,4$ e 5 \\
\hline \multicolumn{2}{|l|}{ Sensacionalismo } & Grupos 1,4 e 5 \\
\hline \multicolumn{3}{|c|}{ Ciência } \\
\hline \multirow{5}{*}{$\begin{array}{l}\text { Relações entre } \\
\text { Ciência, Tecnologia } \\
\text { e Sociedade }\end{array}$} & Credibilidade da Ciência na Sociedade & Grupo 1 \\
\hline & Financiamento científico & Grupo 2 e 3 \\
\hline & Interferência política na prática científica & Grupo 5 \\
\hline & Aplicações e desenvolvimento tecnológico & Grupos 2,3 e 4 \\
\hline & Questões Éticas & Grupo 5 \\
\hline \multirow{3}{*}{$\begin{array}{l}\text { Aspectos } \\
\text { Epistemológicos }\end{array}$} & Mito do Gênio & Grupos 4 e 5 \\
\hline & Cooperação internacional na Ciência & Grupo 2 \\
\hline & Papel do Experimento na Ciência & Grupo 3 \\
\hline \multicolumn{3}{|c|}{ Ensino } \\
\hline \multirow{4}{*}{ Problematização } & Problematização da Mídia & Grupos 4 e 5 \\
\hline & Problematização da Ciência & Grupo 3 \\
\hline & Problematização da Mídia e da Ciência & Grupo 5 \\
\hline & Ausência de problematizações & Grupo 1 \\
\hline \multirow{2}{*}{$\begin{array}{l}\text { Relação Professor- } \\
\text { Conhecimento-Aluno }\end{array}$} & Relação dialógica & Sem ocorrências \\
\hline & Relação expositiva & Grupos $1,2,3,4$ e 5 \\
\hline \multirow{2}{*}{$\begin{array}{l}\text { Seleção de } \\
\text { conhecimentos } \\
\text { Científicos }\end{array}$} & $\begin{array}{l}\text { Seleção de conteúdos científicos tradicionais } \\
\text { contextualizados }\end{array}$ & Grupo 5 \\
\hline & $\begin{array}{l}\text { Seleção de conteúdos científicos não } \\
\text { tradicionais }\end{array}$ & Grupos $1,2,3$ e 4 \\
\hline
\end{tabular}




\subsubsection{Categorização: Foco na Mídia}

A seguir apresentaremos alguns extratos das produções dos licenciandos, provenientes tanto dos relatórios quanto dos vídeos que compõem nosso corpus. Esses extratos são acompanhados de textos descritivos que buscam contextualizar tanto as falas dos licenciandos como a categorização dessas falas. Nesta seção focaremos no eixo da mídia e, na sequência, faremos o mesmo para os eixos da ciência e do ensino. Após este processo de organização dos textos de nosso corpus em categorias, apresentaremos nossas interpretações em um metatexto construído com base no processo de categorização e na fundamentação teórica desta tese.

\section{Contraditório e Confrontação de diferentes materiais}

A seleção de mais de um material sobre o tema selecionado por cada grupo era uma exigência da atividade sugerida aos licenciandos. A exigência é que fossem selecionados, no mínimo, dois materiais diferentes para um mesmo tema. Dos cinco grupos, apenas o grupo 5 selecionou mais de dois materiais diferentes. Desdobramos essa categoria em três subcategorias: seleção de materiais com temáticas diferentes; Seleção de materiais com mesma temática e abordagens não conflituosas entre si; Seleção de materiais com mesma temática e abordagens conflituosas entre si.

\section{Seleção de materiais com temáticas diferentes}

Os grupos 1 e 2 selecionaram reportagens que, a rigor, abordavam temas diferentes. Assim, a ideia de confrontar diferentes perspectivas não poderia se concretizar. O grupo 1 selecionou uma notícia que versava sobre o acidente em Fukushima e outra notícia que falava sobre as bombas atômicas de Hiroshima e Nagasaki e do acidente em Chernobyl. O grupo 2 selecionou uma reportagem sobre estudos desenvolvidos acerca de eventuais tipos de vida que poderiam existir na Europa, lua de Júpiter, e que versava particularmente sobre investigações de bactérias extremófilas como as encontradas em uma mina de ouro na África do Sul. A outra notícia versava sobre o anúncio de uma missão da NASA à Europa, lua de Júpiter. Embora 
as reportagens selecionadas pelos grupos 1 e 2 tenham pontos de intersecção, não permitem o exercício crítico de confrontar diferentes pontos de vistas, simplesmente porque não versam sobre o mesmo tema. Também chama atenção, com relação à possibilidade de confrontação, que o grupo 1 selecionou duas reportagens do mesmo canal de comunicação, BBC Brasil.

A confrontação feita pelo grupo 1 fica restrita à forma como são apresentados os dados e o uso dos especialistas como forma de justificar seus pontos de vista. De acordo com o grupo, ambas as reportagens selecionadas não apresentam de maneira adequada suas referências e usam de forma genérica a figura do especialista.

Uma coisa curiosa que acontece nas duas notícias é que eles não dão referências, não dão contrapontos. Focam, principalmente na primeira notícia, nos especialistas. Toda hora eles falam: os especialistas afirmam...especialistas disseram tal coisa. Mas quem são esses especialistas? É um grupo de engenheiros e físicos? Ou pegou de algum outro lugar? Eles nunca citam. Então eles cozinham a gente pra ler a notícia e só acreditar, como se a gente não fosse questionar. Não cabe a gente questionar, porque não tem nem como a gente ir atrás. De onde tirou essa notícia? Ou pelo menos, de onde tiraram este estudo? (VEDC1).

\section{Seleção de materiais com mesma temática e abordagens não conflituosas entre si}

Em sua análise, o grupo 2 buscou comparações entre produções que, como apontamos anteriormente, não abordavam a mesma temática, embora com intersecções entre si. Contudo, o grupo 2 aponta em sua análise uma reportagem publicada no site da Globo, na qual o mais influente conglomerado de comunicação do país reproduz o texto publicado pela BBC. A rigor a comparação entre esses dois materiais, que são exatamente o mesmo, indica um processo de homogeneização das produções midiáticas sobre ciência. 
A propagação da ciência por alguns meios de comunicação são basicamente "ctrl+c e ctrl+v", onde não há uma leitura prévia para a publicação de tal notícia. Exemplo do que foi citado é a replicação da notícia da BBC no site da Globo (Ciência e Saúde) - link da notícia replicada, para caráter de curiosidade é http://g1.globo.com/ciencia-esaude/noticia/2014/03/nasa-anuncia-missao-para-lua-de-jupiter-quepode-ter-vida.html-, onde até mesmo o erro gramatical encontrado ("Ciensitas") foi replicado sem a devida correção (TEDC2).

Na apresentação do seminário o grupo afirma que o site da Globo dá os créditos à $\mathrm{BBC}$, mas de maneira pouco clara.

Na notícia do Globo a gente detectou uma falha: que eles copiam a $B B C$. Eles literalmente fazem ctrl $C+c t r l ~ V$, só que eles dão os créditos ali bem no cantinho, muito pequenininho. E eles não leram a matéria, porque está escrito ao invés de "cientistas", "ciensitas". Então tem um erro ortográfico que literalmente eles fizeram um ctrl $C$ + ctrl V. Eles não olharam na hora de publicar (VEDC2).

Abaixo segue uma imagem com a visão geral do site. Inserimos uma seta que indica a única referência à $\mathrm{BBC}$, mencionada pelos licenciandos.
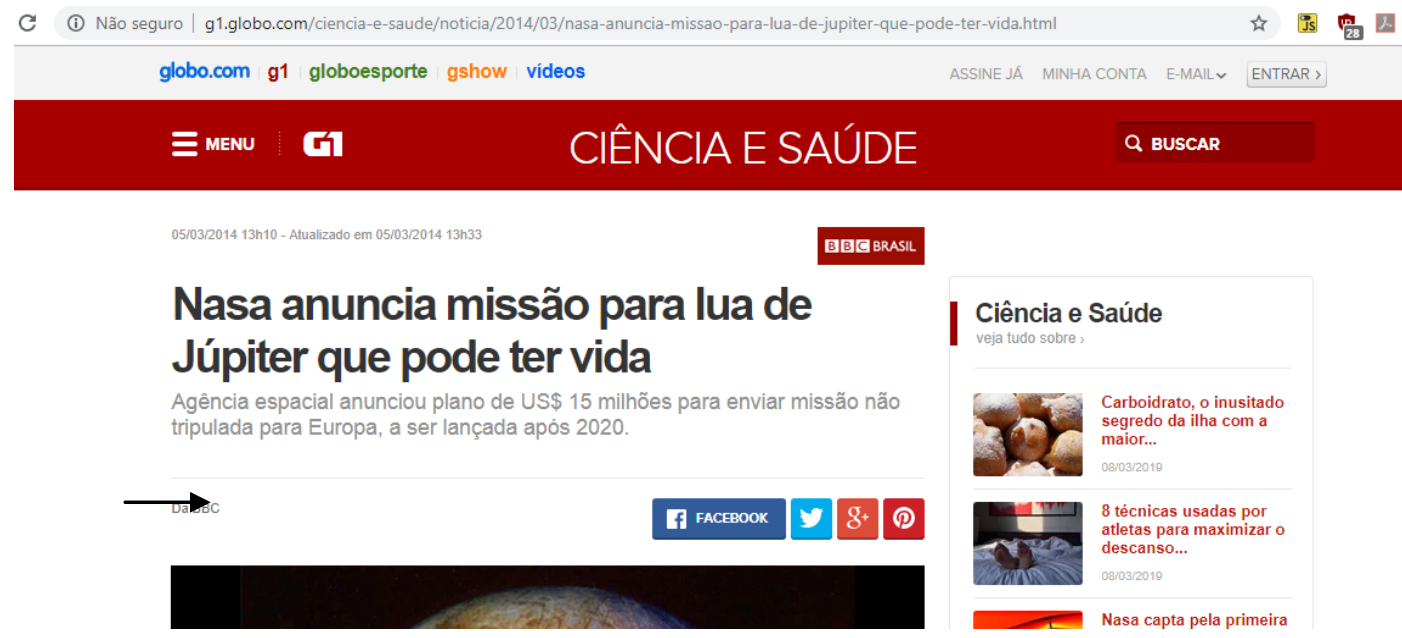
O grupo 4 compara diretamente os materiais selecionados, em busca de compor uma visão mais complexificada do tema abordado. A este respeito afirmam o seguinte:

[...] pode-se destacar que em ambos os textos encontram-se exageros $e$ distorções das informações sobre a proporção das ondas encontradas, pois nos dois textos são citadas proporções diferentes, e isso pode causar confusão ao leitor ao querer conhecer um valor próximo, já que esses são sites bem conceituados na sociedade. (TEDC4)

Seria impossível saber se os dados apresentados, as ordens de grandeza, as proporções, etc. são adequadas se não fosse feita uma confrontação entre materiais diferentes. Nesta crítica específica, a comparação entre dois materiais também não soluciona o problema, embora o identifique. Assim, seria importante a confrontação dos dados apresentados em ambas as reportagens com uma terceira, além da confrontação com fontes primárias: neste caso os artigos científicos publicados sobre a detecção das ondas gravitacionais.

\section{Seleção de materiais com mesma temática e abordagens conflituosas entre si}

O grupo 5 lidou com o exercício crítico da confrontação entre pontos de vistas de maneira mais consciente e explícita, se comparado aos demais grupos. Chama atenção que este foi o único grupo que descreveu características dos canais de comunicação selecionados e teceu considerações sobre como essas características implicam na forma como constroem seus argumentos e defesas. Assim, intencionalmente o grupo selecionou um material que teria propensão a defender os cientistas acusados de manipular os dados sobre mudança climática e outro material que tenderia a atacar os cientistas e a ideia de um aquecimento global antropocêntrico.

A Scientific American é uma revista de divulgação científica. Então, obviamente, ela ia sair em defesa aos cientistas. Então, já que a gente pegou um revista que defende tanto os cientistas, deixa eu pegar uma 
que vai atacar, com certeza. [Pegamos] um jornal do Reino Unido, extremamente conservador [The Telegraph]. (VEDC5)

\section{Exercício do poder}

Dos cinco grupos, apenas um considerou diretamente a questão do poder relacionado à mídia. Em particular, o grupo 5 usou a fala de um político afirmando que a controvérsia acerca dos e-mails dos climatologistas que foram vazados no caso climategate havia sido orquestrada por parte da mídia.

Sherwood Boehlert, ex-presidente do Comitê de Ciências da Casa Republicana, chamou os ataques de "distração fabricada" e a disputa, uma controvérsia "altamente orquestrada" e fabricada pela Newsweek e pelo The New York Times. (TEDC5)

A partir dessa fala, o grupo considera as implicações que as narrativas da mídia podem desempenhar na visão de mundo das pessoas.

A mídia tem uma parte muito importante na moldagem do pensamento do publico, ou seja, a circulação de tal acontecimento, trazendo alegações precipitadas, mas não fazendo o mesmo furdunço livrando os cientistas não envolvidos, e isso foi uma preocupação geral já que isso poderia implicar no julgamento de uma comunidade inteira de cientistas. (TEDC5)

Chama atenção que os licenciandos se posicionam diante do tema abordado. Claramente o grupo critica a maneira como parte da mídia tratou o caso climategate, em particular pelo ataque à credibilidade do trabalho de alguns cientistas.

O grupo 5 ainda critica de maneira mais incisiva o jornal The Telegraph, classificando-o como extremista.

Ao efetuar a leitura do texto, sabendo das fontes dos dados (e o quão ultrapassados estão) e da reputação do jornal, é improvável que o leitor não assemelhe-o a um blog extremista ou a publicações do 
Facebook em frente ao clima de muita mentira e dominante revolta (TEDC5).

Entendemos ser direito dos licenciandos se posicionarem contrários a determinado meio de comunicação. É fundamental que se apresente e defenda seus posicionamentos. Igualmente fundamental é não impô-los, mas apresentá-los de maneira dialógica e enfatizando os conflitos e interesses relacionados ao exercício do poder.

\section{Usos da Linguagem}

\section{Hiperlinks}

Uma característica de usos da linguagem que surgiu entre as análises dos grupos foi algo próprio das produções digitais e que se configura como um recurso tecnológico interessante: uso de hiperlinks.

A associação ao sistema moderno traz, na sua versão online, muitos links e palavras destacadas para ter um aprofundamento compensador afim de estruturar uma linha sequencial do fenômeno. (TEDC3)

O grupo chama atenção, portanto, de um recurso que as produções midiáticas online usam para que seus leitores possam, a qualquer momento, aprofundar em pontos específicos do texto através de links diretos a outros textos.

\section{Discursos indiretos}

O grupo 1 identificou como um dos recursos de linguagem utilizados nos materiais que analisaram o uso de discursos indiretos, usando principalmente a autoridade dos cientistas para construir enunciações com locutores tidos como especialistas. A este respeito afirmam o seguinte:

Usam como argumento de autoridade "os especialistas disseram...", como se fosse uma coisa única, perfeita e inquestionável, que não cabe aos leitores questionarem, por exemplo se foi uma equipe e quais áreas da ciência englobaram. (TEDC1) 
Cabe salientar que não só identificam o uso de enunciadores da ciência, como criticam este uso como forma de apresentar um "verniz de verdade".

\section{Analogias}

Outra característica linguística identificada pelos licenciandos nas produções midiáticas foram as analogias. Este é um recurso recorrente, em particular na busca pela reconstrução do discurso da ciência para o público geral.

Analisando o artigo do jornal BBC, percebe-se que ele descreve o fenômeno das ondas gravitacionais em somente um parágrafo, comparando a sua dispersão com o exemplo das pequenas ondas que as pedras fazem quando caem em um rio (TEDC4).

\section{Simplificação}

A simplificação é uma das características mais apontadas pelos licenciandos em suas análises dos materiais midiáticos selecionados. O próprio contexto em que estão inseridos, formação de futuros professores de física, faz com que apontem a falta de conceitos científicos nos materiais analisados e suas supostas abordagens superficiais.

[...] como estamos estudando licenciatura em Física é importante a gente deixar claro que lá não vai explicar Física, os caras só vão falar superficialmente (VEDC1).

Os apontamentos dos licenciandos estão atrelados recorrentemente à insuficiente abordagem dada aos conceitos científicos. Em nosso corpus temos alguns exemplos desses apontamentos.

[...] a maneira como a revista explica o conceito físico por detrás da descoberta é simples e rápida, porém deixa a desejar, pois não explica $o$ suficiente para o leitor entender de forma completa o assunto. (TEDC4) 
A matéria jornalística não entra muito nos conceitos físicos, quando é inevitável não abordá-los, acabam por serem apresentados de forma superficial, jogam termos físicos sem nenhuma explicação, dando a entender que os termos como "Césio" já são inteiramente conhecidos pela população (TEDC1).

O grupo 1, em particular, associa o processo de simplificação à apresentação de conceitos científicos de maneira errônea.

Ora explicam termos físicos de maneira muito simplificada, ao ponto de serem errôneos, como quando falam das delimitações de alcance da radiação e sobre o decaimento radioativo. (TEDC1)

A linguagem do texto é muito simplificada, ao ponto de ser questionável (TEDC1).

O grupo 1 também chama atenção de que esse processo de simplificação está atrelado à busca, legitima em nossa opinião, por aproximar o público leigo de assuntos da ciência. Contudo, este processo pode resultar, na concepção do grupo 1, em textos mais chamativos mas que acabam sendo incompreensíveis, principalmente por usarem termos científicos sem aprofundá-los.

[...] ora jogam termos da área da ciência, sem maiores explicações, e o fazem dessa maneira por que o seu público alvo são as pessoas leigas, mas essa tentativa de simplificação faz o público leigo receber uma matéria chamativa, com termos que não compreendem, o que acaba por não se fazendo entender totalmente, sem um conhecimento prévio básico do assunto (TEDC1).

\section{Sensacionalismo}

Em nosso corpus temos exemplos de análises que indicam o uso do sensacionalismo em materiais selecionados pelos licenciandos. Esses apontamentos se dão de maneiras diferentes. Por um lado, o grupo 1 conclui que os materiais que selecionaram se comprometeram apenas com a 
publicidade do evento científico, relacionados a acidentes nucleares, apelando, principalmente, para os impactos de destruição causados pela energia nuclear liberada no acidente de Fukushima, Chernobyl e relacionados às bombas atômicas lançadas sobre Hiroshima e Nagasaki.

A matéria não se preocupa com a divulgação científica, mas tão somente com a publicidade do evento, utilizando do sensacionalismo dos impactos e destruição ocorridos (TEDC1).

O grupo 4, por sua vez, chama atenção do uso do sensacionalismo na maneira como projeta a imagem de Einstein ao abordar o tema das ondas gravitacionais. É um sensacionalismo pautado na imagem distorcida sobre o cientista, relacionada ao mito do gênio.

Percebe-se claramente que há sensacionalismos nos nomes encontrados nas manchetes. No artigo do jornal $B B C$, este feito acontece ao dizer que "Einstein sempre está certo" e colocar no nome de destaque "mais uma vez está certo", para algo que provavelmente possuiu toda uma equipe grande trabalhando por trás e apenas um único cientista é que leva todo o prestígio (TEDC4).

\subsubsection{Categorização: Foco na Ciência}

\section{Relações CTS}

A análise de nosso corpus nos levou a interpretar que a própria seleção dos temas empreendida pelos grupos teve como critério os impactos sociais, tecnológicos e ambientais relacionados à ciência. Esta busca por aproximar a ciência de questões com relevância social é uma característica da própria mídia, que busca sempre a maior audiência possível e, portanto, produz seus materiais de modo que tenham impacto sobre os possíveis leitores, telespectadores, ouvintes etc.

O grupo 1 selecionou o tema de acidentes e bombas nucleares. O grupo 2 selecionou o tema de vida extraterrestre que, além de envolver questões existenciais como a possibilidade de vida fora de nosso planeta, lida 
com questões de avanços tecnológicos de ponta para o lançamento de sondas espaciais. Os grupos 3 e 4 selecionaram o tema das ondas gravitacionais. Este é o tema que a priori parece ser mais interno à própria ciência. Contudo, tem uma série de relações com a sociedade, como o financiamento dos laboratórios que detectaram as ondas, os desdobramentos relacionados ao prestígio alcançado pelos cientistas envolvidos, sobretudo através de premiações como o Nobel, além de perspectivas de desenvolvimento de novas tecnologias atreladas às ondas gravitacionais. O grupo 5 selecionou um evento controverso sobre o vazamento de emails de climatologistas, que colocou em debate a credibilidade da ciência na sociedade, além de estar relacionado a questões climáticas, que tem sido uma das principais preocupações entre cientistas, políticos e cidadãos.

Em nosso corpus, considerando os 5 grupos, temos a presença de diferentes aspectos relacionados a relações entre Ciência, Tecnologia e Sociedade, tais como sobre a credibilidade da Ciência na sociedade, questões sobre financiamento, questões éticas, investigação e interferência política na prática científica, aplicações e desenvolvimento tecnológico.

\section{Interferência política na prática científica}

Com relação à interferência política na prática científica, o grupo 5 destaca a fala do político britânico Lord Lawson, cobrando apurações sobre a possível manipulação de dados climáticos para defender a interpretação de um aquecimento global antropocêntrico.

Nos Estados Unidos e na Inglaterra foram solicitados pedidos de investigações oficiais, já que certos assuntos discutidos nos e-mails mexiam com questões diplomáticas. O político conservador britânico Lord Lawson disse: "A integridade da evidência científica... tem sido questionada. E a reputação da ciência britânica tem sido seriamente prejudicada. Uma investigação independente de alto nível deve ser realizada sem demora". (TEDC5). 
Este extrato da análise feita pelo grupo 5 mostra como os licenciandos destacaram os desdobramentos da ciência na organização social, particularmente relacionada à classe política da Inglaterra, onde ocorreu o caso dos vazamentos dos emails. Frisam que a interferência política foi feita por um conservador, supostamente preocupado com a integridade da evidência científica. Esta interferência está diretamente ligada, portanto, à preocupação com a credibilidade da ciência entre os cidadãos e cidadãs.

\section{Credibilidade da Ciência na Sociedade}

O grupo 5 usa o caso climategate, e a análise que fizeram dos materiais selecionados, para discutir a credibilidade da ciência entre os cidadãos, que poderia ser questionada a partir da eventual manipulação de dados a que estavam sendo acusados os cientistas. A este respeito citam uma pesquisa de 2010 feita pela Universidade de Yale sobre os efeitos do caso Climategate sobre a confiança das pessoas nos cientistas e na ciência.

O diretor do Projeto da Universidade de Yale sobre Mudança Climática A. A. Leiserowitz e seus colegas descobriram em 2010 que: "Climategate teve um efeito significativo sobre as crenças públicas no aquecimento global e confiança nos cientistas. A perda de confiança nos cientistas, no entanto, foi principalmente entre indivíduos com visão de mundo fortemente individualista ou ideologia politicamente conservadora. No entanto, os americanos em geral continuam a confiar nos cientistas mais do que em outras fontes de informação sobre o aquecimento global."(TEDC5).

Este caso pode produzir perda de confiança na ciência por parte dos cidadãos, como indicou a pesquisa mostrada pelo grupo 5, e abrir discussões sobre a prática científica, particularmente relacionadas a posturas éticas dos pesquisadores que supostamente teriam manipulado dados para defenderem sua tese. 


\section{Questões Éticas}

A este respeito, discussões sobre a postura ética dos cientistas, o grupo 5 destaca o pronunciamento da Sociedade Meteorológica Americana, que defende que há uma crescente obviedade da ação humana sobre o clima e que o caso dos emails vazados, mesmo se comprovadas as manipulações de dados [o que não ocorreu!], não seriam suficiente para desbancar essa compreensão.

Para a pesquisa sobre mudanças climáticas, o corpo de pesquisa na literatura é muito grande e a dependência de qualquer conjunto de resultados de pesquisa para a compreensão abrangente do sistema climático é muito, muito pequena. Mesmo que algumas das acusações de comportamento impróprio neste caso específico se revelem verdadeiras - o que ainda não é claramente o caso - o impacto sobre a ciência da mudança climática seria muito limitado (TEDC5).

Esta passagem destaca pelo menos duas características da dinâmica da ciência: primeiro que as compreensões construídas acerca de determinados fenômenos da natureza dependem da convergência de muitos trabalhos e não apenas de um conjunto de dados isolado. Segundo, que pode haver "comportamentos impróprios" entre os integrantes da chamada "comunidade científica", embora isso não deva desabonar a atividade como um todo. Em outras palavras, a ciência não está isenta de que parte de seus integrantes tenham desvios éticos em suas práticas.

\section{Financiamento científico}

Em nosso corpus também são apresentadas considerações acerca do financiamento científico, e como o investimento em ciência é fundamental para a prática científica. O recorte em que esta questão fica mais evidenciada é na análise do grupo 3, quando comentam sobre o longo período desde a proposição das ondas gravitacionais no início do século $\mathrm{XX}$, passando pelas primeiras ideias de experimento na década de 70 , culminando com sua deteç̧ão em 2016. 
A parte mais intensa e diagnosticadamente importante da mensagem fica por conta da pergunta, "Porque demorou tanto", onde são levantados fatores relevantes, mesmos que implícitos, de que a ciência precisa de investimentos e que as descobertas precisam de uma sequência de estudos que, de forma constante, precisa do domínio financeiro para se ajustar. Essa elaboração mantém o crivo de que a descoberta só foi possível porque houve investimentos para a melhoria do equipamento de deteç̧ão (TEDC3).

Esta passagem evidencia tanto a historicidade da ciência, enfatizando o longo período de construção de uma ideia, de um experimento, etc, e também enfatiza a necessidade de investimentos financeiros, principalmente para o desenvolvimento de experimentos cada vez mais sofisticados para a produção de conhecimento científico. Também podemos destacar o avanço tecnológico envolvido em experimentos como o do laboratório LIGO, que detectaram as ondas gravitacionais.

\section{Aplicações e desenvolvimento tecnológico}

Os avanços tecnológicos foram a principal relação CTS indicada pelo grupo 4, que também selecionou o tema das ondas gravitacionais.

No que infere-se à sociedade, o impacto ainda não é claro de imediato, como é o caso de várias descoberta físicas. Um exemplo nítido são as ondas eletromagnéticas, descobertas em 1887, cujas aplicações na época ainda não existiam, mas que nos dias de hoje são utilizadas em diversos aparatos como televisores, celulares, microondas, etc. Assim, eventualmente, as ondas gravitacionais podem resultar em importantes aplicações no futuro, ademais também temos um modelo novo de experimentação desse fenômeno (TEDC4)

Assim, o grupo 4 destaca não apenas os avanços tecnológicos envolvidos na elaboração experimental relacionada à detecção das ondas gravitacionais, como também projetam possíveis desdobramentos futuros, fazendo paralelo com a proposição de ondas eletromagnéticas que hoje 
fundamentam grande parte do funcionamento de aparatos tecnológicos usados pelos cidadãos e cidadãs. As possibilidades abertas com as ondas gravitacionais não se limitam a possibilidades tecnológicas, mas também abrem novas possibilidades de investigar o universo, como destacam os integrantes do grupo 3. Um dos integrantes do grupo cita uma palestra assistida sobre a temática, em que a conclusão da pesquisadora era exatamente a abertura de possibilidades de investigação do universo a partir das ondas gravitacionais.

Lembro de uma palestra da SEDCITEC47 do ano passado [2017] que a conclusão da palestra dela [pesquisadora convidada] era a seguinte: tudo o que a gente conhece de astronomia até hoje é usando só o espectro eletromagnético. A descoberta das ondas gravitacionais tem esse peso todo porque justamente ela amplia a gama de possibilidades da gente investigar o universo. Então, a gente já quase esgotou a capacidade tecnológica em cima do espectro eletromagnético. E, agora com as ondas gravitacionais a gente vai duplicar toda evolução astronômica que a gente fez com base em um tipo de onda só, que é a onda eletromagnética. Agora a gente tá começando, engatinhando, nessa nova perspectiva de onda gravitacional. Então é por isso que essa descoberta traz esse peso gigantesco. A gente tem uma "puta" evolução em cima daquilo lá [refere-se ao experimento] e agora tem uma perspectiva cada vez maior.

Por fim, chamou-nos atenção um resultado de nosso corpus. Mais precisamente um comentário feito durante o seminário do grupo 3.

Em seguida, falando um pouquinho da sociedade, que o Professor colocou, se não me engano, que tinha que ter um impacto na sociedade...as ondas gravitacionais diretamente não têm impacto. Mas, em contrapartida, na nossa análise a gente colocou as ondas eletromagnéticas, que foram descobertas em 1887 e que a princípio

\footnotetext{
${ }^{47}$ Semana de Ciência e Tecnologia do Instituto Federal. É uma semana destinada a atividades relacionadas à Ciência e Tecnologia, na qual alunos, Professores e convidados organizam as mais variadas atividades, dentre elas palestras com especialistas.
} 
também não tinha nenhuma aplicação. Pode ser que no futuro as ondas gravitacionais tenham alguma aplicação. De imediato só tem a parte do experimento (VEDC3, grifos nossos).

Chama a atenção que o grupo se sentiu na obrigação de encontrar alguma relação com a sociedade no tema que selecionaram, de acordo com as discussões propostas pelo Professor. Em um primeiro momento, julgamos que isso indicava que a análise que os alunos fizeram dos materiais que selecionaram tinha o interesse de responder às expectativas do Professor (ou às expectativas que julgavam ser a do Professor), e que isso poderia ter comprometido o exercício crítico dos próprios licenciandos. Contudo, considerando que a educação é um exercício diretivo, não do Professor sobre os alunos, mas um processo diretivo do Professor com os alunos, interpretamos que essa fala expõe parte dos objetivos que traçamos ao propor esta temática aos Professores em formação, relacionada a problematização das relações entre ciência e sociedade.

\section{Aspectos epistemológicos}

Encontramos em nosso corpus exemplos de considerações epistemológicas nas análises dos licenciandos. São considerações a respeito da imagem que se faz dos cientistas, sobretudo buscando apontar as distorções como o mito do gênio; considerações sobre a dinâmica de construção da ciência como um processo histórico e não linear e que perpassa disputas entre teorias; o papel do experimento na construção da ciência; a cooperação entre cientistas e a convergência na coleta de dados para o estudo de um fenômeno;

\section{Papel do Experimento na Ciência}

O grupo 3 critica a maneira como a Folha de SP retrata o papel dos experimentos realizados pelo LIGO na detecção das ondas gravitacionais. Em particular, criticam a passagem na qual consideram o experimento como a primeira deteç̧ão irrefutável das ondas gravitacionais. É justamente a consideração do experimento como irrefutável que o grupo criticou. 
[...] físicos americanos anunciaram nesta quinta (11) a primeira deteç̧ão irrefutável de ondas gravitacionais um fenômeno que predito pela teoria da relatividade geral, publicada por Einstein cem anos atrás, mas que ainda não havia sido confirmado (FOLHA DE SP, 2016).

Com relação a esta passagem, os licenciandos afirmam o seguinte:

[...] dizer que na ciência há irrefutabilidade é como blasfemar contra Deus aos religiosos (TEDC3).

Entendemos que a colocação de Salvador Nogueira, da Folha de SP, tinha a intenção de frisar que outras tentativas de detecção tinham sido frustradas no passado e que essas, finalmente, teriam envergadura suficiente para não serem desconsideradas. Contudo, o uso do adjetivo "irrefutável" abre margem a críticas, como as empreendidas pelo grupo 3, sobretudo se consideramos como referência a epistemologia popperiana, que considera que as proposições científicas devem ser, necessariamente, refutáveis.

\section{Cooperação internacional na Ciência}

Ainda sobre a dinâmica de funcionamento da ciência, há no nosso corpus a consideração sobre a cooperação internacional da ciência, relatada sobretudo pelo grupo 2 .

Houve o engajamento de pesquisadores de vários países, não só dos EUA, como aqui na USP mesmo eles estavam estudando...tem esse professor [Douglas Galante, IAG - USP] que estava estudando a bactéria na África e tudo mais (VEDC2).

Além do grupo 2 que destaca positivamente a cooperação internacional da ciência presente nos materiais de mídia que analisaram, temos em nosso corpus críticas à forma como a cooperação internacional da ciência é considerada em uma produção midiática em particular. O grupo 3 
critica a reportagem da FOLHA de SP, por entenderem que essa produção supervalorizou a "supremacia dos EUA nas descobertas científicas".

[...] o artigo da Folha de S.paulo, reitera a supremacia dos E.U.A nas descobertas científicas, [...] como se não houvesse inteligência fora daquela nação e nesse caso a citação do nome de Brasileiros fica como um plano de fundo, só para o leitor não se entristecer com a história da ciência no Brasil.

\section{Mito do Gênio}

Além de considerações acerca da dinâmica da comunidade científica, temos considerações a respeito da imagem projetada do cientista. As discussões sobre tais imagens configuram-se como as principais considerações epistemológicas que constam em nosso corpus. Com relação ao tema das ondas gravitacionais, o grupo 4 critica a maneira como a mídia usa a imagem de Einstein em suas produções, sobretudo considerando que mais uma vez a história tratou de mostrar, através da detecção das ondas gravitacionais, a genialidade do físico alemão.

Percebe-se claramente que há sensacionalismos nos nomes encontrados nas manchetes. No artigo do jornal $B B C$, este feito acontece ao dizer que "Einstein sempre está certo" e colocar no nome de destaque "mais uma vez está certo", para algo que provavelmente possuiu toda uma equipe grande trabalhando por trás e apenas um único cientista é que leva todo o prestígio. E no artigo do site O Globo, vemos que os estudos de Einstein sobre relatividade geral concedem à três cientistas um Nobel de Física, como se Einstein tivesse realmente previsto que eles iriam ganhar prestígio com base nas suas pesquisas (TEDC4).

No caso dos vazamentos dos emails de climatologistas, os licenciandos também chamam atenção para a discussão sobre a imagem dos cientistas, sobretudo problematizando seu status de "ser perfeito" que não comete erros. 
A seleção de textos jornalísticos relacionados ao Climategate abre espaço para discussões sobre o fazer científico. Em vários trechos a problematização da imagem do cientista, um ser perfeito que sabe e entende tudo, é quebrada pelas falhas na análise dos dados, possibilitando também demonstrar como a construção do consenso teórico científico perpetua a imagem distorcida que temos sobre eles, então introduzindo uma discussão para expor a existência de várias teorias, estas que corroboram ou não com o consenso (TEDC5).

\subsubsection{Categorização: Foco no Ensino}

Este eixo da análise tem como intenção interpretar as maneiras como os licenciandos propuseram seus planos de aula buscando a aproximação entre ciência e mídia. Focamos, sobretudo, em como propuseram a inserção dos materiais de mídia em aulas de física, quais objetivos educacionais declararam a partir desta inserção, a seleção e a organização de conhecimentos em sequências de aulas, e como projetaram o posicionamento dos alunos (se passivo ou ativo e criativo) diante dos materiais de mídia e diante dos próprios assuntos científicos abordados.

\section{Problematização}

\section{Problematização da Mídia e da Ciência}

Nosso corpus indica que alguns grupos consideraram a apropriação de conhecimento científico como meio de atuação no mundo.

Em salas de aula, o mais importante é que o professor consiga incentivar seus alunos ao estudo da física, se não por interesse científico, para a construção de cidadãos críticos capazes de realizar a leitura de textos como estes e entender o que há nas entrelinhas, que busquem outras fontes de informação e consigam realizar suas próprias conclusões, sem a influência da opinião de um jornal, uma revista, um editor ou um cientista. (TEDC5) 
Este extrato aborda questões que consideramos importantes na aproximação entre a educação para as mídias e o ensino de ciências. Em primeiro lugar, enfatiza a importância de os próprios alunos desenvolverem suas visões de mundo, a partir de uma gama de fontes, tanto da mídia quanto da ciência. Além disso, enfatiza que a compreensão dos materiais de mídia passa por compreender as mensagens subentendidas que as compõem.

Outro indício de busca por problematização tanto da mídia quanto da ciência encontra-se na descrição do desenvolvimento do que seria a aula 2 do grupo 5, na qual propõem alguns questionamentos como estruturantes da aula 3:

Ao final da aula [2], para pesquisa a ser aprofundada em debate na Aula 3, devem-se levantar seguintes perguntas:

- Como eu sei que o que estou lendo é verdadeiro?

- Como saber se a fonte da minha pesquisa é confiável?

- Como é o trabalho do cientista?(TEDC5)

\section{Problematização da Mídia}

O grupo 3 indica como objetivos o desenvolvimento de posturas críticas diante da mídia. É possível inferir que os licenciandos compreendem que a apropriação de conhecimentos científicos é condição para a possibilidade de desenvolvimento de crítica aos materiais de mídia.

O objetivo dessas aulas será mostrar aos alunos que nem sempre o que está em uma mídia famosa é uma verdade absoluta, será importante nessas aulas que os alunos desenvolvam conhecimento sobre o assunto para que possam questionar informações cedidas pelo texto (TEDC3)

O entendimento de que apreender conhecimento científico é condição para a crítica da mídia fica ainda mais evidenciado na descrição da primeira aula, em uma sequência de quatro aulas, que propuseram em seu plano de aula. 
Procurar instigar os alunos quanto ao conteúdo apresentado nos textos jornalísticos, a fim de procurar possíveis falhas nesses textos. Também procurar as raízes dessas pesquisas, para começar nas próximas aulas, a construir os caminhos que levaram até elas (TEDC3).

\section{Problematização da Ciência}

O grupo 5, embora tenha proposto a problematização da mídia, destacando entre outras coisas a leitura das "entrelinhas" das produções midiáticas e de questionamentos sobre a dinâmica de produção da mídia, foca sobretudo na problematização da própria ciência.

A proposta complementa um planejamento de 3 aulas com o objetivo unir o cronograma de aulas relacionado ao campo da termologia e desmistificar o pré-conceito inserido nos alunos em relação ao engrenamento da educação científica. A previsão é de que o aluno adquira visão fora do senso comum sobre o funcionamento e a construção da ciência a partir dos objetivos gerais e específicos ofertados nesse planejamento (TEDC5)

$\mathrm{Na}$ descrição das aulas fica ainda mais claro a pretensão de desenvolver posturas críticas com relação à prática científica.

[...] a pretensão é utilizar textos jornalísticos relacionados ao Climategate, de ambos os pontos de vista, para quebrar o senso comum do cientista como ser perfeito. A partir disso, o aluno se questionará sobre todo o conhecimento que lhe foi passado de forma crítica, aprofundando suas pesquisas e elaborando mais perguntas (TEDC5)

O grupo 4 também prioriza a problematização da ciência, em particular ao enfatizar o caráter construtivo e histórico deste conhecimento.

O objetivo de esclarecer o tecido espaço-tempo aos alunos é para mostrá-los que, na física, existem diversas teorias que tentam explicar 
o mesmo fenômeno; que não há somente uma teoria que é a "verdade absoluta" e que explica exatamente tudo o que ocorre. Neste caso, o conceito do tecido espaço-tempo serve como uma alternativa ao modelo gravitacional de Newton, que é o modelo mais comumente ensinado em escolas de ensino médio. (TEDC4)

\section{Ausência de problematizações}

O grupo 1 apresentou seu plano de aula sem indícios de problematizações, tanto da ciência quanto da mídia. De maneira geral, propuseram como objetivos a explicação sobre energia renovável e não renovável e os conceitos de fissão e fusão nucleares. Apresentaram seus objetivos da seguinte maneira:

- $\quad$ Explanar sobre Energia não renovável; Energia Nuclear

- Explorar didaticamente os conceitos de fissão e fusão da energia nuclear

- Aplicação: Civil (Geração de Energia -Usinas Atômicas) e Militar (Bomba Atômica)

- $\quad$ Acidentes Nucleares, causas: Naturais (Fukushima - Tsunami em março/2011) e Humanas (Chernobyl - Teste mal sucedido em abril(1986). (TEDC1)

\section{Relação Professor-Conhecimento-Aluno}

\section{Relação expositiva}

A análise de nosso corpus indicou que a maior parte dos grupos planejou suas aulas de modo que os alunos fossem colocados em posições passivas, os quais teriam a função de compreenderem as relações que são objetivadas a partir, principalmente, de aulas expositivas.

Expor que, partindo do estudo de natureza da ciência, é possível interligar áreas diferentes de aprendizado (física, química e biologia), pois são necessárias para temas distintos. (TEDC2) 
Explicar o intuito do foco das agências espaciais (NASA, ESO e CNSA) na construção de sondas para pesquisa em satélites naturais que possivelmente que carregam chances de abrigar condições para desenvolvimento de vida.

Explicar também as variáveis que são necessárias serem estudadas para o lançamento da sonda no satélite específico da pesquisa, bem como os problemas que podem surgir durante o lançamento/trajeto da sonda. (TEDC2)

\section{Explicar em aula expositiva o conteúdo das reportagens em três} blocos: Acidentes Nucleares, Bomba Atômica e Princípios de "Fissão" e "Fusão Nuclear", explanando sobre os principais aspectos dos fatos e fenômenos. (TEDC1)

\section{Seleção de conhecimentos Científicos}

A partir da análise de nosso corpus é possível verificar que os licenciandos propuseram temas que normalmente não figuram em currículos tradicionais de física. Houve, sobretudo, uma predileção por temas atuais que envolvessem a física, tais como energia nuclear, questões climáticas, ondas gravitacionais e o lançamento de sondas espaciais. Esta perspectiva de selecionar temas atuais como forma de superar, ao menos em partes, o ensino tradicional foi, em alguns casos, consciente.

Fugir, de maneira provisória, da repetição de fórmulas e da matemática ensinada em ensino médio, que muitas vezes são completamente abstratas e de difícil compreensão para os alunos, a fim de trazê-los a uma área mais recente da Física que geralmente não é passada nas escolas (TEDC4).

Entendemos que inserir a mídia no ensino de física permitiu aos licenciandos selecionar conhecimentos, tradicionais ou contemporâneos, que não tinham fim em si mesmos. Isto é, a inserção da mídia permitiu a proposição de aulas nas quais o conhecimento físico é apresentado de forma 
contextualizada, embora nem sempre esses contextos tenham sido problematizados, como destacamos acima.

\section{Seleção de conteúdos científicos tradicionais contextualizados}

Dos cinco grupos, apenas o grupo 5 selecionou conhecimentos que consideramos tradicionais, isto é, conhecimentos físicos que normalmente figuram nos currículos escolares. Para discutirem o caso do climategate, os licenciandos propuseram uma primeira aula para discutirem termologia, em particular sobre escalas termométricas e diferenciação entre temperatura e calor.

Aula 1: segmento do cronograma escolar sobre Termologia, reforçando as escalas termométricas, diferenciação de temperatura e calor e operação com transformações entre diferentes escalas de temperatura. (TEDC5)

Vale notar, contudo, que a seleção de conhecimentos não se restringe aos conteúdos e teorias científicas, mas conta também com conhecimentos acerca do fazer científico. Isto é, ensinar/aprender ciência é mais do que apenas dominar os conteúdos científicos em si. Neste sentido, o grupo 5 selecionou, além de conteúdos de termologia, conhecimentos sobre $\mathrm{NdC}$, com o objetivo de problematizar o fazer científico a partir do caso climategate.

Aula 3: Problematizar da imagem estereotipada do fazer científico, adentrar a sala de aula num aprofundamento sobre a função e dever do cientista, incentivando-os as áreas relacionadas e desenvolvendo o senso crítico na leitura do aluno (TEDC5).

\section{Seleção de conteúdos científicos não tradicionais}

Os grupos 1, 2, 3 e 4 selecionaram conteúdos que consideramos como não tradicionais, isto é, que normalmente não figuram nos currículos de física. $\mathrm{O}$ grupo 1 selecionou episódios relacionados à energia nuclear, tema ligado à física moderna e que já vem sendo indicado por pesquisadores e por currículos há pelo menos duas décadas. O grupo 2 selecionou um tema interdisciplinar, no qual o foco principal são os estudos sobre a possibilidade 
de vida extraterreste. Este tema inclui conhecimentos de Física, Biologia e Química, além de conhecimentos atrelados ao desenvolvimento tecnológico na construção de sondas espaciais.

$A$ visão de muitos alunos do ensino médio é que cada matéria da ciência age de forma individualizada. Porém, todas se complementam. Portanto, o objetivo é abordar a interdisciplinaridade no conhecimento científico com foco no envio de sondas para descobertas espaciais. (TEDC2)

Além de ser um tema interdisciplinar, podemos considerar que se trata de conhecimentos contemporâneos que figuram entre as discussões de parte dos cientistas atuais e, ainda, o tema de vida extraterrestre figura no imaginário popular.

Os grupos 3 e 4 selecionaram o tema das ondas gravitacionais. Embora seja uma temática na qual a contextualização é feita a partir da própria dinâmica de funcionamento da ciência, principalmente relacionada ao papel do experimento na construção da física, traz um grande apelo popular, principalmente por representar uma extensa história entre a proposição teórica das ondas gravitacionais, a construção de grandes e precisos equipamentos de medida com alto grau de investimento e participação multinacional, até, enfim, a confirmação/corroboração da previsão teórica. Além disso, o tema trata diretamente de uma contribuição de Einstein, considerado como uma das mais icônicas figuras da física e da ciência como um todo.

O grupo 4 valoriza explicitamente a abordagem de um tema recente da física em seu plano de aula.

A proposta de aula será composta por duas aulas cujo objetivo é tratar de um tema recente na área da Física, com a intenção de fugir do padrão de aula formal de apenas reprodução de fórmulas (TEDC4). 
Nos materiais que compõem nosso corpus não fica claro quais metodologias seriam empreendidas para a inserção dos materiais de mídia durante as aulas de física. Temos apenas indícios genéricos sobre tais inserções:

a pretensão é utilizar textos jornalísticos relacionados ao Climategate, de ambos os pontos de vista, para quebrar o senso comum do cientista como ser perfeito (TEDC5)

Em geral, nosso corpus indica que os licenciandos apresentaram preferência por inserir os materiais midiáticos após uma sequência de aulas que introduzissem determinados temas.

Explicar em aula expositiva o conteúdo das reportagens em três blocos: Acidentes Nucleares, Bomba Atômica e Princípios de "Fissão" e "Fusão Nuclear", explanando sobre os principais aspectos dos fatos e fenômenos (TEDC1)

Nesta aula, depois que os conceitos necessários para entender o que são ondas gravitacionais foram apresentados, depois que foram construídas todas as bases para se chegar nesse conceito contemporâneo do universo, os alunos estarão preparados para criticar e avaliar o conteúdo apresentado nos textos, além de saber também quais são os objetivos do meio midiático que apresentou o trabalho. (TPE4)

Por fim, as notícias serão dadas para os alunos interpretarem $e$ discutirem entre si, conforme o que foi passado em aula até o momento. (TEDC2)

A maneira mais recorrente de avaliar os alunos e proporem que desenvolvam atividades foi através da produção de textos.

Como meio avaliativo será cobrado uma redação dissertativoargumentativa em que será introduzido o assunto abordado na 
notícia, bem como uma solução básica para os problemas enfrentados. (TEDC2)

Para avaliar os alunos, será proposto que eles escrevam um texto criticando os pontos positivos e negativos dos textos jornalísticos que eles leram na primeira aula, mostrando brevemente os caminhos que levaram a essas pesquisas e demonstrando o que eles entenderam sobre ondas gravitacionais. (TEDC3)

Como forma de avaliação, será proposto uma resenha escrita para os alunos para verificar se os objetivos pretendidos em aula foram atendidos (TEDC4)

O resultado que consideramos mais importante deste eixo de análise foi que os licenciandos tiveram dificuldades em propor planos de aulas que fossem coerentes com a análise que empreenderam dos materiais selecionados. Em geral, propuseram aulas que priorizavam exposições e com avaliações que também não enfatizaram possíveis contribuições criativas dos alunos. Vale destacar que EDC é a primeira disciplina de ensino que os alunos têm contato em seu currículo da licenciatura em física.

\subsubsection{Interpretações a partir das categorizações: construindo um metatexto}

Uma das compreensões a que chegamos ao desmontar os textos dos licenciandos em unidades de análise e categorizá-los foi que houve pouca confrontação entre os materiais de diferentes meios de comunicação que selecionaram. Em paralelo à dificuldade em confrontar os materiais midiáticos, entendemos que houve descrições pobres dos meios de comunicação dos quais foram selecionados os materiais analisados pelos grupos. Em geral, os grupos se limitaram a apresentar o título das reportagens selecionadas e onde foram publicadas. Pouca ou nenhuma atenção foi dada às datas de publicação, se as reportagens eram assinadas por uma pessoa ou pela redação, se o canal de comunicação era público ou privado, se faziam parte de grandes conglomerados, etc. Como nos chama 
atenção Paulo Freire e a literatura em educação para as mídias, as produções midiáticas não são neutras e sim tributárias de seus contextos de produção. Caracterizar minimamente os meios de comunicação é condição indispensável para compreendermos as construções de argumentos, as defesas de pontos de vista, etc. Além disso, entender os possíveis usos de poder passa por identificar os lugares de fala, os eventuais interesses políticos e econômicos de quem produz as mensagens que circulam na mídia, o que foi pouco explorado pelos grupos em geral.

Nossa análise indica, também, que os licenciandos produziram análises que problematizaram algumas características relacionadas à produção da mídia. Por exemplo, os licenciandos indicaram em suas análises o uso de discursos indiretos como forma de usar a autoridade do cientista nos discursos produzidos pela mídia. Este recurso linguístico/discursivo é amplamente usado pela mídia na construção de suas narrativas. Fala-se através dos especialistas. É comum usar discursos indiretos na construção de enunciações. Como afirma Zamboni (2001), a enunciação do discurso científico aparece recorrentemente "sob a forma do discurso indireto Fulano diz que..., em que o nome dos enunciadores, seu estatuto de especialistas e o tempo de enunciação são especificados com abundância e rigor" (ZAMBONI, 2001, p.52). A autora defende que o uso desse discurso indireto dos cientistas empresta ao discurso da divulgação científica, e da mídia no nosso caso específico, um “'efeito de real' do discurso da ciência, ao mesmo tempo em que lhe assegura a autoridade e a seriedade da voz que 'diz a verdade"'(idem).

Além do uso de discursos indiretos pela mídia, o principal apontamento dos licenciandos é que a mídia sobre ciência produz simplificações da linguagem da ciência. Um dos grandes desafios dos jornalistas, particularmente para àqueles que produzem materiais sobre ciência, é lidar com a construção de um discurso para o público amplo a partir de um discurso especializado. Como salientamos nos capítulos anteriores, a tarefa do jornalista, e do divulgador da ciência de maneira 
geral, não se restringe a uma mera tradução, mas passa por uma reinterpretação entre discursos. Este processo, contudo, pode levar a simplificações demasiadas, como indicaram os licenciandos.

A simplificação foi uma das características mais apontadas pelos licenciandos em nosso corpus. Interpretamos que isso se deve ao próprio contexto em que estão inseridos esses professores em formação. Como alunos de segundo semestre em um curso de licenciatura em física, a expectativa é que suas formações devem estar relacionadas a uma apropriação profunda, e não simplificada, do conhecimento físico. O que, embora não seja suficiente, julgamos ser fundamental.

Com relação à aproximação entre as perspectivas da mídia e do ensino de ciências, a análise de nosso corpus nos levou a interpretar que a própria seleção dos temas empreendida pelos grupos teve como critério os impactos sociais, tecnológicos e ambientais relacionados à ciência. Esta busca por aproximar a ciência de questões com relevância social é uma característica da própria mídia, que busca sempre a maior audiência possível e, portanto, produz seus materiais de modo que tenham impacto sobre os possíveis leitores, telespectadores, ouvintes etc.

Como a mídia normalmente aborda assuntos contemporâneos e com apelo aos interesses de um público amplo, verificamos que os temas e conhecimentos propostos nos planos de aulas dos licenciandos de EDC normalmente não figuram em currículos tradicionais de física. Houve, sobretudo, uma predileção por temas atuais que envolvessem a física, tais como energia nuclear, questões climáticas, ondas gravitacionais e o lançamento de sondas espaciais.

Entendemos que inserir a mídia no ensino de física permitiu aos licenciandos selecionar conhecimentos, tradicionais ou contemporâneos, que não tinham fim em si mesmos. Isto é, a inserção da mídia permitiu a proposição de aulas nas quais o conhecimento físico é apresentado de forma contextualizada. Além disso, nossa análise indica que a forma como a mídia 
aborda a ciência possibilita problematizações sobre a própria produção da ciência. Os licenciandos destacaram, entre outros aspectos, a forma como a mídia trata o papel dos experimentos na construção do conhecimento, o mito do gênio, questões sobre o financiamento da ciência, questões controversas como o vazamento de emails sugerindo a manipulação de dados por parte de cientistas etc. Discutir questões sobre a ciência vem sendo indicado nas pesquisas atuais em ensino de ciências, sobretudo como forma de formar cidadãos e cidadãs que sejam aptos a compreenderem a dinâmica da ciência, em busca de posturas críticas em momentos de decisões, pessoais ou coletivas.

Por fim, destacamos que o conjunto de dados que compõe nosso corpus indicou que embora os licenciandos tenham desenvolvido críticas bem elaboradas tanto da mídia quanto da ciência, não conseguiram concretizar em seus planos de aula situações em que houvessem problematizações tanto da mídia quanto da ciência. Além disso, em geral os grupos desconsideraram as capacidades criticas e criativas dos alunos que eventualmente seriam impactados pelos planos de aulas desenvolvidos. Houve uma predileção por uma relação professor-conhecimento-aluno unidirecional, do professor para o aluno, em abordagens expositivas do conhecimento científico e das críticas à mídia. Interpretamos isto como uma tensão normal pela qual licenciandos em início de curso devem ser submetidos, já que grande parte tem introjetados em si uma cultura escolar que prioriza o professor como detentor de conhecimento e o aluno como tabula rasa que deve ser preenchido e moldado.

\subsection{Produções dos licenciandos da disciplina "Oficina de Projetos de Ensino 1"}

Assim como fizemos com os materiais de EDC, apresentaremos os materiais midiáticos selecionados pelos licenciandos de PE. Vale destacar que os trabalhos nesta disciplina foram desenvolvidos individualmente e envolveram estágio supervisionado. Dentre as atividades desenvolvidas no estágio, os licenciandos propuseram e realizaram regências envolvendo a 
inserção da mídia em aulas de física. Os registros dessas regências, tanto escritos como em gravações de seminários, compõem nosso corpus de análise.

\subsubsection{Materiais midiáticos selecionados pelos licenciandos de PE1}

O licenciando PE1 desenvolveu seu estágio em escola pública estadual, aplicando sua regência a uma turma do $3^{\circ}$ ano do ensino médio. Selecionou o tema "acelerador de partículas Sirius", que havia sido recém inaugurado. De acordo com o licenciando, a seleção do tema se deu, justamente, pelo timing da notícia.

Ele teve a inauguração dia 14/10. Então, fazia pouquíssimo tempo. Eu tava apostando que, sei lá, que apareceu no twiter deles, eu tava torcendo para que eles tivessem tropeçado nessa notícia. Das 5 turmas que eu acompanhei, em 3 tiveram alunos que viram essa notícia. Então foi legal falar de algo bem recente. (VPE1)

Durante sua regência usou trechos selecionados dos seguintes materiais: artigos "Mesmo com cortes, acelerador de partículas Sirius avança nas obras ${ }^{4 \mathcal{S}}$ ' da Revista Galileu em 13/12/2017 por Thiago Tanji e "Sirius: novo acelerador de partículas brasileiro é inaugurado em Campinas $^{49}$ ' do Portal TECMUNDO em 14/11/2018 por Leonardo Müller.

A matéria da Galileu, assinada por Thiago Tanji, é iniciada com uma foto do lado interno do acelerador de partículas Sirius, na qual podemos ver operários trabalhando na obra inacabada. A primeira afirmação de Tanji é que a "ciência brasileira sofre diante dos seguidos cortes de investimentos do governo federal". Afirma que se contássemos nossa história como capítulos de Star Wars, estaríamos na parte em que os Jedi lutam para não serem destruídos. Tanji coloca a construção do Sirius, aos trancos e barrancos, como uma esperança para a ciência brasileira.

\footnotetext{
${ }^{48}$ Disponível em: https://revistagalileu.globo.com/Ciencia/noticia/2017/12/mesmo-com-cortesacelerador-de-particulas-sirius-avanca-nas-obras.html.

${ }^{49}$ Disponível em: https://www.tecmundo.com.br/ciencia/136220-sirius-novo-acelerador-particulasbrasileiro-inaugurado-campinas.htm.
} 
Tanji afirma que quando estiver funcionando, o Sirius será o equipamento mais avançado do mundo na geração de luz síncroton. Ainda que este acelerador coloque o Brasil em um "patamar de fronteira", como afirmou o diretor do Laboratório Nacional de Luz Síncroton, Antônio José Roque, à Revista Galileu, a construção deste empreendimento científico esbarra em cortes de investimentos do governo, em uma obra ao custo de mais de $R \$ 1.5$ bilhão. A matéria afirma que o projeto fora lançado sob o governo de Luís Inácio Lula da Silva, em 2007, e que as reduções orçamentárias de Michel Temer impactaram diretamente nas obras do acelerador de partículas. Roque afirma, ainda à Galileu, que "em poucos anos você consegue destruir tudo isso: construir é muito difícil, destruir é muito mais fácil. E por isso esse é um momento extremamente preocupante."

A matéria da Galileu enfatiza a precisão dos equipamentos que compõem o acelerador e como isto poderá ser usado para pesquisas científicas. Tanji afirma que a precisão e a capacidade tecnológica são tantas que será possível, por exemplo, realizar a tomografia de células e vasculhar o DNA do interior de seu núcleo, em uma projeção realizada em três dimensões.

Por fim a matéria da Galileu apresenta na íntegra a entrevista feita com o diretor do Laboratório Nacional de Luz Síncroton, Antônio José Roque. Dentre as perguntas, ele comentou sobre sua avaliação das obras em 2017 e suas expectativas para o ano de 2018. Além disso, comentou sobre qual tipo de ciência poderia ser produzida com o acelerador Sirius, afirmando que "é uma ferramenta pensada para prover para a comunidade brasileira o que há de mais competitivo em um conjunto amplo de técnicas". Sobre a importância e os impactos para a ciência brasileira, Roque afirma que "um dos legados que um projeto como o Sirius deixa é que, sim, é possível fazer projetos nessa escala, com mão de obra brasileira e com jovens das mais variadas áreas". Tanji questiona Roque sobre a preocupação que a comunidade científica estava mostrando pelos cortes de investimentos por 
parte do governo federal. Roque comenta que com os cortes orçamentários, algumas obras foram priorizadas, dentre elas a dos Sirius, devido seu estágio avançado de construção. Por fim, Roque comenta sobre os possíveis desdobramentos tecnológicos do Sirius, apontando pesquisas em exploração de petróleo, na agricultura, na saúde, em biologia celular etc.

O texto publicado no site "TecMundo", assinado por Léo Muller, versa sobre a inauguração do acelerador Sirius em Campinas. A matéria é iniciada com uma foto na qual é possível ver o empreendimento científico por cima: Um grande prédio em formato circular com seis "extensões" saindo em pontos diferentes deste círculo. O texto começa afirmando que fora inaugurada a primeira fase do acelerador de partículas, que quando concluído será a mais avançada fonte de luz síncroton do mundo. Ao total, o Sirius deverá custar $\mathrm{R} \$ 1,8$ bilhão, sendo que já haviam sido investidos $\mathrm{R} \$$ 1,3 no momento em que Muller produziu seu texto. A expectativa é que esteja funcionando 100\% em 2021, afirma a matéria do TecMundo. A matéria destaca, ainda, que $85 \%$ de toda tecnologia utilizada foi obtida diretamente no Brasil.

De acordo com Muller, o coordenador do projeto Sirius, Antônio José Roque - diretor-geral do Centro Nacional de Pesquisa em Energia e Materiais -, diz que o Sirius será um laboratório aberto aos pesquisadores. Um dos objetivos centrais do acelerador, contudo, será aperfeiçoar pesquisas na produção de petróleo e gás. Por fim, Muller destaca que o então presidente da república, Michel Temer, esteve na inauguração e ressaltou que o laboratório é a maior e mais avançada base de pesquisa científica já construída no país e que permitirá a integração entre os pesquisadores locais e os de várias outras partes do mundo.

O licenciando PE2 fez seu estágio em escola privada, tendo realizado sua regência também no $3^{\circ}$ ano do ensino médio. Sua regência abordou tema "relatividade", focando no paradoxo dos gêmeos. O licenciando selecionou dois materiais relacionados ao tema, um do site de notícias G1 e outro da revista de divulgação científica Scientific American. O licenciando não 
apresenta, tanto em seu relatório quanto no seminário, quais foram as matérias especificamente. O principal objetivo declarado pelo licenciando foi problematizar a maneira como a imagem de Einstein era veiculada por cada uma dessas produções selecionadas.

[...] comecei a ler uma parte que eles [G1] falavam que "quando Einstein desenvolveu a teoria da relatividade geral ele teve a brilhante ideia de não sei o que..." aí eu perguntei para eles assim: isso daqui não traz um desconforto pra vocês? Aí eles: não!. Aí eu disse: pois devia trazer, porque eles tratam o cara como um gênio. Aí muitos disseram: ah, mas ele não é um gênio? Aí é que está o problema, não é só porque ele é um cientista, que trabalha com isto, que ele é um gênio. Aí comecei a problematizar essa ideia de que a ciência é linear e que acontece sem nenhum erro, e que as coisas acontecem cronologicamente uma em seguida da outra, tudo certinho, que é uma visão muito errada que a gente tem de ciência, assim como endeusar os cientistas (VPE2).

O licenciando PE3 realizou seu estágio no próprio Instituto Federal de São Paulo, onde é estudante de licenciatura. Acompanhou turmas de $1^{\circ}$ ano do ensino médio integrado ao técnico em informática. Em negociação com o Professor que a recebeu, selecionou o tema "Ilhas de Calor". PE3 selecionou duas reportagens: Calor Urbano ${ }^{50}$, publicado em $1^{\circ}$ de novembro de 1998 na Folha de SP, assinado por Marcelo Ferroni; e a reportagem Como as grandes obras verticais estão criando ilhas de calor em Brasília?51, publicada em 28/01/2018 no jornal Correio Braziliense e assinado por Walder Galvão.

O objetivo declarado por PE3 foi o de explicar as causas do fenômeno de ilhas de calor a partir dos materiais selecionados.

\footnotetext{
${ }^{50}$ Disponível em: https://www1.folha.uol.com.br/fsp/ciencia/fe01119802.htm.

${ }^{51}$ Disponível em:

https://www.correiobraziliense.com.br/app/noticia/cidades/2018/01/28/interna_cidadesdf,656221/co mo-as-grandes-obras-verticais-estao-criando-ilhas-de-calor-no-df.shtml.
} 
Eu usei a mídia mais para trazer esses problemas. O jornal não tenta explicar as causas do fenômeno. Então falei, ah...vou pegar ele mas não cita conceito assim direitinho. Ele só vai falar porque acontece: as cidades revestidas de concreto, de asfalto, etc. e isso influencia, ponto. Não falam o "porquê"(VPE3).

A reportagem da Folha de SP, publicada em novembro de 1998 e assinada por Marcelo Ferroni, é iniciada com uma imagem termal da área da cidade de Sacramento, na Califórnia (EUA). A foto é atribuída à NASA e mostra, em vermelho, pontos mais quentes da cidade. Este tipo de imagem, de acordo com a reportagem, é usada no desenvolvimento de projetos para "esfriar" as cidades. Ferroni explica que as fotos são obtidas por câmeras termais acopladas a aviões, e que vêm sendo usadas pelo centro de Voos Espaciais Marchall, da NASA. As regiões mais quentes, indicadas pelas cores avermelhadas, são identificadas como "ilhas de calor", afirma a matéria. Continua, afirmando que a ilha de calor é equivalente a uma "bolha" de calor que envolve determinados trechos das cidades e que ocorre normalmente em locais em que a superfície natural foi substituída por asfalto, concreto e outras construções humanas.

Até o momento em que a reportagem fora produzida, três cidades estadunidenses haviam sido mapeadas: Baton Rouge, em Louisiana, Sacramento, na Califórnia, e Salt Lake City, em Utah. As imagens indicam que as três cidades são muito quentes e que é necessário o aumento de áreas arborizadas e de telhados com materiais que reflitam a radiação solar. A reportagem da Folha de SP consultou, ainda, a pesquisadora em climatologia e qualidade ambiental urbana da USP (Universidade de São Paulo) e da Unesp (Universidade Estadual Paulista), Magda Lombardo, que afirmou que as ilhas de calor podem se tornar mais críticas devido a fatores ambientais, como a falta de ventos que além de aumentar o calor nessas regiões, favorece a concentração de poluição nesses locais. Lombardo estuda as ilhas de calor em São Paulo, que, ao lado da Cidade do México, é a cidade mais afetada pelo fenômeno, afirma a matéria. Ferroni afirma que áreas 
com muita biomassa -matéria de origem vegetal-, espelhos de água e materiais que dissipem o calor são algumas formas de combate às ilhas de calor. Por fim, destaca a fala de Lombardo que indica que o efeito das ilhas de calor tende a aumentar devido ao crescimento desordenado e à falta de planejamento na periferia da cidade de São Paulo.

A reportagem publicada pelo jornal Correio Brasiliense e assinada por Walder Galvão, também é iniciada com uma foto. Nesta foto é possível ver um conjunto de vegetação em um primeiro plano e ao fundo, uma série de edifícios. A legenda diz: "Verticalização das construções e pouca distância entre prédios podem aumentar temperatura em até $6^{\circ} \mathrm{C}$. A reportagem começa descrevendo o clima sob o qual os brasilienses vivem boa parte do ano: tempo seco, umidade baixa e calor. Contudo, continua Galvão, o que era para ser um fenômeno natural tem se agravado pelas áreas verticalizadas da cidade. A matéria afirma que o clima de Brasília deveria ser extremamente ameno, mas grandes construções do Distrito Federal geral Ilhas de Calor. De acordo com Galvão, estudos e especialistas apontam o aumento da temperatura nos Setores Bancários Sul e Norte e na região de Águas Claras. A variação pode ser de até $6^{\circ} \mathrm{C}$ e o calor permanece por mais tempo. A falta de vegetação e de planejamento são as principais causas desse problema. A afirmação é embasada em estudos dirigidos por Marta Bustos Romero, especialista em arquitetura e urbanismo e bioclimatismo da Universidade de Brasília (UnB). A reportagem destaca que, segundo a pesquisadora, os materiais urbanos, como concreto e pavimentação, têm capacidade diferente dos elementos naturais. "A luz do sol é refletida para a atmosfera, porém, esses elementos absorvem o calor e não devolvem instantaneamente. As superfícies ficam aquecidas e a temperatura só volta a ser redistribuída à noite”, esclarece Romero.

Como indicação de possíveis soluções, destacam a "morfologia urbana”. Em outras palavras, a altura e a distância entre os edifícios, bem como a inclusão de áreas com vegetação devem ser pensados para o desenvolvimento das cidades. Em seguida, Galvão discute os problemas de 
saúde causados pelas Ilhas de Calor, principalmente relacionados à doenças respiratórias. Por fim, discutem como o grande número de automóveis pode ter relação com o fenômeno das Ilhas de Calor. De acordo com a reportagem, Marta Romero explica que os automóveis parados também absorvem calor e causam um fenômeno parecido com o dos prédios. Por fim, destacam que o Instituto Brasília Ambiental (Ibram) informa que é realizado o monitoramento da temperatura em quatro estações meteorológicas, localizadas em diferentes localidades da região. A reportagem afirma que, de acordo com o analista ambiental e meteorologista do órgão, Carlos Henrique Rocha, com o auxílio da medição, a ideia é elaborar um planejamento para que haja intervenções nas ilhas de calor, como investir em arborização.

O licenciando PE4 desenvolveu seu estágio em escola pública estadual, aplicando sua regência em uma turma do $3^{\circ}$ ano do ensino médio. O tema selecionado foi "gato de luz". Segundo PE4, o tema surgiu a partir do livro didático usado pelos estudantes, que falava dessa temática na seção de eletromagnetismo. PE4 não deixa claro quais foram as intersecções de sua aula com os materiais de mídia selecionados. A única menção está relacionada à afirmação de que os materiais que selecionou não abordavam questões físicas e, também, que a maior parte dos materiais consultados implicavam à classe média os gatos de luz.

Os materiais que eu peguei falando de gato de luz, todos criticam o gato. Nenhum é a favor. Não falam, na verdade, da matéria da física, dos problemas que ele dá...assim, questões de tensão, resistência, corrente, amperagem...eles não falam nada. O que eles falam, na verdade, são que principalmente, no que eu li, que não são gatos de luz de periferias. A maioria dos que eu vi, na verdade, são de classe média, gente da alta que rouba energia elétrica. Não rouba energia elétrica da maneira que o pobre faz. A pessoa compra um medidor de luz. Vai lá nas configurações dele, quebra um lacre que ele tem, muda todas as configurações dele. Em vez de mandar ler lá tantos 
quilowatts gastos, está inferior. Então é um problema social muito grande.

O licenciando PE5 fez seu estágio no IFSP, onde cursa licenciatura em Física. Sua regência foi desenvolvida no $1^{\circ}$ ano do ensino médio integrado ao técnico em eletrotécnica. O tema da regência foi "choque térmico e bionergética". PE5 declarou ter selecionado este tema porque "eles [alunos] estavam vendo termodinâmica e porque eu achei interessante trabalhar com alguma coisa relacionada à saúde, que é um assunto que pouco se fala em física" (VPE5).

Sua aula teve como objetivo explorar a seguinte questão inicial: Qual a importância da temperatura para vida e para a manutenção dela? (TPE5). Selecionou três notícias relacionadas a mortes de pessoas devido a mudanças bruscas de temperatura. São elas: Homem morre de frio em Piraí do Sul52, publicada em 21 de junho de 2001 na Folha de Londrina; Embriagado, homem deita na calçada para dormir e morre durante madrugada em Curitiba ${ }^{53}$, publicada em 21 de junho de 2016 em um site de notícias intitulado "Banda B"; Homem morre após dormir com três ventiladores ligados ${ }^{54}$, publicado em 09 de novembro de 2017 pelo "Catraca Livre".

A reportagem da Folha de Londrina, assinada por Denise Angelo, é uma breve nota sobre o falecimento de um homem de 37 anos em decorrência do frio. De acordo com a matéria, os termômetros indicavam $1^{\circ} \mathrm{C}$ na madrugada em que o homem que morava em uma garagem faleceu. Por fim a breve nota chama atenção que o Serviço de Obras Sociais começara a fazer "arrastões" nos bairros da cidade para recolher doações de agasalhos.

\footnotetext{
${ }^{52}$ Disponivel em: https://www.folhadelondrina.com.br/cidades/homem-morre-de-frio-em-pirai-do-sul344393.html.

${ }^{53}$ Disponivel em: https://www.bandab.com.br/geral/embriagado-homem-deita-na-calcada-paradormir-e-morre-durante-madrugada-2/.

${ }^{54}$ Disponível em: https://catracalivre.com.br/entretenimento/homem-morre-apos-dormir-com-tresventiladores-ligados/.
} 
A notícia publicada pelo site Banda B, assinada por Elizangela Jubanski e Djalma Malaquias, é iniciada com uma foto de um cadáver coberto por um pano branco em uma área isolada e cercada por policiais militares. A primeira afirmação da reportagem é que um morador de rua alcoólatra foi encontrado morto em Curitiba. A causa de morte mais provável indicada pela reportagem foi em decorrência das baixas temperaturas na cidade paranaense, que chegou aos $5,1^{\circ} \mathrm{C}$ naquela madrugada. Por fim, relatam que a Polícia Científica foi acionada e o Instituto Médico Legal (IML) fará o recolhimento do corpo. Concluem dizendo que exames posteriores vão indicar se a vítima morreu em decorrência de hipotermia, quando o corpo baixa da temperatura de $35^{\circ} \mathrm{C}$.

A reportagem assinada pela redação do Catraca Livre é iniciada com uma foto de um quarto onde é possível identificar ao menos dois ventiladores ligados. A matéria afirma que um homem de 44 anos morreu na Tailândia de hipotermia após passar uma noite inteira com três ventiladores ligados. A pequena reportagem faz referência à publicação do site “Asia One”. A reportagem explica que, de acordo com o Asia One, é comum o clima mudar no período noturno na região em que o homem foi encontrado morto. Por fim, afirmam que com a aproximação do amanhecer, a temperatura estava muito baixa e o homem acabou sofrendo um choque térmico por não se adaptar bem ao frio intenso que se instaurou na casa.

PE5 considerou o uso dessas matérias apenas como uma problematização inicial.

Iniciei a regência com uma pergunta, né...aí parti para as notícias. Só que essas notícias eu usei...inicialmente eu pensei que ia usar como basilar da minha regência, mas eu pensando muito tempo, eu meio que descartei ela como se fosse a mídia principal. Então eu usei ela só como um gancho inicial (VPE5, grifo nosso).

O licenciando PE6 estagiou em escola pública estadual, realizando sua regência no $1^{\circ}$ ano do ensino médio. Selecionou o tema de "desastres 
naturais com vulcões". O tema surgiu, de acordo com PE6, a partir do interesse dos alunos ao verem o estagiário (PE6) estudando o livro "Decifrando a Terra". Os objetivos de PE6 estiveram relacionados à compreensão da dinâmica das camadas inferiores da Terra, o funcionamento e ação de vulcões (vulcanismo mundial), e essencialmente desenvolver a discussão a cerca da geopolítica e práticas governamentais ante os desastres naturais (TPE6). PE6 selecionou dois artigos jornalísticos que remontaram desastres naturais envolvendo vulcões ocorridos no início do século XX. Um deles envolvendo a erupção vulcânica de Quetzaltenango em 1902, na Guatemala, e o outro relacionado a erupção de Katmai em 1912 no Alasca, nos Estados Unidos.

O licenciando descreveu apenas um dos materiais utilizados: $U m$ desastre que Estrada Cabrera insistió em negar ${ }^{55}$, publicado pelo jornal da Guatemala "Prensa Libre" em 25 de outubro de 2016.

O subtítulo da matéria busca evidenciar as proporções do desastre natural ocorrido no início do século XX: "Há 115 anos se desencadeou na Guatemala uma das mais volumosas erupções vulcânicas ocorridas nos últimos séculos. Nos dias 24 e 25 de outubro de 1902 o Vulcão Santa María, em Quetzaltenango, entrou em erupção”. A matéria é assinada por Néstor Galicia e é iniciada com uma foto de Manuel Estrada Cabrera. A legenda afirma que Cabrera se manteve no poder entre os anos de 1898 e 1920.

A matéria começa indicando que uma câmera de magma foi esvaziada explosivamente em um terrível evento sem precedentes, devido ao dano e magnitude em várias cidades na parte ocidental do país. Afirmam que "a tremenda erupção" jogou durante vinte horas uma "incrível quantidade" de areia-pomes e poeira vulcânica (cinza), que subiu para o céu em uma coluna eruptiva de 30 quilômetros de altura. A escória vulcânica foi espalhada pelo vento sobre vastas extensões do oeste da Guatemala e Soconusco, em Chiapas, no México. A força da erupção foi tão grande, continua a matéria,

\footnotetext{
${ }^{55}$ Disponível em: https://www.prensalibre.com/hemeroteca/erupcion-del-volcan-santa-maria-en1902/.
} 
que era possível ouvi-la ao longe e que, devido ao barulho ter sido confundido com o som de detonações de bombas por consequência da desinformação nas principais cidades causada pelo próprio governo, havia rumores de que houvera um golpe de estado.

O ponto principal da reportagem é a indicação de que o governo negou a tragédia, principalmente porque a erupção ocorreu em um momento "inoportuno", afirma Prensa Libre, horas antes da inauguração das "Festas de Minerva". Afirmam, ainda, que durante meses os telegramas foram censurados ao exterior, para que não contivessem "mentiras", já que todas as publicações formais conhecidas da época sobre a erupção foram publicadas no exterior.

A tese de que houvera censura sobre a devastação em decorrência do desastre natural é reforçada por um boletim oficial da secretaria de relações exteriores do México, que indica as proporções catastróficas da erupção do vulcão Santa María. No dia seguinte ao desastre, a edição do "Diario de Centro América" foi publicada com uma enorme fotografia do presidente Estrada Cabrera, detalhando o programa completo das festividades de Minerva, sem dar um único parágrafo à erupção vulcânica. De acordo com a reportagem, apenas após as festividades o governo se pronunciou sobre o ocorrido, ainda assim subestimando seus desdobramentos.

A matéria é concluída indicando que até 1902, o vulcão Santa Maria fora vista com desdém por muitos geólogos nacionais e internacionais, porque, segundo eles, não representava um perigo real para Quetzaltenango e o resto do país, mas que, em outubro daquele ano, o vulcão provocou uma noite escura de vários dias. Além disso, o evento resultou na formação de outro vulcão na cratera Santa Maria, ainda mais perigoso: o Santiaguito.

O ponto central, para PE6, era problematizar como cada um dos governos, guatemalteca e estadunidense, lidou com os desastres, de acordo com as reportagens. 
[...] a primeira é um desastre de 1902 e a segunda de 1912. São 10 anos de diferença. Eu tive esse cuidado de escolher épocas próximas, para tentar comparar o que eu queria. (VPE6).

Após a leitura de ambos os artigos eu perguntei - $O$ que podemos observar ao comparar as situações das duas matérias? E o fiz para verificar se a turma estava alinhada com a ideia sobre as importâncias das ações governamentais para desastres naturais, quaisquer que eles sejam. (TPE6)

O licenciando PE7 estagiou no próprio IFSP, onde atua como aluno da licenciatura em Física, realizando sua regência em uma turma de $2^{\circ}$ ano do ensino médio integrado ao técnico. De acordo com PE7, o tema, atrito, foi proposto pelo Professor que o recebeu. Ele atendeu à solicitação do Professor e buscou uma abordagem que fosse, em sua visão, interdisciplinar:

[...] durante o estágio foquei minha sequência didática no tópico de atrito fazendo ligações com a biologia, assim, busquei noticias relacionadas ao termo atrito chegando à uma noticia do portal Terra falando sobre uma camisinha auto-lubrificante que protege o corpo do atrito por muito mais tempo do que o lubrificante íntimo (TPE7).

O licenciando selecionou três reportagens sobre a tal produção de camisinhas autolubrificantes: Cientistas criam camisinha autolubrificante ${ }^{56}$, publicado no site "Terra" em 18 de outubro de 2018; A camisinha que se autolubrifica e pode reduzir contágio por doenças sexualmente transmissíveis $^{57}$ publicada pela BBC em 18 de outubro de 2018; e uma replicação da reportagem da $\mathrm{BBC}$ no site $\mathrm{G} 1{ }^{58}$, publicada no mesmo dia.

A reportagem assinada pela redação do site Terra é iniciada com a afirmação de que a camisinha é o preservativo mais seguro que existe. Além de prevenir gravidez indesejada, ela também diminui a transmissão de

\footnotetext{
${ }^{56}$ Disponível em: https://www.terra.com.br/vida-e-estilo/minha-vida/cientistas-criam-camisinhaautolubrificante,99d034e5ad18de2037447e0e1fa809fc3zkex6i5.html.

${ }^{57}$ Disponivel em: https://www.bbc.com/portuguese/brasil-45903646.

${ }^{58}$ Disponível em: https://g1.globo.com/bemestar/noticia/2018/10/18/a-camisinha-que-se-autolubrificae-pode-reduzir-contagio-por-doencas-sexualmente-transmissiveis.ghtml.
} 
doenças sexualmente transmissíveis. No entanto, indica a matéria, muitas pessoas ainda resistem a usá-las na hora do sexo, por considerar que diminui o prazer. Pensando nisso, cientistas norteamericanos desenvolveram uma camisinha auto-lubrificante, que promete ficar mais escorregadia à medida que entra em contato com fluidos corporais.

$\mathrm{Na}$ sequência da matéria passam a explicar o desenvolvimento do preservativo, indicando como principal característica desta camisinha uma fina camada de polímeros hidrifílicos. De acordo com a reportagem, Esses polímeros são atraídos por moléculas de água e são solúveis. Assim, ao contato com uma superfície úmida, tornam-se escorregadios ao toque. É indicado que os testes feitos com essa nova camisinha mostram que seus "coeficiente de fricção" é 53\% menor se comparado com "camisinhas normais". Concluem a matéria afirmando que a camisinha foi desenvolvida por cientistas da Universidade de Boston e que, além do prazer relatado ser maior, o preservativo pode diminuir a infecção por infecções sexualmente transmissíveis, já que quanto mais lubrificada, menor a chance de rompimento por atrito. Por fim apresentam alguns tópicos sobre como usar a camisinha de maneira adequada.

A reportagem da BBC assinada por Michelle Roberts, e replicada pela Globo, é iniciada com uma imagem de várias camisinhas, com legenda que diz que novo preservativo desliza melhor ao entrar em contato com fluidos corporais e é capaz de manter a textura por pelo menos mil movimentos de penetração. A primeira afirmação de Roberts é com relação aos objetivos da pesquisa: de acordo com ela, os cientistas desenvolveram a camisinha autolubrificante como forma de estimular o preservativo no ato sexual. Em seguida a matéria afirma que embora seja um bom método contraceptivo e ser eficaz na proteção contra doenças sexualmente transmissível, nem todos gostam de usar a camisinha. A reportagem diz que em artigo publicado na revista acadêmica Royal Society Open Science, os autores dizem que esses problemas seriam resolvidos com o novo produto, já que ele desliza melhor depois de entrar em contato com fluidos corporais. A BBC realça, ainda, que 
o desenvolvimento da camisinha foi patrocinado pela Melinda Gates Foundation, dedicada a pesquisas na área da saúde.

A matéria enfatiza que os cientistas dizem que mais testes serão necessários para comparar o desempenho da camisinha auto lubrificante na "vida real" e que uma empresa ligada à Universidade de Boston planeja desenvolver o produto para venda comercial, mediante aprovação regulatória. Por fim indicam alguns erros comuns no uso de camisinhas, como usar produtos à base de óleo que podem danificar o látex, a reutilização de camisinhas, o mal condicionamento ao guardá-las etc.

O licenciando PE8 fez seu estágio no IFSP, desenvolvendo a regência no $1^{\circ}$ ano do ensino médio integrado ao técnico em informática. Selecionou o tema entropia, justificando a escolha tanto porque os estudantes estavam estudando isto à época de sua regência, quanto pela dificuldade, de acordo com a leitura de PE8, que normalmente os alunos apresentam acerca deste conceito físico.

PE8 propôs sua regência a partir de um problema apresentado pelo Professor na aula anterior:

"Após o big bang a Terra era uma massa viscosa, quente e com o tempo foi resfriando até endurecer e formar a crosta. Isso significa que a Terra antes tinha mobilidade, tinha uma temperatura maior e depois resfriou e solidificou. Ou seja, ou a teoria do big bang está errada ou a segunda lei da termodinâmica está errada porque se esfriou e solidificou, diminuiu a entropia"(VPE8).

PE8 buscou aproximações desta questão ao cozimento de um ovo. Para PE8, a busca por inserir a cozinha em aulas de física está relacionada à afetividade, o que, para ela, influencia diretamente na compreensão dos estudantes.

Para você explicar conteúdos que você quer explicar para o aluno, tem que fazer coisas que façam sentido para ele, que tenha alguma coisa relacionada ou à vivencia dele ou ao repertório histórico deles. Aí eu 
tenho usado sempre a cozinha. Eu acho importante sempre fazer uma ligação afetiva que a gente tem. A memória afetiva ajuda na compreensão e no envolvimento dos alunos. [...] Em escolas públicas normalmente são pessoas mais pobres, que moram em casas com dois cômodos: quarto e cozinha. Então fazem lição de casa na mesa da cozinha. O lugar que eles estudam é na cozinha. O lugar da vivência é a cozinha, porque às vezes não tem sala. Então é um ambiente que se eu consigo trazer a memória afetiva de amparo, carinho, na hora da aula, eu sinto sempre que rola uma relação. (VPE8).

Assim, os objetivos de PE8 foram, além de retomar a questão do Professor e relacioná-la ao cozimento do ovo, problematizar alguns materiais jornalísticos selecionados:

[...] retomar o exercício da aula anterior; relacionar a comparação do resfriamento da Terra após o big bang e o cozimento do ovo; e questionar os textos das reportagens do ponto de vista científico. Então, uma análise crítica dos recortes (VPE8).

PE8 selecionou uma reportagem da $\mathrm{BBC}$ e uma matéria da revista Galileu: Por que o tempo só anda para frente?59 Publicado em 2 de julho de 2015 pela BBC; Ciência da Criação: estudiosos brasileiros contestam o Big Bang e a Teoria da Evolução e propõem que o universo foi planejado60, publicado na edição $\mathrm{n}^{\circ} 187$ da revista Galileu, publicada em fevereiro de 2003 e assinada por Pablo Nogueira.

A reportagem da BBC, assinada por Adam Becker, é iniciada com uma imagem desconfigurada de um relógio. Na legenda, a afirmação de que cientistas explicam que é preciso ver o tempo como parte de algo muito maior. A reportagem é iniciada com uma situação hipotética da quebra de um ovo, seguida de uma pergunta retórica indicando que seria impossível

\footnotetext{
${ }^{59}$ Disponível em:

https://www.bbc.com/portuguese/noticias/2015/07/150630 vert earth sentido tempo mlhttps://ww w.bbc.com/portuguese/noticias/2015/07/150630 vert earth sentido tempo $\mathrm{ml}$

${ }^{60}$ Parte do texto pode ser acessada através do seguinte link:

http://revistagalileu.globo.com/Galileu/0,6993,ECT545755-1719,00.html
} 
colocar a clara e a gema de volta na casca do ovo. Becker continua indicando que, na realidade, não há nenhuma lei fundamental da natureza que nos impessa de "desquebrar" um ovo. A reportagem afirma que os físicos garantem que qualquer acontecimento do nosso cotidiano poderia ser revertido a qualquer momento. A partir desta afirmação, levantam os seguintes questionamentos: Por que as coisas não se revertem? Por que o futuro é totalmente diferente do passado?

Para começar sua explicação, Becker remonta às leis de Newton, personagem com a qual várias histórias da ciência são iniciadas, afirma a reportagem. Segundo a matéria, as leis de Newton funcionam tão bem de trás para frente quanto de frente para trás - se um ovo se quebra, as leis de Newton dizem que ele pode ser "desquebrado". Para Becker isso está, obviamente, errado. Passa, então, a considerar o conceito de entropia. A reportagem afirma que a primeira pessoa a encarar esse problema seriamente foi o físico austríaco Ludwig Boltzmann. Pela termodinâmica, continua a matéria, todos os objetos do mundo têm certa quantidade de entropia associada a ele, e quando algo acontece, essa quantidade aumenta. De acordo com Becker, Boltzmann descobriu que a entropia mede o número de maneiras pelas quais os átomos podem se rearranjar, assim como a energia que eles carregam. Ou seja, a entropia aumenta quando os átomos ficam mais desordenados. A matéria explica a relação com a "seta do tempo", afirmando que o futuro é diferente do passado simplesmente porque a entropia aumenta. Assim, como forma de endossar sua teoria, Boltzmann teria desenvolvido a hipótese de que em algum ponto de um passado distante o Universo estava em um estado de baixa entropia. A reportagem faz um link entre essa proposição e a teoria do Big Bang, proposta já no século XX.

A reportagem indica que para descrever o universo em sua origem, é preciso combinar as teorias da relatividade e da quântica para formar uma "teoria de tudo". A mais promissora teoria de tudo, para Becker, é aquela que diz que todas as partículas subatômicas são compostas de minúsculos cordões. Essa teoria também defende que o espaço tem mais do que três 
dimensões e que nós vivemos em uma espécie de 'multiverso', onde as leis da física são diferentes em cada universo. Por fim, a matéria conclui que seja qual for a maneira de explicar a direção do tempo, ela sempre estará ligada àquele estado de baixa entropia do princípio do universo e que nossa maior esperança de compreensão desta temática está relacionada aos experimentos desenvolvidos no LHC (Large Hadron Colider).

A matéria da Revista Galileu é iniciada com uma série de perguntas e respostas que contrariam a ciência, tais como Quando surgiu a Terra? Há 10 mil anos, no máximo. Quanto tempo durou o período geológico do Jurássico? Menos de três meses. Como funciona a seleção natural? Impede o desenvolvimento de novas espécies. Como explicar a sofisticada bioquímica da vida? Ela foi formada segundo o planejamento de uma inteligência superior. Com essas repostas, o autor "conversa" com seu leitor, indicando que este deveria estar se perguntando se, de fato, comprou uma revista sobre ciência. Este foi o recurso usado pelo autor para dizer que tais ideias eram defendidas no Brasil, no momento da produção da matéria, por um grupo de pessoas a quem não se pode acusar de falta de credenciais científicas. Indica que alguns membros deste grupo têm artigos publicados em revistas científicas nacionais e internacionais e atuam em universidades como a USP e a Universidade Federal de Viçosa.

Nogueira indica a fundação de instituições brasileiras ligadas à defesa do criacionismo, tais como a Sociedade Criacionista Brasileira (SCB), fundada em 1972, e a Associação Brasileira de Pesquisas da Criação (ABPC), fundada em 1979. Chama atenção que no mês de abril de 2003, a ABPC trouxe ao Brasil um dos mais famosos cientistas criacionistas do mundo, o bioquímico americano Duane Gish, vice-presidente do Institute for Creation Research (ICR). Gish que, de acordo com a matéria, esteve no país outras quatro vezes e se apresentou até na USP e na Unicamp fez uma maratona de conferências por cinco Estados brasileiros. Nogueira afirma que Gish se propõe a refutar as teorias da Evolução e do Big Bang com base em argumentos científicos. Dentre eles, Gish critica a ideia de matéria e energia escura que, segundo ele, faz parte da criação de evidências para 
sustentar uma teoria. Por fim, a matéria indica que Gish também recorre à Segunda Lei da Termodinâmica, que diz que, ao longo do tempo, a entropia de um sistema fechado tende a aumentar. Para Gish "isso significa que a desorganização tende a crescer ao longo do tempo, o que é o oposto do que dizem o Big Bang e a Teoria da Evolução".

Por fim, o licenciando PE9, que também estagiou no IFSP, desenvolvendo sua regência no $2^{\circ}$ ano do ensino médio integrado ao técnico em eletrotécnica, selecionou a temática "Física nas transmissões esportivas". Sua justificativa pelo tema se deu da seguinte forma:

Pensando que recentemente tivemos grandes eventos esportivos, a Copa do Mundo de futebol masculino - 2018 e os Jogos Olímpicos no Brasil - 2016, que esportes como o futebol tem grande alcance na população brasileira, a televisão é um forte veículo de informação e a internet aparece como um novo meio de divulgação de notícias foram usadas estas fontes para o trabalho de divulgação da ciência em sala de aula (VPE9)

PE9 selecionou um conjunto de afirmações de narradores esportivos, de diversos meios de comunicação, além de um vídeo que, segundo PE9, "viralizou" na internet, no qual uma bola de basquete é lançada de uma montanha e, devido o efeito Magnus, toma uma trajetória não esperada ${ }^{61}$.

O vídeo publicado na plataforma do YouTube tem 42 segundos de duração e mostra uma bola sendo solta de uma grande altura três vezes. Nas duas primeiras, vemos uma pessoa simplesmente largando a bola. A câmera registra a trajetória da bola. No terceiro arremesso, a bola é lançada sendo girada. Como resultado desta diferença no lançamento, é possível ver que a trajetória da bola é completamente diferente das duas primeiras. Não há explicações no vídeo, mas o próprio título indica que a diferença na trajetória é explicada pelo "Efeito Magnus".

\footnotetext{
${ }^{61} \mathrm{O}$ vídeo pode ser acessado através do link: https://www.youtube.com/watch?v=M4aBTinRENo
} 
O objetivo de PE9 era problematizar, do ponto de vista físico, falas de narradores e comentadores esportivos, considerando que esses gozam, para PE9, de certa autoridade diante do público.

[...] muitas vezes estes profissionais são considerados especialistas no esporte em que transmitem e suas falas não teriam motivos para serem contestadas, mas no contexto da física acabam muitas vezes utilizando o senso comum o que não seria válido para uma explicação coerente da mecânica aplicada a estes esportes.

Algumas das falas problematizadas, do ponto de vista físico, foram as seguintes:

- “Que infelicidade! Justo na última curva o motor fumaçou! E aí companheiro, não tem prá ninguém. É uma lei básica da Física: sem força, não há movimento".

- "Quando a bola toca na grama molhada ganha velocidade".

- "A bola bateu na trave e voltou com mais força ainda. A força foi tanta que pegou na nuca do goleiro e o deixou desacordado".

- 'Matar no peito' com categoria é sempre uma jogada muito difícil de realizar. O jogador precisa estufar o peito e fazer na bola uma força exatamente igual à que a bola faz nele. Qualquer errinho, para mais ou para menos, a bola salta fora”. (TPE9)

Por fim desta descrição geral dos materiais analisados pelos professores em formação na disciplina "Oficina de Projetos de Ensino", apresentamos dois gráficos contabilizando os canais de comunicação selecionados pelos licenciandos. Assim como na análise feita dos materiais de EDC, agrupamos as reportagens considerando grupos de comunicação, como o grupo Globo, que no caso deste corpus compreende tanto a revista Galileu, quanto o site G1. 

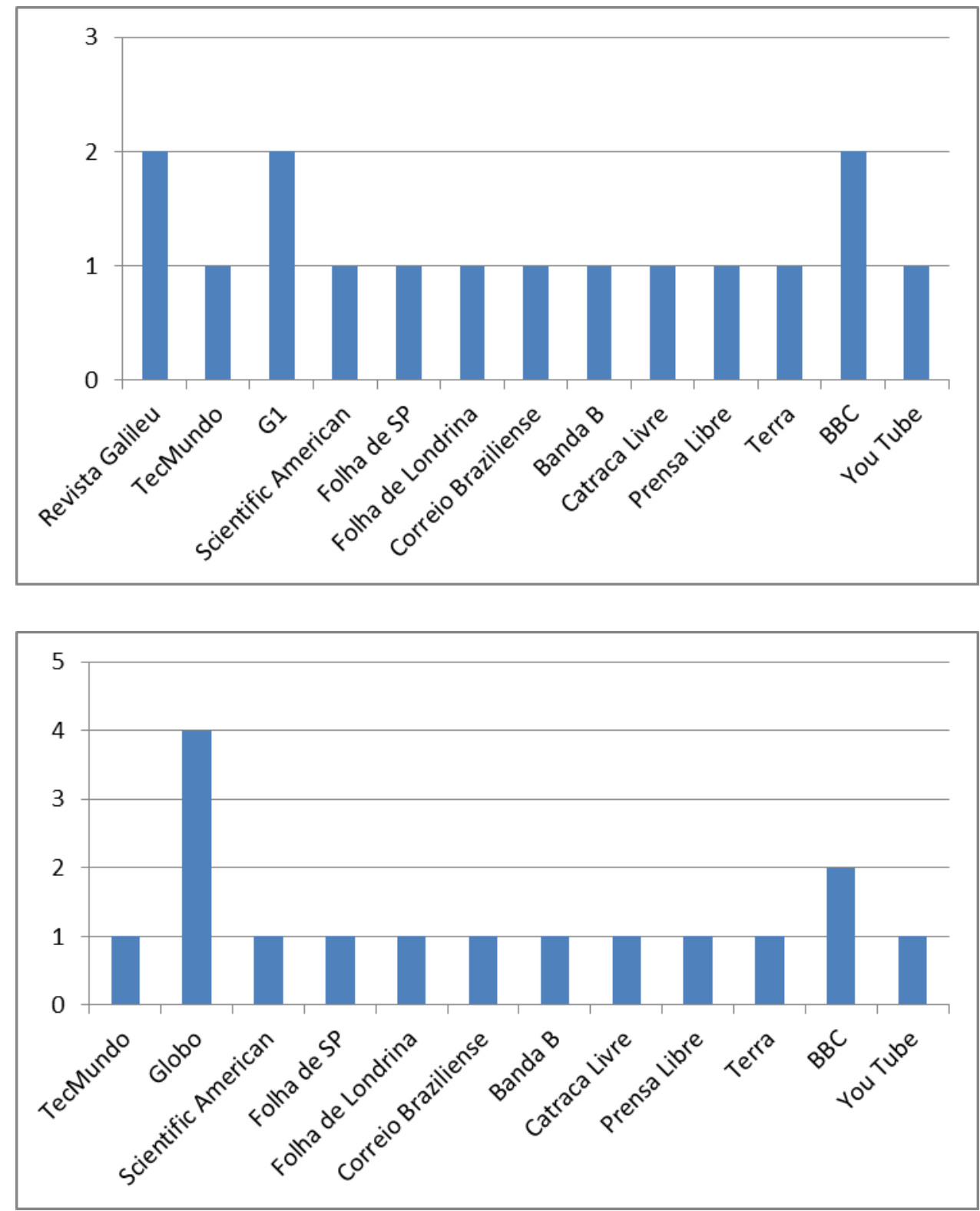

Não temos a pretensão de grandes conclusões a partir destes dados, sobretudo porque uma análise quantitativa demandaria um conjunto de dados mais robusto. Neste conjunto de dados os meios de comunicação foram mais variados, em relação aos selecionados pelos licenciandos de EDC. Contudo, novamente chama atenção o destaque para o grupo Globo. Não é novidade que este grupo é um dos mais influentes no contexto brasileiro, sendo o principal meio de comunicação acessado pela população brasileira (SECOM, 2016). O destaque é que quando o assunto é Ciência eles continuam se destacando, considerando os materiais selecionados pelos licenciandos. 
A seguir passamos à análise de nosso corpus a partir das categorias apresentadas na metodologia desta tese, sobretudo a partir dos três eixos propostos: Mídia, Ciência e Ensino. Apresentamos um quadro analítico no qual temos os mesmos eixos e categorias utilizadas na análise do corpus de EDC, mas com subcategorias distintas. De maneira geral o corpus de análise referente a disciplina de PE1 está mais focado em descrições e análises das regências, isto é, de como os licenciandos pensaram e executaram a inserção da mídia em aulas de Física. 


\begin{tabular}{|c|c|c|}
\hline Categorias & Subcategorias & Ocorrências \\
\hline \multicolumn{3}{|c|}{ Mídia } \\
\hline \multirow{3}{*}{$\begin{array}{l}\text { Contraditório e } \\
\text { confrontação de } \\
\text { diferentes materiais }\end{array}$} & Seleção de materiais com temáticas diferentes & $\begin{array}{l}\text { PE1, PE3, PE5, } \\
\text { PE6, PE8 e } \\
\text { PE9 }\end{array}$ \\
\hline & $\begin{array}{l}\text { Seleção de materiais com mesma temática e } \\
\text { abordagens não conflituosas entre si. }\end{array}$ & PE7 \\
\hline & Ausência de descrição dos materiais selecionados & PE2 e PE4 \\
\hline \multirow{2}{*}{ Questão do Poder } & Não Neutralidade da Mídia & PE3 \\
\hline & Censura & PE6 \\
\hline Usos da Linguagem & Simplificação & PE3, PE7 \\
\hline \multicolumn{3}{|c|}{ Ciência } \\
\hline \multirow{3}{*}{$\begin{array}{l}\text { Relações entre } \\
\text { Ciência, Tecnologia } \\
\text { e Sociedade }\end{array}$} & Questões climáticas e o desenvolvimento urbano & PE3 \\
\hline & Ações de governo frente a desastres naturais & PE6 \\
\hline & Aplicações e desenvolvimento tecnológico & PE8 \\
\hline $\begin{array}{l}\text { Aspectos } \\
\text { Epistemológicos }\end{array}$ & Mito do Gênio & PE2 \\
\hline \multicolumn{3}{|c|}{ Ensino } \\
\hline \multirow[b]{2}{*}{ Problematização } & Problematização da Ciência & PE1 e PE2 \\
\hline & Problematização da Mídia e da Ciência & $\begin{array}{l}\text { PE1, PE3, PE6 } \\
\text { e PE8 }\end{array}$ \\
\hline \multirow{2}{*}{$\begin{array}{l}\text { Relação Professor- } \\
\text { Conhecimento-Aluno }\end{array}$} & Relação dialógica & $\begin{array}{l}\text { PE1, PE3, PE6, } \\
\text { PE7 e PE8 }\end{array}$ \\
\hline & Relação expositiva & $\begin{array}{l}\text { PE2, PE4 e } \\
\text { PE9 }\end{array}$ \\
\hline \multirow{2}{*}{$\begin{array}{l}\text { Seleção de } \\
\text { conhecimentos } \\
\text { Científicos }\end{array}$} & $\begin{array}{l}\text { Seleção de conteúdos científicos tradicionais } \\
\text { contextualizados }\end{array}$ & $\begin{array}{l}\text { PE3, PE4, PE7, } \\
\text { PE8 e PE9 }\end{array}$ \\
\hline & Seleção de conteúdos científicos não tradicionais & $\begin{array}{l}\text { PE1, PE2, PE5 } \\
\text { e PE6 }\end{array}$ \\
\hline
\end{tabular}




\subsubsection{Categorização: Foco na mídia}

\section{Contraditório e confrontação de diferentes materiais}

Como temos insistido desde as discussões teóricas, sobretudo desde o capítulo 2 focado na epistemologia freireana, a confrontação de diferentes materiais acerca de um mesmo tema é fundamental para o desenvolvimento de uma visão crítica. Para compormos nossa própria visão de mundo é necessário reconhecer que existem várias possibilidades de olhar para um mesmo problema.

\section{Seleção de materiais com temáticas diferentes}

Analisando o conjunto de nosso corpus, percebemos que a maior parte dos licenciandos não confrontaram os materiais por eles selecionados, sobretudo por terem selecionado materiais que versavam sobre temas diferentes, embora com intersecções. O licenciando PE1 selecionou duas reportagens sobre o acelerador de partículas Sirius. Uma das reportagens focava nas obras do acelerador, mesmo tendo sofrido corte de verbas à época. Por sua vez, a outra reportagem publicada um ano depois, foca na inauguração do acelerador. Portanto, embora ambas estejam falando do acelerador de partículas, Sirius, os enfoques são totalmente diferentes. O ideal, para conseguir um contraste de percepções e de visões de mundo, seria o licenciando selecionar notícias que abordassem a questão do corte de verbas e como isso afetaria a construção do acelerador de partículas. Neste quesito, poderia ser evidenciado os meios de comunicação que buscariam posicionamentos distintos diante da política de investimentos em ciência e tecnologia empreendida pelo então "presidente", Michel Temer. Ou, por outro lado, confrontar notícias sobre a inauguração do acelerador, focando nas diferentes (ou não) repercussões.

A licencianda PE3 selecionou duas matérias que versavam sobre as ilhas de calor devido a grandes concentrações urbanas. Embora a temática em si seja a mesma, selecionou matérias em contextos especiais e temporais totalmente distintas. Na reportagem da Folha de SP, publicada em 1998, o 
foco é sobre o início dos mapeamentos por fotos térmicas de três cidades estadunidenses e alguns comentários de uma especialista sobre as ilhas de calor na cidade de São Paulo. A reportagem do jornal Correio Brasiliense foi publicada duas décadas depois da reportagem da Folha de SP. Além disso, foca no desenvolvimento urbano de Brasília. Assim, o contexto temporal e espacial impede uma confrontação de perspectivas sobre a temática das ilhas de calor de maneira mais específica. Apenas comparações gerais são possíveis, tais como a indicação da necessidade de mais arborização no planejamento urbano. A licencianda PE3 foca na abordagem física dada às ilhas de calor por cada uma das reportagens selecionadas. Para ela, o jornal "Correio Braziliense" trata de maneira mais completa o tema das ilhas de calor em relação à Folha de $\mathrm{SP}$.

A Folha de SP cita o porquê mais ou menos. Ela cita que ocorre normalmente em locais em que a superficie natural foi substituída por asfalto, concreto e outras construções, mas não fala o motivo. Já na outra reportagem ela já tenta dar uma explicação da causa. Segundo ela os materiais urbanos, como concreto e pavimentação, têm capacidade diferente dos elementos naturais. Tem um momento em que ela fala de reflexão e absorção, que é aí a questão do albedo. (VPE3).

O licenciando PE5 também seleciona uma temática em comum: a morte de pessoas por hipotermia. Contudo, seleciona matérias sobre mortes ocorridas em diferentes partes do Brasil e uma ocorrida fora do país. Em duas delas, as mortes foram causadas supostamente por baixas temperaturas, enquanto a terceira foi causada supostamente pela combinação de baixa temperatura e o uso de ventiladores. Não há indícios de comparações entre esses materiais por parte de PE5.

O licenciando PE6 também selecionou duas reportagens de temáticas diferentes. Ele empreendeu uma estratégia de comparação entre as reportagens para fomentar nos alunos a discussão sobre as atitudes dos diferentes governos acerca de catástrofes naturais. 
Depois que a gente fez a leitura eu falei: tá bom, o que a gente pode tirar comparando os dois textos? Silêncio, ninguém comentou. Uma aluna leu o primeiro, ela começou a ler. Aí chegou na segunda imagem de como era a festa das minervas ela parou e eu continuei lendo. Então a cidade estava em festa, mas do outro lado estava tudo devastado. E o segundo texto é esse: "presidente Hoover dobrou o tamanho do monumento e em 1980 expandiu-se novamente 4,2 milhões de acres no parque nacional de reserva de Katmai". Então são dois textos que trazem abordagens diferentes, enviesados obviamente. Eles são maiores do que isso. São publicações recentes de 2016 e 2012 e que remontam o que aconteceu. (VPE6, grifos nossos).

Embora não tenha considerado que selecionou duas reportagens que, a rigor, versavam sobre temas diferentes, destacamos que o licenciando PE6 tinha consciência de que os textos tinham abordagens diferentes e, sobretudo, que essas abordagens são enviesadas: isto é, não existe possibilidade de produção neutra. Contudo, o licenciando avalia que a tentativa de comparar as atitudes de governos através da confrontação entre essas duas matérias não foi bem sucedida.

Lendo cada parágrafo eu comentava: ele fala tal coisa, tal coisa...comparando as duas matérias. De novo eu fiz essa comparação que eu acabei de fazer: o que abordam os dois e o que eu queria trabalhar. Aí eu senti que não foi legal. Não foi o que eu esperava, porque eu precisei expor o que eu queria trabalhar, isso não surgiu naturalmente. (VPE6)

A ideia do licenciando era confrontar como o governo de cada país lidou com os desastres. Isto é, não fez uma confrontação entre os materiais midiáticos, senão uma confrontação entre governos, baseado na descrição feita pelos meios de comunicação. Neste caso, as versões de cada uma das reportagens foram consideradas como sendo versões únicas dos fatos.

A licencianda PE8 selecionou duas matérias que se aproximam do conceito de entropia. Contudo, a reportagem da BBC aborda o tema da 
entropia para discutir, principalmente, sobre o conceito de tempo. Por sua vez, a matéria da revista Galileu tinha como objetivo central problematizar a institucionalização de interpretações criacionistas. A matéria buscou enfatizar como alguns membros destes grupos criacionistas têm "credenciais" científicas e buscam argumentos científicos para defenderem seus posicionamentos. Em um desses exemplos, a Galileu menciona como um criacionista usou o conceito de entropia para indicar incoerências com a teoria do Big Bang. Assim, embora ambas as matérias versem sobre entropia, têm abordagens e temas completamente diferentes. A principal confrontação que a licencianda $\mathrm{PE} 8$ fez foi com relação às abordagens conceituais errôneas feitas pelos materiais midiáticos selecionados.

Durante a intervenção foi comovente a interpelação de uma das alunas: "Mas, 'pro', então temos que desconfiar de tudo o que lermos?" dado que esse era um dos objetivos da aula, além de passar os conceitos de entropia. (VPE8)

Este trecho mostra como a licencianda, apesar de não confrontar os materiais entre si, buscou criticar ambas as produções, de modo que uma de suas alunas chegou à conclusão de que é necessário "desconfiar" de tudo o que lemos. Desconfiar das produções é condição para que se possa sair da passividade em relação à mídia.

\section{Seleção de materiais com mesma temática e abordagens não conflituosas entre si.}

O licenciando PE7 confrontou reportagens sobre o desenvolvimento de uma camisinha autolubrificante. Vale destacar que o licenciando indicou a reprodução do texto da $\mathrm{BBC}$ pela Globo, o que indica um processo de homogeneização dos assuntos abordados pela mídia. As abordagens dadas às reportagens publicadas na $\mathrm{BBC}$ e Terra, embora não sejam cópias uma da outra, também não são conflituosas. Isto é, ambas abordam a construção da nova camisinha como um possível meio de incentivar as pessoas a usar preservativos no ato sexual, o que geraria maior segurança contra infecções sexualmente transmissíveis, além de evitar gravidez indesejada. Contudo, a 
comparação entre as duas reportagens permitiu ao licenciando PE6 verificar que as reportagens apresentaram dados divergentes.

A notícia [da Terra] trouxe uma estimativa que eu não achei na notícia original da BBC. Acho que eles tiraram a informação da "bunda", que foi de que esses 600 movimentos equivalem a $15 \mathrm{~min}$ de relações sexuais. Não tem informação nenhuma sobre isso na notícia da $B B C$ e eles não têm nenhuma referência de onde eles tiraram isso. Então eles inventaram, para mim. Não tem nenhuma informação de onde eles tiraram isso. Pelo menos nas imagens da notícia da Terra eles colocam que tiraram da notícia da $B B C$. Essa é a única menção de referência deles para produzir a notícia. (VPE7)

Este recorte versa sobre algumas características da mídia, como a identificação de uma circulação circular da informação, ao considerar claramente que a notícia da Terra está pautada na produção feita pela BBC sobre a camisinha autolubrificante. A partir dessa comparação direta entre BBC e Terra, o licenciando conclui que a conversão de movimentos para o tempo da relação sexual foi colocada de maneira pouco clara, sobretudo por não indicarem a referência de tal afirmação.

Este mesmo licenciando, PE7, ao confrontar os materiais selecionados, considera que a notícia da BBC apresenta mais dados da pesquisa relatada em relação à Terra.

Eu mostrei para eles a notícia do Terra. Eu não mostrei a original da $B B C$, mas eu fiz esses comentários de que a $B B C$ tinha muito mais dados da pesquisa, mesmo. Como, por exemplo, como o material se autolubrifica, que não tem tanto essa informação na notícia da Terra (VPE7).

\section{Ausência de descrição dos materiais selecionados}

Os licenciandos PE2 e PE4 não apresentaram nenhuma descrição dos materiais midiáticos que selecionaram. Isto implica não apenas na impossibilidade de categorizarmos suas produções nesta tese, mas, 
principalmente, que não consideraram a descrição desses materiais para a análise que empreenderam e para suas regências. Em nosso entendimento, isto indica que os materiais midiáticos foram encarados simplesmente como uma ferramenta didática que apoiou a discussão de temas científicos em sala de aula. PE2 focou na discussão do paradoxo dos gêmeos, inserindo, também, algumas discussões sobre o mito do gênio. PE4 abordou um tema com implicações sociais: "gatos de luz". Contudo, em sua análise indica que todos os materiais de mídia que selecionou, sem se referir a quais foram, criticaram os "gatos de luz" e indicaram que parte desses desvios eram feitos pela classe média. Além disso, PE4 enfatiza que essas produções não falam sobre conceitos físicos como tensão, corrente e resistência.

Os materiais que eu peguei falando de gato de luz, todos criticam o gato. Nenhum a favor. Não falam, na verdade, da matéria da física, dos problemas que ele dá [...] assim, questões de tensão, resistência, corrente, amperagem. Eles não falam nada. $O$ que eles falam, na verdade, são que principalmente, no que eu li, que não são gatos de luz de periferias. A maioria dos que eu vi, na verdade, são de classe média, gente da alta que rouba energia elétrica. Não rouba energia elétrica da maneira que o pobre faz. A pessoa compra um medidor de luz. Vai lá nas configurações dele, quebra um lacre que ele tem, muda todas as configurações dele. Em vez de mandar ler lá tantos quilowatts gastos, está inferior. Então é um problema social muito grande.

Chama atenção que a principal característica que o licenciando identificou foi a falta de apresentação de conceitos físicos como corrente, tensão e resistência nas matérias que abordaram a temática dos gatos de luz. Entendemos isto como uma busca por justificar o ensino desses conceitos em sua regência. Além disso, as descrições genéricas dos materiais indicam que os gatos de luz são feitos pela classe média. Quais meios de comunicação indicaram isso? Quais interesses poderiam haver por trás dessas denúncias? Essas são algumas das questões que poderiam surgir a partir de uma problematização da própria mídia. 
Por fim, temos um resultado interessante em nosso corpus com relação à confrontação entre materiais. A licencianda PE8 pediu uma avaliação de sua regência ao Professor que a recebeu no estágio. Embora tenhamos considerado que PE8 selecionou matérias com temáticas diferentes, o Professor enfatizou em sua avaliação a importância de usar mais de uma fonte como forma de estimular o exercício crítico dos estudantes.

Eu pedi uma avaliação para o Professor [...] A primeira coisa que o Professor falou que achou bacana foi eu permitir que os alunos concluíssem sozinhos que eles precisam ser críticos com o que leem. [...] Aí ele falou que gostou de eu ter usado duas fontes. E eu disse que na verdade era uma obrigatoriedade da disciplina...aí ele falou: ah, então tá bom. Mas, enfim, foi uma coisa que ele reconheceu como válido você usar um contraponto de fontes. (VPE8)

A avaliação do Professor também indica que a licencianda busca construir uma postura crítica diante dos materiais de mídia junto com os alunos. Isto é, não bastaria dizer aos alunos, de forma expositiva, que eles precisam ser críticos com o que leem. É preciso desenvolver atividades concretas para que cheguem, na prática, a essa conclusão.

\section{Questão do Poder}

\section{Não Neutralidade da Mídia}

Como defendia Paulo Freire, as produções da mídia não são boas e nem más por si mesmas. São produções necessariamente enviesadas. Enviesadas no sentido de serem tributárias de visões de mundo e de interesses específicos, seja dos meios de comunicação ou de indivíduos. Com isto, percebe-se que uma das características centrais de se reconhecer acerca da produção da mídia é que ela não é neutra. Em nosso corpus temos exemplos de consideração da não neutralidade da produção midiática. Chamamos atenção para a afirmação da licencianda PE3:

Conclui-se que se nem a ciência em si é neutra, quanto mais uma reportagem sobre ela. (TPE3) 
Interessante a consideração da licencianda de que tanto a mídia quanto a própria ciência não são produções neutras. É uma consideração epistemológica.

\section{Censura}

Além dessa consideração de PE3, temos em nosso corpus outros exemplos de exercício do poder que envolvem a mídia. Mais especificamente, o licenciando PE6 relata a censura do governo guatemalteca acerca do incidente com o vulcão Katmai.

Na parte leste da Guatemala estava acontecendo o primeiro evento "festa de minerva" em que o ditador Estrada Cabrera da Guatemala da época investiu muita grana para que a Guatemala fosse bem vista no exterior e coincidiu a época da festa com o pós desastre. Então todos os jornais da época foram censurados. Nada ia pra fora ou chegava à população. Os jornais da Guatemala que falavam sobre essa cidade tratavam como uma "chuva de cinzas tênue". Não foi nada tênue, pela imagem que foi publicada. Quem sofreu mais foi a população. (VPE6, grifos nossos)

\section{Usos da Linguagem}

\section{Simplificação}

Em nosso corpus pudemos verificar que, em geral, os licenciandos tinham como objetivo aprofundar os conceitos físicos abordados nos materiais selecionados. Neste sentido, alguns deles apontavam que as reportagens sobre ciências apresentam os conteúdos físicos de maneira simplificada.

Aqui eu já coloquei a notícia do Terra. Eu não li a notícia inteira com eles e nem fiz eles lerem. Eu li e comentei os pontos principais que a notícia se foca. Eu comentei que a notícia da Terra traz uma ar de muito mais "oh, vamos falar de um negócio que vai chamar atenção, sem dar muitos detalhes". Porque eles não explicam quase nada do que aconteceu. Falam: "ah, um conjunto de cientistas aí fizeram uma 
camisinha que se autolubrifica, não sei como foi testado, se foi testado e é isso aí..."(VPE7)

Esse extrato da análise do licenciando PE7 indica tanto a simplificação que ele atribuiu aos materiais selecionados como uma abordagem sensacionalista, focada apenas em chamar atenção dos leitores, segundo PE7.

A análise de PE3 deixa mais clara essa perspectiva de simplificação e a busca por aprofundar os conceitos físicos a partir das reportagens.

Eu usei a mídia mais para trazer esses problemas. O jornal não tenta explicar as causas do fenômeno. Então falei, ah...vou pegar ele mas não cita conceito assim direitinho. Ele só vai falar porque acontece: as cidades revestidas de concreto, de asfalto, etc. e isso influencia, ponto. Não falam o "porquê". (VPE3).

[...] porém o jornal só dá uma introduzida no fenômeno, as vezes só pontuando que é por causa dos diferentes materiais mas não dizendo o porque dos diferentes materiais causarem esse efeito [de ilhas de calor], as vezes ate cita o porque mas não fala o nome do fenômeno, como albedo por exemplo (TPE3).

Entendemos que a intenção de PE3 ao selecionar esses materiais foi exatamente a de explorar a abordagem simplificada do fenômeno de ilhas de calor para, a partir dessas reportagens, aprofundar na discussão física do fenômeno. Isto é, o uso da mídia se deu como uma forma de introduzir a temática da aula. Voltaremos a esta análise no eixo de análise de ensino.

\subsubsection{Categorização: Foco na Ciência}

Nosso corpus indica que o principal foco dos licenciandos foi com a abordagem de conceitos e teorias física a partir dos materiais midiáticos selecionados. O que nos chamou atenção é que mesmo conceitos físicos tidos como tradicionais, como atrito, entropia, temperatura, calor, etc. foram trabalhados de forma contextualizada e com implicações em problemas reais 
a partir das abordagens de materiais da mídia. Relacionar atrito à fabricação de uma camisinha autolubrificante, abrindo margem a discussões que transcendem a ideia de atrito em si, tais como discussões sobre sexo, sobre prevenção de doenças sexualmente transmissíveis, etc. Relacionar temperatura e trocas de calor com as condições de vida a que muitas pessoas são acometidas ao não terem meios materiais para se isolar termicamente, culminando, no limite, a sua morte. Relacionar entropia e cozinha, etc.

\section{Aspectos Epistemológicos}

\section{Mito do Gênio}

Embora os licenciandos tenham articulado o conhecimento físico de maneira contextualizada, nosso corpus indica que não privilegiaram discussões epistemológicas da ciência. A abordagem de PE2 foi a única que declaradamente e conscientemente abordou aspectos epistemológicos da ciência, sobretudo ao problematizar o mito do gênio através da figura de Einstein.

E comecei a ler uma parte que eles falavam que "quando Einstein desenvolveu a teoria da relatividade geral ele teve a brilhante ideia de não sei o que..."aí eu perguntei para eles assim: isso daqui não traz um desconforto pra vocês? Aí eles: não!. Aí eu disse: pois devia trazer, porque eles tratam o cara como um gênio. Aí muitos disseram: ah, mas ele não é um gênio? Aí é que está o problema, não é só porque ele é um cientista, que trabalha com isto, que ele é um gênio. Aí comecei a problematizar essa ideia de que a ciência é linear e que acontece sem nenhum erro, e que as coisas acontecem cronologicamente uma em seguida da outra, tudo certinho, que é uma visão muito errada que a gente tem de ciência, assim como endeusar os cientistas. (VPE2)

Interessante enfatizar que mesmo PE2 que trabalhou de maneira mais direta questões epistemológicas, considerou que tais discussões são complementares. 
Durante a aula eu disse que algumas palavras que a gente costuma usar não são muito boas para exemplificar o que a gente quer. Tipo: "provar alguma coisa", aquilo é "verdade", palavras assim eu critiquei e quis trazer uma discussão mais para a ciência em si. Como tava no final do semestre e já tinha acabado a matéria que cai no vestibular, eu achei que estava na liberdade de falar alguma coisa que não cai no vestibular e que é uma coisa mais filosófica. (VPE2)

Percebemos neste extrato que o licenciando só achava que a discussão epistemológica, filosófica, poderia ser feita porque a matéria que "cai no vestibular", que pode ser entendida como objetivo primeiro, já estava encerrada. Assim, a discussão epistemológica entraria como uma espécie de "bônus". Isso não traduz o posicionamento do licenciando simplesmente, mas sim, em nossa interpretação, em como as condições concretas de desenvolvimento dos estágios supervisionados influenciaram nas regências dos licenciandos. Isto é, as propostas de ensino desenvolvidas na universidade e que buscam abordagens que conflitam com as perspectivas educacionais da escola que recebe o estagiário gera tensões que implicam no desenvolvimento das atividades dos licenciandos. $\mathrm{Na}$ descrição da escola em que estagiou, PE2 enfatiza a missão da escola como preparadora para vestibular.

Quando terminou a aula perguntei para ele [Professor que supervisionou o estágio] o que tinha achado da aula. Ele falou que achou muito legal, mas...claro, sempre tem um "mas". Ele disse que os alunos não prestaram atenção em nada. $\underline{\text { A escola se diz preparatória }}$ para o vestibular. Quando um pai vai fazer a matrícula nesta escola ele já espera que a aula que é dada lá seja voltada para o vestibular. Então, entendi que muitos deles, quando eu comecei a falar de física moderna, pensaram: "ah, isso aí não cai no vestibular" (VPE2).

Então, além da abordagem filosófica, PE2 considerou que falar de física moderna não estimulou os alunos a participarem da aula, sobretudo por estarem focados na preparação para o vestibular. Assim, a perspectiva 
da escola que o recebeu condicionou a forma como desenvolveu sua regência e, principalmente, como a avaliou.

\section{Relações entre Ciência, Tecnologia e Sociedade \\ Questões climáticas e o desenvolvimento urbano}

Em relação a aspectos de Ciência e Sociedade, damos destaque a abordagens relacionadas ao clima, como a feita por PE3 ao problematizar a organização em grandes centros urbanos e como isso influencia no clima local, especialmente através do efeito conhecido como Ilhas de Calor. PE3 buscou desenvolver compreensões tanto das abordagens dadas pelos jornais ao tema de ilhas de calor como compreensões sobre o próprio fenômeno, projetando essas compreensões como condição para que os alunos pudessem propor soluções aos problemas identificados.

[...] entendendo com isso o problema apresentado pelos jornais, tanto quanto as causas do fenômeno, para a partir deste entendimento do porque as ilhas de calor ocorrem, os alunos pudessem desenvolver soluções para elas.

Como buscamos delinear no capítulo 2, a denúncia sem o anúncio é insuficiente. Assim, a licencianda PE3 tinha a perspectiva de que seus alunos não só compreendessem o fenômeno das ilhas de calor, mas fossem capazes de pensar e propor soluções para o problema identificado.

\section{Ações de governo frente a desastres naturais}

O licenciando PE6 buscou em sua regência estabelecer relações diretas entre desastres naturais e as atitudes tomadas por diferentes governos diante desses desastres.

A erupção guatemalca teve grande repercussão muito tempo depois do ocorrido pois, como traz o artigo selecionado do jornal "Prensa Libre" (publicado em 25 de outubro de 2016) - Um desastre que Estrada Cabrera insistió em negar, houve grande censura por parte do governo da época devido ao evento que ocorreu no mesmo ano na 
outra extremidade do país e teve grande investimento. Já a erupção estadunidense trouxe um repertório para reflexão a cerca de como aconteceram os fatos e as ações na sua sequencia, pois o vulcão tendo explodido e causado danos tão grandes quanto o primeiro, teve seus danos amenizados por políticas públicas de preservação da área, da fauna e flora. (TPE6)

Em linhas gerais, o licenciando buscou a confrontação das atitudes de um governo ditatorial, de Estrada Cabrera na Guatemala, e de um governo democrático, dos EUA. De acordo com a interpretação de PE6, o governo ditatorial não apenas demorou a tomar atitudes em relação às implicações da erupção do vulcão, como censurou a mídia da época, que divulgou o ocorrido como se tivesse sido em proporções muito menores do que realmente aconteceu. Já o governo democrático isolou a área atingida pela erupção e a transformou em uma grande reserva natural.

\section{Aplicações e desenvolvimento tecnológico}

Além de aspectos sociais, o licenciando PE7 abordou questões relacionadas ao desenvolvimento tecnológico, mais precisamente sobre a construção de uma camisinha autolubrificante que, além de prometer mais conforto no ato sexual, tem a pretensão de prevenir de maneira mais eficiente doenças sexualmente transmissíveis. Isto é, o desenvolvimento tecnológico neste caso é abordado tendo em vista objetivos sociais, com implicações sobre o bem estar e saúde dos cidadãos e cidadãs.

Por fim, a inserção do material midiático com notícias de diversos portais online como terra, globo e BBC falando a tal camisinha autolubrificante e possíveis implicações dessa linha de pesquisa na ajuda à prevenção de doenças infecciosas e gravidez indesejada. (TPE7) 


\subsubsection{Categorização: Ensino}

\section{Relação Professor-Conhecimento-Aluno}

\section{Relação dialógica}

Diferentes abordagens e metodologias foram empreendidas em busca de inserir materiais de mídia em aulas de física pelos professores em formação. De maneira geral, nosso corpus indica que os licenciandos buscaram desenvolver em suas regências abordagens dialógicas e que colocassem os estudantes como atores principais de seus desenvolvimentos.

Em nosso corpus há indicativos da preocupação que os licenciandos tiveram em considerar os conhecimentos prévios dos estudantes para estruturarem suas regências.

$O$ início da conversa foi a montagem de um quadro de ideias e conceitos que os próprios alunos relacionaram à atrito com o objetivo de entender se já existe alguma rede de conhecimento prévia (TPE7)

Para você explicar conteúdos que você quer explicar para o aluno, tem que fazer coisas que façam sentido para ele, que tenha alguma coisa relacionada ou à vivencia dele ou ao repertório histórico deles (VPE8)

Fiz uma primeira atividade diagnóstica, baseado na ideia do GREF, de relacionar palavra a conceitos, tudo vindo do que os alunos falavam com algumas coisas que íamos encaixando... (VPE7)

Além de considerarem os conhecimentos prévios dos alunos e priorizarem abordagens dialógicas, temos em nosso corpus indícios de considerações da apreensão de conhecimento como estratégia indispensável para a compreensão e proposição de mudanças do mundo.

Eu peguei uma fala de um dos textos que a gente leu com o Danilo, que é: "um dos objetivos mais comuns da popularização científica é considerá-la como um processo de estreitamento do vão cultural entre a elite e outros grupos sociais". Na verdade, dessa disciplina eu acho que para mim resume bastante a importância de tudo o que a gente 
discutiu. A importância de usar o conhecimento como uma forma de poder, uma forma de dar poder aos alunos. (VPE8, grifos nossos).

A apropriação de conhecimentos historicamente constituídos está diretamente relacionada à possibilidade de compreensão e atuação crítica no mundo. Para Freire, isto está diretamente relacionado à questão do poder: "Por causa do problema político do poder, você precisa aprender a se apropriar da linguagem dominante, para que você possa sobreviver na luta para mudar a sociedade" (FREIRE, 2011, p.124).

Algumas propostas de avaliações das regências mostraram como os licenciandos priorizaram atividades que valorizasse posturas críticas e criativas dos estudantes. PE3, por exemplo, sugeriu aos alunos que desenhassem esquemas de como funcionam as ilhas de calor e quais propostas poderiam ser feitas para solucionar o problema levantado.

Como avaliação da regência eu pedi um esquema livre, podendo ser desenhado ou em forma de resumo, sobre o que eram as ilhas de calor e como se formavam e também que eles apresentassem soluções possiveis para o problema (TPE3).

PE6, após a discussão sobre vulcanismo e sobre como os governos da Guatemala e EUA lidaram com desastres naturais ocorridos no início do século XX, propôs uma atividade em que os alunos desenvolveram um teatro, envolvendo personagens como jornalistas, população e representantes do governo.

Eu trouxe a ideia de fazer um teatro. Eu instruí um único aluno, que o papel dele seria o de jornalista. Nisso, ele não entendeu como um jornalista que ia entrevistar. Ele entendeu como um âncora. Então ele sentou e ficou de frente na mesa grande no meio. Aí vieram os outros alunos. De um lado ficaram os alunos que representavam a população. Eles levantaram um discurso de "perdemos tudo", "perdemos fazenda", não sei o que lá...E do outro lado o governo. OS alunos que fizeram o papel do governo foi o presidente, o vice dele, o 
ministro da fazenda e o ministro da cultura. $O$ presidente que escolheu os outros cargos dos amigos. Perguntei porque ministro da fazendo e ministro da cultura no caso de desastre. Aí não souberam responder. Aí pedi para os demais da turma para participar também. Disse assim: a gente precisa criar um desastre. Aí surgiu um terremoto. Um país? Coreia. Então foi um terremoto na Coreia. E o que estava acontecendo na Coreia [no enredo da história criada] era uma questão econômica que estava envolvida. Eles levantaram que a Coreia estava com problema na agricultura. $O$ menino, ancora, falou "jornal da Globo"...beleza, jornal da globo coreano...aí a turma deu risada. Funcionou como um quebra gelo. Todo mundo tava interagindo. Ao longo dessa entrevista ele foi perguntando pra população o que achavam do que aconteceu, para o governo o que ele ia tomar de atitude. E a população cobrando o governo e o governo dizendo...o aluno que representava o governo disse assim: "nós vamos aumentar os impostos para que a gente possa reverter o desastre". Aí o ancora interviu e falou assim: "Você acha que seu povo vai tirar dinheiro da onde pra pagar esse imposto? Nessa hora eu fiquei assim: nossa! Está acontecendo mesmo! Era o que eu queria, esse tipo de discussão. Aí depois ele [o âncora] perguntou o que o presidente achava da liberação das drogas. Foi curto isso. Logo eu voltei para o tema que eu queria, de como um desastre poderia ser revertido, quais ações do governo. Essa entrevista encerrou com o ministro da fazenda pedindo dinheiro emprestado. Tipo, eles montaram um teatrinho na hora: o ministro da fazenda estava pedindo dinheiro emprestado. Ele não criou a ideia de FMI. Eu achei a ideia interessante (VPE6, grifos nossos).

Chama a atenção no relato da aula de PE6 que em meio ao desenvolvimento da atividade, que considera amplamente a capacidade criativa dos alunos, surgiu um tema que a priori não tinha nada a ver com o tema da aula: liberação das drogas. Como o licenciando tinha pouco tempo disponível para sua regência, não pôde permitir que os alunos pudessem 
apresentar suas perspectivas acerca de um tema que surgiu a partir de suas próprias inquietações. Entendemos esta passagem como indício da importância de empreender as seleções de temas e conhecimentos a partir da própria interação com os estudantes.

A licencianda PE8 buscou uma abordagem dialógica e, em sua análise, comentou sobre as diferenças entre as abordagens dialógica e expositiva, sobretudo nos desdobramentos cognitivos dos alunos.

Na semana anterior da minha regência o Professor já tinha dado o conteúdo de entropia. E, no final da aula ele deu um exercício que era um textinho que era assim: "Após o big bang a Terra era uma massa viscosa, quente e com o tempo foi resfriando até endurecer e formar a crosta. Isso significa que a Terra antes tinha mobilidade, tinha uma temperatura maior e depois resfriou e solidificou. Ou seja, ou a teoria do big bang está errada ou a segunda lei da termodinâmica está errada porque se esfriou e solidificou, diminuiu a entropia”. A questão era essa. Era para os alunos discutirem. E eles se deram muito mal. Se confundiram. O Professor explicou, mas eles ainda ficaram com dúvidas. $E$, por causa disso, eu decidi fazer a regência em cima disso. A questão era: quando você fala a teoria eles vão acompanhando, né? Esse é o grande ponto da diferença entre uma aula participativa $e$ dialogada para uma aula expositiva. Na aula expositiva é muito fácil acompanhar o raciocínio do Professor, porque ele tá lá organizadinho falando, faz sentido. Você acha que está entendendo. $O$ aluno acha que está entendendo. A hora que você faz um questionamento que sai do esqueminha do que o Professor estava falando na aula, aí é que o Professor se toca que os alunos não entenderam nada. Aí os alunos mesmos se dão conta de que não entenderam. Então, essa foi a motivação da aula. (VPE8, grifos nossos).

Consideramos que a estratégia empreendida por PE1 também buscou estabelecer uma relação dialógica entre Professor-Conhecimento-Alunos. PE1 proporcionou aos alunos espaço para que pudessem, em primeiro 
momento, selecionar partes dos textos midiáticos selecionados que precisavam/queriam aprofundar, além de propor atividade para que os alunos se posicionassem diante de possíveis aplicações do acelerador de partículas Sirius.

Pedi para que eles grifassem no texto quais eram os conceitos e teorias que eles achavam estranho, para a gente debater no final...a gente debateu, tinha algumas palavras como "Iuz síncroton", o que é raio-x, apareceram várias dúvidas e esse foi um debate mais geral. Aí eu pedi para eles formarem grupos para que cada grupo defendesse uma aplicação do acelerador Sirius e qual que seria a contribuição dele para a sociedade, o que que tem haver eu com o acelerador? Essa parte não foi tão efetiva porque acabou desviando no final da aula (VPE1).

Em seguida abrimos espaço a um debate sobre quais termos ou teorias (Física e Químicas) desconhecidas foram destacadas, os alunos mostraram bastante interesse em entender de onde surge a luz síncontron, proporcionando junto a professora Adriana um rico debate de ideias e conceitos físicos, assim como suas possíveis linhas de pesquisa e benefícios para o País. Em seguida foi proposto a divisão da turma em pelo menos 2 grupos (na realidade surgiram algumas dezenas de duplas e trios) afim de defenderem uma aplicação e linha de pesquisa para o Sírius, de forma de convencer a população da importância de tal investimento. Assim os alunos (em todas as salas) acabaram discutindo entre eles sobre outros temas da Física, fugindo dos objetivos da aula, no entanto não fugindo da temática proposta, o que proporcionou em um agradável debate com as turmas. Destacaram-se os temas debatidos com as turmas: Como se dá o funcionamento e estrutura de um chuveiro, para a turma do $3^{\circ} \mathrm{K}$; Como funciona o microscópio (óptico e eletrônico), para a turma do $3^{\circ} \mathrm{O}$; $O$ que é radiação e o uso dos $\operatorname{Raios}-X$, para a turma do $3^{\circ} \mathrm{N}$; Os aceleradores de partículas podem "abrir" um buraco negro? Para as turmas dos $3^{\circ} \mathrm{M}$ e $3^{\circ} \mathrm{L}$; (TPE1). 
Embora PE1 tenha considerado que as discussões "fugiram" dos objetivos da aula, destacamos que sua abordagem, que consideramos dialógica, proporcionou aos alunos abordarem temas de interesse que tinham correlação com o tema da aula, como indicado pelo próprio licenciando.

\section{Relação expositiva}

Consideramos que o licenciando PE2 desenvolveu, de maneira geral, uma regência que priorizou a exposição de conteúdos, tanto de conceitos científicos quanto de aspectos relacionados à dinâmica de funcionamento da ciência.

Eu comecei com o paradoxo dos gêmeos, passando um vídeo. Era um vídeo mais de divulgação da ciência do que midiático mesmo. $\boldsymbol{O}$ vídeo explicava mais o paradoxo em si. Enquanto o vídeo rolava eu parava e explicava. Eu parei e perguntei se eles sabiam o que era um paradoxo e a maioria não sabia responder muito bem. Achavam que era uma coisa que era errada. Eu falei que era uma contradição dentro do próprio conceito. Aí eu peguei a notícia e comecei a ler para eles. Era do G1. Li as partes que eu achei interessante e falei assim: vocês veem algum problema na notícia? Eu antes tinha falado que ia pegar uma notícia que divulga a ciência de forma errada e uma notícia que era mais certa. Aí eu falei: "presta atenção nesta parte aqui". E comecei a ler uma parte que eles falavam que "quando Einstein desenvolveu a teoria da relatividade geral ele teve a brilhante ideia de não sei o que..."aí eu perguntei para eles assim: isso daqui não traz um desconforto pra vocês? Aí eles: não!. Aí eu disse: pois devia trazer, porque eles tratam o cara como um gênio. Aí muitos disseram: ah, mas ele não é um gênio? Aí é que está o problema, não é só porque ele é um cientista, que trabalha com isto, que ele é um gênio.(VPE2, grifos nossos).

Consideramos que PE1 abordou o paradoxo dos gêmeos de maneira expositiva e sem nenhum indício de problematização. Contudo, aborda 
questões que julgamos relevantes com relação ao tratamento dado a Einstein pela mídia. Mas a maneira como o fez nos pareceu pouco efetiva, sobretudo porque impôs sua leitura aos estudantes, que viam Einstein como um gênio. Como apontou Guimarães em diálogo com Mariana Faraco no livro Educar com a Mídia a importância de estimular a criatividade do aluno/leitor para a recriação do conhecimento (FREIRE \& GUIMARÃES, 2011, p.148), sendo indispensável o diálogo em "um encontro de Sujeitos interlocutores que buscam a significação dos significados.” (FREIRE, 1971 apud MEDITSCH \& FARACO, 2003, p. 3).

O licenciando PE4 não descreve em detalhes seu plano de aula e o desenvolvimento de sua regência. Contudo, inferimos que PE4 empreendeu uma abordagem expositiva de conceitos físicos como corrente, tensão e resistência.

Na questão da regência que foi aplicada foi na questão do Gato de luz, sendo que não foi aplicada para discussão do que certo ou errado mas sim na questão de mostrar para o aluno, a questão do conceito de corrente, tensão, e amperagem, e potência $x$ trabalho. Sendo que este assunto o gato de luz estava como conteúdo no livro de Física que o aluno tem para estudar a matéria (TPE4, grifos nossos).

A licencianda PE9 iniciou sua regência com uma exposição das leis de Newton para, em seguida, os alunos analisarem algumas falas de narradores esportivos a partir dessas leis.

Para o preparo da regência foi organizada uma introdução teórica de revisão sobre as leis de Newton e dentro da segunda lei foi demonstrada a equação do momento linear (quantidade de movimento). Deduzir a equação da quantidade de movimento com a segunda lei de Newton é uma forma de começar a mostrar como alguns conceitos estão relacionados, pois em muitos casos, como em apostilas, as deduções e interligações entre os conteúdos não são esclarecidos, deixando a sensação que alguns estudos da física estão relacionados casos específicos (plano inclinado com blocos, colisões 
com patinadores e bolas de bilhar, etc.). Após a introdução teórica teve início das analise das falas durante as transmissões esportivas com o auxílio do artigo que forneceu as frases que seriam utilizadas, estas frases utilizavam conceitos de mecânica clássica (leis de Newton). (TPE9)

Não fica clara como a análise foi feita pelos alunos e se essas análises foram compartilhadas entre eles. PE9 indica, apenas, que conseguiram analisar as frases de narradores esportivos de maneira coerente, embora tenham apresentado dificuldades com a primeira lei de Newton.

Os alunos conseguiram analisar as frases e conceitos de maneira coerente, houve dificuldade no entendimento da primeira de lei Newton, acaba não sendo tão clara para o senso comum, não vemos o movimento retilíneo uniforme quando não há força aplicada em um corpo no cotidiano (TPE9).

\section{Problematização}

\section{Problematização da Mídia}

Como estratégia de inserir os materiais de mídia em suas aulas, foi recorrente que os licenciandos não lessem os textos completos, mas extratos previamente selecionados. Além disso, nosso corpus indica que a maior parte dos licenciandos usou a estratégia de pedir a diferentes alunos que lessem parágrafos selecionados.

Eu comecei a aula com o texto da Galileu. Cada vez que eu queria falar da reportagem eu pedia para os alunos lerem o parágrafo que eu queria. (VPE8)

Ali já tinha acabado a primeira aula [no qual apresentou diversos conceitos sobre núcleo e manto terrestre, hotspots etc.]. Na segunda aula, eu avisei que a gente ia ter uma atividade. Eu peguei duas matérias locais. O primeiro da Guatemala, em espanhol, eu traduzi mais ou menos. O segundo é em inglês, de um jornal do Alaska, e eu traduzi mais ou menos, também. Eu não usei a matéria toda em 
nenhum dos dois, porque eu pensei assim: talvez, a minha abordagem, o meu enfoque, ele esteja totalmente baseado nisso: como eu vou querer trabalhar? Então, o viés é meu. (VPE6)

Eu separei os dois artigos para eles lerem. Separei os parágrafos bem parecidos [em termos de tamanho] de forma proposital para que eles pudessem ler um cada parágrafo. ISSO foi uma coisa que deu muito certo em uma outra regência que eu acompanhei com eles, porque eles ficam atentos para ver a hora que é eles...(VPE1)

A ideia era que cada aluno lesse um trecho do texto e daí retirar os conceitos físicos existentes e se não existissem ou eles não soubessem, o professor poderia inserir informações para ao final da leitura terem realmente entendido a reportagem. (TPE3)

Foi recorrente em nosso corpus a perspectiva de selecionar os trechos das reportagens selecionadas como forma de poderem explorar, principalmente, os conceitos físicos envolvidos. Houve um entendimento que para desenvolver um olhar crítico para os materiais selecionados é essencial que se aprofunde no conhecimento científico que está sendo abordado nas matérias (muitas vezes de maneira simplificada ou equivocada).

$E$ a partir destes buracos nas reportagens pensei em interferir com algumas informações e em alguns casos raciocinar com os alunos sobre as afirmações que o jornal ia fazendo (TPE3)

Por exemplo no trecho "Pesquisadores nos EUA usam fotos aéreas que detectam variação de temperatura em cidades para desenvolver projetos contra pontos críticos de calor" poderia ser problematizado as afirmações presentes, o sentido da problematização está em arrancar conceitos científicos do texto, para acompanhar o texto tendo uma base de raciocínio físico, entendendo com isso o problema apresentado pelos jornais, tanto quanto as causas do fenômeno, para a partir deste entendimento do porque as ilhas de calor ocorrem, os alunos pudessem desenvolver soluções para elas (TPE3) 
PE3 defende como objetivo central a possibilidade de os próprios alunos pensarem em soluções para o problema levantado (ilhas de calor). Esta perspectiva de tomada de decisões é algo que tem sido valorizado em perspectivas que encaram o ensino de ciências como meio de preparar os cidadãos e cidadãs para atuarem no mundo do qual fazem parte. Contudo, a licencianda apresenta uma ideia de problematização diferente da proposta por Freire, que busque a ampliação da consciência política dos alunos. Para ela a problematização do texto selecionado restringiu-se a aprofundar os conceitos físicos que não foram claramente apresentados.

\section{Problematização da Ciência}

O licenciando PE1 discutiu com seus alunos os possíveis desdobramentos sociais relacionados à inauguração do acelerador de partículas Sirius.

Após a leitura do texto, foi proposto debate para problematizar qual a importância do desenvolvimento de linhas de pesquisas e possíveis aplicações (TPE1)

Este extrato, e a leitura de sua análise como um todo, indica que PE1 buscou problematizar as relações entre o desenvolvimento de um empreendimento científico e as organizações sociais. Isto é, como a sociedade de maneira geral poderia ter benefícios com o desenvolvimento da ciência.

O licenciando PE2 tinha como um dos principais objetivos de sua regência problematizar o mito do gênio, particularmente a partir da imagem projetada de Einstein nos materiais de mídia.

Aí comecei a problematizar essa ideia de que a ciência é linear e que acontece sem nenhum erro, e que as coisas acontecem cronologicamente uma em seguida da outra, tudo certinho, que é uma visão muito errada que a gente tem de ciência, assim como endeusar os cientistas. Aí contei um pouco da história do Einstein. Falei também que a matemática que foi desenvolvida na teoria da relatividade geral foi desenvolvida por um professor de matemática 
dele e não foi exatamente ele que fez. Ele precisava de uma geometria nova e precisava de ajuda. Não foi ele que desenvolveu. Não tirando o mérito dele também. (VPE2).

Consideramos um resultado interessante da análise de nosso corpus a consideração de dois licenciandos, PE3 e PE5, sobre como a mídia em vídeo é mais interessante, de acordo com eles, para trabalhar com os estudantes do ensino médio.

Todos os alunos prestaram atenção. Eu pensei que não prestariam se eu usasse as notícias como mídia basilar. Se eu lesse todas acho que não prestariam atenção. Tanto que quando li alguns trechos percebi eles conversando um pouco ainda. Aí, depois que eu comecei a dar aula, aí começaram a prestar atenção. No vídeo [refere-se à reportagem televisiva sobre choque térmico e a síndrome de Bell] todo mundo tava prestando atenção. Eu acho mais interessante trabalhar com vídeo porque hoje em dia é muito mais chamativo para o aluno, youtube....raramente você encontra um aluno que lê notícias. É meio que um empecilho para muitos alunos ler alguma coisa na aula. Não que eles não leiam. Eles são alunos aqui do IF, então o que você pedir para eles fazerem vão fazer. Mas eu acho interessante trabalhar com mídias mais interativas (VPE5, grifos nossos).

Usar materiais de mídia em forma de textos é difícil no ensino médio, facilmente a atenção é perdida e os alunos na minha regência até começaram a ler, mas com o decorrer da aula, teve um momento que se recusaram a continuar, e eu prossegui. Talvez usar mídia em vídeo chamasse mais a atenção do aluno e portanto seja mais eficaz ou viável e até mais fácil de mantê-los focados na aula (TPE3).

\section{Seleção de conhecimentos Científicos}

\section{Seleção de conteúdos científicos tradicionais contextualizados}

A maior parte dos licenciandos abordaram conhecimentos clássicos da física, que encontramos há décadas nos currículos escolares de física. A licencianda 
PE3 selecionou o tema de ilhas de calor, tendo abordado conceitos como trocas de calor, temperatura e albedo. O licenciando PE4 selecionou conceitos como corrente elétrica, tensão elétrica e resistência para abordar o tema de "gatos de luz". O licenciando PE7 trabalhou o conceito de atrito a partir da proposição de uma nova camisinha autolubrificante. A licencianda PE8 abordou o conceito de entropia, fazendo relações com o cozimento de um ovo, com a teoria do Big Bang e com o conceito de tempo. Por fim, a licencianda PE9 analisou junto com seus alunos falas de narradores esportivos a partir das leis de Newton.

\section{Seleção de conteúdos científicos não tradicionais}

Dentre os nove licenciandos que participaram da disciplina de PE1 até o fim, consideramos que quatro selecionaram conteúdos não tradicionais, isto é, selecionaram conhecimentos que normalmente não figuram nos currículos escolares tradicionais. Dentre esses quatro, apenas PE1 aborda um tema contemporâneo envolvendo a ciência: a inauguração do acelerador de partículas Sirius. De acordo com PE1 a seleção do tema se deu, justamente, pela ampla e recente divulgação do Sirius na mídia:

Ele teve a inauguração dia 14/10. Então, fazia pouquíssimo tempo. Eu tava apostando que, sei lá, que apareceu no twiter deles, eu tava torcendo para que eles tivessem tropeçado nessa notícia. Das 5 turmas que eu acompanhei, em 3 tiveram alunos que viram essa notícia. Então foi legal falar de algo bem recente. (VPE1)

Outros dois licenciandos, PE5 e PE6, selecionaram conhecimentos científicos clássicos, mas com abordagens interdisciplinares que os levaram à seleção de conhecimentos científicos não tradicionais no ensino de física. PE5 trabalhou conceitos como temperatura e trocas de calor para discutir "bioenergética e choque térmico".

O porquê deu ter escolhido choque térmico e bioenergética dá-se, além do já dito, por uma vontade minha de trabalhar com um assunto da física que tratasse da saúde e fosse multidisciplinar (TPE5). 
[...] comecei a aula fazendo uma rápida revisão (Lei Zero, Trocas de Calor e conceito de calor x temperatura) [...] A partir disso, comecei a introduzir o que seria o "choque térmico" [...] Em seguida, comecei a me aprofundar na biologia do processo, explicando como que nosso corpo troca calor com ambiente, porque somos um animal que conserva a temperatura constante (homeotérmico) e por que outros animais, não (heterotérmicos). A partir daqui fui mostrando as diferenças e cuidados que uma criança, jovem e adulto devem ter. Também, falei do metabolismo, um pouquinho de evolução (para explicar juntamente com a física) por que a taxa de metabolismo basal de animais com menos espaço (menos massa e volume) é maior do que as dos maiores (VPE5)

O licenciando PE6 trabalhou conceitos como densidade e pressão de maneira interdisciplinar com conceitos das geociências relacionados à composição das camadas inferiores do planeta, placas tectônicas etc.

Inicialmente contextualizei a turma para a atividade que viria a ser realizada e comecei com a seguinte sequência de ideias: composição das camadas inferiores do planeta, movimentação e resultados que implicam a movimentação do manto, bem como explorei a concepção de densidade e como ela se faz importante neste momento; entramos em tectônicas globais e correlacionamos a sismicidade com a disposição das placas tectônicas (TPE6)

PE6 enfatiza, no entanto, que trabalhou esses conceitos a partir da interação com seus alunos durante o desenvolvimento de sua regência.

Conteúdos eu deixei em branco [no planejamento da aula] porque eu pensei assim: eu to levando muita coisa que foge de currículo. Nada mais justo que não limitar o conteúdo pra trabalhar. Então eu fui comentando a partir das perguntas e comentários que a gente foi construindo. Tanto que eu não tive conceitos específicos. Eu trabalhei um pouco de densidade, pressão, geociência também (VPE6). 
Já o licenciando PE2 trabalhou, principalmente, o paradoxo dos gêmeos. Além disso, abordou alguns episódios históricos como forma de problematizar o mito do gênio projetado sobre a figura de Einstein.

Aí comecei a problematizar essa ideia de que a ciência é linear e que acontece sem nenhum erro, e que as coisas acontecem cronologicamente uma em seguida da outra, tudo certinho, que é uma visão muito errada que a gente tem de ciência, assim como endeusar os cientistas. Aí contei um pouco da história do Einstein. Falei também que a matemática que foi desenvolvida na teoria da relatividade geral foi desenvolvida por um professor de matemática dele e não foi exatamente ele que fez. Ele precisava de uma geometria nova e precisava de ajuda. Não foi ele que desenvolveu. Não tirando o mérito dele também (VPE2).

\subsubsection{Interpretações a partir das categorizações: construindo um metatexto}

Assim como em EDC, a análise do corpus referente à disciplina de PE1 indica que houve pouca confrontação entre os materiais de diferentes meios de comunicação selecionados pelos licenciandos. Em paralelo à dificuldade em confrontar os materiais midiáticos, entendemos que houve descrições pobres dos meios de comunicação dos quais foram selecionados os materiais analisados pelos grupos. Em geral, os grupos se limitaram a apresentar o título das reportagens selecionadas e onde foram publicadas. Este descompromisso em descrever em detalhes os materiais selecionados e confrontar diferentes perspectivas sobre um mesmo tema se fez presente, no limite, nas produções de PE2 e PE4 que sequer indicaram quais foram os materiais midiáticos selecionados.

Nossa análise indicou, também, que os licenciandos focaram, sobretudo, no ensino de conceitos científicos, tendo apresentado poucas problematizações da mídia. Entendemos que os licenciandos encararam a inserção da mídia no ensino de física como uma ferramenta didática para o ensino de física. Em outras palavras, a formação crítica para a mídia foi um 
objetivo secundário dos professores em formação. Foram feitas algumas considerações sobre a dinâmica de funcionamento da mídia, como sua não neutralidade e, principalmente, o processo de simplificação pelo qual a linguagem da ciência passa ao ser publicada na mídia. Contudo, na descrição das aulas fica claro que o foco principal era exclusivamente o ensino de conceitos científicos e de suas relações com contextos específicos.

Diferente de EDC, percebe-se que os conteúdos científicos selecionados na disciplina de PE1 foram mais próximos daqueles clássicos que normalmente estão presentes nos currículos de física, tais como leis de Newton, Calor e Temperatura, corrente e tensão elétrica, atrito e entropia. Isto se deve, em nossa interpretação, pelas tensões geradas entre as proposições dos licenciandos e as condições concretas nas quais estagiaram. Os licenciandos têm que negociar com as instituições e professores que os recebem nos estágios. Com isto, a opção por conteúdos tradicionais da física faz parte desta negociação, a depender do currículo da escola e a abertura dada pelo professor que recebe o estagiário. Contudo, assim como em EDC, percebe-se que a seleção desses conteúdos se deu de maneira contextualizada: conceito de atrito sendo trabalhado a partir da construção de uma camisinha autolubrificante; entropia relacionada ao cozimento de um ovo; as leis de Newton em narrações esportivas; conceitos de calor e temperatura em problemas reais como a concentração urbana e a morte de pessoas por hipotermia; conceitos de corrente e tensão elétrica para discutir os "gatos de luz" etc. 


\section{Considerações Finais}

A educação científica é marcada por diversas tensões. Debater seus fundamentos e motivações não pode implicar uma busca irrealizável por formas pré-estabelecidas de ensinar ciências. Os jargões e slogans da nossa área precisam ser problematizados e contextualizados. O termo Alfabetização Científica, por exemplo, quando considerado apenas como um slogan pode ser nocivo a ponto de tornar-se um jargão sem significado algum. Por isso, acreditamos que o uso deste termo deve vir, sempre, acompanhado de uma visão educacional explícita e uma visão de ciência igualmente explícita. O sentido da $\mathrm{AC}$ não deve estar no termo em si, mas na maneira como o usamos em nossas pesquisas, currículos, ou em nosso discurso de maneira geral.

Reconhecer que o debate sobre AC está inserido em uma série de tensões intrínsecas à educação científica implica considerar que existe uma necessidade constante de diálogo e contextualização sobre esta temática. Defendemos que este constante diálogo deve se dar a partir de problemas e conflitos que estão relacionados, principalmente, aos desafios da formação de pessoas pertencentes ao seu tempo, que busquem a compreensão do mundo que as cercam, sobretudo para que possam participar de maneira crítica e democrática de decisões em que estão implicadas. Assim, uma das questões essenciais que deve perpassar os diálogos sobre a $\mathrm{AC}$, e que faz parte das tensões a que nos referimos, é a seguinte: Quais são os problemas emergentes do mundo hoje?

Entendemos que um dos problemas emergentes do mundo hoje está relacionado às relações das pessoas com a mídia e através da mídia. As Fake News, por exemplo, têm se colocado como grande desafio à democracia e às possibilidades de tomadas de decisões bem informadas e fundamentadas. A mídia, de maneira geral, está no âmago da organização social atual. Informamo-nos, relacionamo-nos, temos acesso às histórias, hegemônicas ou 
não, através da mídia. Temos possibilidades de nos expressarmos através da mídia.

Se estas questões - por sua amplitude e complexidade - parecem distantes dos desafios enfrentados por educadores e educadoras em ciências, esta é somente uma falsa impressão. A mesma sociedade marcada pelas Fake News é a que acompanha movimentos de negação das ciências, como o movimento anti-vacina, os grupos terraplanistas e os que negam o aquecimento global. Se concepções ingênuas de ciências foram até o momento interpretadas como "epistemologias espontâneas" manifestadas por estudantes, agora fica claro que as mesmas são fruto de embates sociais.

Portanto, como embate social, é fundamental que essas questões sejam inseridas em iniciativas educacionais sistematizadas. Como educadoras e educadores, temos o dever de preparar os cidadãos e cidadãs para lidarem de forma crítica e criativa com as tecnologias de informação e com a mídia, para que possam identificar ideologias, mensagens subentendidas, posicionamentos, disputas de poder etc, em busca da composição de suas próprias visões de mundo e de atuações democráticas em busca de mudanças radicais na sociedade.

A partir da consideração de que a educação científica deve ser um meio e não fim em si mesma, estando relacionadas a objetivos formativos que considerem problemas sociais emergentes, defendemos a inserção da mídia em aulas de física. Concordamos com as indicações da literatura, que indicam que a formação de professores é condição sine qua non para o projeto de aproximação das perspectivas da educação para as mídias e o ensino de ciências.

A principal proposição desta tese é que os materiais de mídia devem ser problematizados nas aulas de Física, de modo que os estudantes sejam capazes de identificar vieses e interesses na produção midiática, reconhecendo sua não neutralidade. Para o exercício de uma leitura crítica da mídia defendemos como condição a comparação entre diferentes produções sobre um mesmo tema, para que seja possível compor uma visão 
mais complexificada e que identifique, eventualmente, tensões entre diferentes perspectivas. Ser capaz de criticar as narrativas da mídia passa por reconhecer, como defendia Paulo Freire, que a produção midiática não é boa e nem má em si mesma, mas que potencialmente serve a interesses. Assim, é fundamental questionar a serviço "do quê" e a serviço "de quem" as mídias estão.

A aproximação entre a educação para as mídias e o ensino de ciências deve buscar, além de reflexões críticas e analíticas sobre os meios de comunicação e as possibilidades de atuação crítica e criativa através das mídias, a problematização do próprio conhecimento científico e de suas relações com o desenvolvimento tecnológico e com a organização social de maneira mais ampla. Entendemos ser fundamental na problematização da ciência veiculada na mídia a discussão de características epistemológicas do conhecimento científico, de modo que sejam superadas visões estereotipadas da ciência, tais como a "mitologia dos resultados" que representa o fazer científico apenas por seus produtos, a crença em um método científico único e universal, o "mito do gênio" que identifica apenas grandes nomes como Einstein, Newton, Galileu etc, como responsáveis pela construção de conhecimento científico, dentre outras. Igualmente importante é que sejam exploradas as relações entre ciência, tecnologia, sociedade e meio ambiente nas problematizações dos materiais midiáticos sobre ciência.

Entendemos que a inserção da mídia em aulas de física deve ir além do mero uso instrumental de materiais midiáticos em sala de aula. A aproximação entre a Educação para as Mídias e o Ensino de Ciências deve compor estratégias para a constituição de olhares críticos tanto da Mídia quanto da Ciência e, em última instância, um olhar crítico para o mundo onde essas relações se dão a partir de diferentes tensões e através de disputas de poder.

Ao desenvolvermos as duas disciplinas descritas e analisadas nesta tese, percebemos que a aproximação entre as perspectivas da educação para as mídias e o ensino de ciências enfrenta uma série de tensões entre si e, 
principalmente, tensões entre os fundamentos educacionais e as condições concretas nas quais os professores em formação estão inseridos. Os materiais que compõem o corpus da disciplina de EDC indicou que embora os licenciandos tenham, em geral, desenvolvido análises críticas dos materiais selecionados, não conseguiram propor planos de aulas que buscassem a problematização das questões levantadas em suas críticas. Houve uma busca sistemática por aprofundar os conhecimentos físicos divulgados de forma superficial por materiais de mídia. $O$ foco no conhecimento físico foi ainda mais latente na análise dos materiais que compõem o corpus da disciplina PE1. O contexto do estágio supervisionado, no qual os licenciandos têm que negociar suas práticas e objetivos educacionais com as escolas e professores que os recebem necessariamente implicam nas abordagens que, ao final, são concretizadas. Esta é uma relação dialética entre as propostas teóricas que são feitas na universidade e o contexto prático da sala de aula.

A partir da análise dos materiais desenvolvidos pelos professores em formação, concluímos que faltaram atividades direcionadas, nas quais eles pudessem analisar mais materiais midiáticos de variados temas, de preferência sugeridos pelos próprios professores, confrontando materiais, pesquisando de maneira metódica a constituição dos meios de comunicação do Brasil e do mundo, já que a falta de caracterização dos materiais selecionados pelos licenciandos mostra que esta foi uma prática pouco explorada nas disciplinas ministradas. Não basta dizer que a confrontação de materiais e a caracterização da mídia são fundamentais para o desenvolvimento de posturas críticas, é necessário criar condições concretas para que isto seja possível.

Por fim, destacamos nossa tentativa de aproximar algumas perspectivas da educação para as mídias e a história da ciência. Julgamos que essa aproximação pode ser profícua, possibilitando a exploração de diversos materiais de mídia sobre episódio históricos que marcaram o desenvolvimento da ciência e a humanidade de maneira geral, como o episódio do acidente nuclear de Chernobyl, o lançamento de bombas 
atômicas sobre Hiroshima e Nagasaki, a ida do ser humano à Lua etc. Compreender como as narrativas da mídia foram construídas para contar esses episódios possibilita o exercício crítico tanto da mídia como das condições de produção da ciência. Para isto, é necessário que os textos midiáticos publicados em diferentes sejam confrontados com estudos de historiadores que remontem o contexto no qual foram produzidos. Indicamos que trabalhos futuros explorem de maneira mais sistemática essa aproximação entre educação para as mídias e a história da ciência no ensino. 


\section{Referências}

AULER, Décio; DELIZOICOV, Demétrio. Alfabetização CientíficoTecnológica para quê? Revista Ensaio - Pesquisa em Educação em Ciências. V. 3, n. 1, 2001. pp.1-13

BASILIO, Sofia. A ideologia em materiais de divulgação científica: um estudo da imagem de Einstein em discursos sobre as ondas gravitacionais. Dissertação de Mestrado. Programa de Pós-Graduação Interunidades em Ensino de Ciências da USP, 2018.

BELLONI, Maria. L. O que é mídia-educação. $3^{\text {a }}$ edição revista. Campinas, SP: Autores Associados, 2009.

BERTOLLI, Claudio. Elementos fundamentais para a prática do jornalismo científico. Disponível em: http://www.bocc.ubi.pt/pag/bertolli-claudio-elementosfundamentais-jornalismo-cientifico.pdf

BÉVORT, Evélyne.; BELLONI, Maria. Mídia-educação: conceitos, história e perspectivas. Educ. Soc., Campinas, v. 30, n. 109, 2009. pp. 1081-1102.

BOURDIEU, P. Sobre a Televisão. Tradução Maria Lúcia Machado. Rio de Janeiro:Jorge Zahar Ed., 1997.

BRASIL. Lei de Diretrizes e Bases da educação nacional. Lei n ${ }^{\circ}$ 9.394/96, de 20 de dezembro de 1996. Disponível em: http://www.planalto.gov.br/ccivil 03/leis/19394.htm

BRASIL. Relatório Final da Pesquisa Brasileira de Mídia - 2016. Presidência da República/ Secretaria de Comunicação Social (SECOM). Empresa Responsável: IBOPE inteligência. Brasília - DF. 2016. Disponível em: $\quad$ http://www.secom.gov.br/atuacao/pesquisa/lista-de-pesquisas-quantitativas-equalitativas-de-contratos-atuais/pesquisa-brasileira-de-midia-pbm-

2016.pdf/@@download/file/Pesquisa\%20Brasileira\%20de\%20M\%C3\%ADdia\%20\%20PBM\%202016.pdf 
BRASIL. Relatórios Econômicos OCDE. 2018. Disponível em: https://www.oecd.org/eco/surveys/Brazil-2018-OECD-economic-survey-overview-

Portuguese.pdf

BYBEE, Rodger. Towards an Understanding of Scientific Literacy. In. GRAEBER, W., BOLTE, C. (Eds) Scientific Literacy. Kiel: IPN, 1997.

CACHAPUZ, António; GIL-PEREZ, Daniel; CARVALHO, Anna Maria; PRAIA, João. V. VILCHES, Amparo. A Necessária renovação do ensino das ciências / António Cachapuz...[et al.], (organizadores). — São Paulo : Cortez, 2005.

CALDAS, Graça. Mídia, escola e leitura crítica do mundo. Educação \& Sociedade, Campinas, v. 27, n. 94, 2006. p.117-130

CARDOSO, Danilo; GURGEL, Ivã; NORONHA, André; WATANABE, Graciella. Texto Jornalístico sobre Ciência: uma análise do discurso sobre a natureza da ciência. Revista Alexandria. V. 8, n.3, 2015. pp. 229-251.

CARVALHO, Graça. Literacia Científica: conceitos e dimensões. In: Azevedo, F. \& Sardinha, M.G. (coord.) Modelos e Práticas em Literacia. Lisboa: Lidel, 2009. pp. 179-194.

CHASSOT, Attico. Alfabetização científica: uma possibilidade para a inclusão social. Revista Brasileira de Educação. V.22, 2003.

CHOMSKY, Noam. Mídia: Propaganda política e manipulação. Tradução Fernando Santos. São Paulo: Editora WMF Martins Fontes, 2013.

DEBOER, George. Scientific Literacy: Another Look at Its Historical and Contemporary Meanings and Its Relationship to Science Education Reform. Journal of Research in Science Teaching. V.37, n. 6, 2000. pp. 582-601.

DELIZOICOV, Demétrio.; ANGOTTI, José; PERNAMBUCO, Marta. Ensino de Ciências: Fundamentos e Métodos. Editora Cortez, São Paulo, 2002. 
EISENSTAEDT, J. \& VIDEIRA, A. A Relatividade Geral verificada: o eclipse de Sobral de 29/05/1919; In: Einstein e o Brasil; Orgs: MOREIRA, I. \& VIDEIRA, A. Rio de Janeiro: Ed. UFRJ, 1995.

EINSTEIN (1911). Sobre a Influência da Gravidade na Propagação da Luz. In: LORENTZ, H.A.; EINSTEIN, A. \& MINKOWSKI, H.: O Princípio da Relatividade. Col. Textos Fundamentais da Física Moderna, vol.I, 3a ed. Trad. Mário José Saraiva. Lisboa: Fundação Calouste Gulbenkian; 1983, pp.127-140.

EINSTEIN, Albert (1916). Sobre Os Fundamentos da Teoria da Relatividade Geral. In:LORENTZ, H.A.; EINSTEIN, A. \& MINKOWSKI, H.: O Princípio da Relatividade. Col. Textos Fundamentais da Física Moderna, vol.I, 3a ed. Trad. Mário José Saraiva. Lisboa: Fundação Calouste Gulbenkian; 1983, pp.141-214.

EINSTEIN, Albert. Notas Autobiográficas; Ed. Comemorativa/ traduzida e anotada por Paul Arthur; tradução de Aulyde Soares Rodrigues. - Rio de Janeiro: Nova Fronteira, 1982.

FENTON, Natalie; FREEDMAN, Des. Democracia fake, más notícias. In: Comunicação \& Educação. Ano XXIII, n.1, 2018. pp. 107 - 126.

FOSTER, Alan. The Times and Appeasement: the second phase. In: Journal of Contemporary History. V.16, 1981. pp. 441-465.

FREIRE, Paulo. Pedagogia da indignação: cartas pedagógicas e outros escritos. 1. ed. São Paulo: Paz e Terra, 2014.

FREIRE, Paulo. Extensão ou Comunicação. Editora Paz e Terra, 2015.

FREIRE, Paulo; GUIMARÃES, Sérgio. Educar com a mídia: novos diálogos sobre educação. São Paulo: Paz e Terra, 2011. 238p.

FREIRE, Paulo; GUIMARÃES, Sérgio. Sobre educação: Diálogos - Volume 2. Rio de Janeiro: Paz e Terra, 1984. 
FREIRE, Paulo; MACEDO, Donaldo. Alfabetização: leitura do mundo, leitura da palavra. Editora Paz e Terra, 1990.

FREIRE, Paulo; SHOR, Ira. Medo e Ousadia. Editora Paz e Terra, 2011.

GADOTTI, Moacir. Prefácio. In: Paulo Freire. Educação e Mudança. $12^{\text {a }}$ Edição. Paz e Terra. Rio de Janeiro, 1979.

GIL-PÉREZ, Daniel; PEÑA, Amparo Vilches. Una Alfabetización Científica para el siglo XXI: Obstáculos y Propuestas de Actuación. Investigación en la Escuela. V.43, pp.1-14, 2001.

GIL-PÉREZ, D.; MONTORO, I. F.; ALÍS, J. C.; CACHAPÚZ, A.; PRAIA, J. Para uma imagem não deformada do trabalho científico. Revista Ciência \& Educação, v.7, n.2, p.125-153, 2001.

GUERRA, Andrea. Considerações sobre a Reforma da Lei 9394, que estabelece as diretrizes e bases da educação nacional. Caderno Brasileiro de Ensino de Física, V. 34, n.1, 2017. pp.1-5.

GURGEL, Ivã; PIETROCOLA, Maurício; WATANABE, Graciella. The role of cultural identity as a learning factor in physics: a discussion through the role of science in Brazil. Cultural Studies of Science Education (online), v. 11, p. 349-370, 2016.

HANSON, Norwood. Observação e Interpretação. In: Morgenbesser, S. (Org.). Filosofia da ciência. Tradução L. Hegenberg \& O. S. da Mota. 3. ed. São Paulo: Cultrix, 1979.

HODSON, Derek. Realçando o papel da ética e da política na educação científica: algumas considerações teóricas e práticas sobre questões sociocientíficas. In: Questões sociocientíficas: fundamentos, propostas de ensino e perspectivas para ações sociopolíticas / Dália Melissa Conrado, Nei Nunes Neto (Org.) - Salvador: EDUFBA, 2018. 570 p.

JARMAN, Ruth; McCLUNE, Billy. Developing Scientific Literacy: Using News Media in the Classroom. Open University Press, New York, 2007. 
KELLNER, D.; SHARE, J. Educação para a leitura crítica da mídia, democracia radical e a reconstrução da educação. Educação \& Sociedade, Campinas, v. 29, n. 104, 2008. pp. 687-715.

KENNEFICK, Daniel. Not Only Because of Theory: Dyson, Eddington and the Competing Myths of the 1919 Eclipse Expedition, 2007. Disponível em: https://www.researchgate.net/publication/2224282 Not Only Because of Theory Dyson E ddington and the Competing Myths ofthe 1919 Eclipse Expedition

LAUGKSCH, Rudiger. Scientific Literacy: A Conceptual Overview. Science Education, V.84, n.1, 2000. pp.71-94.

LAZER, David et al. The Science of Fake News. In: Science. Policy Forum. V. 359, Issue. 3680, 2018. pp - 1094 - 1096. Disponível em: https://science.sciencemag.org/content/359/6380/1094

LUCA, T. História dos, nos e por meio de periódicos. In: PINKSY, Carla Bassanesi. Fontes Históricas. São Paulo: Contexto, 2008.

MARTINS, Isabel. Letramento Científico: Um diálogo entre Educação em Ciências e Estudos do Discurso. In: (Org.) Marinho, M. \& Carvalho, G. Cultura Escrita e Letramento. Belo Horizonte: Editora UFMG, 2010

MEDITSCH, Edurdo; FARACO, Mariana. O pensamento de Paulo Freire sobre Jornalismo e Mídia. Revista Brasileira de Ciências da Comunicação, V.XXVI, n.1, 2003. pp. 25-46.

MEDITSCH, Edurdo. Paulo Freire nas práticas emancipadoras da comunicação: ainda hoje, um método subutilizado no Brasil. In: Revista Latinoamericana de Ciencias de la Comunicación. V.13, n.25, 2017. pp. 132 -143 .

MILLAR, Robin; OSBORNE, Jonathan. (Eds.) (1998). Beyond 2000: Science education for the future (the report of a seminar series funded by the Nuffield Foundation). London: King's College London. 
MISSNER, M. Why Einstein Became Famous in America. In: Social Studies of Science, Vol. 15, N. 2, pp. 267-291, 1985.

NORRIS, Stephen; PHILLIPS, Linda. How literacy in its fundamental sense is central to scientific literacy. Science Education, V. 87, n. 2, 2003. pp. 224240

OCDE. Education at a Glance 2018. OECD indicators, OECD Publishing, Paris. 2018.2 Disponível em: http://download.inep.gov.br/acoes internacionais/eag/documentos/2018/EAG Relatorio na integra.pdf

PAIS, Abraham. Subtil é o senhor: vida e pensamento de Albert Einstein; tradução Fernando Parente e Viriato Esteves - Gradativa publicações, 1993.

PATY, Michel. (1993) Einstein Philosophe: la physique comme pratique philosophique. Collection Philosophie d'Aujourd'hui. Paris: Presses Universitaires de France, 1993, 584 p

PEZZO, Mariana. Ensino de Ciências e Divulgação Científica: Análise das Recontextualizações entre as Revistas Carta Capital e Carta na Escola. Dissetação, Centro de Educação e Ciências Humanas da Universidade Federal de São Carlos, 2011.

PEZZO, Mariana; PIERSON, Alice. Especificidades e complementaridade entre Ensino de Ciências e Divulgação Científica: reflexões a partir da análise mensal voltada à inserção das "atualidades" no ambiente escolar. IX Congreso Internacional sobre Investigación en Didáctica de las Ciencias, 2013. pp. 3093-3097.

PEZZO, Mariana. Olhares de Professores de Ciências em Formação sobre as Mídias, sua Inserção no Ensino e a Educação para as Mídias. Tese, Centro de Educação e Ciências Humanas da Universidade Federal de São Carlos, 2016. 
PINHEIRO, Rafaela. Leitura crítica da mídia à luz de Paulo Freire: Uma reação ao silenciamento de educandos e educadores na História da Educação In: Anais do XII EDUCERE: Formação de professores, complexidade e trabalho docente-. Curitiba: Champagnat, 1, pp. 25281-25297.

PRAZERES, Michelle. Educação não escolar de adultos e comunicação: um estado da arte 1999 a 2006. Revista e-curriculum, V. 5, n.1, 2009. Disponível em: https://revistas.pucsp.br/curriculum/article/view/3252

RENN, Jügen. (2007). Classical Physics in Disarray: The Emergence of the Riddle of Gravitation. In: Renn, J. (Ed.) The Genesis of General Relativity, Vol. 1, Einstein's Zurich Notebook: Introduction and source. Springer. pp. 21-80.

RIBEIRO, Renata. A.; KAWAMURA, Maria Regina. D. Ensino de Física e formação do espírito crítico: reflexões sobre o papel da divulgação científica. XI Encontro de Pesquisa em Ensino de Física, Curitiba, PR. Atas... Curitiba, PR: Sociedade Brasileira de Física, 2008.

RIGHETTI, Sabine. Ciência na Mídia: onde estão os estudos de pesquisadores brasileiros? In: ComCiência e divulgação científica / Carlos Vogt, Marina Gomes, Ricardo Muniz (Organizadores). - Campinas, SP: BCCL/UNICAMP, 2018. pp. 23-30.

ROBERTS, Douglas. Scientific Literacy/ Science Literacy. In: Sandra K.Abell and Norman G. Lerderman (Eds.) Handbook of Research on Science Education. Lawewncw Erlbaum Associetes, Publishers, Mahwah, Nex Jersey, London 2007.

ROBERTS, Douglas; BYBEE, Rodger. Scientific Literacy, Science Literacy, and Science Education. In: Sandra K.Abell and Norman G. Lerderman (Eds.) Second Handbook of Research on Science Education. Lawewncw Erlbaum Associetes, Publishers, Mahwah, Nex Jersey, London 2014. 
SANTOS, Wildson. Educação científica na perspectiva de letramento como prática social: funções, princípios e desafios. Revista Brasileira de Educação, V. 12, n. $36,2007$.

SASSERON, Lucia Helena; CARVALHO, Ana Maria Pessoa. Alfabetização científica: uma revisão bibliográfica. Investigações em Ensino de Ciências, V.16(1), 2011. pp. 59-77.

SPONSEL, A. Constructing a 'revolution in science': the campaign to promote a favourable reception for the 1919 solar eclipse experiments. In: The British journal for the history of science, V. 35, n. 4, p. 439-467, 2002.

STACHEL, John (2002a). The first two acts. In: Einstein from "B" to "Z". Einstein Studies, vol.9. Boston: Birkhäuser, 2002, pp.261-292.

STACHEL, John (2002b). The Rigidly Rotation Disk as the "Missing Link" in the History of General Relativity. In: Einstein from "B" to "Z". Einstein Studies, vol.9. Boston: Birkhäuser, 2002, pp.245-260.

STANLEY, M. An expedition to heal the wounds of war: the 1919 eclipse and Eddington as a Quaker adventurer. In: Isis V. 94, p. 57-89, 2003.

SUTTON, Clive. Ideas sobre la Ciencia e Ideas sobre el Lenguage. In: Alambique Didactica de las Ciencias Experimentales, n.12, 1997.

TEIXEIRA, Mônica. Pressupostos do jornalismo de ciência no Brasil. Em: MASSARANI, L., MOREIRA, I. \& BRITO, F. Ciência e Público: caminhos da divulgação científica no Brasil. Rio de Janeiro: Centro Cultural de Ciência e Tecnologia da UFRJ/ Editora UFRJ, 2002. p.133-142.

TRILLA, Jaume. Educação Formal e não-formal: pontos e contrapontos / Jaume Trilla, Ellie Ghanem; Valéria Amorim Arantes (Org.) - São Paulo: Sammus, 2008. - (Coleção pontos e contrapontos)

VIDEIRA, A. Einstein e o eclipse de 1919. Física na Escola, V. 6, n.1, 2005. 
ZIMMERMAN, C.; BISANZ, G. L. \& BISANZ, J. Science at the supermarket: What's in print, experts' advice and students' need to know. In: Annual meeting of the National Association for Research in Science Teaching, - Boston, MA, 1999.

YORE, Larry; BISANZ, Gay; HAND, Brian (2003) Examining the Literacy Component of Science Literacy: 25 Years of Language Arts and Science Research. International Journal of Science Education, V.25, n.6, 2003. 


\section{ANEXOS}




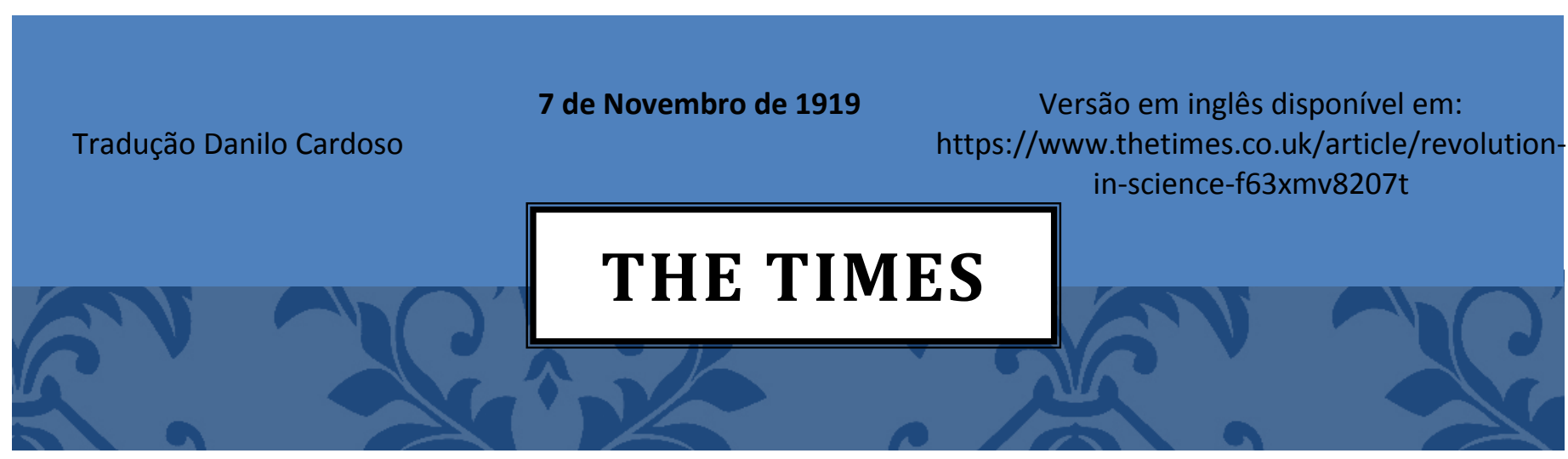

\section{REVOLUÇÃO NA CIÊNCIA}

\section{Novas ideias do universo: ideias newtonianas caídas}

Ontem à tarde nas salas da Royal Society, em uma sessão conjunta da Royal Society e Royal Astronomical Society, foram discutidos os resultados obtidos por observadores britânicos do eclipse solar total de 29 de maio.

O maior interesse possível havia sido despertado nos círculos científicos pela esperança de que teorias rivais sobre um problema físico fundamental fossem postas à prova, e houve um grande comparecimento de astrônomos e físicos. Foi amplamente aceito [generally accepted] que as observações foram decisivas na verificação da predição do famoso físico Einstein. Tais observações foram declaradas pelo Presidente da Royal Society como o evento científico mais proeminente desde a descoberta da existência prevista do planeta Netuno. Mas havia uma diferença de opinião sobre a ciência estar meramente diante de um fato novo e não explicado, ou de uma teoria que revolucionaria completamente os fundamentos aceitos da física.

Sir Frank Dyson, o astrônomo real, descreveu o trabalho das expedições à Sobral, no norte do Brasil, e à ilha do Príncipe, na costa oeste da África. Em cada um desses lugares, se o tempo fosse propício no dia do eclipse, seria possível tirar um número total de fotografias do sol obscurecido e de um número de estrelas brilhantes em sua vizinhança imediata. $\mathrm{O}$ objeto desejado era verificar se a luz vinda dessas estrelas, passando pelo Sol, vem diretamente a nós como se o Sol não estivesse lá, ou se há uma deflexão devido a sua presença que poderia aparecer nas placas fotográficas como uma distância mensurável das posições teóricas das estrelas. Dyson explicou em detalhes o aparato que havia sido empregado, as correções que precisavam ser feitas para vários fatores perturbadores e os métodos pelos quais a comparação entre as posições teóricas e observadas foram feitas. Ele convenceu a reunião de que os resultados eram definitivos e conclusivos. A deflexão ocorreu, e as medições mostraram que a dimensão da deflexão estava em estreita concordância com o grau teórico previsto por Einstein, em oposição à metade desse grau, que se seguiria dos princípios de Newton. É interessante lembrar que Sir Oliver Lodge, falando na Royal Institution em fevereiro passado, também se aventurou em uma previsão. Duvidava que a deflexão fosse observada, mas estava confiante de que se 
ocorresse, seguiria a lei de Newton e não a de Einstein.

O Dr. Crommelin e o Professor Eddington, dois dos observadores de fato [actual observers], acompanharam o Astrônomo Real e deram relatos interessantes de seu trabalho, confirmando, em todos os sentidos, as conclusões gerais que haviam sido enunciadas.

\section{"MOMENTOUS}

\section{PRONOUNCEMEN}

\section{T" \\ IImportante}

\section{momento}

\section{pronunciamento]}

Até agora o assunto estava claro, mas quando a discussão começou ficou evidente [plain] que o interesse científico se concentrou mais na relevância [bearings] teórica dos resultados do que nos resultados em si. Até mesmo o presidente da Royal Society, ao afirmar que havia acabado de escutar "um dos mais importantes, se não o mais importante, pronunciamentos do pensamento humano", teve que confessar que ninguém ainda havia conseguido declarar em linguagem clara o que a teoria de Einstein realmente era. Foi aceito, no entanto, que Einstein, com base em sua teoria, fizera três previsões. A primeira, relacionada ao movimento do planeta Mercúrio, havia sido verificada. A segunda, relacionada à existência e ao grau de deflexão da luz ao passar pela esfera de influência do sol, foi agora verificada. Quanto à terceira, que dependia de observações espectroscópicas, ainda havia incerteza. Mas ele estava confiante de que a teoria de Einstein deve agora ser levada em conta, e que nossas concepções do tecido [fabric] do universo devem ser fundamentalmente alteradas.

Nesse estágio, Sir Oliver Lodge, cuja contribuição para a discussão havia sido ansiosamente esperada, saiu da reunião.

Oradores [speakers] subsequentes se juntaram para parabenizar os observadores e concordaram em aceitar seus resultados. Mais de um, no entanto, incluindo o professor Newall, de Cambridge, hesitou quanto à extensão total das inferências que haviam sido tiradas e sugeriu que os fenômenos poderiam ser devidos a uma atmosfera solar desconhecida ainda maior do que se supunha e com propriedades desconhecidas. Nenhum orador conseguiu dar uma clara declaração não-matemática da questão teórica.

\section{SPACE}

\section{“WARPED” [Espaço}

\section{"Deformado"]}

Posto de maneira mais geral pode ser descrito da seguinte forma; os princípios newtonianos pressupõem que o espaço é invariável, que, por exemplo, os três ângulos de um triângulo sempre são iguais e devem ser iguais a dois ângulos retos. Mas esses princípios realmente se baseiam na observação de que os ângulos de um triângulo são iguais a dois ângulos retos e que um círculo é realmente circular. Mas há certos fatos físicos que parecem lançar dúvidas sobre a universalidade dessas observações, e sugerem que o espaço pode adquirir uma curvatura [twist] ou deformação [warp] em certas circunstâncias, como, por exemplo, sob 
a influência da gravitação, um deslocamento ligeiro em si mesmo e aplicável aos instrumentos de medida, bem como às coisas medidas. A doutrina de Einstein [Einstein doctrine] é que as qualidades do espaço, até então consideradas absolutas, são relativas às suas circunstâncias. Ele extraiu a inferência de sua teoria de que, em certos casos, a medição real da luz mostraria os efeitos da deformação [warping] em um grau que poderia ser previsto e calculado. Suas previsões em dois dos três casos foram verificadas agora, mas a questão permanece em aberto sobre se as verificações provam a teoria da qual as previsões foram deduzidas. 


\section{THE TIMES}

\section{Einstein sobre sua teoria}

\section{Tempo, Espaço e Gravitação}

Respondo com satisfação ao pedido do correspondente de escrever algo para o The Times sobre a Teoria da Relatividade.

Depois da lamentável ruptura nas antigas [former] relações internacionais existentes entre os homens da ciência, é com alegria e gratidão que aceito esta oportunidade de comunicação com astrônomos e físicos ingleses. Foi de acordo com a alta e altiva [pround] tradição da ciência inglesa que os cientistas ingleses deviam ter dado seu tempo e trabalho e que as instituições inglesas deveriam ter fornecido os meios materiais para testar uma teoria que havia sido completada e publicada no país de seus inimigos no meio da guerra.

Embora a investigação da influência do campo gravitacional solar sobre os raios de luz seja uma questão puramente objetiva, não deixo de estar muito contente [glad] em expressar meus agradecimentos pessoais aos meus colegas ingleses neste ramo da ciência; pois sem a ajuda deles eu não teria obtido a prova da dedução mais vital da minha teoria.

Existem vários tipos de teorias na física. A maioria delas é construtiva. Estas tentam construir uma imagem de fenômenos complexos a partir de alguma proposição relativamente simples. A teoria cinética dos gases, por exemplo, tenta referir-se ao movimento molecular das propriedades mecânicas, térmicas e de difusão dos gases. Quando dizemos que entendemos um grupo de fenômenos naturais, queremos dizer que encontramos uma teoria construtiva que abrangem esses fenômenos.

\section{THEORIES OF}

\section{PRINCIPLE [Teoria}

\section{de princípios]}

Mas, além desse grupo de teorias mais recorrente [most weighty], há outro grupo que consiste no que chamo de teorias de princípio. Teorias de princípio empregam o método analítico, não o sintético. Seu ponto de partida e fundamento não são constituintes hipotéticos, mas propriedades gerais de 
fenômenos observados empiricamente, princípios dos quais são deduzidas fórmulas matemáticas de tal tipo que se aplicam a todos os casos que se apresentam. A termodinâmica, por exemplo, parte do fato de que o movimento perpétuo nunca ocorre na experiência comum, tenta deduzir disso, por processos analíticos, uma teoria que se aplicará em todos os casos. O mérito das teorias construtivas é sua abrangência [comprehensiveness], adaptabilidade e clareza, o mérito das teorias de princípio, sua perfeição lógica e a segurança de seu fundamento.

A teoria da relatividade é uma teoria de princípio. Para entendê-la, os princípios sobre os quais ela se baseia devem ser compreendidos. Mas, antes de afirmar isso, é necessário salientar que a teoria da relatividade é como uma casa com duas histórias separadas, a teoria da relatividade especial e a teoria da relatividade geral.

Desde a época dos antigos gregos, é bem conhecido que, ao descrever o movimento de um corpo, devemos nos referir a outro corpo. O movimento de um trem é descrito com referência ao solo, o de um planeta com referência ao conjunto total de estrelas fixas visíveis. $\mathrm{Na}$ física, os corpos aos quais os movimentos são espacialmente referenciados são denominados sistemas de coordenadas. As leis da mecânica de Galileu e Newton podem ser formuladas apenas usando um sistema de coordenadas.

O estado de movimento de um sistema de coordenadas não pode ser escolhido arbitrariamente se as leis da mecânica forem válidas (deve estar livre de rotações e de aceleração). O sistema de coordenadas empregado na mecânica é chamado de sistema inercial. O estado de movimento de um sistema inercial, no que diz respeito à mecânica, não se restringe por natureza a uma condição. A condição na seguinte proposição é suficiente: um sistema de coordenadas movendo-se na mesma direção e com a mesma velocidade que um sistema inercial é ele próprio um sistema inercial. A teoria da relatividade especial é, portanto, a aplicação da seguinte proposição a qualquer processo natural: "Todas as leis da natureza que sejam válidas em relação a um sistema de coordenadas $\mathrm{K}$ também devem ser válidas para qualquer outro sistema $\mathrm{K}^{\prime}$, desde que $\mathrm{K}$ e $\mathrm{K}$ ' estejam em movimento de translação uniforme".

O segundo princípio sobre o qual repousa a teoria da relatividade especial é o da constância da velocidade da luz no vácuo. A luz no vácuo tem uma velocidade definida e constante, independente da velocidade da sua fonte. Os físicos devem sua confiança nesta proposição à teoria da eletrodinâmica de Maxwell-Lorentz.

Os dois princípios que mencionei receberam forte confirmação experimental, mas não parecem ser logicamente compatíveis. A teoria da relatividade especial alcançou sua reconciliação lógica fazendo uma mudança na cinemática, isto é, na doutrina [doctrine] das leis físicas do espaço e do tempo. Tornou-se evidente que uma declaração da coincidência [coincidence] de dois eventos poderia ter um significado apenas em relação a um sistema de coordenadas, que a massa dos corpos e a taxa de movimento dos relógios devem depender do seu estado de movimento em relação às coordenadas.

\section{THE OLDER PHYSICS [A VELHA FÍSICA]}

Mas a física mais antiga, incluindo as leis do movimento de Galileu e Newton, conflitaram com a cinemática relativista que indiquei. Esta última deu origem a certas condições 
matemáticas generalizadas com as quais as leis da natureza teriam que confirmar se os dois princípios fundamentais eram compatíveis. A física teve que ser modificada. A mudança mais notável foi uma nova lei do movimento para pontos de massa em movimento muito rápidos, e isso logo veio a ser verificado no caso de partículas eletricamente carregadas. $\mathrm{O}$ resultado mais importante do sistema da relatividade especial dizia respeito à massa inerte de um sistema material. Ficou evidente que a inércia de tal sistema deve depender de seu conteúdo energético, de modo que fomos levados à concepção de que a massa inerte não era nada mais que energia latente. A doutrina da conservação da massa perdeu sua independência e se fundiu na doutrina da conservação da energia.

A teoria da relatividade especial, que era simplesmente uma extensão sistemática da eletrodinâmica de Maxwell e Lorentz, teve conseqüências que ultrapassaram a si mesma. A independência das leis físicas em relação a um sistema de coordenadas deve ser limitada a sistemas de coordenadas em movimento uniforme de translação em relação a um outro? $\mathrm{O}$ que tem a natureza a ver com os sistemas de coordenadas que propomos e com os seus movimentos? Embora seja necessário que nossas descrições da natureza empreguem sistemas de coordenadas que selecionamos arbitrariamente, a escolha não deve ser limitada de modo algum no que diz respeito ao seu estado de movimento. (Teoria da relatividade geral) Verificou-se que a aplicação desta teoria geral da relatividade estava em conflito com uma experiência bem conhecida, segundo a qual parecia que o peso e a inércia de um corpo dependiam das mesmas constantes (identidade de massas inerciais e gravitacionais). Considere o caso de um sistema de coordenadas que é concebido como estando em rotação estável em relação a um sistema inercial no sentido newtoniano. As forças que, relativamente a este sistema, são centrífugas, devem, no sentido newtoniano, ser atribuídas à inércia. Mas essas forças centrífugas são, como a gravitação, proporcionais à massa dos corpos. Não é possível, então, considerar o sistema de coordenadas como em repouso e as forças centrífugas como gravitacionais? A interpretação parecia óbvia, mas a mecânica clássica proibia isso.

Esse pequeno esboço indica como uma teoria da relatividade generalizada deve incluir as leis da gravitação, e a busca real da concepção justificou a esperança. Mas o caminho era mais difícil do que se esperava, porque contradizia a geometria euclidiana. Em outras palavras, as leis segundo as quais os corpos materiais são arranjados no espaço não concordam exatamente com as leis do espaço prescritas pela geometria euclidiana dos sólidos. É isso que significa a frase "uma deformação [warp] no espaço". Os conceitos fundamentais "reta", "plano", etc, consequentemente, perdem seu significado exato na física.

$\mathrm{Na}$ teoria da relatividade generalizada, a doutrina do espaço e do tempo, a cinemática, não é mais um dos fundamentos absolutos da física geral. Os estados geométricos dos corpos e as taxas dos relógios dependem, em primeiro lugar, de seus campos gravitacionais, que são novamente produzidos pelos sistemas materiais envolvidos.

Assim, a nova teoria da gravitação diverge amplamente da de Newton em relação ao seu princípio básico. Mas na aplicação prática os dois concordam tanto que tem sido difícil encontrar casos em que as diferenças reais possam ser sujeitas a observação. Até agora, apenas o seguinte foi sugerido: 
1: A distorção das órbitas elípticas dos planetas ao redor do sol (confirmada no caso do planeta Mercúrio).

2: O desvio dos raios de luz em um campo gravitacional (confirmado pela expedição inglesa do Eclipse Solar).

3. O deslocamento de linhas espectrais em direção à extremidade vermelha do espectro, no caso de luz vinda de estrelas de massa apreciável (ainda não confirmadas).

A grande atração da teoria é sua consistência lógica. Se alguma dedução dela se mostrar insustentável, ele deve desistir. Uma modificação disso parece impossível sem a destruição do todo.

Ninguém deve pensar que a grande criação de Newton pode ser derrubada em qualquer sentido real por essa ou por qualquer outra teoria. Suas idéias claras e amplas sempre manterão seu significado como a base sobre a qual nossas concepções modernas de física foram construídas.

Um comentário final. A descrição de mim e de minhas circunstâncias no The Times mostra uma divertida proeza de imaginação por parte do escritor. Por uma aplicação da teoria da relatividade ao gosto dos leitores, hoje na Alemanha sou chamado de homem de ciência alemão, e na Inglaterra sou representado como um judeu suíço. Se eu chegar a ser considerado um bete noire, as descrições serão invertidas, e eu me tornarei um judeu suíço para os alemães e um homem de ciência alemão para os ingleses! 


\section{$\mathfrak{T H E} \mathfrak{T I M E S}$}

\section{Todas as luzes curvando no céu}

Homens de Ciência mais ou menos Empolgados [Agog] com as Observações do Eclipse

Teoria de Einstein Triunfa

As estrelas não estão onde parecem estar ou onde são calculadas para estarem, mas ninguém precisa se preocupar

\section{Um Livro para 12 homens sábios}

Ninguém mais no mundo poderia entender a relatividade, disse Einstein quando seus editores a aceitaram para publicação

Telegrama Especial [Special Cable] para The New York Times. Londres, 9 de Novembro.

Esforços feitos para colocar em palavras inteligíveis para o público de não cientistas a Teoria de Einstein provada pela expedição do eclipse estão longe de terem sucesso. A nova teoria foi discutida em uma recente reunião da Royal Society e Royal Astronomical Society. Sir Joseph Thomson, presidente da Royal Society, declarou que não é possível colocar a teoria de Einstein em palavras realmente inteligíveis, mas ao mesmo tempo Thomson adicionou: 
"Os resultados das expedições do eclipse demonstrando que as luzes vindas de estrelas são curvadas ou defletidas de seu curso normal por outros corpos existentes agindo sobre ela e consequentemente a inferência de que a luz tem peso é uma contribuição muito importante às leis da gravidade que nos foram dadas desde que Newton estabeleceu seus princípios".

Thomson colocou que as diferenças entre as teorias de Newton e de Einstein são infinitesimais em um sentido popular [popular sense], e como elas são puramente matemáticas e podem ser expressadas apenas por termos estritamente científicos, é inútil se esforçar para detalhar essas diferenças para os homens na rua.

"O que é facilmente compreensível", ele continuou, "é que Einstein previu a deflexão da luz de estrelas quando passam o Sol, e o recente eclipse forneceu uma demonstração da exatidão [correctness] da predição".

"Sua segunda teoria sobre o movimento anômalo do planeta Mercúrio também foi verificado, mas sua terceira previsão, relacionada a certas linhas do Sol, está ainda indefinida".

Respondendo se as recentes descobertas significam uma anulação [reversal] das leis da gravidade como definidas por Newton, Sir Joseph disse que elas eram boas para os propósitos ordinários, mas em problemas altamente matemáticos as novas concepções de Einstein, através do qual o espaço deforma-se ou curva-se sobre certas circunstâncias, teriam que ser levadas em consideração.

Concepções muito diferentes que estão envolvidas nesta descoberta e a necessidade de levar em consideração a teoria de Einstein foram expressas por um membro da expedição, que apontou que ela significava, entre outras coisas, que duas linhas normalmente conhecidas como paralelas se encontram eventualmente, que um círculo não é realmente circular, que três ângulos de um triângulo não necessariamente fazem a soma total de dois ângulos retos.

"Já foi dito o suficiente para mostrar a importância da teoria de Einstein, mesmo se ela não pode ser claramente expressa em palavras," riu [laughed] este astrônomo.

Dr. W. J. S. Lockyer, outro astrônomo, disse:

"As descobertas, embora muito importantes, não afetaram nada, no entanto, nesta Terra. Elas não dizem respeito a seres humanos comuns; apenas astrônomos são afetados. Até agora tem sido entendido que a luz viajava em linha reta. Agora descobrimos que viaja em uma curva. Portanto, qualquer objeto, como uma estrela, não está necessariamente na direção em que parece estar astronomicamente."

"Isto é muito importante, claro. Para uma coisa, uma estrela pode estar a uma distância consideravelmente mais longe do que temos considerado até agora. Isto não afetará a navegação, mas significa que correções terão que ser feitas."

Um dos oradores na reunião da Royal Society sugeriu que Euclides foi nocauteado [knocked out]. Garotos em idade escolar não devem se alegrar prematuramente, pois é posto que Euclides estabeleceu o axioma de que linhas retas paralelas, se produzidas muito distantes, não se encontrariam. Ele não disse nada sobre linhas de luz.

Alguns cínicos sugerem que a teoria de Einstein é apenas uma versão científica do fenômeno bem conhecido de uma moeda em uma bacia de água que não está no local onde parece estar e perguntam qual é a novidade na refração da luz.

Albert Einstein é um cidadão suíço, com cerca de 50 anos de idade. Depois de ocupar uma posição como Professor de Física Matemática na Escola Politécnica de Zurique e depois disso na Universidade de Praga, ele foi eleito membro da 
William's Scientific Academy em Berlim, na eclosão da guerra. Dr. Einstein protestou contra o manifesto dos professores alemães aprovando a participação da Alemanha na guerra, e nesta conclusão ele acolheu [welcomed] a revolução. Ele tem vivido em Berlim a cerca de seis anos.
Quando ele submeteu seu último trabalho importante aos editores, advertiu [warned] que não havia mais de doze pessoas em todo o mundo que o entendessem, mas os editores assumiram o risco. 
